ASIAN BORDERLANDS

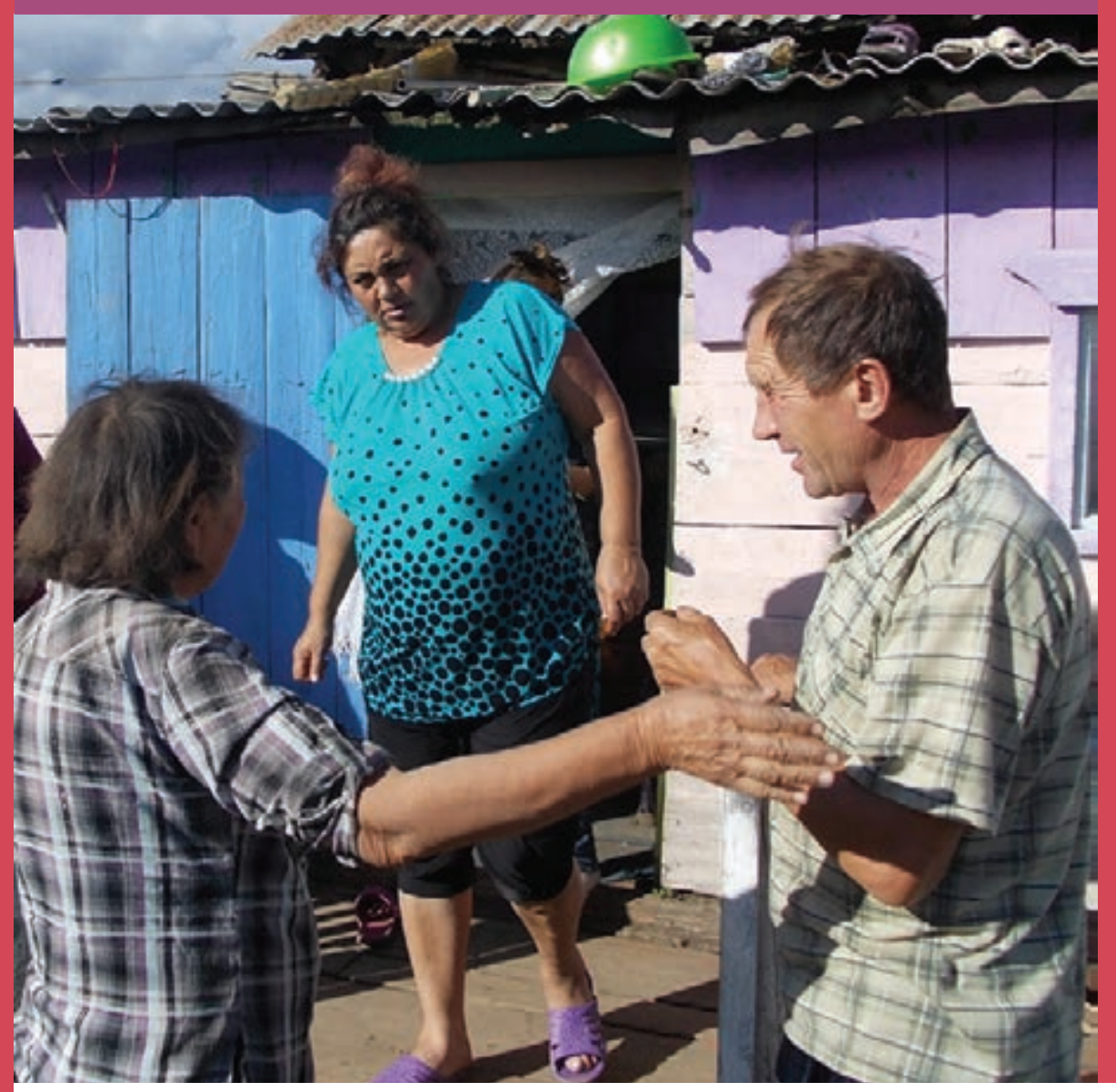

Edited by Caroline Humphrey

\title{
Trust and Mistrust in the Economies of the China-Russia Borderlands
}


Trust and Mistrust in the Economies of the China-Russia Borderlands 


\section{Asian Borderlands}

Asian Borderlands presents the latest research on borderlands in Asia as well as on the borderlands of Asia - the regions linking Asia with Africa, Europe and Oceania. Its approach is broad: it covers the entire range of the social sciences and humanities. The series explores the social, cultural, geographic, economic and historical dimensions of border-making by states, local communities and flows of goods, people and ideas. It considers territorial borderlands at various scales (national as well as supra- and sub-national) and in various forms (land borders, maritime borders), but also presents research on social borderlands resulting from border-making that may not be territorially fixed, for example linguistic or diasporic communities.

Series Editors

Tina Harris, University of Amsterdam

Willem van Schendel, University of Amsterdam

Editorial Board Members

Franck Billé, University of Cambridge

Duncan McDuie-Ra, University of New South Wales

Eric Tagliacozzo, Cornell University

Yuk Wah Chan, City University Hong Kong 


\title{
Trust and Mistrust in the Economies of the China-Russia Borderlands
}

\author{
Edited by \\ Caroline Humphrey
}


The publication of this book in Open Access has been made possible by a generous grant from the Isaac Newton Trust.

Cover illustration: Bargaining the sale of potato harvest near the Russia-Mongolia border, 2013 Photo: Nikolai Tsyrempilov

Cover design: Coördesign, Leiden

Lay-out: Crius Group, Hulshout

$$
\begin{array}{ll}
\text { ISBN } & 978 \text { 90 } 89649829 \\
\text { e-ISBN } & 978 \text { 90 } 48528981 \text { (pdf) } \\
\text { DOI } & 10.5117 / 9789089649829 \\
\text { NUR } & 761
\end{array}
$$

\section{(C) $(1) \Theta$}

Creative Commons License CC BY NC ND (http://creativecommons.org/licenses/by-nc-nd/3.o)

(a) The authors / Amsterdam University Press B.V., Amsterdam 2018

Some rights reserved. Without limiting the rights under copyright reserved above, any part of this book may be reproduced, stored in or introduced into a retrieval system, or transmitted, in any form or by any means (electronic, mechanical, photocopying, recording or otherwise). 


\section{Table of Contents}

Introduction

Trusting and Mistrusting Across Borders

Caroline Humphrey

Déjà vu of Distrust in the Sino-Russian Borderlands

Sayana Namsaraeva

Economies of Trust

Informality and the State in the Russian-Chinese borderland Tobias Holzlehner

Can Kinship Come to the Rescue?

Trust and Cooperation across the Border between China and Mongolia

Nasan Bayar

Betrayed by Trust

Inter-Korean Relations across Northeast Asian Borders

Hyun-Gwi Park

The Trade Town of Manzhouli

121

Trust Created and Undermined

Ivan Peshkov

Différances of Doverie

(Mis)trust and the Old Faith in the Russian Far East

Dominic Martin

Trust, Chance and Disappointment

Real Estate Business in Russia's Far East

Caroline Humphrey

Searching for Trust

Indigenous People in the Jade Business

Tatiana Safonova, István Sántha, and Pavel Sulyandziga 
The Emergence of Cross-Border Electronic Commerce

Creativity and Declining Trust

Natalia Ryzhova

Index

\section{List of Figures}

Figure 1 Map of north-eastern Russia-China borderland 8

Figure 2 The Coat of Arms and official flag of Kyakhta, Russia 43

Figure 3 Advertisement for job vacancies in Russian border cities, Manzhouli commercial press, $2013 \quad 57$

Figure 4 Map of the Russian Far East border region 70

$\begin{array}{lll}\text { Figure } 5 & \text { The border crossing at Hunchun-Kraskino } & 71\end{array}$

Figure 6 The 'Green Corner' market for used Japanese cars, $\begin{array}{ll}\text { Vladivostok } & 77\end{array}$

Figure 7 Trucks lining up to cross the border to transport coal from Mongolia to China, $2013 \quad 91$

Figure $8 \quad$ Buyan standing reflectively by an unused railway, 2013 97

$\begin{array}{lll}\text { Figure } 9 & \text { Chinese market in Ussuriisk, 2016 } & 118\end{array}$

Figure 10 'Patriotic' chairperson of the Vladivostok Old Believers Aleksandr Frolov (left) with Episcop German (centre) 159

Figure 11 A s"ezd ('congress') of Far Eastern Old Believers in the mid-199os held in Bolshoi Kamen'

Figure 12 A young couple negotiates a purchase in the 'Eastern Breeze' development, Vladivostok, $2013 \quad 190$

Figure 13 The 'Eastern Breeze' complex, Vladivostok, 2013 191

Figure 14 Chinese buyers scrupulously explore an old Chinese object put on sale at Sotheby's auction house in London, UK

Figure 15 Carl Fabergé's Easter egg, made predominantly of jade from a private collection of Viktor Vekselberg, the fourth richest person in Russia. The object is on display at special private museum in Saint-Petersburg, Russia

Figure 16 One of the Sunshine's operations. Guards reload raw jade to transport it across a river. Jade is on its way from mine to warehouse

Figure 17 Advertisement for a company offering help with on-line purchases in Manzhouli, China 

Figure 1 Map of north-eastern Russia-China borderland

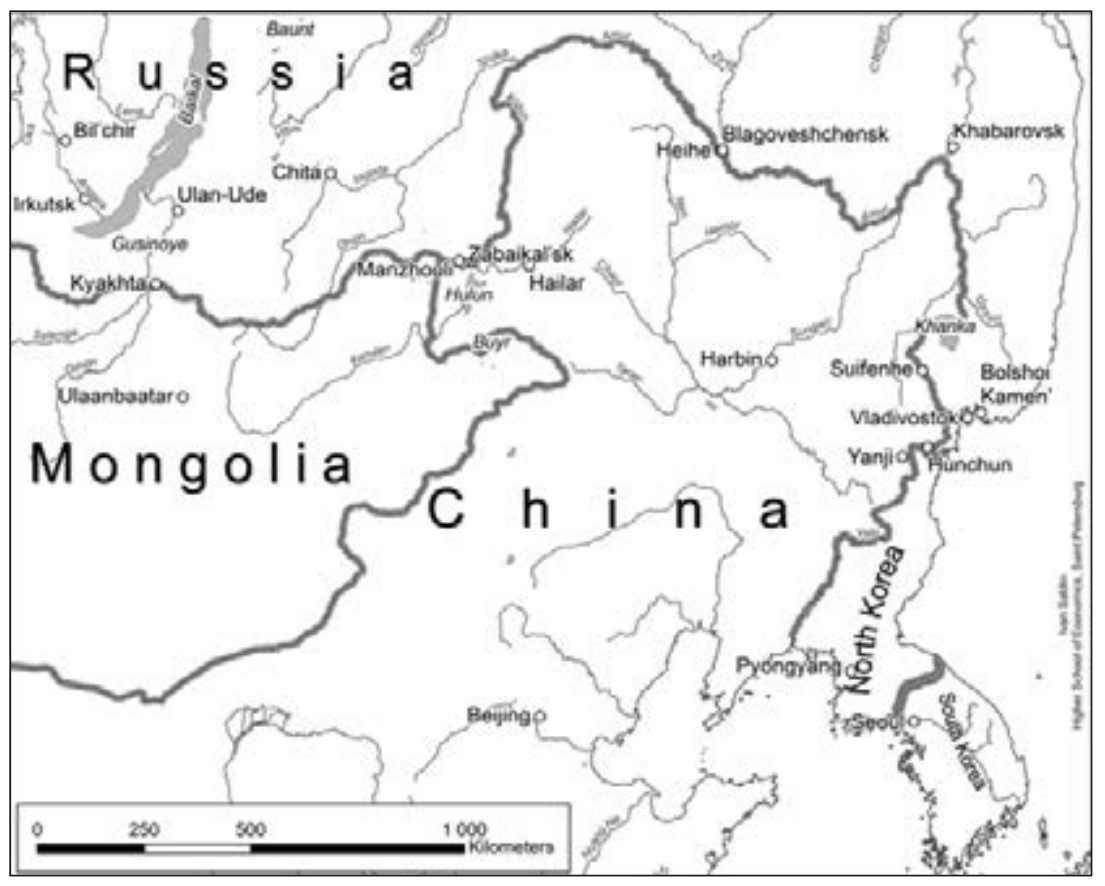




\title{
Introduction
}

\author{
Trusting and Mistrusting Across Borders
}

Caroline Humphrey

This book is a collection of essays based on recent fieldwork along the Northeast frontier between Russia and China, ${ }^{1}$ and it has two main aims that are closely interconnected. The first is to explore how trust and mistrust are negotiated in a situation beset with doubts and misunderstandings, in a border region where previously hostile states with very different histories, cultures, and languages face one another. The second is to suggest some ways in which these studies can contribute to understanding the import of trust and mistrust in small-scale economic activities. It should be added straight away that the book does not propose a theory of trust of its own to add to the numerous conceptualizations of this idea already available (Luhmann 1979; Gambetta 1988; Hosking 2010; Cook 2001; Hardin 2002; Dasgupta 1988; O'Neill 2002; Baier 2004; Hawley 2014). Rather, it provides anthropological ideas and ethnographic materials that will enable readers to explore and probe these models. What is new here is that, while the great majority of theories of trust assume that actors have a common background of values and expectations, this of course cannot be presupposed across a border like the one between Russia and China - nor, for that matter, inside either of these enormously complex countries. As several of the essays document, not only Russians and Chinese but also other peoples of the borderland (Mongolians, Koreans, Buryats, Evenki) have their own ways of enacting and expressing this idea. In short, this book addresses how trust and mistrust are deployed in both making and transcending boundaries.

Not agreeing about ways to create trust is one way to create mistrust. In fact, an unavoidable feature of these borders is the long historical legacy of mistrust between the peoples inhabiting them. Yet, somehow, a certain frontier economy continues to ebb and flow. One key argument made in this book is that both mistrust (as an initial stance towards others) and distrust (as a consequence of being let down) can be socially productive in

1 The essays in this book are the result of a three-year research project at the University of Cambridge funded by the RC UK ESRC 'Rising Powers' network: 'Where rising powers meet: China and Russia at their North Asian Border', 2013-16. We also gratefully acknowledge support for the project from the Isaac Newton Memorial Trust, Cambridge. 
a non-normative sense: they enable something else to happen, whether that be the emergence of mediators, processes of testing the untrusted other, or protests that may become political. We aim to illustrate some notable patterns found in this border region and to show how they are shaped - in perhaps unexpected ways - by their multifaceted environment: external economic exigencies, political structures, spatial-geographical circumstances, and the concepts people hold about one another and about trust.

Before introducing the chapters, let me first situate this book in relation to theories of trust and distrust. I am not the first to observe that the literature on this topic is vast and fragmented, with inflows from sociology, political science and theory, economics, psychology, history, philosophy, management and organization studies, and anthropology (for a survey, see Delhey and Newton 2003). It is therefore impossible to provide the (or a) theory of trust. Instead, I outline certain notable relevant contributions below, with the aim of describing the general terrain and some of the main questions that have been debated. Since this book is intended as a contribution to anthropology, the survey to follow, brief as it inevitably is, focuses on anthropology's distinctive approach to the topic of distrust/mistrust. Finally, this Introduction provides an indication of how the various chapters draw upon diverse strands of the literature on trust and make their own suggestions based on the empirical materials.

\section{Thinking about trust}

Political science, economic, and sociological theories have focussed far more on trust than on distrust. A common definition of trust that we broadly follow in this book is: an intention to accept uncertainty and risk based on a positive expectation of others (Dietz, Gillespie, and Chao 2010, 10). The plenitude of recent theories, however, differs greatly in focus and emphasis. Within a broad philosophical stream, one thread examines trust as a foundation of sociality and morality (Baier 2004), while another, exemplified by Onora O'Neill (2002), addresses the 'crisis of trust' in modern society (implicitly, the contemporary West) and asks how 'we' the public can best nurture and support it. Rather than seeing trust normatively in the context of rights and duties, a more psychological approach considers trust to be a matter of the attitude of individuals, depending on their personality, income, age, class, culture, etc. Sociologists, on the other hand, usually conceptualize trust as a property of certain social institutions, or argue more broadly that certain kinds of socio-cultural organization foster 
trusting attitudes (Putnam 2000). And political scientists debate the relation between trust and political forms, focussing in particular on democracy, 'good governance', greater perceived political freedom, public safety, and economic performance (Fukuyama 1995). Here, many authors see general public trust as a consequence, understood as the outcome of either a civic culture with high levels of shared customs, values, and beliefs that promote institutional and interpersonal trust (Putnam 1993; Hosking 2010), promotion by voluntary associations (Putnam 2000), or the public expectation that democratic institutions will function effectively (see discussion in Mishler and Rose 2005). Pierre Rosanvallon cuts into this debate by observing that conventional arguments about democracy conflate questions of legitimacy (abiding by the rules of democratic representation) with questions of trust (the assumption that politicians will act for the common good). But, he observes, not only do these two not always converge, but durable forms of distrust have been an inherent component of all democracies, however legitimate - and the people's distrust gives rise to positive attempts to impose controls on the political processes carried out in their name (Rosanvallon 2003, x-xi).

We take note of such theories and the generally held view that 'social trust $^{\prime 2}$ is good - a positive collective attribute that is essential for the lessening of social conflict, the growth of economies, the execution of contracts, a feeling of security, and reduction in the level of corruption. However, we note that many of the arguments that aim to demonstrate these points are bedevilled by cause-effect problems. For example, do people become more trusting as a result of participating in voluntary groups, or are such groups formed by people who already trust one another? Are businessmen less corrupt because there is more public trust, or is the level of trust higher because businessmen are less corrupt (Delhey and Newton 2003, 102)? The contributions in this book do not take part in causal theorizing about trust in the abstract, but instead address the conditions in which it exists - or fails to exist - in particular circumstances.

This book is concerned primarily (though not exclusively; see Martin, this volume), with trust in regard to economic activities, rather than political, religious, or intimate life. Here we note economist Partha Dasgupta's argument (1988) that social/public trust rests on the existence of a background agency, usually the state, that reliably enforces contracts and provides credible and impartial punishment for errant behaviour. We also take

2 The term 'social trust' normally refers to the degree to which people say they trust unknown others in a given society. 
account of anthropologist Ernest Gellner's proposal (1988) that the absence of such an agency means that people are likely to operate instead through strong interpersonal trust. ${ }^{3}$ It is fair to say that in neither Russia nor China can such an agency be relied upon by ordinary citizens to enforce the law impartially: erratic regulation plagues Russia in particular. These issues loom large in this book, especially in the chapters by Holzlehner, Santha and Safonova, and Ryzhova. And the issue of non-enforcement is, of course, compounded by the border, with its loopholes in jurisdiction and mutual uncertainty about the regulations on the other side.

Given the rapid shifts and economic turbulence of recent years, particularly the dramatic expansion of the Chinese economy, the zigzag of the Russian one, the mobility of exchange rates, and the greatly increased income polarization of the populations in both countries, economic actors are faced with great uncertainty and a bewildering plethora of factors to take into account. Here, surely, the classic formulation by Georg Simmel is relevant. Simmel describes trust ('confidence') as 'a hypothesis regarding future behaviour, a hypothesis certain enough to serve as a basis for practical conduct', and suggests that peoples, eras, and societies vary in the particular combination of knowledge and ignorance that is sufficient to generate trust (1950, 318-9). Following Simmel, Niklas Luhmann proposed an influential argument: trust, he suggests, has a functional value; it simplifies the perceived complexity of reality, enabling actors to behave as if the future were predictable and thus initiate activities (Luhmann 1979). Here one can see a certain similarity with approaches by economists, who likewise often conceptualize trust as a resource - an unusual one that does not get depleted as it is used, but rather tends to increase. In this interpretation, trust becomes an element in a rational strategy: agents work out subjective probabilities regarding the future actions of others and act accordingly. Trust is seen as a product of experience and it is is constantly updated in accordance with calculations about the probability of default or satisfactory completion of a given partner (Dasgupta 1988).

This book works at something of a tangent to these ideas, because it operates on a very different knowledge base. If the classic sociology is based on wide historical reading and the logic of action drawn therefrom, the economic theory is usually an exercise in working out the consequence of rational decision-making in invented situations, e.g., Prisoner's Dilemma

3 As Dasgupta further argues, these two points are closely connected: 'If your trust in the enforcement agency falters, you will not trust persons to fulfill their terms of an agreement and thus will not enter that agreement' (Dasgupta 1988, 50). 
questions. In contrast, the knowledge base of this book is personally observed ethnography, and the questions asked are not just about decisions (to transact or not, etc.), but instead concern the social, moral, and political dimensions of economic activity. This greatly widens the material to be taken into account, including, for example, the habitual ways of life of different cultures, political structures, inherited ideological shibboleths, indigenous trust-related concepts, stereotypes about others, and the local value systems that shape the motives people have for cooperating with others. Our contributors, who rely mainly on the disciplinary background of socio-cultural anthropology, therefore leave aside certain debates that have flourished elsewhere, such as the question of how - in the abstract - to exclude 'personal trust' (relationships between family, friends, and lovers) from the 'rationality' underlying economic theories. It has long been established in anthropology (Zelizer 2005) that economic calculation is thoroughly mixed up with personal relations, and the interesting question explored in the chapter by Park - is how people in particular circumstances draw their own frail boundaries while dealing with this mixture. This book thus follows distinctively anthropological approaches in resisting homogenous and a-temporal concepts of trust. While recognizing that there are important general points to be made, such as Luhmann's argument $(1979,25-9)$ that trust is achieved through reading the symbolic systems that interpret the world selectively and carry out the work of simplifying reality, rather than discussing such 'communication' in the abstract, the chapters show that trust in practice is a feeling that is only arrived at in particular socio-cultural settings - and maybe for not very long. And, furthermore, the signs may be deceptive or misunderstood. As Alberto Corsin Jimenez suggests (2011), trust relying on signals always goes hand-in-hand with masquerading, with movements in and out of opacity, and therefore always has mistrust as its shadow. If trust is the outcome of culturally specific performances, it will be doubly problematic in trans-border situations where there are radical differences in social strategies and ideas about what should be revealed and what hidden.

\section{Thinking about distrust}

In fact, it is distrust rather than trust that is most evident across the ChinaRussia-Mongolia-Korea borders, and yet some of the same questions arise. Is this distrust a matter of dealing with unfamiliarity and problems of communication - for these populations were essentially cut off from one 
another for decades during high socialism and have only recently made some relatively limited contacts? Or is it a remnant of earlier state ideological battles? Is it simply a widely present feature of socio-political relations in these societies? Or is it some mixture of these? If one looks at the sociological literature on distrust for guidance (this being considerably smaller than that on trust), one finds that general works on the topic share one feature with trust theory: the preponderance of discussion in the abstract. Arriving at a theory of 'distrust' as a human propensity through abstracting from particular cases also means leaving behind much of the rich material that is the basis of anthropology. Nevertheless, we have found much value in the debates in this literature. One concerns the relation between trust and distrust. Much of the trust literature rarely addresses distrust in its own right, but tends to envisage it as a lack - a simple absence of trust, or the opposite of trust. However, Diego Gambetta's seminal study $(1988,218)$ suggests the fruitful idea that we should instead be considering a scale, in which various forms of trust hover between 'blind trust' at one end and 'outright distrust' at the other. Trust thus appears as a variable 'threshold point' in a given context, rather than as an absolute. Then there are the sociological and economic approaches, also discussed by Gambetta, that point out that distrust need not be seen as necessarily in opposition to trust, but can instead be its functional equivalent. Luhmann (1979), for example, maintained that in certain contexts a suspicious attitude could also mobilize a prediction of the future, while later Russell Hardin (2004) and Karen Cook, Hardin, and Margaret Levi (2005) argue that mistrust can be a positive spur to action based on the constant attempt to guess the intentions and capacities of others. This line of thought led to the idea that distrust also can be understood as a range, varying from 'hard' (paralysing) distrust to 'prudent' distrust that allows for certain interactions, an idea that is taken up in the chapter by Namsaraeva in this volume.

By contrast, the anthropology of distrust, which has a long history, ${ }^{4}$ has examined it as emergent within a concatenation of moral ideas and practical

4 A classic study is Banfield's The Moral Basis of a Backward Society (1956), which describes the inhabitants of a South Italian village as convinced that success can only come at the expense of others. Prey to suspiciousness, lying, gossip, and betrayal of everyone outside the close family, they are mired in what Banfield calls 'amoral familism', which ties them into a socially and economically paralyzing mistrust. Another well-known work dealing with distrust is Colin Turnbull's study of the Ik (1972), which depicts an even more toxic endemic mutual enmity. Turnbull was for a long time disbelieved, but his ethnography has been confirmed in many ways by Christian Gade, Rane Willerslev, and Lotte Meinert, who document the faltering 'half-trust', laced with concealed enmity, that is invoked by Ik farmers in the face of fluctuating violence 
tactics. This theme has recently received a burst of new interest in the form of studies of subjectivities associated with mistrust, deception, uncertainty, and opacity. This is the arena of diverse misgivings that pervades even a provisionally given trust - for we can never know with certainty what is on another's mind. Joel Robbins (2008) has pointed out - admittedly amid controversy (the 'opacity of mind' debate) - that certain Pacific Island cultures assume that it is difficult, if not impossible, to read the minds of others. In other words, they question the presumed universal human interest in delving into others' thoughts and motivations. With such withdrawal from gauging other's future actions, there may be little value placed on trust and little investment in prediction and planning in such societies. Our case is something like the opposite of this. In both China and Russia, a consequence of decades of Party grandiloquence that is clearly contradicted by the evidence of one's eyes has been not only popular cynicism and lack of trust in the government, but also indeed the desire to attempt to penetrate to other people's true thoughts, to 'tear off the masks' (Fitzpatrick 2005). In China, people invoke the expression biao li buyi ('the outside and the inside are not the same') as a criticism of others' subterfuges (Steinmüller 2016, 2). But discourses of truth and sincerity of course pre-dated the opacity of the socialist and post-socialist governments. They can be seen as age old cultural-philosophical resources for reflection by Russian, Mongolian, and Chinese people.

Reflection not only on the motives of others but also on oneself as a person who is also likely to be acting in an untrustworthy way. As one Chinese microblog concerning a murky affair reads: 'Isn't the taste of keeping your conscience in the dark while acting like a dog hard to take?' (quoted in Latham 2016, 163). In both countries, the evaporation of high socialist ideals - which, it is generally thought, earlier generations believed in - was followed by a dominant discourse of moral decline, in which people situate themselves, one way or another, in an unprincipled world (Osburg 2016, 51). Mistrust, and the difficulty of trusting or being trustworthy, are part of this.

In the recent literature, anthropologists have questioned the previous consensus that trust is unequivocally a virtue and distrust is automatically

from Turkana raider herders and the 'double, tricky relationship' involved when people are dependent on others more powerful than themselves $(2015,417)$. On a different continent, Olivier Allard describes the mixture of hope and anxiety that pervades Warao interactions with national bureaucrats via documents. Warao villagers thoroughly distrust officials demanding demographic data, and yet Allard shows that they themselves make creative use of unreliable documents, such as registration forms, to claim various kinds of state support, with the accompanying rhetoric 'we the Warao are helpless...' (Allard 2012). 
a harmful thing. A collection of essays (Allard, Carey and Renault 2016) points to thinkers and whole bodies of social opinion according to which mistrust can, on the contrary, be a civic and political virtue: suspicious alertness provides protection from dangers, and vigilance can be a public duty in the exercise of controlling power. In such views, trustfulness - i.e., the absence of mistrust - looks naïve. These authors build on Luhmann's argument that a mistrustful attitude, because it does not simplify choices like trusting, but on the contrary keeps the difficult complexity of the real world in view, may lead not to paralysis but to practical, useful knowledge in situations of uncertainty. Indeed, 'as a strategy, mistrust is an ability, an art with its virtuosos, and can lead to a systematization of behaviour or steps taken towards the real' (Allard, Carey, and Renault 2016, 2, my translation). A further notable contribution has been made by Matthew Carey's recently published Mistrust:An Ethnographic Theory. ${ }^{5}$ Carey's study is based on fieldwork in the Moroccan High Atlas, where peasant society is beset by chronic suspiciousness, with communicative strategies based on obfuscation and dissembling, and frequent accusations of deceit and betrayal. Here there is an ineradicable mistrust, not just of outsiders but also enveloping the very closest people, because the villagers feel that no one can be known entirely. Thus, trust and mistrust appear in Carey's work not as abstract values but as cultural-moral stances towards life and the self. Trusting, Carey observes, implies a willingness to place oneself in a degree of dependency on the person trusted, but at the same time it can be a way of managing others, because trusting requires compliance from those we trust (lest it be lost forever). On the other hand, the Moroccan stance of mistrust is different: it is part of a philosophy of rugged autonomy and moral equality that assumes both oneself and other people to be free and fundamentally uncontrollable. However, these two stances are not mutually exclusive; in practice, each implies its shadow: 'where people assume others can be known and trusted they also know that this is not always the case, and where they assume others are inscrutable they are also aware that some people are less unknowable than others' (Carey 2017, 14-15). We have found no society in the northeast Asian borderlands that has quite the intensity of internal mistrust of the Moroccan High Atlas, and in north Asia hierarchical relations of one kind or another - rather than 'rugged autonomy and moral equality' - are prevalent. Yet Carey's observations

5 Carey (2017) distinguishes between 'distrust' and 'mistrust', observing that while the two are very close in meaning, distrust is likely to be based on a specific past experience, while mistrust describes a general sense of unreliability. 
about the light and shade interweaving trust and mistrust are relevant to many of the chapters (especially Humphrey, Park, Bayar, and Namsaraeva).

\section{Trade in a politically fragmented borderland}

There is a gap in studies of northeast Asia that this volume hopes to repair. Relatively few anthropological studies address trust and distrust in economic interactions across international borders, and none in English, as far as we know, have dealt with this theme in relation to the China-RussiaMongolia border. While recent studies by historians and anthropologists (Van Schendel and Itty 2005; Tagliacozzo 2005; Reeves 2012; Billé, Delaplace, and Humphrey 2012; and Reeves 2014 to name but a few) have investigated border sovereignty, migration, and subjectivities, and have interrogated earlier assumptions about the politics of states at Eurasian international borders, the question of trust, though mentioned, is not addressed centrally. Another literature does compare the levels and dimensions of 'social trust' within post-socialist societies using diverse models, but does not look at interactions between these countries (Mishler and Rose 2001; Delhey and Newton 2003). Yet another body of literature focuses on social trust - and its absence - in Russia and China, but again focuses on each country separately (e.g. for Russia: Oleinik 2005; Mishler and Rose 2005; Shlapentokh 2007; Mühlfried 2014; and for China: Weiying and Rongzhu 2002; Wang and Liu 2002). Thus, trust/mistrust and cross-border economies in northeast Asia remain to be studied together.

It would be natural to expect a volume on trust in economic practices to focus on trade and traders. While Tobias Holzlehner's chapter is largely devoted to illegal trade in Vladivostok, the book as a whole takes a broad compass and draws attention to other economic activities in the borderlands, such as mining, real estate speculation, construction, migrant labour, long-distance trucking, sex work, wildlife poaching, online mediation, and urban marketplaces. Nevertheless, trade broadly understood - both small- and large-scale - is central to the cross-border economy and is part of all of the above-mentioned activities. So this introduction provides an overview to fill the ethnographic gap concerning the various kinds of trade along the length of this border, outlining various forms of legal, a-legal, and illegal trade and noting how problems of trust are managed in different ways within them. The landed sites of cross-border trade differ from Vladivostok with its complex and unique maritime situation. And yet, despite geographical variations along the frontier, I argue that it is the political formation of 
the international borders and their changing regulations that have shaped the distinctive patterns of trade and their developments over time. What follows will not be quantitative economic data (the difficulty of producing a statistics-based account is discussed in Ryzhova $\left.2013^{6}\right)$, but will instead focus on the social dimensions of trade, i.e. the relatively distinct kinds of traders, their networks, and their practices. The forms of trust/distrust found in trading can be seen as something like a repertoire, which can be taken up and indeed used in different contexts, such as business investment or labour management.

Because the border was sealed for decades between the late 1950s and the early 1990s, during which the only 'trade' consisted of official state-tostate transfers, earlier mercantile and trading traditions fell into disuse. This was less marked in China than in Russia, since in the latter state socialism was older and more deeply embedded and had brought with it a strongly negative attitude toward 'speculation' (as private trade was called). This national difference is reflected in what happened after the 199os, when crossing points were opened and trading started up. The Chinese government strongly promoted small-scale private trade ventures across its borders and simultaneously encouraged provincial border administrations to make international agreements on their own account (see Namsaraeva, this volume). This Chinese state-led liberalization made rapid inroads into the demoralized, de-industrialized wasteland of what Hyun-Gwi Park has called the 'state-neglected liberalization' of Siberia and the Russian Far East $(2016,377)$. The result was a sharp economic imbalance, in which the vast majority of goods, especially consumption items, came from China, and the purchasers came from Russia. Compounding this situation was Russia's long historical obsession with sovereignty (Sakwa 2011) and its fear of an influx of Chinese population and influence, anxieties that have scarcely slackened in recent years. A consequence was that Russia neglected local economic prosperity in favour of the paramount importance of border security. Around 2010, Russia closed numerous border-crossing points along its borders with Mongolia and China. Strict controls were placed on Chinese migration into Russia, with a panoply of visa and work quota requirements, and after 2007 'foreign' citizens (affecting mainly the Chinese) were debarred from the

6 Ryzhova $(2013,250)$ documents large inconsistencies between the official figures for imports and exports given by Russian and Chinese sources. Each side gives a large figure in US dollars for their exports and a smaller one for their imports. The vast amount of 'illegal' trade over this border is unaccounted for in these figures. Other sources, such as the customs' services, are also unreliable. 
right to trade in Russian marketplaces. The reasons for, and consequences of, this security mania, and its expression in Russian popular mistrust of the border city of Manzhouli and distrust of 'Chinese traders', are the subject of Ivan Peshkov's chapter in this book.

But what about actual trade practices? With few crossing points open for trade along the thousands of miles of the Sino-Russian border, ${ }^{7}$ the result is bottlenecks, queues, and rich opportunities for rent taking by border officials. The impasse at checkpoints applies primarily to goods travelling overland from China to Russia. ${ }^{8}$ This consists of an enormous variety of clothing, footwear, electrical/digital items, agricultural products, machinery, textiles, furniture, and home goods. From around 2010 the problem of bottlenecks has become ever more pronounced, especially at Manzhouli-Zabaikal'sk. For one thing, transport infrastructure cannot cope with the increased flow: the Trans-Siberian Railway, though improved in some sectors, is unable to manage the increased number of wagons, and the Russian roads are slow and rough. For another, the process of inspection, customs, etc., at key crossing-points is extraordinarily inquisitorial and expensive. Up to 500 wagons may wait at Zabaikal'sk (the Russian border town adjacent to Manzhouli) waiting for customs clearance, and it can take up to six months for one to pass through (Namsaraeva 2014, 119). The China-Mongolia border is far easier to cross, for both goods and people. But the Mongolia-Russia border also has many hindrances, notably the small number of official crossing points, high tariffs, the time limitation on Mongolian citizens' visits to Russia, and the special visa required for trading. ${ }^{9}$ All of this shapes the patterns of overland trade in the region. If we interpret 'trade' broadly and include smuggling and poaching, it is possible to delineate five notable variants, which I briefly describe below (though the material being patchy along this lengthy border, I have only been able to mention some; no doubt others exist).

The first type involves long-distance routes and large-scale container consignments by train or road-transport that are organized by major companies, usually based in metropolitan cities. These companies, both

7 Road and rail crossing points differ. The Zabaikal'sk-Manzhouli crossing is the only one where both coincide; it therefore has the greatest flow of goods and people, and the most problematic bottleneck.

8 China has smoothed the path of its imports from Russia, most of which are bulk materials such as oil, gas, machinery, coal, and timber.

9 Since November 2014, the regulations for citizens of Mongolia have been lightened; there is now a visa-free 'tourist' border-crossing regime, but with a limit of 30 days and no permission to trade. 
Russian and Chinese, usually work through brokers and/or 'expeditors' to make the necessary confidential arrangements with the border officials to get their goods through. Operations at this scale are regarded with a mixture of awe and dislike by small traders. One day Sayana Namsaraeva saw an important and haughty-looking Russian woman sweep through the Manzhouli customs area, accompanied by two well-dressed, obsequious Chinese men. 'She's a top customs broker,' people whispered, 'and those guys will do everything for her, money, hotels, cars, restaurants... because she'll help them get their goods passed.' Looking at the scene, a small trader commented, 'Here every meter on the border is bought', and he implied that the Chinese were likely to be part of a mafia-type criminal network with a long partnership with this woman, who could be trusted because she had demonstrated her worth to them over the years. However, using brokers may not improve matters much: after all, they themselves add another cost to the notoriously high bribes taken by customs, not to mention the barriers that can be erected by security agencies, sanitary inspection, certification of the goods, warehouse payments, etc. Recently, the broker function has been officialized, so alongside a number of rapacious private firms there is now the Customs Brokerage Centre in Zaibaikal'sk, which charges up to 10 percent of the value of the goods. This brief account provides some regional contextualization for several of the chapters (Bayar, Ryzhova, Holzlehner, and Namsaraeva), which describe brokers and mediators and the need for them to concoct some temporary, time-specific, and fragile two-way trust between mutually suspicious actors who nevertheless have a strong interest in making a deal.

The Manzhouli-Zabaikal'sk crossing has the reputation of a 'hell' for companies on both sides (Namsaraeva 2014, 119). Viewing the border as a particularly vexatious 'complication' in the lengthy trajectory between origin and destination, a top-end Russian businessman exporting to China tends to need extremely high-level contacts in Moscow, ${ }^{10}$ and even then he may well complain of sometimes having to fly down and sort out the Brokerage Centre personally (ibid., 120). Meanwhile, his Chinese counterparts have been increasingly washing their hands of the whole situation and switching to routes via Kazakhstan, where the border procedure is relatively simple. Despite being a far longer route via a third country, Chinese goods arrive in central Siberia ten days faster this way. In short, large-scale

10 An example is Igor Chaika, son of the General Procurator of Russia, who discussed his problems setting up an export company for the Chinese market in foodstuffs. http://www.rbc. ru/interview/business/o1/o3/2017/58b6e1789a794726962d2c8b. 
trade is beginning to abandon the northeast Asian border crossing routes. This entire situation has deleterious effects on the Siberian and Far East economy, as it raises prices on many items that appear in such a circuitous manner. It also affects the practices of other kinds of traders.

The general operation of 'shuttle-trade' has been well described in the regional literature, yet the constraints and affordances of particular traders remain little known in sources in English. I briefly describe the example of 'Darima', a Russia-based Buryat trader whom Sayana Namsaraeva and I met in Manzhouli in 2013. ${ }^{11}$ Her business is local, consisting of receiving orders for consumption goods from village shops or boutiques in shopping-malls in Buryatia, assembling a team of carriers, buying the goods in Manzhouli, and taking them back to Russia for distribution to the clients. Darima and her team often make the trip back and forth several times a day. The need for a team comes from the Russian border regulation that individual travelers may only carry up to $35 \mathrm{~kg}$ of luggage $\mathrm{e}^{12}$ without paying exorbitant customs duties, while low wholesale prices in China are given only for bulk consignments and each shuttle firm is in competition with the others to offer low prices to the Russian consumers. The entire business rests on trust: first, Darima has to trust her carriers, who are almost all women ('women are more reliable, careful, and cooperative') and who call themselves 'camels' in distant reference to the trade caravans that used to wind their way from China to Russia in the past. Darima relies on her camels not to damage, steal, or replace the goods with inferior items, and to be able to physically do the heavy lifting. The team has to travel together in a cramped minibus, eat together, sleep together, and negotiate with the Chinese sellers, so this trust rests on repeated, intimate, and arduous experience; there is no way Darima would take on someone who phoned out of the blue and asked to join her team. Second, she has to trust the customs officer, to whom she has paid some 5,000 rubles per box in advance and with whom she has made a private arrangement to wave her consignment through. The whole situation is fraught with anxiety, for both the camels and the customs officer have to 'play their part' in case an inspector appears on the scene. This is why before crossing the border the boxes of goods have to be opened and redistributed in packages to each camel, 'as if' they might be an individual's luggage. Darima is in charge of this operation, and she instructs each carrier to learn by heart that she has 7 shirts, 9 pairs of trainers, 22 boxes of nappies, 3 quilts,

11 See Holzlehner, this volume, for the analogous situation in Vladivostok and Ryzhova (2013, 246-78) for a detailed description of the shuttle-trade at Blagoveshchensk-Heihe.

12 This weight limit is changed from time to time, with immediate effect on the shuttle traders. 
etc.; she told us how she had been rudely criticized by the customs officer when an inept camel failed in the performance of 'these goods are mine' and forgot what she had in 'her' luggage. The customs officer meanwhile has to perform the role of strict inspector, in the knowledge that an anti-corruption drive is (selectively) under way in Russia. He needs to remember that all boxes with a pink ribbon belong to Darima, and to make sure that he is on duty in a quiet area at the time promised. Following the transit, the bundles have to be re-packed as if newly acquired, checked and counted, and then sent on to the shop-owner clients. Finally, Darima has to trust the person who placed the order. We witnessed the moment when she received a phone call that a previous consignment had arrived in Chita. Only following this would she be paid for that trip. Darima does not have a large reserve; only after receiving confirmation of the money for the previous venture does she pay the customs officer for the next trip and her camels for the one they have just accomplished. Darima knows the border like the back of her hand, each customs man, 'each dog, each cat', as she said. Quite often 'her' customs man will ask her to get something for him from China on the side, either as a friendly present or as part of the payment for his service.

The wider politics of the border, notably the freezing out of Chinese traders, means that virtually all of the shuttle traders are Russian citizens (though some are 'place men' to provide an official face for a business that is in fact Chinese-owned). It is rare for them to speak Chinese, although among the few who do some have made substantial profits, gradually branched out, created more substantial logistics or transport companies, and rose into the category of large, long-distance traders mentioned earlier. Meanwhile, the border regime has given rise to another, even humbler type of trade: the more entrepreneurial cash-strapped inhabitants of the border region, very often Mongols, who have taken to ad hoc, unsanctioned vending in Russia in large numbers. They operate as individuals, but are linked changeably to shops and marketplaces, often in out-of-the-way towns and villages. Unlike the shuttle traders who have settled routines and a certain esprit de corps despite the competition between them, these people do not see themselves as 'traders', but instead dip in and out of business; they undercut prices by their flexibility, their willingness to travel and substitute for one another, and their 'unnatural' (as the Russians see it) ability to work hard, live cheaply, and withstand hardship. The Mongols benefit from the fact that their easier southern border means that Chinese goods are lower priced in their country than in Russia, and from their ability to negotiate endlessly complicated loan arrangements with friends and relatives. But their trading in Russia is constrained by regulations, especially the short time 
and prohibition on (legally) engaging in business without a special visa. This means, as one man explained to me, that their strategy is the fastest possible sale of the maximum number of goods at rock-bottom prices, and then a quick getaway with the small profit. Travelling back and forth, the same people carry information and samples of Russian goods that are in demand in Russia to the Chinese workshops making fakes that are based in Mongolia or in Inner Mongolia at Erlian. They then take the 'genuine Russian products' back to sell throughout Siberia (Sodnompilova 2010:14): this is an example of the metamorphosis of material at borders that resonates with the transformation of stones into precious 'jade' discussed in the chapter by Safonova and Santha. These traders do not trust one another, according to local accounts. As one Mongol vendor said: 'We would never pool money and allow just one of us to go to Manzhouli to buy the goods - because we don't trust one another. The Kyrgyz can "raise" around 20,00o rubles in one day [for such a trip], but that's unthinkable for us' (Sodnompilova 2010, 18).

It is these Kyrgyz traders, my next category, who have taken advantage of the ousting of the Chinese to dominate the market places and malls throughout Eastern Siberia and towns in the Far East. During the 1990searly 2000s, the 'Chinese markets' in cities like Irkutsk were regarded by municipal authorities as 'crime-promoting spaces' and by the townsfolk as useful but alien closed enclaves. And indeed, the Chinese traders lived and sheltered on site, rarely venturing into the city for fear of xenophobic attacks. Several municipalities then moved these 'Chinese markets' into places on the outskirts. But meanwhile, as the Chinese themselves melted away, the Kyrgyz and other Central Asians took over, first setting up their own ethnically distinct 'trading rows' of stalls and later separate Kyrgyz-named malls within the new, now more 'open' and publicly acceptable market areas (Horie and Grigorichev 2016). They could succeed because, as citizens of former Soviet countries, they were not classed as 'foreigners' and were given privileges that allowed them easily to obtain trading permits or Russian citizenship. With better knowledge of the Russian language and culture than the Chinese, they could also better counter hostile attitudes. Further, they benefitted economically from the previously mentioned switch of Chinese wholesale consignments to routes in Central Asia. Purchasing goods in Central Asian border markets, or even from Moscow or Novosibirsk, Kyrgyz traders could still sell more cheaply in Siberian towns than the shuttle traders who have to cope with the exigencies of Zabaikal'sk-Manzhouli. Some former shuttle traders in Ulan-Ude told us that they had given up on the trek across the border to China and now preferred to travel to Irkutsk to buy wholesale from the Kyrgyz. 
In many ways, the Kyrgyz resemble the Afghan traders discussed by Magnus Marsden in his book Trading Worlds (2016), first of all because of the social institutions they have in place that ensure trust. The Kyrgyz operate in small teams of kinsfolk. The great distances of their routes require each team to place a trusted person in cities or markets that are far apart. Yet in this situation, merely being a relative is not enough. Cross-border operations require facility in calculating exchange rates, reliable accounting of stock and credit, the accurate communication of changing conditions, and so forth - in other words, being trusted goes hand-in-hand with the need to develop the skills that enable you to actually perform the trading tasks. Furthermore, as Marsden writes, such traders need to be internationally oriented actors, akin to diplomats $(2016,21)$, for they also need to negotiate the potential hostility of the local populations.

In Eastern Siberia both Russians and Buryats see the Kyrgyz traders as competitors, endowed with their own somehow unfair and alien cohesiveness. An example is 'the sharia bank', which is said to enable the Kyrgyz to transfer money by purely oral agreements, usually by mobile phone. It is not clear that any such bank exists, and it may be a figment of the imagination of the locals; yet, the expression stands for arrangements whereby Kyrgyz and other Central Asian traders can make purchases and payments across a border without actually transferring money, through accounts held in balance with a trusted person on the other side. The system appears to be similar to the informal 'flying banks' by which the Chinese repatriate their profits across the border, a practice that has been lessened but not eradicated by the change in Russian law in 2003 allowing officially registered banks to operate in both yuan and rubles (Ryzhova 2013, 270). The practice among Central Asians of eschewing written contracts and doing business through a handshake ( $p o$ ruku) works particularly to their advantage in China. As a director of a Siberian market said, 'Often the Chinese will advance a valuable commodity to them to sell, requiring payment only later, which they would not do for a Russian entrepreneur' (Varnavskii 2010, 48). Such preferential person-to-person trust, combined with their own international backing, enables the Kyrgyz traders to accommodate to the circling sharks (mediators, brokers, expediters) that take pickings from less adept businesses. Traders and migrant workers put pressure on cheating mediators who come from the same community as themselves by means of shaming, gossip, and ostracism from their families back home (Urinboyev and Polese 2016, 198-201). This point is illustrated in Ryzhova's chapter on the Internet trade between Russia and China. Here, to a great extent because of the language problem (i.e. understanding Chinese websites), 
Russian purchasers have been obliged to use local intermediaries. While they had to trust these brokers, it was meanwhile not in the latter's interest to default - and Ryzhova describes how an initial experimental trust placed in such firms run by relatives and friends could gradually transform into a firmer trust based on experience.

The Kyrgyz trading teams, composed almost entirely of close kin, are usually managed by a family elder, who may well operate at a distance and remain in Kyrgyzia. These trust ties therefore rest on complex concatenations of affect, obligation, status, and respect over time and generations. The actors stand to lose far more than their stake in a particular deal. For example, Sayana Namsaraeva and I met a young Kyrgyz girl, sitting all alone in her stall in the market in Ulan-Ude, who said the business was owned by her maternal uncles. She worked for them unpaid, being provided with only minimal food and a sleeping spot, because the agreement was that sometime in the future they would provide her dowry, which would enable her to make a good marriage. As for the relations between Kyrgyz businesses, they try to avoid competition and help one another as zemlyaki ('people from one place'); they trade next to one another in markets, socialize together, pray together, and bury their dead in a separate cemetery. Varnavskii's study of the Kyrgyz traders in Krasnokamensk indicates that Islam is even more important to them than ethnicity and is an essential part of the moral understanding that underpins their mutual trust. Explaining who was sent to China to buy the goods on behalf of the others who had clubbed together to provide the money, a trader said, 'It doesn't have to be a Kyrgyz. Could be a Kyrgyz, or a Tajik or an Uzbek. What is important is that he must be a Muslim!' (Varnavskii 2010, 49).

We see from the case of the Kyrgyz that their success rests in part on competence but much more on the depth of the trust they call upon and perform for one another, which is embedded in a web of long-standing social relations and moral accountability. This has the effect of enfolding their internal economic transactions within a variety of other relations, of kinship, national identity, place of origin, and religion. This example is particularly relevant to the chapters by Bayar and Park, which discuss Mongolian and Korean attempts to establish trust for economic purposes via the use of kinship. Both papers are instructive, for they show that, contrary to the suppositions of authors (e.g., Fukuyama 1995; Putnam 200o) who assume that 'traditional' kin obligations are the very root of trust, even the very closest of such ties have to be confirmed by explicit guarantees concerning a given venture (the Mongolian case), and further, the two sides of an agreement may have different understandings of the kinship 
relation in question (the Korean case). Such detailed analysis is important, because it is easy to be misled by actors' rhetoric about their wonderfully unbreakable kin ties, while their practice reveals subtle calculations not only about the future behaviour of kin but also about the economy in which everyone has to sink or swim.

Finally, I should briefly mention the traders who specialize in illegal practices, actors who are central to the chapter by Tobias Holzlehner. Trade is 'illegal' either because the goods themselves are forbidden in a given country, or because the complex, multiple certification necessary to acquire, possess, transport, or sell them has not been obtained. As customs' websites show, goods are also counted as kontrabanda in Russia if they are legal but undeclared at customs, declared under false pretences (counterfeits), or declared in wrong amounts. An immense variety of consignments fall into these categories. The 'shape' of trade networks is determined by the nature of the goods and the regulations to which they are subject. Difficultto-obtain products without an export license, such as the Siberian-mined stones smuggled into China as 'jade' (Safonova and Santha, this volume), poached wildlife items like tiger parts or bear's paws (Holzlehner, this volume), or the transport of illegally mined gold, require the elaboration of long secretive networks that link hunters, miners, etc., in the depths of the taiga to purchasers in China via brokers. Such specialized networks often have their own obscure routes that bypass the official crossing points, including 'trans-shipping' at sea, whereby cargo, fuel, crew, or fish catches can be moved from one vessel to another out of sight of the authorities. ${ }^{13}$ However, for many common items that circulate illegally in Russia (currency, drugs, untested medicines, weapons, or fake branded products) the field is more open and the shape of the network may be less attenuated. In fact, any of the previously mentioned kinds of traders may be tempted to take part - for example, the Mongols' participation in the production of fake goods mentioned earlier.

Yet all illegal operations ratchet up the intensity of trust needed, as the penalties are severe (including the death penalty, for drug trafficking in China). Let me return to the shuttle trader Darima, for an example, and the ambivalent 'evidence' that such cases arouse. Darima, it is said, was recently caught at Zabaikal'sk transporting illegal drugs (har tamhi in Buryat, an expression that might cover anything from heroin to newly invented chemical drugs). She was jailed, and had to pay a huge sum to extricate herself

13 https://www.chinadialogue.net/article/show/single/en/9653-Transshipping-spurs-trade -in-illegal-fishing-led-by-Russia. 
from the situation, equivalent to 3 or 4 years of her profits. When she got out of prison she was unable to return to the shuttle trade, as everyone knew she had been arrested. Because her trust-relation with customs had been broken, no one would have confidence in her any longer. She soon quit the region and moved far away to Novosibirsk. But she maintains that she was innocent: she had not carried drugs, and she attributes the accusation to having offended a customs officer, either by not paying him what he asked for, or by cheating him about the value of her goods, which risked his professional position. ${ }^{14}$ The episode remains unclear - like much that happens on this border - just as whom, exactly, Darima had to pay to be released from prison remains obscure. Yet despite the cloudiness that surrounds this case, it is further evidence that trust is additive in terms of action. As Matthew Carey points out, if I trust you to deliver the goods on a given date, then I can rent storage space, arrange meetings with potential buyers, and so forth (Carey 2017, 9). Conversely, loss of trust (which is by no means the same as canny mistrust) is subtractive: if Darima has lost the trust of her customs officer partner, clients will no longer engage her team and her entire business unravels.

Darima's unfortunate case also shows, as Ryzhova argues for Blagoveshchensk-Heihe $(2013,275)$, that the networks involved in illicit trade are not uniform webs but are composed of people carrying out different and unequally potent functions. ${ }^{15}$ The client ordering the goods, the supplier, buyer, transporter, broker, 'place man', receiver of the contraband goods, and the various licensers, who may operate according to the rules or take a substantial cut, each have quite different relations to the police, the law, and the ultimately powerful Russian Federal Security Bureau. All of these roles operate on trust, but trust resting on different premises and involving far greater vulnerability for some than for others. The livelihoods of thousands of people in Siberia and the Russian Far East depend not only on laws promulgated and constantly changed in Moscow, but also on how these regulations are enacted on the ground by the more powerful actors in these networks. A change that from a distance looks quite small - an alteration in the tariffs for import of cars, or a rise in the rent taken by licensing officials - can arouse such popular anger that public protests ensue, as described

14 The declared value of goods is used to calculate the sum customs officers transfer to state coffers, as well as the shares they take for themselves and their seniors.

15 The private brokers ('unofficial robbers') tend to diminish the internal coherence of the network, while the move of Chinese owners to establish their business on the Russian side, covert as it has to be, tends to strengthen it, though this very fact makes it more difficult for any outsider to enter the given market (Ryzhova 2013, 277). 
in Holzlehner's chapter. ${ }^{16}$ Yet even though relations between citizens and officials are constrained and unequal, crucial elements of their economic agreements rest on trust; as Humphrey argues in her chapter, the breach of trust is an emotional matter and it is this that gives rise to public fury.

\section{Concluding thoughts}

It should be noted that the vast majority of people in these borderlands who earn their living by trading do not think of themselves as traders. Mrs. Kim, for example, who appears in Chapter 10, used to be a civil servant and a member of the Chinese Communist Party: she began her trading almost by accident, and after the collapse of her Russian venture in her 6os, she returned to life as a housewife in Yanji, albeit always alert to ways of earning money on the side. ${ }^{17}$ On both sides of the border, many dealers and shop workers are well-educated people earning money for a particular purpose, paying off a debt, or filling in a gap between other jobs. Trading is thus often not an end in itself or explicitly rationalized into a set of named business practices, and it is more likely to be an episode in a life lived with other values in mind.

Just as many actors are reluctant to call themselves traders, they also usually leave unsaid the way in which their business depends on trust. One of the aims of this book has been to explore the different 'shapes' of trust among people of diverse cultures, and the chapters introduce ideas and vocabularies from Russian, Chinese, Mongolian, Korean, and Evenki actors. Our ethnography indicates that while people may operate through

16 Kyrgyz are unusual among traders in their willingness to take collective public action, such as their protest in 2003, signed by 33 people, against the raising of the daily bribe taken by a member of the sanitary police in Mezhdurechensk. http://www.centrasia.ru/newsA.php?st=1046773320. 17 When the borders opened and Chinese citizens were allowed to travel abroad, Mrs. Kim went with her husband, a rice farmer, to Kazakhstan just to look around. They took some Chinese-manufactured goods to sell and were so surprised at their popularity that Mr. Kim even sold his own clothes and shoes. The Soviet Koreans gave them 100 invitations to Russia, which they sold to their neighbours on their return to China. They made so much money on this first trip that they decided to take up trading full-time. They went to Omsk for a few years and then moved to Ussuriisk. Their business combined contacts in China supplying them with electrical kitchen appliances, along with contacts in Moscow with 'black people' (Central Asians, Caucasians) who supplied DIY goods for them to sell. On their return to China, Mr. Kim opened a factory to manufacture an energy-saving boiler he had invented and patented, and Mrs. Kim looks after her garden. The couple are devoted Christians (Hyun-Gwi Park, personal communication). 
relations of trust and mistrust, they rarely make use of the corresponding linguistic terms, especially in reference to themselves. Rather, actors mention familiar kinds of relationships that are tacitly understood to imply trust. Examples are anda ('blood-brother', 'buddy') among Mongolians, guanxi ('making useful contacts') among Chinese, hyŏngnim ('brother' among Chinese Koreans), and 'companionship' among Evenki. Each of these implies its own kind of moral economy that stands as an ethical counterweight to naked commercial individualism (see Osberg 2016, 51 for the case of guanxi). If a high-flown and morally loaded word for 'trust' is deployed in public it may immediately arouse distrust, as in the case of a Chinese construction firm trying to win clients in Russia described in the chapter by Humphrey. By contrast, the de facto building up of guanxi can happen across political and cultural boundaries, as Namsaraeva's chapter shows, even in the absence of much in the way of language. In fact, the ethnography suggests that trust often operates subconsciously, in the same way as liking a person one meets, or taking a dislike to someone else for no reason one can easily explain. Sign systems (after Luhmann) hung out specifically to demonstrate trustworthiness or reliability may simply not register, especially if they are the product of a different culture; and, on the other hand, they may be understood only too well - as tactics - and therefore fail in their aim. Yet, even if actual living trust works to a great extent intuitively, this does not mean that it can be left to the discipline of psychology. For 'intuitions' arise from the lessons, experiences, and discourses of long ago that subconsciously influence people, and these are the product of the history of their societies. This is why I am very glad as editor that several chapters in our book, especially those by Peshkov, Namsaraeva, Park, and Holzlehner, provide historical accounts that give depth to, and, in some ways explain, their descriptions of the present.

We should note, however, that the fact that people do not often talk about trust in their daily lives does not mean that the ways such a concept is rendered semantically are unimportant. On the contrary, as Martin's chapter shows in the case of Russian, different understandings of doverie ('trust') have profound import for motivating ethical attitudes. Also, if we look at Martin's analysis of doverie in comparison to the connotations of the English 'trust' this begins to suggest a divergence in what we might think of as the cosmological place of trust in different cultures. As Martin has commented to me, we could ask whether the English-language 'trust' is merely a secularized Protestant theological concept. Perhaps. But could one not argue conversely that its usage in early modern commercial society was always more economic than religious. It was used in quasi-religious ways (see 
'In God we trust' on the US dollar), but might these not be a re-transposition of the prevailing economic idiom of 18th century mercantilism back onto relations with God? In Russian, on the other hand, the religious root of trust - do-verie ('before faith') - is unmistakable, whereas the economiccommercial applications of the term seem opaque. Indeed, ethnography in Russia suggests that when taking practical decisions religion-infused doverie can often be an inappropriate word, and people will reach for a range of other ideas that suit the economic situation, such as nadezhnyi ('reliable', 'promising', 'hopeful') or even avos' ('taking a chance'), as discussed in the chapter by Humphrey. If doverie is indeed about transposing or extending the relations adopted towards God onto relations with people, then the lack of hand-wringing about its absence in the marketplace is more understandable - as is the need for a countervailing Russian video campaign to remind people that doverie exists in real life, despite the prevailing norm of cynicism and the popularity of the idea of post-truth. ${ }^{18}$

This question of the moral landscape in which trust is situated should be born in mind when reading the chapters that mention the analogous concepts in Chinese (Namsaraeva) and Korean (Park). These reveal a contrast between trust as something like a substance (the Chinese-originated Korean term is 신용/信用 sin-yong, 'credence, credit') and trust as an emotion, hope, or belief (the Korean indigenous term is written/Romanized as 믿음 mid-eum, also used as a verb, 믿다 midda for 'believing in' another person). ${ }^{19}$ Sin-yong is mainly used as a noun: something that one attributes to another person and can be 'lost' (diminished), whereas mid-eum can either exist or not exist. Bernard Williams was a philosopher unusually attuned to anthropology, and his comments on trust are pertinent here:

Those who treat it [trust] as having an intrinsic value must themselves be able to make sense of it as having an intrinsic value. This means that its value must make sense to them from the inside, so to speak: it must be possible for them to relate trustworthiness to other things that they value, and to their ethical emotions. [...] We have to see what these other values may be that surround trustworthiness, values that provide the structure in terms of which it can be reflectively understood. (Williams 2002, 91-2)

18 The series of films is aimed to remind people: you may not realize it, but you do trust people like air-traffic coordinators, grey-haired engineers, or invisible call-centre operatives. https:// snob.ru/selected/entry/121233.

19 In Mongolian, naidvartai, the expression most often translated as 'trustworthy', is based on the verb naida- ('to hope'), which implies that there may be idealism, but little certainty, attached to the act of trusting. 
The chapters in this volume indicate a range of 'other values' (profit, rationality, hope, security, kinship obligation, etc.) held in different cultures that surround and give sense to trust and mistrust. But importantly, all of the essays one way or another point to the centrality of personal fidelity when people attempt to create trust, or make it work for them, or bewail its loss. To my mind, this lends support to Williams' argument about the close connection of trust and truth, and specifically truth as a virtue that people uphold. 'Truthfulness is a form of trustworthiness' (Williams 2002, 94). When someone trusts another person, he or she takes on board an implicit promise from that person, 'I will do it', which could be expressed in any language, or indeed not through words but in an understanding conveyed in other ways (a glance, a nod). He or she must judge that promise to be sincere and accurate - or, more specifically, must understand the sincerity not as something guaranteed by obvious self-interest, for that might abruptly change direction, but as something proceeding from a disposition towards sincerity as a virtue (ibid: 95) that these actors hold in common. The ethnography presented here suggests that we should add that the sincerity guided by this disposition should be directed to me, the giver of trust.

An important conclusion that emerges from this book is that for a person to be able to be truthful in this way, they must have sufficient personal autonomy to make such a commitment and possess the ability to carry it out - and yet for a wide range of reasons most people of the borderlands do not believe that others have such individual autonomy and/or ability. These others may be conceptualized as a group whose internal bonds forbid true sincerity outside it (see the chapter by Peshkov and my earlier comments about attitudes toward Kyrgyz traders), or in the case of an individual business person, it may be obvious that their ability to be trustworthy and actually execute an agreement is compromised by external economic events, such as changing exchange rates, international sanctions, etc. (see the chapter by Humphrey). And, as shown in the devastating chapter by Safonova and Santha, ordinary actors' knowledge of the working of Russian power hierarchies has the effect of denuding actors of their capacity to be autonomous: any person is understood as subject to political pressure from those with greater clout, depriving all of these others of the ability to be sincere (to me), or to carry out whatever they had promised. There are perhaps cultural implications here too. For there are expectations about personhood and sociality built into the understanding of the way society works in general, as well as into specific ideas and practices (Russian doverie, Chinese guanxi, Korean dobe), that must inflect relations of trust/mistrust. 
These expectations structure the transactions, rather than being structured by them. ${ }^{20}$ With these considerations in mind the prevalence of mistrust becomes more understandable. It does not lie in comprehensive negativity and pessimism, nor in the 'refusal of all values and norms on which the earlier socialist system had been based' (Oleinik 2005 57), but rather, on the contrary, in having ideas of virtue, such as trust and truthfulness, but experiencing difficulty in finding someone to whom they apply.

\section{Acknowledgements}

I am very grateful to Partha Dasgupta, Liz Fox, Baasanjav Terbish, Loretta Kim, Sayana Namsaraeva, Hyun-Gwi Park, Madeleine Reeves, Natalia Ryzhova, Matt Candea, and especially Dominic Martin and Taras Fedirko for their valuable help in the writing of this introduction.

\section{References}

Allard, Olivier, 2012. Bureaucratic anxiety. HAU: Journal of Ethnographic Theory, 2(2), pp. 234-56.

Allard, Olivier, Carey Matthew and Renault Rachel, 2016. De l'art de se méfier. Tracés, 31, pp. 7-20.

Baier, Annette C., 2004. Demoralization, trust, and the virtues. In Cheshire Calhoun (ed.), Setting the Moral Compass: Essays by Women Philosophers. Oxford: Oxford University Press, pp. 176-9o.

Banfield, Edward C., 1958. The Moral Basis of a Backward Society. New York: Free Press.

Billé, Franck, Delaplace Gregory, and Humphrey Caroline (eds.), 2012. Frontier Encounters: Knowledge and Practice at the Russian, Chinese and Mongolian Border. Cambridge: Open Book Publisher.

Carey, Matthew, 2017. Mistrust: an Ethnographic Theory. Chicago: HAU books. Cook, Karen (ed.), 2001. Trust in Society. New York: Russell Sage Foundation. Cook, Karen, Russell Hardin, and Margaret Levi (eds.), 2005. Cooperation Without Trust. New York: Russell Sage Foundation.

Corsin Jimenez, Alberto, 2011. Trust in anthropology. Anthropological Theory, 11(2), pp. 177-196.

20 For a similar point made in the context of discussion of the moral economy of Chinese underground networks, see Osburg $(2016,56-7)$. 
Dasgupta, Partha, 1988. Trust as a commodity. In Diego Gambetta (ed.), Trust: Making and Breaking Cooperative Relations. London: Basil Blackwell, pp. 49-73.

Delhey, Jan and Kenneth Newton, 2003. Who trusts? The origins of social trust in seven societies. European Societies, 5(2), pp. 93-137.

Dietz, Graham, Nicole Gillespie, and Georgia T. Chao, 2010. Unravelling the complexities of trust and culture. In Organizational Trust: A Cultural Perspective. Cambridge: Cambridge University Press, pp. 3-41.

Fitzpatrick, Sheila, 2005. Tear Off the Masks! Identity and Imposture in Twentieth Century Russia. Princeton: Princeton University Press.

Fukuyama, Francis, 1995. Trust: the Social Virtues and the Creation of Prosperity. New York: Free Press.

Gade, Christian B.N., Rane Willerslev, and Lotte Meinert, 2015. 'Half-trust' and enmity in Ikland, Northern Uganda. Common Knowledge, 21(3), pp. 406-419.

Gambetta, Diego (ed.), 1988. Trust: Making and Breaking Cooperative Relations. London: Basil Blackwell.

Gellner, Ernest, 1988. Trust, cohesion and the social order. In Diego Gambetta (ed.), Trust: Making and Breaking Cooperative Relations. Oxford: Wiley-Blackwell, pp. 143-57.

Hardin, Russell, 2002. Trust and Trustworthiness. New York: Russell Sage.

Hardin, Russell (ed.), 2004. Distrust. New York: Russell Sage.

Hawley, Katherine, 2014. Trust, distrust and commitment. Noûs 48(1), pp. 1-20.

Horie, Norio and Konstantin Grigorichev, 2016. Evolyutsiya kitaiskikh rynkov v Sibirii: peresborka "kitaiskosti" i otkrytie "zakrytykh" lokal'nostei [Evolution of Chinese markets in Siberia: the re-assembly of "Chineseness" and the opening of "closed" localities]. https://www.researchgate.net/publication/294764401.

Hosking, Geoffrey, 2010. Trust:Money, Markets and Society. London, New York, and Calcutta: Seagull Books.

Latham, Kevin, 2016. Differentiating cynicisms: irony, cynicism and the new media in contemporary China. In Hans Steinmüller and Susanne Brandtstadter (eds.), Irony, Cynicism and the Chinese State. London: Routledge, pp. 155-173.

Luhmann, Niklas, 1979 [1968]. Trust and Power. Chichester: Wiley.

Marsden, Magnus, 2016. Trading Worlds: Afghan Merchants Across Modern Frontiers. London: Hurst and Company.

Mishler, William and Richard Rose, 2001. What are the origins of political trust? Testing institutional and cultural theories in post-communist societies. Comparative Political Studies, 34(1), pp. 30-62.

Mishler, William and Richard Rose, 2005. What are the political consequences of trust? A test of cultural and institutional theories in Russia. Comparative Political Studies, 38(9), pp. 1050-1078.

Mühlfried, Florian, 2014. A taste of mistrust. Ab Imperio, 4(2014): 63-68. 
Namsaraeva, Sayana, 2014. Zabaikal'sk I Kyakhta: istoricheskie I sovremenniye paralley v prigranichnykh torgovykh anklavakh v transportnykh koridorakh mezhdu Rossiei I Kitaem [Zabaikal'sk and Kyakhta: historical and presentday parallels in trade enclaves in the transport corridors between Russia and China]. In L.V. Kuras (ed.), Prigranichnyi urbanizm: imperskaya I postimperskaya praktika. Ulan-Ude: IMBT, pp. 110-125.

Oleinik, Anton, 2005. A distrustful economy: an inquiry in foundations of the Russian market. Journal of Economic Issues, 39(1), pp. 53-74.

O'Neill, Onora, 2002. A Question of Trust. Cambridge: Cambridge University Press.

Osburg, John, 2016. Morality and cynicism in the 'grey' world. In Hans Steinmüller and Susanne Brandtstadter (eds.), Irony, Cynicism and the Chinese State. London: Routledge, pp. 47-62.

Park, Hyun-Gwi, 2016. One River and Three States: The Tumen River Triangle and the Legacy of the Postsocialist Transition. Asian Perspective. July-September 2016, Vol. 40, No. 3, pp. 369-392.

Putnam, Robert, 1993. Making Democracy Work. Princeton, N.J.: Princeton University Press.

Putnam, Robert, 2000. Bowling Alone: the Collapse and Revival of American Community. New York: Simon and Schuster.

Reeves, Madeleine (ed.), 2012. Movement, Power and Place in Central Asia and Beyond. London and New York: Routledge.

Reeves, Madeleine, 2014. Border Work: Spatial Lives of the State in Rural Central Asia. Ithaca and London: Cornell University Press.

Robbins, Joel, 2008. On not knowing other minds: confession, intention and linguistic exchange in a Papua New Guinea community. Anthropological Quarterly. 81(2), pp. 421-9.

Rosanvallon, Pierre, 2008. Counter-Democracy: Politics in an Age of Distrust. Translated by Arthur Goldhammer. Cambridge: Cambridge University Press.

Ryzhova, Natalia, 2013. Ekonomicheskaya integratsiya prigranichnykh regionov [Economic integration of border regions]. Khabarovsk: IEI DVO RAN.

Sakwa, Richard, 2011. Russia's identity: between the 'domestic' and the 'international'. Europe-Asia Studies, 63(6), pp. 36-48.

Shlapentokh, Vladimir, 2006. Trust in public institutions in Russia: the lowest in the world. Communist and Post-Communist Studies, 39(2), pp. 153-74.

Shlapentokh, Vladimir, 2007. China in the Russian mind today: ambivalence and defeatism. Europe-Asia Studies, 59(1), pp. 1-21.

Simmel, Georg, 1950. The Sociology of Georg Simmel. Translated and edited by Kurt H. Wolff. Glencoe, Illinois. Free Press.

Sodnompilova, Marina M., 2010. Migratsionnye protsessy v Baikal'skom regione: dominiruyushchie formy trudovoi deyatel'nosti mongol'skikh grazhdan v 
Buryatii [Migration processes in the Baikal region: the dominant forms of labour activity of Mongolian citizens in Buryatia]. In B.Z. Nanzatov (ed.), Transgranichnye migratsiiv prostranstve mongol'skogo mira: istoriya I sovremennost' [Transborder migration in the Mongolian world: history and the present-day]. Ulan-Ude: BNTs SO RAN, pp. 8-29.

Steinmüller, Hans, 2016. Introduction to Hans Steinmüller and Susanne Brandtstadter (eds.), Irony, Cynicism and the Chinese State. London: Routledge, 3-13.

Tagliacozzo, Eric, 2005. Secret Trades, Porous Borders: Smuggling and States Along a Southeast Asian Frontier, 1865-1915. New Haven/London: Yale University Press.

Turnbull, Colin, 1972. The Mountain People. New York: Simon and Schuster.

Urinboyev, Rustamjon and Abel Polese, 2016. Informal currencies: a tale of Misha, and informal practices among Uzbek labour migrants in Russia. Journal of Contemporary Central and Eastern Europe, 24(3), pp. 191-206.

Van Schendel, Willem and Abraham Itty (eds.), 2005. Illicit Flows and Criminal Things: States, Borders, and the Other Side of Globalization. Bloomington and Indianapolis: Indiana University Press.

Varnavskii, P.K., 2010. 'Nikakikh problem net, yazyk znayu plokho, s dokumentami vse v poryadke': strategii adaptatsii migrantov iz Tsentral'noi Azii v Zabaikal'e (na primere goroda Krasnokamenska) ['There are no problems at all, I know the language badly, the documents are all in order': adaptation strategies of Central Asian migrants in Zabaikalia, the example of Krasnokamensk]. In B.Z. Nanzatov (ed.), Transgranichnye migratsii $v$ prostranstve mongol'skogo mira: istoriya I sovremennost' [Transborder migration in the Mongolian world: history and the present-day]. Ulan-Ude: BNTs SO RAN, pp. 30-58.

Wang, Shaoguang and Xin Liu, 2002. The base of trust: a rationalist interpretation. Sociological Research. http://en.cnki.com.cn/Article_en/CJFDTOTALSHXJ200203002.htm.

Weiying, Zhang and Ke Rongzhu, 2002. Trust in China: a cross-regional analysis. Economic Research Journal. http://en.cnki.com.cn/Article_en/CJFDTOTALJJYJ200210007.htm.

Williams, Bernard, 2002. Truth and Truthfulness: An Essay In Genealogy. Princeton: Princeton University Press.

Zelizer, V., 2005. The Purchase of Intimacy. Princeton/Oxford: Princeton University Press. 



\title{
Déjà vu of Distrust in the Sino-Russian Borderlands
}

\author{
Sayana Namsaraeva
}

Humphrey, Caroline (ed.), Trust and Mistrust in the Economies of the China-Russia Borderlands. Amsterdam: Amsterdam University Press, 2018

DOI: $10.5117 / 9789089649829 /$ NAMS

\begin{abstract}
This chapter presents a long historical view of the Sino-Russian distrust landscape. It presents situations of déjà vu through comparisons between present day and longue durée perspectives on cross-border interactions. Even aside from such historical and contemporary encounters of mutual distrust, Russia and China themselves are both societies with low levels of public trust. The cases of misuse of Chinese labour in Russia presented here clearly demonstrate that deficiencies of legislation and institutional weaknesses in both countries facilitate the criminalization of the transactions involved (e.g., human trafficking, illegal migration) and create conditions for co-ethnic abuse in the low trust environment of the Sino-Russian borderlands. Analyzing this situation, the chapter explores non-Western understandings and vocabularies of trust, such as Russian doverie and blat and Chinese guanxi, kekeo, and xinyoung, and indicates how these are used in economic encounters.
\end{abstract}

Keywords: Sino-Russian borderlands, Kyakhta Treaty, Eastern Siberia, Chinese labour migrants in Russia, co-ethnic abuse, human trafficking

\section{Introduction}

The notion of trust has been the focus of intense research in the social sciences in recent decades (Hardin 2003; Gambetta 1988; Levi and Stoker 2000; Hosking 2010; Dasgupta 1988), including in social anthropology (Corsin Jimenez 2011; Haas 2012). This scholarship examines not only the semantics of the notion in different disciplines and cultures, but also a range of other relevant concepts such as trustworthiness, distrust (mistrust), reliance, 
loyalty, and reputation. From this literature, it emerges that trust and distrust as paired notions - antagonistic and mutually negating - exist in a dynamic interim zone between the ideal clear cases of trust and ideal clear cases of distrust. Trust and distrust, while mutually exclusive, as Edna Ulmann-Margalit remarks, are not mutually exhaustive: there is a wide spectrum of cases characterized by 'neither trust nor distrust', which she calls 'trust agnosticism' (Ulmann-Margalit 2004, 6o-61).

However, agnosticism about trust (in the sense of holding the view that trust is unknowable) is difficult to find and document in real life, and it seems that another approach - talking about trust through the concept of distrust - would be more productive, since it allows the illustration of social relations between groups and individuals in a more nuanced way. This is well demonstrated by researchers who have attempted to theorize distrust using different scales and grades. They propose the now commonly accepted view that distrust can create the conditions necessary for qualified trusting, i.e. moving from the extreme of 'bad' paranoid distrust (or 'hard' distrust) to 'good' and 'prudent' (or 'healthy') distrust, which allows actors to build some degree of cooperation and familiarity (Larson 2004; Harding 2003). Distrust varies by issue and time period, but in cross-border situations the trust/distrust landscape is exceptionally complex, because the relations between groups and individuals of different nationalities are dependent on other relations at a 'higher' level, i.e. between states: they respond to the level of trust and distrust between the neighbouring countries. This paper attempts to sketch a range of situations of distrust to show both the transformation of distrust into qualified trust between individuals, and how these relationships are affected by inter-state attitudes and policies.

\section{The language of trust}

First, I must add a word about the words for 'trust' used in Sino-Russian cross-border interactions, since these affect practices. Social anthropologists are interested in non-Western understandings of trust and distrust in various ethnographic contexts, probing the problem of the inadequate linguistic translation of the trust category, which evidently has a range of meanings in different languages and cultural settings (Markova \& Gilespie 2008). ${ }^{1}$ The Russian notion of doverie/nedoverie ('trust'/'mistrust'), which

1 For example, Japanese shinrai (信 赖), usually translated as 'trust', has a connotation of spiritual and moral obligation, and some Japanese authors suggest that it would be better 
shares a root with vera ('belief and faith') (see Martin, this volume), encounters a rich variety of trust-related conceptions in China. The Chinese writing system has several characters for trust. The monosyllabic xin (信) is the most frequently used and also refers to 'belief and faith', although it has other meanings, such as 'letter' and 'to write a letter'. This character is also used as a morpheme in two-character words such as xiangxin ( 相信), xinyong (信用), and kexin (可信), to express a wide spectrum of trust-related notions: xiangxin is used to talk about belief and faith, while xinyong refers to the usefulness of trust, credibility, and creditworthiness mostly in economic relations. ${ }^{2}$ Kexin (the short form of 可以相信) stands for possible reliability and convincingness. However, in a Chinese context other characters also can express the concept of trust, such as guanxi (关 系), which can be translated as 'personalized trusted relationships', and kekao (可靠), which means 'reliable', 'trustworthy', or - more precisely - the possibility of trusting in a person's capacities.

During my fieldwork, when Chinese businessmen were talking about their affairs in Russia they most often used guanxi and kekao as working terms, leaving xiangxin, xinyong, and kexin for the domain of ideal honesty and moral obligations. They also used derivatives of guanxi and kekao to talk about distrust (as the absence of trust), when trust has not been established yet, or about bad relations that potentially could be improved. For example, bu kekao can mean the absence of reliance and even the end of trustful relations with no hope of improvement, while guanxi bu hao ('bad relations') can still improve to you guanxi ('having relations'), which does not specify whether they are good or bad, or even to guanxi manman hao le ('slowly improving relations'). The economic-anthropological literature on Chinese society (Kipnis 1997; Tong and Young 2016) suggests that guanxi is a process, over and above kinship, of establishing and developing useful personal contacts through continual social interaction. For Chinese businessmen in a trans-border context, working in a hostile foreign environment and undergoing the uncertainties of the Russian economy and legislation - where the implementation of law can be subject to the personal interpretation of

conceptualized as the assurance of mutual cooperation in committed relations (Yamagishi 2003). Other languages such as Hebrew demonstrate deep-level connections between the ideas of 'trust', 'belief', and 'faith' by sharing the same root word (Ulmann-Margalit 2004, 62). While German does not distinguish between belief and faith, it has two different words for trust, i.e., trauen, which indicates trust in someone's honesty, and vertrauen, which can also mean trust in a person's abilities (Haas 2012, 156).

2 For example, 'credit card' (xinyongka, 信用卡) is translated into Chinese using these characters. 
local officials -, building guanxi with local officials and business partners makes real security and economic sense.

In my conversations with Chinese businessmen who had lived and worked in Eastern Siberia for many years, they preferred to use the Russian word blat ('making use of relationships') rather than doverie ('trust') when talking about the importance of having good guanxi with Russian officials to get their patronage and protection. In fact, any chance of an introduction to local officials was perceived by Chinese businessmen as an invitation to make an informal agreement for their protection in the given locale. Interestingly enough, Chinese businessmen very often used the word dluga (deformed from Russian drug, 'friend') to talk about their Russian business partners, thus stressing the necessity of having personal relationships zuo shengyi ('to do business') in Russia. Maybe this was also a way of indicating that their Russian colleagues were equally vulnerable to exploitation by institutions involving Russian officials.

We can conclude from this brief survey that the nuances of 'trust' for Russians and Chinese are different. Although blat in all its meanings seems to be a concept similar to guanxi, and both play a crucial part of life in China and Russia (Kononenko and Moshes 2011), in Russian social networking blat is more about harvesting the results of pre-established personal contacts than establishing new ones. Moreover, guanxi is a 'neutral' word in Chinese society, whereas in Russia blat definitely has a negative connotation, and is often linked to corruption.

\section{Cross-border distrust in the longue durée}

The Sino-Russian border is an example of an international border that has been under recurrent and intense stress since its establishment at the end of the 17th century. During this long period, power misbalances and political mistrust between the two states pervaded territorial disputes, ${ }^{3}$ ethnic conflicts, ${ }^{4}$ the border clashes of the $1960 s,{ }^{5}$ the arms race of the late Soviet period, and the militarization of not only frontier spaces but also of peoples' mindsets, which were poisoned by the suspicion that spies were

3 Long-lasting Russia-China border disputes were officially settled in 2005 .

4 For Russian versions of sinophobia and historical cases of abusing Chinese in late imperial Russia and at time of the Stalinist purges, see Victor Dyatlov (2011) and Vladimir Datsyshen (2008).

5 For example, military conflict between the Soviet Union and China at the height of the China-Russia political split in 1969 at Damansky Island on the border. 
everywhere at home. This situation of living in close proximity to a potential enemy was the foundation for the emergence of paranoia as a form of a 'hard' distrust - a generalized predisposition to distrust everyone coming from the other side of the border (see Peshkov, this volume). This characterized both the domestic situation and the international relations of the Soviet Union during the Iron Curtain period, not only with the capitalist West but also with communist China.

With this legacy of political distrust over several centuries, the political relations between Russia and China have been 'reset' only recently. The foundation of communist statehood in China in 1949 'softened' distrust for a time in the so-called 'honeymoon period of the 1950s, but it 'hardened' again with Mao-Khrushchev's ideological disagreements and power competition. Only in the last few years has a certain degree of inter-state trust been rebuilt for economic and strategic reasons.

But the question still remains: how long will it take to overcome the historical psychological state of distrust between the two countries and make people reconsider their default assumption of distrust - a question especially relevant at present when in official Russian rhetoric China is viewed no longer as a 'potential danger' but as a 'strategic partner'. ${ }^{6} \mathrm{Did}$ the latest political 'reset' of Sino-Russian relations in the 2000 s bring a 'reset' to people's minds, and more confidence and reliability in the human relations between Chinese and Russians? To answer these questions and to see how people respond to the changing political climate and new economic opportunities at the border, I will examine some examples of how both Russians and Chinese ${ }^{7}$ tried to shift from the paranoid extreme of distrust toward more reliance on each other - which, however, can reverse if this growing trust is betrayed and then, possibly, switch again later. In other words, this is a study of a zone of equivocal and shifting relations typical of borderlands, which are inherently highly dynamic spaces, as Donnan suggested. ${ }^{8}$

6 An official treaty signed in 2001 proclaimed 'Friendship and Cooperation' between China and Russia. For a detailed analysis of how Sino-Russian relations shifted from the 'hard' distrust of the 1960s toward the 'soft distrust' of the 200os, see Nye (2015); Quested (2014).

7 Here I use 'Chinese' and 'Russians' as citizenship affiliations with multi-ethnic compositions. Co-ethnics divided by the border with different citizenships, such as Koreans, Evenki, Buryats and Russians, constitute the main trans-border groups. They were the first to foster more trusting cross-border relations, due to close kinship ties and the fact that they managed to maintain links despite the periods of official distrust between China and Russia. See Namsaraeva (2012).

8 Border zones are 'areas of dynamic human relations that never stop at borderlines' (Donnan $2010,7)$. 
It is clear that the Sino-Russia borderlands have experienced different scales and grades of distrust (rather than trust) over time. More broadly, we can say that a certain distrust pervaded all aspects of social, political, and economic interactions, since a closely patrolled border is in itself is a manifestation of distrust: an institutionalized device to manifest the perceived lack of trustworthiness of foreign subjects and the suspicion of outsiders. Given this history, it will be argued that distrust is still the baseline of human interactions in the Sino-Russian borderland, coloured by alternating periods of 'cooling' and 'thawing' in political relations. The question is, how do people negotiate this distrust and make it workable what kind of appropriate caution do they exercise while moving from 'bad' distrust to 'good' distrust?

\section{Beheaded Dragon and Poisoned River}

A brief account of the history of interaction between the Russian and Chinese empires in the mid-18th century will be helpful for understanding the suspicion at the foundation of their initial relations. The bilateral Nerchinsk Treaty at the end of the 17 th century, an instrument to reduce costly open conflicts at the margins of these empires, allowed both sides to limit their aggression and agree to start territorial and border delimitation. As international policy specialists have remarked, 'the greater the distrust, the more detailed negotiators will insist that a treaty must be in order to cover all potential loopholes' (Jervis 1976, 45, quoted in Larson 2004, 34). Mutual distrust motivated diplomats to craft additional agreements and numerous amendments, and to initiate new treaties with more detailed addenda and conventions. There were around a dozen further treaties, protocols, and conventions between Russia and China during the 18 th and 19th centuries, in addition to numerous busy diplomatic missions whose task was to sense potential dangers and acquire information about the other country.

Perhaps the most vivid evidence of the Russians' archaic distrust of the Chinese is the official coat of arms of the border town Kyakhta, which was established as the only point for direct trade between Russia and China after the Kyakhta Treaty of 1727 (Figure 1). The coat of arms shows a shield under the Russian imperial crown. The shield is divided into four equal parts, of which two depict Russian and Buryat border guards with a horn of abundance, symbolizing the two important aspects of the border (security and trade). The other two sections contain the head of a golden dragon. But 
Figure 2 The Coat of Arms and official flag of Kyakhta, Russia

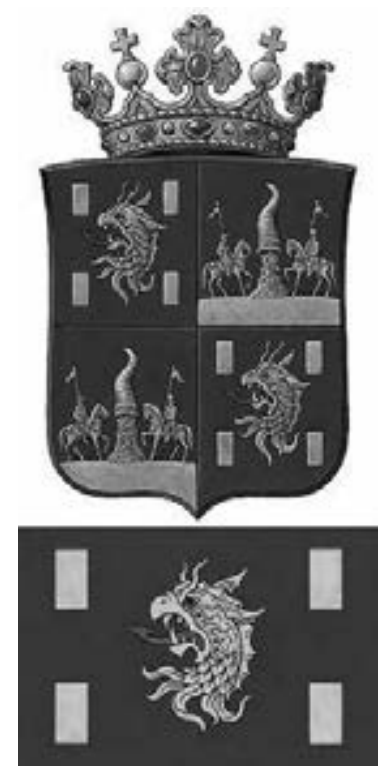

this is not just a head of a dragon: as an 1861 document states, it was meant to depict 'a severed head (otorvannaya golova) with red eyes and red tongue'; 9 when the dragon as a whole signified China itself. The same symbol of the guillotined dragon became the official flag of Kyakhta town, which is still in use. ${ }^{10}$ It should be noted that a beheaded and vanquished dragon is one of the most popular motifs of Russian orthodox iconography, depicting Saint George's victory over pagans. Indeed, the newly established border was perceived by Russians as the front line of the confrontation between European Christianity and Asian pagans. Perhaps this is one reason why Kyakhta was so rich in large Orthodox churches; it has the most outstanding and impressive ecclesiastical architecture in all of Asiatic Russia east of the Urals. The largest and most monumental, the Church of the Resurrection (Voskreseniya), ${ }^{11}$ was built just a few meters from the border next to the

9 Doc. 28:22 in Folder 92, 'Pre-Revolutionary documents dated between 1851-1862', Buryat Republic National State Archive, Russia.

10 Interestingly, the coat of arms of Kyakhta has not been modified since then, and in 2008 it was again authorized by the Heraldic Council of the Russian Federation as the official symbol of Kyakhta. Accessed from the official site of Kyakhta municipal administration http://admkht.ru/ 11 However, notwithstanding the official policy of distrust (periodic blockades, armed guards, inspections, customs tariffs, etc.) at this border crossing point, local rumour held that there 
Custom Clearance pavilions, even though the town centre and its Christian population was located a few miles away.

It was suspicion and distrust that drove Count Raguzinsky, the Tsarist envoy who signed the Kyakhta treaty, to establish this trading place at such a remote, desolate site, away from existing trade routes and the large navigable Selenga and Chikoi Rivers. He chose it because the Kyakhta stream was the only river to flow from the Russian side into China, meaning that it could not be poisoned by the Chinese. As a local border officer wrote, trying to justify Raguzinsky's choice and the priority he gave to security over trade interests and convenience:

There were plenty of good places to establish a trade point, but there was a problem: all the rivers run from China to Russia. And what if a bad time comes, with mutual enmity, surely the Chinese will poison the water and Russians will die! What's to be done? At whatever cost it was necessary to find a river that would flow to China. And he found the Kyakhta stream ${ }^{12}$. (Cherepanov 1867, 47)

But in reality it was the Russians who 'poisoned' the water and polluted the small rivulet by building several factories on its banks, washing their clothes in it, and watering cattle - to the extent that was soon nicknamed Gryaznukha ('the dirty one'). There were even public complaints published in a local newspaper 'Baikal' toward the end of the 19th century (Bagashev 1898).

Despite Kyakhta's flourishing trade of tea and fur, increasing turnover, and public rituals of friendship, such as joint celebrations of Chinese New Year and shared official banquets for Chinese and Russian border officials, and despite the establishment of personal trust with specific Chinese trade partners residing just on the other side of the border in Maimaicheng, Russians in Kyakhta still had mixed feelings about their Chinese neighbours. They constantly suspected them of cheating, giving underweight by using wrong-weighted scales, selling bad goods for high prices, making pricefixing arrangements for tea, etc. In mirrored fashion, Chinese merchants likewise blamed Russian merchants for cheating: Siberian furs sold by weight had metal bullets sewn into their paws; silver-plated base metal

was a smuggling underpass beneath the church, which allowed them to smuggle goods from the Chinese side during periods when official trade was closed. This demonstrates that locals didn't trust their governments' decisions when they contradicted their economic interests. Locals from both sides of the border continued to trade, but illegally.

12 All translations of quotations from Russian and Chinese languages are mine unless other names are indicated. 
was sold as pure silver (Trusevich1882 in Filippova 2005, 42); tea to resell to Europe ${ }^{13}$ was admixed with other leaves; and they even (rightly) accused the Russians of recycling and dying previously brewed tea (Russian ispitoi chai) to look like fresh tea ${ }^{14}$ (Subbotin 1892), thus damaging the reputation of Chinese tea in the European market. All of these trade practices, with many precautions taken to reveal their partners' bluff and disguise their own tricks, made distrust workable as a way to continue trade relations notwithstanding the often justified mutual suspicions.

Meanwhile, physical, cultural, and linguistic separation created a fertile ground for other mythical suspicions among the Russians, such as accusing the Chinese of using black magic to grow the vegetables that they sold in the Kyakhta market during winter and early spring (Cherepanov 1867). The Kyakhta citizens were simply not aware that the Chinese grew their vegetables in greenhouses just across the border behind the walls of Maimaicheng. Although the trade relations between merchants fluctuated around 'soft' distrust, which still allowed cooperation and exchange between the two sides, security dilemmas in international relations kept Chinese and Russian border officials in a condition of deep distrust: both sides built up military stations along the border. The Chinese side imposed trade blockades against Russia more than a dozen times during the 18th century as means of exerting political pressure; and both sides actively used intelligence and disinformation to protect their commercial and political interests. For example, Qing border officials issued a number of secret instructions for Chinese traders on how to spy on the Russian state and collect intelligence in Kyakhta. One such order from the end of the 19th century suggested that they should 'behave politely with Russians [in order to build trustful relations] as if they were good friends,' and also called on them 'to exploit the friendly attitude [of the Russians] and misinform them in an intimate and sincere manner about the bad harvest of silk this year [to keep the price of silk high]. ${ }^{15}$

13 European importers of tea (mostly English and Dutch) brough their tea from China by land across Russia and Russian Siberia. After the Opium Wars in the mid-19 ${ }^{\text {th }}$ century this transcontinental caravan trade was slowly replaced by sea trade (Toussaint-Samat 1992).

14 This cheap recycled tea was called chai dlya ubludkov ('tea for fools') in Russian merchant jargon and was further admixed with other substances, such as a local herb nicknamed Ivan chai ('tea for Ivan'), because its leaves look similar to tea leaves (Subbotin 1892).

15 'Daby vzaimno pol'zovat'sya ot nikh istinnoyu, budto po druzhbe predosteregat' ikh pro neurozhai shelku' (Secretnaya Instruktsiya, Doc 58 (BIII). Folder 1 Transbaikal region, Documents dated starting from 1894, Archive of the Russian Imperial Geographic Society in St. Petersburg). Only the Russian translation of the Chinese Secret Instruction was available for my research; the original text in Chinese was missing. 
These historical cases of distrust and suspicion are still recalled in popular memory when present day Russian and Chinese trade partners face difficulties and misunderstandings in making deals. This gives rise to perceptions of déjà $v u$ - the feeling of having 'already seen and lived through' such a situation - even if the historical recollections are sometimes erroneous.

\section{Déjà vu of Poisoning and Polluting}

In 2012, Russian regional news reported violent ethnic clashes between Russian villagers and Chinese labour migrants in Bil'chir village in Irkutsk region. The locals accused the Chinese workers employed at a local sawmill of polluting water in the Bratsk freshwater reservoir by washing their clothes in it. As a newspaper reported,

The Chinese ignored the requests of locals and responded in a very rude way. They even called for Chinese 'reinforcements' and a lorry full of other Chinese arrived from a neighbouring village to resist the locals. The locals had to retreat, but later they changed their mind and decided to visit the Chinese sawmill to try to sort out things peacefully. But the Chinese workers were very aggressive and attacked the 'peace delegates' using their sharpened tools. The delegates called their fellows, and according to the police report over seventy people were involved in an open fight from each side. The Chinese used heavy machinery to defend themselves and they crashed two cars that belonged to locals. Armed with sticks they also smashed the windows of other cars, threw stones and broken glass bottles. The locals surrounded the Chinese sawmill and set the wooden fence around it on fire. Only the intervention of the local police stopped the fight, but the conflict was not over. The locals demanded for the Chinese to be sent away from their village claiming that 'they behave like occupants; they devastate our land, destroy our infrastructure, poison the air and pollute water sources.' Locals called a community meeting to sign a petition to ban the Chinese timber business in their district and expel the Chinese from their village. ${ }^{16}$

16 Accessed from business and stock market news agency Profi-Forex: http://www.profi-forex. org/novosti-rossii/entry1008267942.html. More details about the incident are here: Woodworking industry news website http:/www.derevo.info/ru/news/detail/6661 and Irkuts regional news agency website http://baikal-info.ru/sm/2012/28/007001.html 
Regional TV reports emotionally depicted black smoke rising over the ruins of the sawmill and crashed cars. Journalists took interviews with several locals wounded in the fight from their hospital beds, showing their broken arms and legs in plaster. Local women complained about the misbehaviour of Chinese workers who attempted to abuse local girls, about the unbearable 24-hour noise of their power-saws that polluted the air, about how the heavy vehicles delivering timber were destroying the local roads, etc. The most convincing episode showed young children crying because their sleep was disturbed by the noise from the Chinese sawmill and affecting claims from their parents that noise and pollution from the mill was affecting their children's health. Obviously, the coverage of the Irkutsk media was more sympathetic to the villagers than to the Chinese and did not provide the latter's version of the story. The Chinese at the mill ignored all of the journalists' attempts to take interviews, repeating many times in broken Russian that they didn't speak Russian and that their boss had forbidden them from having any contact with the local people.

This case heated people's imaginations and was one of the most discussed topics in the whole of Eastern Siberia, including in neighbouring Buryatia, when I was doing fieldwork that summer. Because this was the first open ethnic conflict between Russians and Chinese in post-Soviet Russia and involved over a hundred people in an open fight, a special envoy from the Chinese Embassy in Moscow and a representative of the Chinese consulate in Irkutsk arrived together to mediate the conflict and protect the interests of the Chinese citizens, ${ }^{17}$ several of whom were under detention in the local police station after the fight.

The investigation revealed that there were economic reasons behind the conflict. Siberian timber had recently fallen dramatically in price in China, because that summer too many sawmills had joined the region's profitable timber market ${ }^{18}$ and the market was oversupplied. Since it was the locals, not the Chinese, who cut trees to sell to 'Chinese' sawmills, they lost

17 Chinese overseas embassies have a special envoy to protect the life, security, and business interests of their citizens abroad. Mr. Huang (names of informants are pseudonyms), who in 2012 was acting as a such (and whom I interviewed in Moscow few months after the incident), showed me two mobile telephones - 'hotlines' for emergency calls from Chinese citizens in trouble in Russia. His duty was to ensure the hotline was accessible at all times, and his busy travels all over Russia to rescue his compatriots demonstrated that Chinese business in Russia was getting more complicated and geographically diverse.

18 There were 15 sawmills operating in the Osinsky district according to journalists' investigations published by an on-line newspaper http://www.irk.kp.ru/daily/25907/2863688/. 
income because of this market fluctuation. But something non-economic, a tangle of disinformation and deception, was also an integral part of this situation. The complaints that the Chinese were guilty of ruining roads and infrastructure were groundless, since it was overloaded delivery lorries hired by local Russians that caused the problems. Furthermore, the real owner of the so-called kitaiskaya lesopilka ('Chinese sawmill') in Bil'chir was a Russian citizen from Irkutsk, and it was he, and not the Chinese workers, who was to blame for lowering the purchase price of timber in the village. It was the local administration of Bil'chir that, despite industrial regulations, allowed a sawmill to be placed just near the village in an empty dairy farm abandoned after the Soviet kolkhoz collapse. And locals also contributed equally to the pollution of the Bratsk reservoir by washing their cars on the shore and watering their cattle there.

Finally, there are state policy-level reasons for the antagonistic relations between the communities. The complicated and excessive Russian labour regulations virtually forced the sawmill owner to hire Chinese workers, because hiring locals would require additional payments for retirement schemes, holiday breaks, and sick leave, double payment for working overtime, and so on - extra costs that would destroy the whole business. Chinese labourers were much cheaper and could work three shifts per day, including nights, without weekends and holidays, and without the unexpected prolonged leaves caused by hangovers and spontaneous summer breaks to cut hay, collect berries, etc., that were habitual for locals. From the bureaucratic point of view, the only wrongdoing of the Chinese was that their trudovaya litsenziya ('labour license') issued by the Russian Federal Immigration Service (FMS) was registered not for the Irkutsk region where they were employed but for the neighbouring Zabaikal'sk region. This license allowed them to be employed only in agriculture - not in industrial enterprises - and not in other regions, since that would involve different taxation schemes and different regional quotas for employing foreign labour. ${ }^{19}$ But still, it was not the workers' fault that the Chinese employment agency that contracted them had illicitly traded them to another Russian region to do a different job. All of this meant that officially Chinese labour was not employed at that sawmill in Bil'chir - so there was no need to trust

19 For Russian legislation on foreign labour and the quota distribution between regions, see information posted on the official website of the Russian Ministry of Labour and Social Security: http://www.migrakvota.gov.ru/. For the approved quota for foreign labour for 2017 in Russia see here http://kommersant.ru/doc/3168874?utm_source=kommersant\&utm_medium=all \&utm_campaign=hotnews 
your eyes or the complaints of the locals about the Chinese 'polluting their nature and water'. On paper, this sawmill had official work contracts only with Russians (who actually had never been at the sawmill). So it was no problem for the Chinese workers to disappear like ghosts from Bil'chir the very day after the conflict. Local rumours stated that they been relocated to another sawmill in the same district.

But was this situation not strangely familiar? I asked my acquaintance Lena, who worked as a lawyer for a construction company in Ulan-Ude, how widespread this practice of trading Chinese workers is. Her firm had construction projects all over the region and widely hired Chinese labour. According to Lena, Zabaikal'sk, as a region directly bordering China, enjoyed a larger state quota for employing foreigners; ${ }^{20}$ businesses registered in Zabaikal'skii Krai took advantage of this privilege to trade excessive Chinese labour to other regions through middleman companies. One of Lena's duties was to arrange deals between the mediator firms in Zabaikal'skii Krai and Manzhouli, the border city that channelled Chinese labour to Russia, to find workers when her company needed more hands or when the permits of their Chinese workers were soon to expire. Lena explained to me that, thanks to Russian federal programs to subsidize domestic agricultural producers, extra privileges were given to such enterprises to bring in Chinese labour for vegetable growing. These agricultural firms also enjoyed lower tax rates than industrial enterprises for contracting foreign labour - thus making them very attractive for the various corruption schemes for the smuggling and misuse of Chinese labour. For this reason many businesses in this border region register themselves as 'agricultural farms' on paper to get access to cheap foreign labour quotas and to be able to 'trade' Chinese workers to other regions to do different jobs: construction, sawmills, building roads, mining, and anything that requires cheap, pliable labor ready to work in hard conditions on minimal wages.

This situation is also a déjà vu for Russia. Recall Nikolai Gogol's novel Dead Souls, which describes a venal 19th century society in which landowners

20 In 2015, a quota of around 80,00o people for access to the Russian domestic labour market was introduced for migrant workers from China. This is a large quota compared to those permitting entry to other foreign citizens (e.g. Turks or North Koreans) under the visa procedure. But these figures pale in comparison to the million-plus migrant workers from the countries of Central Asia who enter Russia under a visa-free regime (Gulina 2015). Interestingly, the labour quota for 2017 allows enterprises to have up to 50 percent foreign labour in agriculture, and even more in designated 'agricultural regions' (e.g. the Khabarovsk, Krasnodar, and Moscow regions) during the harvest season. This means that foreign labour will soon be traded through new channels and different regions. 
trade lists of the names of their deceased serfs, which are dushi ('souls') still accounted for in property registers. The owners of the serfs sell 'dead souls' covertly in order to pay less tax on their payroll of serfs, which includes those who die between tax assessments, while the buyer - the 'hero' of the novel - counts on being able to raise a large loan on the newly acquired paper serfs and pocket the money. Something like Gogol's hallucinatory phantasmagoria of 19th century Russia has reappeared in the 21st century, when fictive Chinese agricultural workers become souls that build roads and erect houses.

\section{'Trust... but check up!'}

This misuse of Chinese labour by trading 'Chinese souls' between regions and enterprises recalls my own personal experience from the mid-199os, when one summer I was hired by a local administration during my university holidays to translate their meetings with a Chinese construction team contracted to build a myasokombinat ('meat processing plant') in their district centre in Zabaikal'sk region. How surprised the administration was to realize that instead of a professional team of qualified engineers and builders they had received a group of peasants, all from one village somewhere in Zhejiang province in Southern China! I could communicate only with their team leader, Mr Liu, who indeed was an engineer accompanied by several professional construction workers, who could speak some standard Chinese putonghua. Engineer Liu explained that employment agencies in Manzhouli, quickly responding to the growing Russian demand for Chinese labour, recruited anyone who was interested in a seasonal job - mostly laobaixing ('unskilled commoners') from the countryside. So he and his small team of professionals were mixed with a larger group of untrained peasants and sent to Russia under the wrapping of a jianshe tuan ('construction team') to carry out the meat processing plant contract. Does this not remind one of the old Kyakhta trick of tea adulterated with other leaves wrapped as a nice package of 'high quality pure Chinese tea'? So engineer Liu put one qualified builder with a dozen peasants, to train them to build brick walls, work with cement, etc., while the most teachable among them were entrusted with learning welding. This Mao Zedong 'Great Leap Forward'-style technique to transform agrarians into a working class in a short period more or less worked for our enterprise - but with some ongoing disturbances. 
As a precaution to ensure the Chinese team was building what they were contracted for, the local administration hired a Russian engineer, Petrov, and a translator (that was me). We were to control the construction process and ensure that the Chinese brigade understood Russian quality building standards. Engineer Petrov, whom I accompanied in search of Chinese construction faults, had the habit of appearing at the end of the working day to check the quality of the work done that day. He played a very strange game. He would try to destroy all of the freshly erected brick walls by heaving with his huge shoulders and massive body, sometimes even using a big hammer as well. This was his personal way to test the strength of the Chinese construction. The Chinese workers and I were shocked to see how easily a Russian engineer could destroy the freshly built walls. Mr Liu, the Chinese engineer, seemed deeply insulted. He required an explanation from the Russian, asking me, 'Why does he destroy our work?' Petrov answered, as far as I remember, something like:

I know you Chinese are sly people. Even if you do a good job today, it doesn't mean that tomorrow you will be as good as today. If I trust you, you will think that I'm stupid, and you will try to cheat me again.

In this situation distrust was a necessary exercise for the Russian engineer, an appropriate caution to stimulate the Chinese workers to perform their work better; breaking down the walls was his way of showing that their quality was not satisfactory.

The Chinese workers immediately started saying to each other, ' $t a \mathrm{bu}$ kekao women' ('He found [us] unreliable'), but without any strong emotion or anger. It was as if they somehow admitted that they could not be fully trusted to build this plant, seeing themselves not as professional builders but as people who would prefer to grow vegetables. As far as I could see, the only person who became very nervous about this demonstration of distrust was engineer Liu. He was worried that these violent quality checks would slow down the work schedule. His interest was to build the meat processing plant according to contract as soon as possible. To speed up the process, engineer Liu had told his construction team to lay single brick walls instead of double brick walls (as should have been done according to the construction design to make the building stand firmly). Instead of reinforcing the walls by installing a strong metal armature, the Chinese team just put metal sticks into the cement without welding them to one another or fixing them to the whole construction. 
Here we see that two sides had conflicting interests and expectations: the Chinese engineer was interested in quick project performance without concerns about quality, while the Russian engineer was interested in good quality results rather than a short project schedule. So to progress with the construction both sides somehow needed to take each other's interests into consideration, but it was Chinese engineer who had to change his attitude most, since he wanted to continue the profitable contract with the Russian side.

To take quality into consideration, Liu rescheduled the work: his team started laying bricks in the evening and night to have more time during the next day for the bricks to glue together and fix the structure firmly. But engineer Liu was not about to give up his interests, and he still wanted to keep the high speed of the construction process despite some quality improvements. He said his team would weld the carcass to each second metal armature pole. But the Russian engineer soon discovered that the armature was not properly fixed when one day he made a hole in a wall using his hammer.

The two engineers, both experienced and knowledgeable - a Russian and a Chinese - could read each other's mind without a single word for me to translate. When all tricks had been exhausted and after such cruel trust-distrust tests, the Chinese quality slowly but gradually improved and the Russian and Chinese engineers started showing each other some signs of warming and even sympathy: their handshakes became more cordial, and a pint of beer at the end of the working day symbolized that the Chinese work had passed the quality check. Moreover, the Russian engineer became very popular with the Chinese team: they anticipated his evening wrestling performances and even placed bets on whose wall would remain standing after Petrov's shoulder and hammer work. They admired the Russian engineer for his physical strength and respected his distrust; they even asked him to take pictures with them to express their sympathy.

However, although the Russian engineer's distrust 'softened' and progressed to more trusting relations with the Chinese construction team, Petrov was not eager to continue his fight for better quality, since he was now more or less satisfied with the work and engineer Liu had finally passed his test - only to be challenged by another task, which required more mutual trust. Petrov decided to invite Liu to rebuild his own private house by extending a part of it. As a precaution, Petrov warned engineer Liu in a very direct manner,

Listen here (slushai syuda), Liu! You still can do bad work at the meat processing plant - I'll close my eyes to that - but not in my house. Do you understand me? 
And for the next ten days engineer Liu spent his time rebuilding the private house of his Russian partner using building materials stolen from the meat processing plant and the labour of a dozen of his workers relocated from there. Perhaps that was the price for the agreement between Petrov and Liu, that Petrov would tolerate the still-dubious quality and thefts at the meat processing plant. Now he had yet another idea about how to use the Chinese labour in his own interest, and for that he needed to build more trustworthy personal relations with engineer Liu - indeed, to make a secret private deal with him.

When the meat processing plant was almost finished and only a few skilled workers were left to deal with the electricity and final wall plastering before preparing the ground to install the equipment, Liu and Petrov decided to (mis)use the excess non-qualified Chinese labour and exploit them for their own profit by 'selling the Chinese workers', i.e. leasing them to other construction sites. So an obvious regrouping of their interests had taken place. This resulted in 'encapsulating' their interests to make additional profit, if we refer here to Russell Hardin's idea about making 'encapsulated (separate) interests' subject to a joint common interest as a condition for building trusting relationships (Hardin 2002).

As an interpreter, I was called upon to assist with the leasing of personnel' to various sites and private properties as arranged by engineer Petrov. Here Chinese workers dug construction pits, repaired houses, fenced fields around farms, etc. The Chinese workers were actually glad to do these temporary reshuffles, since it gave them an opportunity to travel around a bit and see other places besides the meat processing plant in which they had been locked since their arrival in Russia. The only thing that disturbed them was that engineers Petrov and Liu did not pay them for the additional jobs. They felt literally exploited. This situation gave grounds for tensions and distrust, but this time within the Chinese group itself: between the Zhejiang peasants and engineer Liu and his small 'gang'. The groups stopped eating meals together, and both groups wanted to get my sympathy and support. The Zhejiang group hoped that I would leak some information about Liu's share in Petrov's deals to his new customers; Liu's 'gang' hoped that I could tell them how much Petrov got from his clients for the work. As for engineer Petrov, he didn't care about the Chinese at all, since he was in the position of power to decide how much of their profits to share with engineer Liu, and it was not Petrov's business to worry whether Liu paid his compatriots from his share or not.

I could see how vulnerable these Zhejiang peasant were during their work contract in Russia: with no language to make requests, no voice to 
express their concerns and lodge complaints, no rights with which to defend themselves, no one in whom they could trust, and even without their documents that would allow them to quit the job and go back to China. Not to mention their high injury rates when they were learning how to work at heights and construct scaffolding. Perhaps it was much better for them in terms of group solidarity when their laoban ('boss'), engineer Liu, had been playing on their side against the Russian engineer. But the situation changed: their boss betrayed them and changed sides by making a deal with engineer Petrov. The Zhejian group then found themselves in a crisis, this time about their growing distrust vis-à-vis their co-ethnics.

Obviously, the Zhejiang peasants had been victimized several times: firstly by the Chinese and Russian middlemen companies, starting from the recruitment agency in Manzhouli and continuing when they were forced to do work that they were not recruited for (e.g. construction instead of agricultural work); and secondly, when an element of coercion was introduced and they were forced by another Chinese to do extra work without proper (or any) payment. All of this allows one to talk about the criminalization of Chinese labour in Russia and even elements of human trafficking and smuggling (according to United Nations definitions ${ }^{21}$ ), since the practice brings illicit profits for the traffickers/smugglers (or coyotes, to use the terminology of the US-Mexican border) and other people involved in the misuse of Chinese labour in Russia.

\section{The Emergence of Distrust in Co-ethnic Ties and the Criminalization of Chinese Labour in Russia}

Sociologists and diaspora studies researchers put much effort into exploring why many immigrants rely so heavily on ethnic-based social capital, especially at the outset of migration and during the period of settling in (Mahler 1995; Nee and Sanders 2001, Habyarimana, Humphreys, Posner, and Weinstein, 2009). Although there are obvious advantages offered by

21 The United Nations defines human trafficking as the recruitment, transportation, transfer, harbouring, or receipt of persons by improper means (such as force, abduction, fraud, or coercion) for an improper purpose including forced labour or sexual exploitation. Human smuggling is a related but different crime, which generally involves the consent of the person(s) being smuggled. These people often pay large sums of money to be smuggled across international borders. Once in the country of destination they are generally left to their own means. For more details, see UN Protocol to Prevent, Suppress, and Punish Trafficking in Persons: https://www.unodc.org/ unodc/en/human-trafficking/what-is-human-trafficking.html. 
co-ethnic ties, such as confidential relations based on common language, ethnic solidarity, and sharing knowledge to reduce risks as they adapt to the host society, at the same time this trust in ethnic ties puts many migrants in dependent positions. Ethnic entrepreneurs often use this resource in their own interests and make servitude a part of diaspora lives, usually by employing newly arrived co-ethnics in low-skilled and low-wage positions and locking them into the diaspora enclave ethnic economy. The result is internal conflicts and inequality, as Sarah Mahler (1995) illustrates in her research on the exploitation of Salvadorian migrants in the US by their coethnics. Similar situations of inequality within diaspora groups, such as the Chinese and Vietnamese in the US described by Victor Nee and Jimy Sanders (2001), support my view that co-ethnic abuse among Chinese working in Russia is not exceptional. Surprisingly, this phenomenon among migrants in Russia, particularly within the Chinese diaspora, has not yet been the focus of scholarly interest, which still mostly focuses on the economic and security aspects of Chinese migration to Russia (Alexeeva 2008; Wishnick 2008; Larin 2009; Datsyshen 2008; Dyatlov 2011; Gulina 2015).

Here I will change scale from the particular case I presented in the previous section to introduce the almost 'industrial scale' of the misuse and smuggling of Chinese labour into Russia. This discussion is based on my recent fieldwork and interviews with Chinese entrepreneurs who 'trade' their co-ethnics in the thousands between construction companies operating not only in Eastern Siberia but all over the Russian Federation. Since the 1990s, these 'soul trading' schemes have progressed and became more sophisticated. Chinese entrepreneurs widely employed the ploy during the 200os, during the peak of the demand for foreign labour in Siberia and the Russian Far East.

In recent years, I have been introduced to several Chinese entrepreneurs in Eastern Siberia who were involved in the construction and service sectors, and who along with legal businesses engaged in many shadowy activities. One of them, Victor Chinovich Dagunov (his original Chinese name was Gen Fudong), ${ }^{22}$ has Russian citizenship acquired through his marriage to a Buryat woman from Ulan-Ude city. He speaks perfect Russian and is considered to be the unofficial head of the Chinese diaspora in Buryatia, and he mediates all conflicts involving Chinese business in 'his' territory.

22 According to the local rumours, he took name 'Victor' because he considers himself to be successful and victorious. His patronymic name 'Chinovich' (otchestvo) derives from 'China' to indicate that he is still a son of China. And he adopted his wife's surname 'Dagunov' as his new Russian surname. 
Dagunov arrived in Russia in the mid-199os when the Tianjing city government signed a contract with the Buryat Republic government to send a Chinese construction company to build social houses using public funds. After this project, Dagunov established his own construction business while remaining a representative of the Tianjin state-run construction company, which was considered more trustworthy than the private ones. In contrast to other Chinese, who started their businesses in Russia from scratch, Dagunov enjoyed a high starting position secured by the intergovernmental agreement between Tianjian city and the Buryat Republic. This opened doors for him to build guanxi ('personal relations') with many local officials. But he still had to overcome the general mistrust of 'the Chinese' in Russia. To give the impression that his business was locally rooted, he placed his Russian-citizen wife and her numerous relatives prominently as its public façade, and this indeed made his enterprises look more trustworthy to the locals.

A quick internet search shows that Dagunov owns over a dozen commercial companies involved in construction, mining and agriculture, such as Udastroinvest (Uda Construction \& Investment), Akademzhilstroi (Construction of Housing and Apartments for the Buryat Branch of the Russian Academy of Sciences and its employees), Vostokstroi (Orient Construction), Atlant, Dupon-Invest, Agro-B, SMIR, Ivolginskoe, and Prigorodnyi, to name but a few. ${ }^{23}$ His name and companies are associated with numerous scandals, lawsuits, and complaints about the bad quality of the apartment buildings, as well as long delays in commissioning them for hand-over, despite the fact that the purchasers had paid for their apartments and thus participated in co-funding the construction known in Russia as dolevoe stroitel'stvo To avoid legal punishment, paying penalties for delays, and having to correct the faults in his companies, he prefers to declare bankruptcy - and then open a new company with a 'clear' history to reset his business (see Humphrey, this volume).

Suspicion and rumours about the bad quality of his 'Chinese houses' follow him like a long plume in the region, but nevertheless still allow him to stay afloat. As the owner of another construction company in the region told me, most of Dagunov's profit comes from trading Chinese labour to other construction companies thanks to his agricultural companies (e.g.

23 See the list of the All-Russia business enterprises http://www.catalogfactory.org/fnd.php?f io $=\%$ Do $\% 94 \%$ Do $\%$ Bo\%Do\%B3\%D1\%83\%Do\%BD\%Do\%BE\%Do\%B2\%20\%Do\%92\%Do\%B8 \%Do\%BA\%Di\%82\%Do\%BE\%Di\%80\%20\%Do\%A7\%Do\%B8\%Do\%BD\%Do\%BE\%Do\%B2\%D о $\%$ B $8 \% \mathrm{D}_{1} \% 87$ 
Figure 3 Advertisement for job vacancies in Russian border cities, Manzhouli commercial press, 2013

\begin{tabular}{|c|c|c|c|}
\hline \multicolumn{4}{|c|}{ 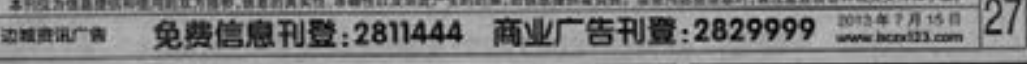 } \\
\hline 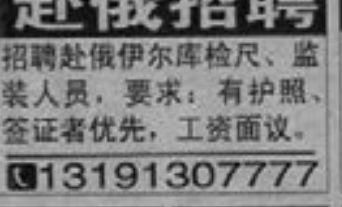 & 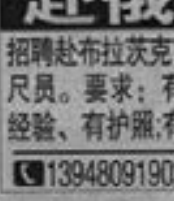 & 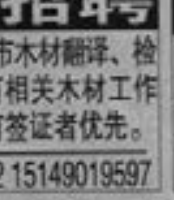 & 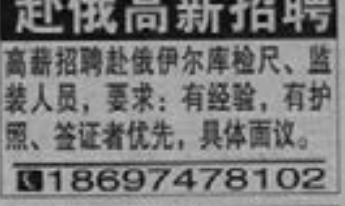 \\
\hline 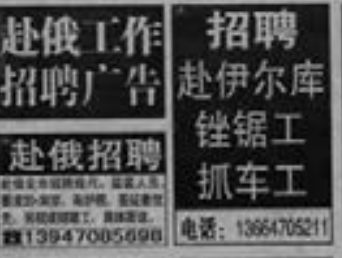 & 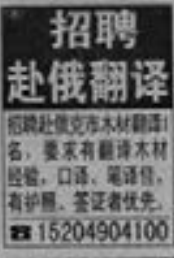 & 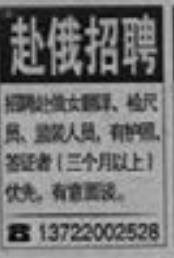 & 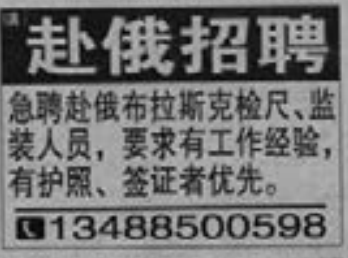 \\
\hline 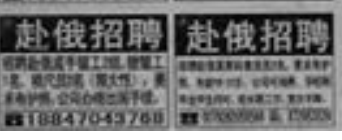 & 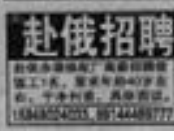 & 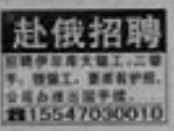 & 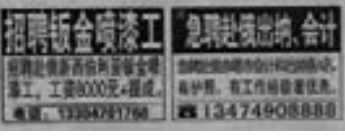 \\
\hline
\end{tabular}

Agro-B, SMIR, Ivolginskoe, Prigorodnyi, etc.), which provide the visas and 'employment contracts' to bring Chinese workers to Russia.

Apart from this agricultural scheme, many Chinese laborers come to Russia on group tourist visas issued for periods from one week to 30 days; after overstaying their visas and working illegally for several months until the construction season is over, i.e. when winter starts, the Chinese 'tourists' return to China. This scheme actually confirms the thesis that Chinese migration to Russia is predominantly short-term in intention and seasonal in character (Wishnick 2008; Larin 2009), which brings up the question: why do Russians speak of a Chinese migration threat, if these workers return home at the end of their contracts?

Labour is recruited through employment agencies across China that advertise job vacancies in Russia (Figure 3); freshly recruited 'tourists' with clear (or cleared) documents arrive for the next working season in Russia with a quasi-legal visa status. A typical contract covers return travel expenses, accommodation and meals in exchange for the commitment to work 10-12 hours per day, six days a week.

To change scale again, this situation also raises many questions at the level of the state. How trustworthy are the official figures that declare a 51 percent rise in Chinese tourists visiting Russia, reaching 537,000 in 2015 on 
group visas? ${ }^{24}$ What proportion of these are actually labour migrants? And how honest is the Chinese government in initiating its ever-more 'China friendly' visa-free border-crossing regime between Russia and China, when in return a Chinese 'tourist group' can consist of only three persons and stay in Russia for up to 21 days?25 Maybe exporting labour to Russia is one of the many ways of defusing the tensions caused by excessive labour in the Chinese domestic market, and of supporting entrepreneurship by sending managers abroad. Since 2005 a special state labour policy has been expanding the legal and quasi-legal opportunities for Chinese to work abroad. It seems that the concept of hubuxing ('economic complementarities') ${ }^{26}$ has been developed by Chinese policymakers to support labour out-migration, ${ }^{27}$ especially, in the Russian case, of poorly trained workers, since qualified Chinese workers have much better opportunities elsewhere.

I gained some insight into the relations between Chinese state officials and workers in my conversations with Mr Huang, a representative of the Chinese Embassy in Moscow. We discussed the incident in Bil'chir village, and Mr Huang went on to mention the emergency telephone calls he received - among them calls from Chinese workers who had not been paid at all for months after their Chinese middlemen companies disappeared with the money received for contracts. They had left their co-ethnics not only without wages, but also without their passports to return to China, locked in barracks somewhere on the outskirts of industrial sites. The Chinese Embassy had to make their own investigation: how had these workers entered Russia, who had their passports, how could they get the passports back to send the workers back to China, and, finally, who would pay for their travel home? According to Mr Huang, tracing the chain of these transactions between companies is very difficult and almost impossible. As an example, Mr Huang recalled a case when mainland Chinese

24 Data accessed from official website of the Russia-China Tourism Association http:// visit-russia.ru/news/pochti-polmilliona-bezvizovyh-turistov-iz-kitaya-posetili-rossiyu-za9-mesyacev-2015-goda and Gazeta news agency reports here http://www.gazeta.ru/business/2016/03/27/8143115.shtml.

25 Although this Agreement is not yet signed, a spokesperson of the Russian Tourism Agency (Rosturism) is sure that it will be ratified during the next official visit of President Putin to China in summer 2016. Retrieved from http://www.gazeta.ru/business/2016/03/27/8143115.shtml.

26 http://china.org.cn/archive/2004-08/03/content_1102908.htm, http://news.xinhuanet.com/ world/2007-08/22/content_6582041.htm. The 'concept of economic complementarities' (互补性) between Russia and China recognises that Russia has land and natural resources, but suffers from a shortage of labour in the regions bordering China, while China lacks land and resources but has rising demographic pressure and an oversupply of labour.

27 http://www.china.org.cn/english/BAT/124429.htm 
workers arrived in Russia through a Malaysian construction company run by Malaysian ethnic Chinese, who then 'sold' them to a Russian construction company operating somewhere in Tatarstan. In this case, one of the employers confiscated the legal immigration documents, thus making the Chinese employees dependent on them and vulnerable. Unlike other cases of migrants tied into low-skilled and low-paid jobs in the co-ethnically run economy, such as workers from Central Asia, Chinese workers in Russia do not plan to stay illegally in Russia in the long-term, nor do they tolerate mistreatment from their naturalized co-ethnics. In these situations they often seek redress by appealing to the Chinese embassy or consulates (to people like Mr Huang, who are on duty to respond to such calls), which, as they believe, should protect them in a foreign country. However, this trust-of-last-resort can be misplaced. Chinese labour migrants become a concern to the Chinese authorities and their overseas missions only if the case involves diplomatic problems or large social conflicts publicized in the media, such as the case in Bil'chir. ${ }^{28}$ In smaller or individual cases Chinese officials prefer not to be involved in resolving migrants' problems. All of this shows that some degree of mistrust is the appropriate response to the actual situation on three scales: that between workers and employers, between the employment agencies and the state, and between state officials and the workers in trouble.

28 For example, Russian media recently reported another case of mass abuse of Chinese workers. Accessed from http://www.kp.by/daily/26401.4/3277450/. After being unpaid for three months, nine hundred Chinese workers at the Dobrush paper mill factory in Gomel'sk oblast in Belorussia delegated their activist group of 70 people to contact the Chinese embassy in Minsk to call the Ambassador to come to Dobrush to help them to sort out their local problems with a Chinese company, which contracted them and delayed payment. The Embassy responded only in July 2015, when the Belorussian press started reporting about three hundred exhausted and thirsty Chinese workers marching along the highway from Dobrush district to the regional city of Gomel. They had been stopped and accompanied by local police only when they continued their $300 \mathrm{~km}$ march from Gomel to the capital city of Minsk to reach the Chinese Embassy and to hand over their petition of complaint. Only when the Chinese 'revolt' heated the local press and the local authorities in Dorbush and Gomel involved police for security reasons, did Chinese Ambassador Cui Qiming appear to meet his compatriots to hear about their problems. Actually this story also confirms the pattern of behaviour of Chinese peasants (who comprise most Chinese labour and have economic incentives to work in Russia) discussed in scholarship concerning their high political trust in the Central government (represented in this case by the Chinese embassy in Minsk), and their demands to punish bad local Chinese entrepreneurs and to protect their rights and lives, expecting quick and just resolution from the Chinese state by personally appealing to an 'imperial envoy'. This general tendency of Chinese peasants to believe that the Centre is more trustworthy than all lower institutions was discussed in a number of scholarly articles on political trust in rural China (Li 2004; Tong 1998). 


\section{Distrust as Modus Vivendi and Modus Operandi: Concluding Remarks}

Chinese and Russian relations are still far from being 'stress-free' despite the official policy of 'Good Neighborliness, Friendship and Cooperation'29 that provides a political frame to build some degree of cooperation and joint business. Increased human mobility, including cross-border tourism and trade, semi-legal and illegal smuggling of labour, and disregard in the use of natural resources cause additional human tensions, adding to the existing wide spectrum of distrust (historical, political, and habitual distrust of those outside the trusted group, etc.). In consequence, we see a range between 'hard' and soft' distrust that still allows both sides to function and benefit in the absence of trust. Moreover, both sides face new challenges and need to secure risks in relation to a neighbouring country 'in close geographic proximity, but vast cultural distance' (Larin 2005, 48). With regard to trust, cultural differences between Russians and Chinese are seen in the moral categories mentioned earlier (the vocabulary of doverie and xiangxin, xinyong and kexin), and also in the practical relational ideas (guanxi and blat) that businessmen actually use. Mistrust, on the other hand, comes up less as an abstract idea than in reference to actual concrete incidents, e.g. those involving the violation of Chinese business interests and attacks on Chinese in Russia: 'police, customs and skinheads are the main three sources of potential threats for Chinese in Russia. ${ }^{30}$ These three concrete threats are sources of distrust ultimately caused by the Russian domestic situation itself: malpractices in the emerging Russian market, weak state institutions, corruption in the police and customs, extreme forms of Russian nationalism with racist and anti-migrant sentiments, etc. In addition, I have tried to shed light on situations in which distrust arises from co-ethnic conflicts and tensions among the Chinese, thus adding threat number four to the three above-mentioned 'threats in Russia' as seen from China.

Even without these historical and present-day encounters of mutual distrust, Russia and China themselves are societies with a low level of trust in state institutions. It has been argued that this is due to the fact that these countries were ruled for most of their history through the

29 A Treaty for Good Neighborliness, Friendship and Cooperation signed by Russia and China in 2001.

30 “警察已经同 海关和光头党一起’ accessed from http://world.people.com.cn/GB/14549/ 3406738.html 
personal power of the Emperor or Tsar, with hostile environments for business and entrepreneurship (Radaev 2004, Kononenko and Moshes 2011 on Russia; Khodyakov 2007 on the USSR; Bodde and Morris 1973, Kiong and Young 1998, and Li 2004 on post-reform China). According to these arguments, the implementation of law in such societies was subject to the personal definition of the Emperor/Tsar while officials at all levels were responsive to bribery. ${ }^{31}$ This bred a deep sense of distrust in institutions involving officials, thus leaving them weak and insufficient, supplanted by an abundance of informal practices. Nowadays a similar deficiency in legislation and the low-trust environment in both countries are used by Russian and Chinese business circles to create informal institutions (guanxi- and blat-based) to benefit from the 'good neighbourhood' policy and the more open border-crossing regime (e.g. by smuggling Chinese labour). Straightforward cheating one another of the kind seen in 19th century Kyakhta may perhaps be less prevalent today, but nevertheless the stories I have described are evidence of what I have called 'soft distrust'. And this 'functional mistrust' operates not only at the individual level, but also at the level of the state, when competitive governments (Russia and China in our case), seeking economic 'complementarities', take advantage of each other's loopholes and institutional weaknesses. Thus distrust in all its varieties and grades appears to be both a modus vivendi and a modus operandi for living in good neighbourhood with a country with a similar distrust landscape.

\section{Acknowledgements}

The research for this article was carried out as part of 'Where Rising Powers Meet: China and Russia at their North Asian Border', a three-year project run at the University of Cambridge (2013-2015) and funded by the Economic and Social Research Council, UK. For more information, see www.northasianborders.net. I also would like to acknowledge the generous support offered by International Institute for Asian Studies (IIAS, Leiden), which granted me six months of funding in 2016 to focus on writing up and final revisions.

31 For analysis of a similar situation of distrust in European absolute monarchies of the 17th century, see Geoffrey Hosking (2010, 30-31). 


\section{References}

Alexeeva, Olga, 2008. Chinese migration in the Russian Far East. China Perspectives, 2008(3), pp. 20-31.

Bagashev, Ivan. 1898. Newspaper Baikal. Issue 15 June 1898.

Bodde, Derk, and Clarence Morris, 1973. Law in Imperial China: Exemplified by 190 Ch'ing Dynasty Cases. Philadelphia: University of Pennsylvania Press.

Cherepanov, Sergei, 1867. Puteletatel'i ego pis'ma: Obozrenie Rossii s ptichego poleta [Flyer and his letters: Bird's-eye view on Russia]. Kazan': Tilli Publishing House.

Corsin Jimenez, Alberto, 2011. Trust in anthropology. Anthropological Theory, 11(2), pp. 177-196.

Dasgupta, Partha, 1988. Trust as a Commodity. In Diego Gambetta (ed.), Trust, Making and Breaking Cooperative relations. Oxford: Basil Blackwell. pp. 49-72.

Datsyshen, Vladimir, 2008. Kitaitsyv Sibiriv 17-20 vv.: problem migratsii I adaptatsii [Chinese in Siberia in 17th-2oth centuries: migrations and adaptations]. Krasnoyarsk: Siberian Federal University.

Donnan, Hastings, 2010. Ethnography, security and the 'frontier effect' in borderlands. In Hastings Donnan and Thomas M. Wilson (eds.), Borderlands: Ethnographic Approach to Security, Power, and Identity. University Press of America: Lanham, pp. 1-20.

Dyatlov, Victor, 2011. Kitaiskie migrant i obraz zheltoi opasnosti: possiisky variant obschemirovogo sindroma? [Chinese migrants and fear of the Yellow Peril: Is it a Russian version of the global sinophobia?]. In Victor Dyatlov (ed.), Vostok Rossii: migratsii i diaspory v pereselencheskom obschestve. Rubezhi 19-20 i 20-21 vekov [East of Russia: Migrations and Diasporas in the Societies on the Move] . Irkutsk: MION, pp. 461-479.

Filippova, Lubov' (ed.), 2005. Kyakhtinskaya starina [Kyakhta in the days of old]. Ulan-Ude: Ministry of Culture of the Buryat Republic.

Gambetta, Diego (ed.), 1988. Trust: Making and Breaking Cooperative Relations. Oxford: Blackwell.

Gulina, Olga, 2015. Myth of the Chinese migration to Russia: irrational fear of the global dimension of Chinese migration. Intersection, 11 August. http:// intersectionproject.eu/article/russia-world/myth-chinese-migration-russia.

Haas, Paula, 2010. Trusting Everyone and No-one: Constructing the Ideal Barga Society in Inner Mongolia. PhD Thesis, University of Cambridge.

Habyarimana, James, Macartan Humphreys, Daniel N. Posner, and Jeremy M. Weinstein, 2009. Coethnicity and Trust. In Karen S. Cook, Margaret Levi, and Russell Hardin (eds.), Whom Can We Trust? How Groups, Networks, and Institutions Make Trust Possible. Russel Sage Foundation: New York, pp. 42-64. 
Hardin, Russell, 2002. Trust and Trustworthiness. Russell Sage Foundation: New York.

Hardin, Russell, 2003. Gaming Trust. In Elinor Ostrom and James Walker (eds.), Trust and Reciprocity: Interdisciplinary lessons from experimental research. Russel Sage Foundation: New York, pp. 80-101.

Hosking, Geoffrey, 2010. Trust: Money, Markets and Society. Seagull Books: Calcutta. Larin, A.G., 2009. Kitaiskie migrant v Rossii [Chinese migrants in Russia]. Moscow: Vostochnaya kniga.

Larson, Deborah Welch, 2004. Distrust: Prudent, If Not Always Wise. In Russell Hardin (ed.), Distrust. Russell Sage Foundation: New York, pp. 34-59.

Levi, Margaret and Laura Stoker, 200o. Political Trust and Trustworthiness. Annual Review of Political Sciences, 3, pp. 475-507.

Li, Lianjiang, 2004. Political Trust in Rural China. Modern China, 30(2), pp. 228-258. Khodyakov, Dmitry, 2007. Trust as a Process: A Three-Dimensional Approach. Sociology. Volume 41 (1): 115-132.

Kipnis, Andrew B., 1997. Producing Guanxi: Sentiment, Self, and the Subculture in a North China Village. Durham, N.C. and London: Duke University Press.

Kononenko, Vadim and Arkady Moshes (eds.), 2011. Russia as a Network State: What Works in Russia When State Institutions Do Not? Palgrave Macmillan: UK. Mahler, Sarah J., 1995. American Dreaming: Immigrant Life on the Margins. NJ: Princeton University Press.

Namsaraeva, Sayana, 2012. Saddling up the Border: A Buriad Community within the Russian-Chinese Frontier Space. In Zsombar Rajkai and Ildiko Beller-Hann (eds.), Frontiers and Boundaries: Encounters on China's Margins. Wiesbaden: Harrassowitz Verlag.

Nee, Victor and Jimy Sanders, 2001. Trust in ethnic ties: social capital and immigrants. In Karen Cook (ed.), Trust in Society, pp. 374-392.

Nye, Joseph S., 2015. A New Sino-Russian Alliance? Project Syndicate, 12 January.

Quested, Rosemary K.I., 2014. Sino-Russian relations: a short history. Routledge: Taylor \& Francis Group.

Radaev, Vadim, 2004. Coping with Distrust in Emerging Russian Market. In Russell Harding (ed.), Distrust. Russell Sage Foundation: New York, pp. 233-248.

Subbotin, A.P., 1892. Chai i Chainaya torgovlya v Rossii i drugikh gosudarstvakh: proizvodstvo, potreblenie iraspredelenie chaya [Tea and Tea Trade in Russia and other states: production, consumption and distribution]. St. Petersburg: izdanie A.G. Kuznetsova.

Tong, Chee Kiong and Pit Kee Young, 1998. Guanxi Bases, Xinyong and Chinese Business Networks. The British Journal of Sociology, 49(1), pp. 75-96.

Toussaint-Samat, Maguelanne. 1992. History of Food. Cambridge, MA: Blackwell. 
Trusevich, Khristofor. 1882. Posol'skie i torgovye snosheniya Rossii s Kitaem (do 19 veka) [Diplomatic and Trade Relations between Russia and China (till the $19^{\text {th }}$ century). Moscow: Tipographiya G. Malinskogo.

Ulmann-Margalit, Edna, 2004. Trust, Distrust and In Between. In Russell Hardin (ed.), Distrust. Russell Sage Foundation: New York, pp. 6o-61.

Wishnick, Elizabeth, 2008. The securitization of Chinese Migration to the Russian Far East: Rhetoric and Reality. In Melissa Curley and Wong Siu-lun (eds.), Migration and Securitization on East Asia. New-York: Routledge Press, pp. 83-99. Yamagishi, Toshio, 2003. Cross-societal experimentation on Trust: A comparison of the United States and Japan. In Elinor Ostrom and James Walker (eds.), Trust and Reciprocity: Interdisciplinary lessons from experimental research. Russell Sage Foundation: New York, pp. 352-370. 


\title{
Economies of Trust
}

\author{
Informality and the State in the Russian-Chinese \\ borderland
}

Tobias Holzlehner

Humphrey, Caroline (ed.), Trust and Mistrust in the Economies of the China-Russia Borderlands. Amsterdam: Amsterdam University Press, 2018

DOI: $10.5117 / 9789089649829 / \mathrm{HOLZ}$

\begin{abstract}
Focusing on small-scale, cross-border trade between China's Heilongjiang Province and Russia's Primorye Region, this chapter explores the intricate relationship between individual economic strategies, trust, and the state from an ethnographic perspective. Investigating the paramount role of trust in informal economic operations, I argue that shifting intensities in people's loyalty ties have created new forms of economic cooperation that transcend the logic of a national economy. Informal economic solutions, based on personal trust networks, become an alternative to the loyalty ties involved in the trust of the state and its institutions. Trust embedded in often shady enterprises seems to be a counterweight for the lack of trust in official structures and mechanisms. The seemingly paradoxical situation of the simultaneous existence of low levels of systemic trust and high levels of interpersonal trust is thus two sides of the same coin, indicating a subtle shift away from loyalty to the state towards networks of interpersonal loyalties.
\end{abstract}

Keywords: Russia, China, informal economy, cross-border trade, trust, corruption, Vladivostok

\section{Introduction}

In his 2001 article 'Welcome to the Seventeenth Century,' Charles Tilly predicts a return of network-based organizational forms of global business enterprises in the upcoming decades (Tilly 2001). Arguing that risky longterm enterprises need stable networks of trust, he envisions a weakening 
of the established links between centralized, consolidated states on the one hand and bounded firms protected by guarantees given by the state on the other hand. According to Tilly, the state-backed stabilization of property and trade established since the 18th century - as well as the risk-absorption through governments especially prevalent under state socialism - are waning, increasingly replaced by the 're-emergence of autonomous trust networks' (Tilly 2001, 205). Tilly is not alone in his assessment of the upcoming regime shift in the global economy, as several other scholars have discussed the dawning of a new, network-based millennium that will have fundamental effects on business organizations (Castells 1996; van Dijk 1999; Malone and Laubacher 1998; Rifkin 200o). This also seems to imply a shift in loyalties, from the nation state to new forms of dependabilities.

I would like to add a view from below (and afar) to this debate by taking this hypothesis to the Sino-Russian border, where a seemingly paradoxical situation has emerged: low trust and confidence in state structures and agents coexist with, and are counterbalanced by, a high-trust milieu of informal economic strategies that has developed in this cultural and economic borderland during the last 20 years. Focusing on small-scale, cross-border trade between China's Heilongjiang Province and Russia's Primorye Region, I explore in the following pages the intricate relationship between economic strategies, trust, and the state. By investigating the paramount role of trust in informal economic operations, I argue that shifting intensities in people's loyalty ties have created new forms of economic cooperation that transcend the logic of a national economy.

\section{A particular (hi)story of the Russian Far East}

When the Russian geographer and ethnographer Vladimir K. Arsenyev made his way into the snowy mountain valleys of the Sikhote-Alin Mountains north of Vladivostok in the winter of 1906 accompanied by a small expeditionary force, he was surprised and alarmed. As one of the first systematic Russian explorations into the region, Arsenyev's official mission was to conduct scientific and historic research along the Sikhote-Alin mountain range, explore the headwaters of the Ussuri and Iman rivers, and chart the coast north of Olga Bay. Yet his most puzzling finding was the ubiquitous presence of Chinese farmers and fur traders in the backcountry. Alarmed, he remarked: 'In 1906, Russian rule was limited to the Ussuri valley and the coast up to Olga bay. The rest of the country was under Chinese control' (Arsenyev 1926, 73). 
At the end of the nineteenth century, the population of the Amur and Primorye Regions of the Russian Far East was a diverse ethnic mix. Russian settlers, Chinese merchants, Korean farmers, Japanese barbers, Manchurian brigands, and indigenous hunters lived side-by-side in the river valleys and forested mountains of Russia's maritime frontier. Before the Russians established themselves in Primorye, Chinese traders and settlers had dominated the region and monopolized the trade with the indigenous population, leaving little room for small Russian businesses. Chinese fur merchants had established a system of debt peonage and exploitation, forcing indigenous communities into compliance with the traders' demands (Landgraf 1989, 506).

The resource-rich Russian Far East, especially the Primorye, has its own particular economic history, which is closely connected to its rare flora and fauna that was and still is highly valued and priced in China. During the 19th century, the harvesting and gathering of plants and animals for culinary and medicinal purposes was a profitable activity for many Chinese seasonal workers. Arsenyev estimated the annual number of Chinese ginseng collectors in the Ussuri region to be around 30,000 at the beginning of the twentieth century (Arsenyev 1914, 123). Along the coast, Chinese trepang ('sea cucumber') collectors were also highly active. Before 186o, Vladivostok's bay had been a popular gathering ground for sea cucumbers, hence its Chinese name Hai-Shan-Wei (Sea Cucumber Bay). During the summer, Chinese fishermen set up camps along the shores of the bay and retreated at the beginning of winter with their valuable catch to Chinese ports.

The lack of Russian state control in the Priamur and Primorye Regions, especially in the remote areas of the Sikhote-Alin Mountains, created autonomous enclaves that were essentially under Chinese control. However, the profitable economic activities of Chinese trading guilds in the Russian Far East raised the suspicions of the Russian authorities and led to several measures to curb their widespread activities. Arsenyev, for instance, accused these societies of constituting 'a state inside the state [...] independent outposts of China's secret foreign policy disguised as trading and mutual aid societies' (Arsenyev 1926, 181-82). This might be an exaggeration, but nevertheless gives an insight into the extent of the perceived threat to Russian control over the territory. Officially, these Chinese societies were outlawed by Russia in 1897, and yet they existed until at least 1917. The Russian Revolution, which continued until 1923 in the Russian Far East, led to the final dissolution of the Chinese merchant houses and trading societies. The situation of Chinese traders in the Russian Far East then changed dramatically: trading houses were closed and Chinese property 
was confiscated. Many Chinese left the region voluntarily in the following years, and drastic measures were proposed to remove those who remained. For instance, Arsenyev reported to the office of the Far Eastern VKP (AllRussian Communist Party) in 1928:

We don't have time to turn people into Soviet citizens and wait until they change their opinions and characteristics. With our close connections to Manchuria and Korea we have a danger of conflict on our borders with the Korean and Chinese people. The struggle against this includes the possibility of bringing many people from the European part of the USSR and Western Siberia without regard to their nationality. But the Koreans or Chinese must be resettled to the center of our country, and/or to the West and North of the Amur (cited in Khisamutdinov 1993, 119).

Nine years later, Arsenyev's recommendation was rigidly enforced through the complete relocation of the Korean and Chinese population to Central Asia and Manchuria, respectively. Arsenyev did not witness the deportations, as he had died in 1930 at the age of 57 , but his wife had to suffer the changing tides and was swept away by the Stalinist purges in the late 1930s. Accused of being a member of an underground cell of spies and saboteurs allegedly headed by her late husband, she was executed in 1938 after a short trial. The couple's daughter was sentenced to the Gulag five years later.

Arsenyev's life and work not only offers an ethnographically rich insight into the economic struggles of a Russian frontier at the beginning of the 2oth century and gives witness to the perceived threats of Asiatic neighbours, but furthermore it exemplifies the complex and historically rooted relationship triangle between the Russian State, the local Maritime Region, and neighbouring China - a relationship deeply infused with questions of loyalty and distrust. Suspicion of China, as well as of local elites, permeate the history of Russian centre-periphery relations. In this case, Arsenyev questioned the loyalty of Chinese traders and saw them as a threat to the integrity of the Russian state, and yet his own loyalty to the Soviet State was subsequently challenged when his actions were interpreted as undermining this very same integrity.

After the establishment of diplomatic relations between China and the USSR in 1951, trade between Northeast China and the Russian Far East was initiated in the form of a barter agreement between the two countries. Due to eroding state relations, this trade was again discontinued from 1967 to 1983. The late 1980 s brought a normalization of border trade relationships 
with the establishment of an official trade port (Suifenhe-Pogranichnii) and the signing of a national trade agreement. Despite their common interests, the two countries' approaches, and the respective role of each state in facilitating trans-border trade, fundamentally differed from each other. While the Russian government had an essentially hands-off approach, China deliberately tried to use policy measures to stimulate trade between its northeastern provinces and the Russian Far East. From the Chinese perspective, trans-border trade with Russia is classified into distinct categories (Hiraizumi 2010, 3-5). The first category of cross-border trade is referred to as 'Bianjing trade': a system where the Chinese government designates tax preferences to certain regions or cities to conduct foreign trade. 'Bianjing small trade' is a different category, referring to exchanges between trade companies at designated trade ports along the border. 'Hushi trade' designates the trade between private persons inside a specially established border trade zone. These officially registered forms contrast with the so-called 'travel trade': trade that is conducted under the pretext of tourism, with the utilization of informal import channels. Although the boundaries between these different trading categories can be rather fluid, it is important to register that, in contrast to Russia's laissezfaire approach to cross-border commerce, China put a deliberate effort into initiating and spurring trans-border trade with its neighbour by selecting four border cities (Heihe, Suifenhe, Tongjiang, and Manzhouli) to receive a special tax-exempt status in 1992. The direct visible result of these different policies towards border trade is the stark contrast between the bustling boomtowns thriving on trade on the Chinese side of the border, compared to the mostly rural-feeling towns with little trade infrastructure on the Russian side.

\section{Post-Soviet informalities}

The opening of the Russian-Chinese border and the numerous crossings that have been set up since the collapse of the Soviet Union has transformed the face of the Russian Far East as an economic, national, and geopolitical borderland (Figure 4). Citizens in the region are inevitably affected by the increased cross-border commodity flows and labour migration, especially those from China, which have created both economic challenges and opportunities for the local population. In an historic twist, the collapse of the Soviet Union and the reopening of the Russian-Chinese border have led to the re-emergence of the illegal trade in the aforementioned bio-resources. 
Figure 4 Map of the Russian Far East border region

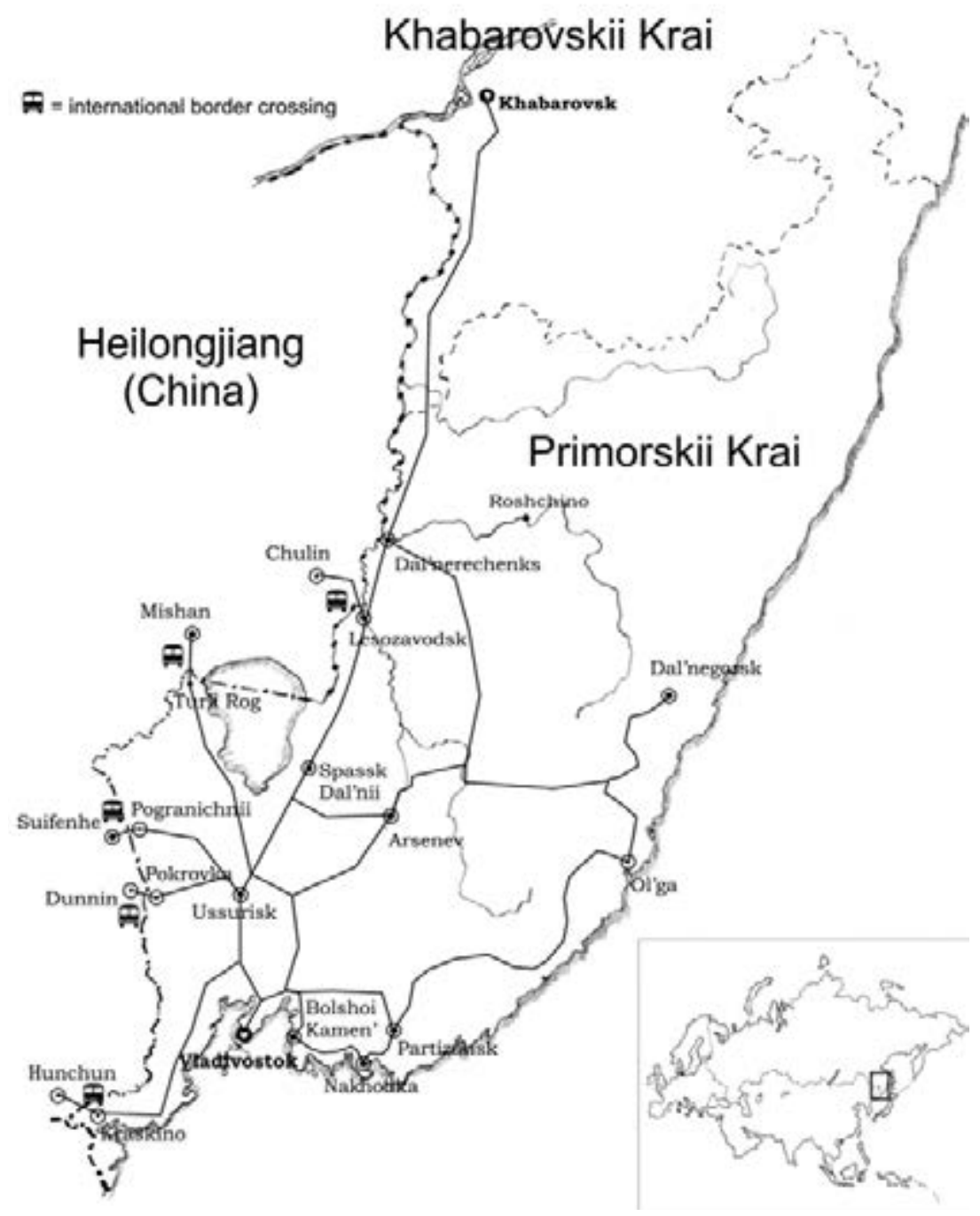

This illegal, lucrative wildlife trade between Primorskii Krai and China is being supported by local poachers and facilitated through Chinese middlemen.

The Chinese culinary and medicinal demand for certain species and the Russian demand for cheap consumer goods have created distinct commodity routes and hubs in the region. For instance, due to its central location and equal distance from the Chinese border, Vladivostok, and the resource rich Sikhote-Alin mountain range, the city of Ussurisk has turned into a centre for 
Figure 5 The border crossing at Hunchun-Kraskino

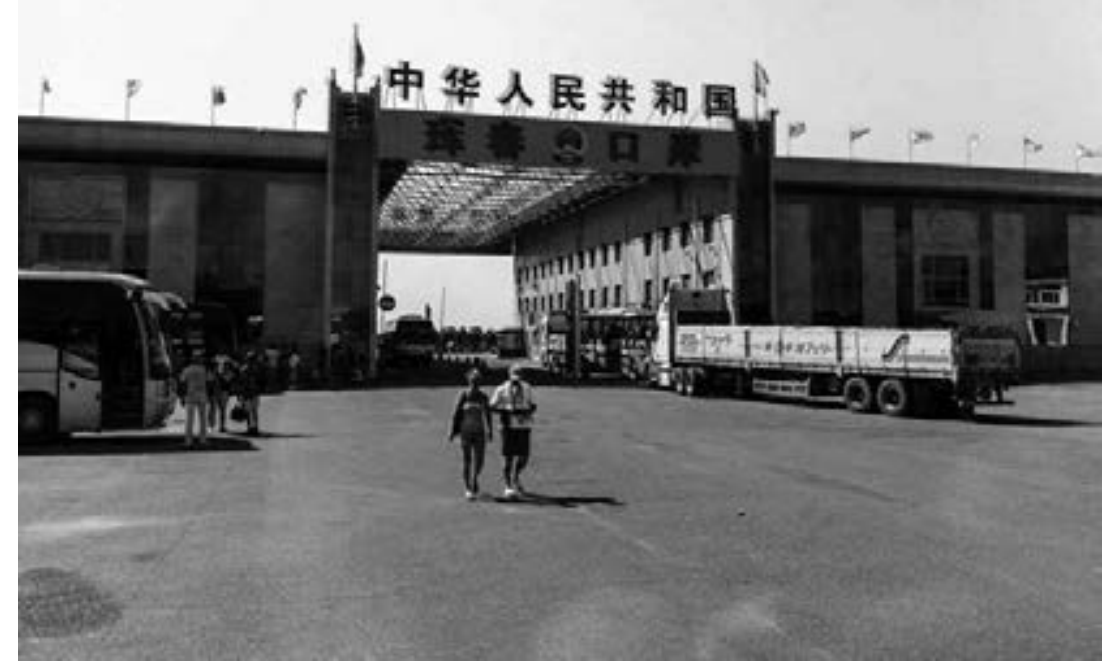

Photo: T. Holzlehner

Chinese middlemen and a major commodity hub for both imports and exports from and to China (see also Park, this volume). Fine distinctions characterize the different border crossings and adjacent Chinese towns. While Suifenhe (Heilongjiang Province) is considered to be a 'wholesale city' with quality goods, its competing border crossing at Hunchun (Jilin Province), 150 miles to the South, is seen as a 'retail city' with relatively lower quality goods, but with a very strong market for bio-resources smuggled out of Russia (Figure 5).

And yet, this specific trade is being dwarfed by other informal markets that deal in higher volumes on a larger scale. Since 1990 various grey economies began to flourish along the borders of the Russian Far East. For instance, the export of scrap metal has become a lucrative business for port cities with large loading facilities, like Vladivostok and Nakhodka. During the 199os and early 200os, Vladivostok's fishing harbour was turned into a large interim storage facility for scrap metal stripped from abandoned Soviet industrial complexes and ships of the Soviet navy and Pacific fishing fleet. During the 1990s, Vladivostok also turned into Russia's hub for the import of used Japanese cars. Vladivostok's proximity to Japan, large port facilities, and 
existing railway links to central Russia made it an almost ideal setting. The large supply of used cars in Japan also satisfied the rising demand for affordable cars in post-Soviet Russia. Although the trade in used vehicles is mostly a legitimate business, it nevertheless presented organized crime syndicates with a variety of opportunities for illegal transactions. Cars could be smuggled into Russia on board cargo liners, thus avoiding import taxes and increasing profit margins; stolen cars endowed with new titles could be sold in the legal used car market. According to Japan's national police agency, illegal trade with Russia was responsible for the theft of 63,000 cars in 2001, with a total estimated value of up to US\$ 2 billion (Kattoulas 2002, 50). Maritime resources represent yet another important source of illicit income in the Russian Far East. Complex schemes of poaching and document fraud involve Russian fishermen, customs officials, and importers from Japan and China - the main destinations for Russia's maritime resources (Williams 2003; Vaisman 2001a).

The informal economies and different actors involved at different points of the commodity flow in the Russian Far East form complex commodity chains. Producers, traders, transporters, middlemen, and consumers are interconnected through both commodity flows and money transfers. For instance, the procurement and trade of sea cucumbers (trepang) form complex sales circuits. Each trepang gathering group includes a diving group of three to four people and additional processors on land. It is common practice for a poacher brigade to sell to a middleman, who resells to a wholesale dealer, who then hires smugglers to transport the merchandise into China for subsequent retail sale. Ussurisk, Dal'nerechensk, and Vladivostok are important wholesale hubs for illegal bio-resources, and also where the packing and shipment of bulk goods are orchestrated. Smuggling routes mostly cross land borders - and Primorsky Krai has five border crossings to China (see Figure 4). As mentioned, Ussurisk, 100 kilometres north of Vladivostok and only two hours from Suifenhe by bus, has become a central hub for trade with China. Ussurisk gives easy access to two border crossings: a combined railroad and road border crossing at Pogranichnii, and a road connection at Pokrovka.

Timber, especially hardwood, is an equally important export of Primorskii Krai. Since the 2000s, Chinese companies have invested substantial amounts of money in the local timber industry for harvesting, processing, and export. During the 2000s, approximately 70 percent of the timber exported from Primorskii Krai to China was considered illegal contraband (Filippovskii 2004). Primorsky Krai is an equally important transit location for commodities originating in China, and functions as a commodity hub for the whole Russian Far East. Wholesale dealers based there deliver 
goods to marginal locations such as Sakhalin Island, the Kurile Islands, or Chukotka, where retail prices are almost twice as high as in Primorsky Krai. The widespread use of small-scale informal cross-border trade in the Russian Far East, locally referred to as chelnochni biznes ('shuttle business'), reduces transport costs and bypasses import taxes (see Introduction). The shuttle trade system was originally based on the legal pretext of a federal resolution from 1 August 1996, which allows private persons to import merchandise up to 50 kilograms and/or US $\$ 1000$ in value toll-free as a personal weight allowance into the Russian Federation. This law generated an entire branch of informal cross-border couriers, the so-called chelnoki, who are often organized into commercial groups that are paid wages to import bulk loads for wholesale traders. Chelnok literally translates as 'weaving shuttle', signifying the traders' repetitive back-and-forth movements across the border. Shuttle trade is not solely confined to the Russia Far East, but is ubiquitous in many border regions of the former Soviet Union. Supplying local markets with consumer goods that range from shoes and apparel to kitchen appliances and electronics, this trade is mostly an effect of the collapsed local small goods industry and the local demand for relatively cheap and affordable consumer goods (Konstantinov 1996, 777). The system of shuttle trade is a highly flexible and adaptable form of small-scale crossborder trade that regularly reacts to changing border regulations, such as changes in the permitted weight.

Accounts from other Chinese border regions suggest a relatively uniform system of shuttle trade along the border, where different degrees of commercialization have created various types of petty cross-border trade. For instance, in the export of Chinese trade goods to Vietnam, local traders are able to purchase directly from Chinese wholesalers and retailers, use mobile Chinese traders, or rely on local transporters and intermediaries, similar to their Russian counterparts (Endres 2014, 618). Another trans-regional characteristic is that the system is able to sustain different types of shuttle traders: solo traders; shuttle traders that hire couriers and accompany them; and whole groups of couriers hired by companies (Han, Nelen, and Kang 2015, 441).

While Russian policy during the mid-20oos tried to curb informal crossborder trade with China, the 2010 Customs Union between Russia, Belarus, and Kazakhstan led to an easing of trading restrictions between those countries. Generally speaking, the shuttle trade in Russia has transformed over the years, from a trade strategy born out of the necessities resulting from the collapse of the Soviet economic system toward a form of advantageous trade (Stammler-Gossman 2011, 234). Tourist motives are also playing 
an increasing role, as traders combine the potential economic advantages of a cross-border sojourn with the amenities of a brief but enjoyable stay in the neighbouring country.

\section{Failure of the Formal: Dis-trust in the State}

Although the cross-border trade has significantly changed over the last 20 years, the underlying social and economic mechanisms remain. Here, I briefly focus on the specifics of the small-scale cross-border trade between Russia and China to explore in more detail the important role of trust as a mechanism and lubricant for informal trade. For instance, strong reliance on middlemen is an important part of trade that not only crosses a national border, but also transgresses significant cultural and linguistic barriers on a regular basis. In many cases, long-term personal relationships with Chinese brokers are essential for the success of Russian small-scale border entrepreneurs. In the absence of a legal framework that is able to enforce contracts, trust plays a paramount role in securing business arrangements outside of state laws. Trust is created through time, by repeated transactions that are successful and beneficial for both sides. Effective social networking is essential, as a shuttle trader explained to me in 2004, when this kind of trade was flourishing in the region:

It is very difficult for an independent shuttle trader to sell merchandise to wholesale dealers in the market if you are unknown. You need connections [sviazi] and acquaintance [znakomstvo] with the right people. If you are unknown in the business, nobody trusts you and wants to deal with you. It is like in every other business in Russia, connections are the most important thing.

Informal economic relations across the border rely heavily on established trust in a business environment where written contracts are almost absent and only social mechanisms are available to enforce arrangements. Anton, a car-part dealer in Vladivostok who relies mainly on shuttle traders to import his merchandise from China, described this to me in 2012:

The whole shuttle trade business is built upon honesty, absolute honesty. The first time you steal, you are kicked out of the market. The Chinese all know each other and the moment you take what is not yours the Chinese are instantly alerted and no one will deal with you after that. You can 
shut your business down. Plus, they tell the customs that you are a shyster and you will start having problems with customs. The whole system is built upon trust and honesty.

The important role of trust in informal economies has been acknowledged by several anthropologists in detailed fieldwork accounts (e.g., Hart 1988; Harriss 2003; Burbidge 2013) after Diego Gambetta's 1988 edited volume Trust: Making and Breaking Cooperative Relations opened the discussion to a range of illuminating interdisciplinary approaches. For the purposes of this article, I follow Luhmann's distinction between personal and impersonal organization to highlight the different operational realms where confidence and trust play crucial, yet contrasting roles (Luhmann 1988, 97). Low levels of systemic trust, i.e. little confidence in formal economic mechanisms, do not exclude - but rather tend to facilitate - alternative, trust-based personal solutions. Personal agency therefore plays a paramount role (Dasgupta 1988; Luhmann 1988). This became particularly prevalent in the post-Soviet Russia of the 1990s, when barter schemes substituted for monetary transactions and required the doveritel'nost' ('trustworthiness') of their links (Ledeneva $2006,132)$. Trust-based, informal economic solutions can therefore be seen as a symptom of the failure of the formal ones. Especially in the cross-border trade with China, the official channels are perceived by small-scale traders as highly corrupt and unpredictable. Cross-border traders have to weigh the unreliability and uncertain costs of official import channels against the practicability of informal solutions:

Chelnoki [shuttlers] exist because there is no other way. Dealing with them is fast and easy. I would like to import goods legally, in their original packages, so that everything is correct. But I do not have this possibility. I would lose money. I do not like all these bags here, I would prefer to have my goods all in neat cardboard boxes, but I have no alternative. If I would know that a truck from China would take a week to get here, I would not even think of using the chelnoki. But I do not know how many days it will take. It could be $5,7,30$, or 40 days. If there are no rules, you have to make up your own. If the government is not able to create the conditions to make a living, we are going to cheat the government. What other option do we have?

This is an often-voiced attitude: if the government is unable to provide a secure and predictable business environment, people are forced to retreat into the informal. The sentiment of trading against the state or 
circumventing legal regulations surfaces repeatedly in the conversations that other researchers have had with shuttle traders along Russia's borders. For instance, Natalia Ryzhova argued, based on her research among shuttle traders in the twin border towns of Blagoveshchensk (Russia) and Heihe (China), that these forms of informal strategies lead to trans-local market consolidations, independent of the state and in effect operating against it (Ryzhova 2008). Anna Stammler-Gossman encountered a similar beat-thesystem' approach in her work along the Russian-Finish border, as one of her informants elegantly expressed: 'Do not violate the law, but know the ways to avoid it' (Stammler-Gossman 2011, 241).

A similar antagonism also surfaces in the local discourse on poaching and illegal wildlife trade with China. The people engaged in poaching wildlife products are mostly local Russians, while the middlemen and buyers are Chinese. The socio-economic profile of the suppliers of wildlife commodities in the Primorye and Amur regions - mostly residents of remote rural areas and suburban residents who do not have a source of steady income - points to the economic predicament of rural areas in the region (Vaisman 2001b, 124). In Primorsky Krai, there are conflicting images of the role the border population play in the trade between China and Russia. One image portrays shuttle traders and poachers as mere unintentional helpers of Chinese middlemen, who exploit the national resources for personal gain. A second image presents poachers as stigmatized predatory exploiters of Russian resources and as the wilful accomplices of foreign entrepreneurs. A third, more apologetic image recognizes the illegal nature of poaching and the depletion of endangered species, but insists on the importance of the economic benefits for the local population: poaching provides a needed and 'secure' cash income in this debilitated economic environment. For many residents of rural areas, poaching simply presents an economic survival strategy. In some Far Eastern and Siberian regions this illegal or semi-legal business involves some 40 to 70 percent of the population (Vaisman 2001b, 124). As a local poacher explained: 'If you find a good root [of ginseng], you might not have to go hunting anymore the whole season. I have to pay 20,000 roubles for the education of my daughter. If I go to the taiga, dig up a root and sell it to the Chinese everything is taken care [of]' (cited in Dronova and Shestakov 2005, 54). A similar situation applies to the population living in the districts of Primorsky Krai along the border with China. Excluded from the economic boom of the late 1990s, which was mainly profitable for urban centres like Vladivostok, a mostly rural population found needed employment in the grey economic sector of the shuttle trade. 


\section{'Thieves in Epaulettes': The Visibility of Distrust}

On a methodological level, the question of visibility arises when researching and documenting the level of trust citizens have in their own state. In the following section I mention several publicized events that had a strong local impact and affected public opinion in the Russian Far East, and which I see as symptomatic of the strained relationship between the Russian state and its Far Eastern regions. These are anecdotal, singular events, yet they reflect a certain zeitgeist that has settled in the region over the last few years.

The first event took place in 2008, when Vladivostok witnessed one of the largest public demonstrations since the dissolution of the Soviet Union. 40,00o people amassed on the streets, holding anti-Putin placards for the first time, to protest the newly introduced customs duties on the import of used Japanese cars. The port city still houses one of the largest open-air used car markets in Russia. Locally known as 'Green Corner' and perched on a series of hilltops above the city, the market operates as a central hub for customers from across the Russian Far East and Siberia. For years, this business represented one of the main staples of Vladivostok and Primorsky Krai, with tens of thousands of people directly and indirectly involved (Kalachinsky 2010, 3). In response to the new taxes, the local anger and resentment spilled over. Not trusting the local police, Moscow had to send

Figure 6 The ‘Green Corner' market for used Japanese cars, Vladivostok

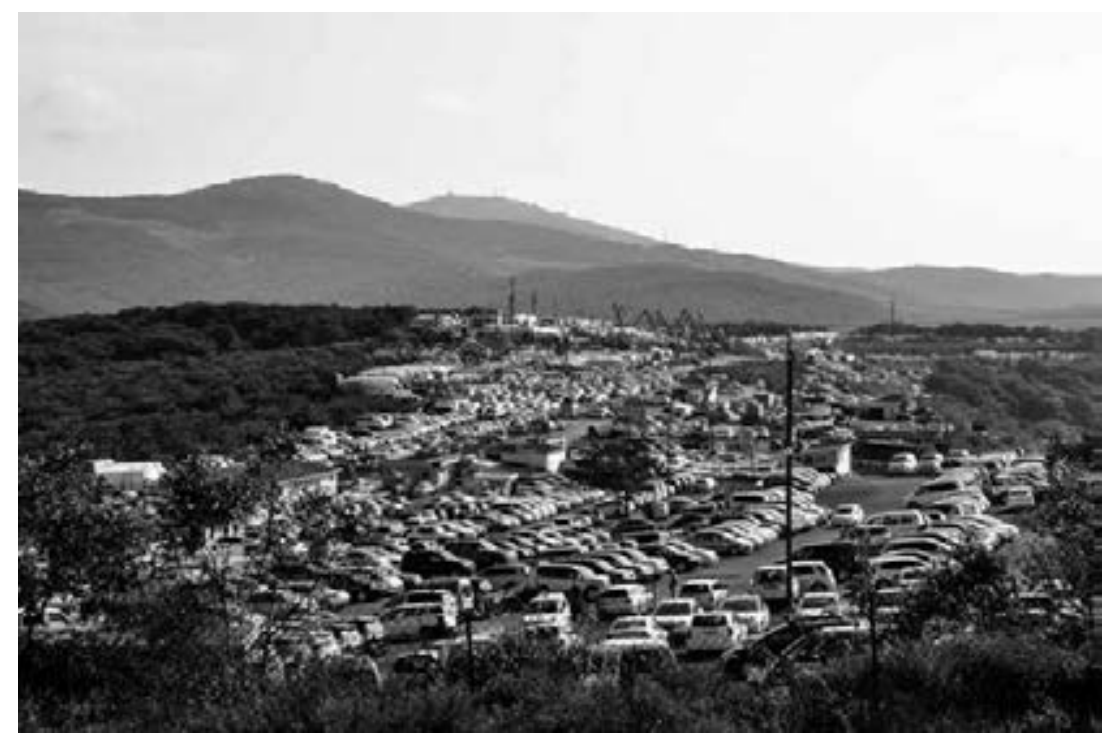


armed OMON (Special Purpose Mobility Unit) forces from the capital to finally defuse the situation. By merely raising the customs tariff on used cars from Japan, the Russian government had dealt a strong blow to a local industry, and this had a strong negative impact on the way people perceived the government.

Another event speaks to the pronounced mistrust of state representatives and local authorities, which is generally strong in Russia and even more in the Russian Far East. In the summer of 2010, a violent conflict erupted in the mountainous forest north of Vladivostok between a group of young men and representatives of the state. Remote police stations were plundered and set on fire, several police officers were wounded and one was killed. According to the local press, the armed group was chiefly motivated by the police brutality they had suffered earlier while under detention for minor infractions. For almost two weeks this gang, locally known as the 'Forest Brothers', launched a form of 'partisan' warfare against the local police, who were again supported by tanks and Special Forces specially sent in from Moscow. Two weeks later the standoff ended with a showdown in Ussurisk, where the gang members had barricaded themselves into an apartment. During the ensuing shootout, most of the members were killed or committed suicide.

This violent episode might have easily faded unnoticed into history, if it were not for the public resonance it created. According to Internet polls, 70-8o percent of the local population was on the side of the so-called 'partisans'. Graffiti appeared overnight at public places in Vladivostok: 'Partisans, your deed is not forgotten'; 'Partisans of Primorye are heroes of the Rus'; 'Glory to the Primorye Partisans! Don't believe the mass media!' Opinion polls conducted by the Levada Center in 45 regions of Russia during the aftermath of these events show the national prevalence of these locally expressed sentiments (Levada Center 2010). When asked, 'Who should the man on the street fear more: our militia or "avengers of the people" like the partisans?' 34 percent responded with 'avengers of the people', 34 percent with 'our militia', and 29 percent did not know. Equally revealing are the answers to the question, 'Do you think that this is an isolated incident and a manifestation of local extremism, or an indicator of an extremely negative attitude to the militia in the country?' Out of the respondents who said that they had heard what had happened, 55 percent answered, 'This is an indicator of an extremely negative attitude to the militia in this country', 35 percent answered, 'This is an isolated incident, a manifestation of local extremism', and 10 percent did not know. Another surprise: most of the armed group members were associated with 
right-wing militias. Fuelled by endemic corruption, xenophobia mutated into fear and hatred of the state. One of my informants cynically commented during that time, 'In any other country murderers of policemen are considered dangerous criminals. Here in Russia they are venerated as partisans.'

Detailed local polls commissioned by Transparency International and that form the basis of its Corruption Perceptions Index (CPI) of nations clearly show how the local population of Vladivostok perceives certain state institutions. For instance, in a 2004 survey 80 percent of respondents believed that all or most officials at all levels of government operating in the Krai were corrupt (MSI 2004, i). Local traffic police and customs offices were the institutions associated with the highest degree of corruption. It is important to note here that this is a perception index; it represents attitudes and viewpoints and not necessarily the real levels of corruption. Nevertheless, a persistent general attitude associates state and civil servants in Russia with high levels of corruption. One of the last opposition figures in Russia, Alexandr Navalny, even created a political slogan out of this ambivalent sentiment for the 2011 parliamentary elections: vory v pogonakh ('Thieves in Epaulettes').

High levels of corruption in the customs office are a publicly perceived fact in the region. The Krai, especially the large international container port of Vostochniy (Nakhodka), is known for the practice of 'grey customs clearance' (Huasheng 2010, 7). This practice appeared in the early 1990s, a time when Russia was in dire need of consumer goods from China. To facilitate a simpler customs procedure, some Chinese traders were allowed to receive clearance for a whole consignment of goods, i.e. several containers, under one customs clearance form. From the perspective of a Chinese cross-border trader utilizing informal export/import channels for commodities destined for Russia, the lowering of tariffs is paramount. There are essentially four different methods that can be used to do this (Zabyelina 2012, 104-105): (1) the 'invoice fraud scheme', where the commodity value is wrongly stated (lowered); (2) the 'kill the weight scheme', where the weight is wrongly declared (lowered); (3) 'disassembling', where commodities are taken apart to lower import costs; and (4) the 'combined goods scheme', where expensive goods are hidden under cheaper ones. The complicit involvement of rentseeking customs officials is a precondition for all of these strategies. One of my conversation partners in Vladivostok, a trader regularly involved in cross-border shipments from China, referred to one smuggling operation that was uncovered in 2000 and which had been protected by high-ranking state officials: 
As part of the 'Three Whales' scandal, wagons and whole trainloads full of stuff moved through our customs in Nakhodka to Cherkisovsky Market in Moscow. This was a big case, but it was closed and nobody was convicted. So, apparently, you can smuggle on this scale without being bothered. You can import 20 containers full of Adidas sneakers, but you are not allowed to import a single bag of them. You know why? Because the people from Moscow do not earn anything from the small-scale smuggling here. Despite a high-profile investigation by the customs inspection, which implicated senior FSB officials, the investigation into the 'Three Whales' was eventually halted; the charges pending were dismissed, and the customs inspection officials who led the investigation were charged with abuse of office.

A few years later, a similar case of large-scale smuggling involving senior FSB (Federal Security Bureau) personnel and local politicians again centred on the Primorye port of Nakhodka. As in the 'Three Whales' case, the actual persons who were tried in court were not the allegedly corrupt officials, but instead the officials who had led the investigation. In this case, the victim was the Far Eastern Customs Directorate Chief, General Ernest Bakhshetsyan, who had been tasked, ironically enough, with strengthening his office's fight against smuggling and corruption and increasing tariff revenues. He was ultimately convicted on charges of abuse of office by a Vladivostok court and sentenced to five years in prison in 2007. Yet up until this time, large-scale, informal imports protected and organized by state agencies were the rule rather than the exception, as my informant continued:

Everything could be imported through Nakhodka before the closure of that channel - everything besides guns and drugs, which were their [FSB's] own business. For US\$ 7,00o per container, no questions [were] asked. The pipeline was closed in 2007 , and now only small holes remain. Back then they were dealing in billions, not millions [of dollars].

Smuggling activities that are protected by officials have an inherent advantage over those that are not protected. Similar to the selective protection through mafia networks, which have features of a positional good (Gambetta 1988, 165), corruption is not equally spread, but rather unevenly divided - a fact that the unprotected know only too well:

After the collapse of the Soviet Union life opened like an accordion, yet somehow it all contracted again. A couple of years ago we still laughed at it, but now it has become unbearable. At every point of my business 
I have to pay bribes, sometimes more hidden, and sometimes just plain cash in an envelope. A couple of years ago everybody talked about the 'yellow peril'. Chinese and other migrant workers were seen as the enemy. Nowadays there is only one enemy: Moscow!

This quotation from the same informant hints at yet another aspect of how trust and perception are interlinked and embedded in the centre-periphery triangle of Moscow, the Russian Far East, and China. Although the region's economy has benefited from the Chinese traders who provide urgently needed food supplies and consumer goods, the cross-border flow of people, goods, and services created security concerns and socio-economic grievances among both the political elites and the local residents (Alekseev 1999, 1). Public and official perceptions of these processes were framed in reference to a new 'yellow peril' (Larin 1995; Vitkovskaya 1999). Despite these negative perceptions, since the mid-200os the anti-Chinese media coverage in Primorsky Krai has sharply dropped. This trend parallels the regional change of political elites. In 2001, Sergey Darkin replaced Yevgeniy Nazdratenko, who had been known for his anti-Chinese bias, as governor. On the regional political level, economic incentives now seem to override xenophobic sentiments, in part due to the recognition of the importance of growing economic and geopolitical ties to China. The notion of a 'yellow peril' is slowly being replaced in official discourse by references to a 'yellow future'. This new discourse re-examines the region's particular economic and geopolitical situation in a more constructive and positive light.

Yet, one recent event signalled a significant reversal in Sino-Russian relations and exemplified how local and international trade are embedded in the overall centre-regional dynamics. In June 2009, the Russian government closed Moscow's largest open-air retail market and confiscated its goods. Cherkizovsky Market, which involved thousands of Chinese traders, had been supplied by Chinese merchandise through the Trans-Siberian rail link from Naklhodka. Its closure was meant to signal a concerned state's interest in ending the established practice of grey customs clearance, but it resulted in significant losses for and exclusion of Chinese businessmen, who saw it as a mere ploy to protect local producers (Huasheng 2010, 7). On the level of Russian centre-periphery relations, it was clearly a sign of Moscow exerting and strengthening its control over the Russian Far East. 


\section{Conclusion: Trust from Below}

Just as the study of corruption provides a lens with which to view the perception and conception of the state (Shore and Haller 2005, 8; Gupta 1995), the relationship between traders, the border, and the state offers insight into how the state is perceived by actors on its periphery. The Russian Far East has been an outlying borderland throughout its history; in this respect, it is similar to other peripheral localities of Russia. Cycles of decentralization and recentralization have shaped the region's relationship between local elites, inhabitants of the borderland, and the state's power centre (Gorenburg 2010; Libmann 2010). Phases of 'state tutelage' characterized by increased material inflow into the region have alternated with periods of 'suspension', when the region was essentially abandoned by the state (Bliakher and Vasileva 2010). After the collapse of the Soviet Union, the Far East was in such a state of suspension, and the consequence was that the informal/illegal economy grew substantially. Bliakher and Vasileva have argued that the Russian Far East has historically functioned as a 'land in reserve' $(2010,84)$ : its status has thus been economically and politically structured by its relationship with Russia's political and economic centre (i.e. Moscow). During the first 20 years of the post-Soviet period, the region was in a state of suspension, when 'interregional space becomes invisible for the state' (ibid., 90). With President Putin's so-called strengthening of the power vertical, Russia has sought to recapture its influence over its eastern borderland. This effort at recentralization has been only partially successful in curtailing the region's burgeoning informal economy.

In this fluid political and economic border landscape, shifts of loyalties are an expected outcome. Similar to the 19th century Italian Mezzogiorno region, one of the birthplaces of the Mafia, eastern Russia is characterized by a low degree of 'systemic trust' (Luhmann 1979) - a fact that has been repeatedly correlated with the prevalent high levels of corruption. For instance, Vladimir Kulygin, the chair of Criminal Law and Criminology at the Khabarovsk State Academy of Economics and Law, cited lack of trust in and alienation from state agencies as one of the root causes of corruption in Russia:

I'll take risk to come up with the following idea. Corruption in Russia is a kind of surrogate for law, a mechanism making up for the lack of social justice. Under the reciprocal alienation of community and state when law enforcement bodies fail to effectively do their job, bribery and corrupting 
officials is sometimes the only way to secure one's lawful rights and not always lawful interests. Therefore, I agree with A. Maiko that 'corruption has taken root in peoples' minds as a natural phenomenon'. (Kulygin 2004)

And yet, mutually accepted and practiced corruption is not the only answer. Alternative anchors become equally important. In an environment of mutually perceived vulnerability, personal trust constitutes a positive opposite (Burbidge 2013, 87). In this light, Tilley's predictive observation of a resurgence of trust networks in modern commerce gains plausibility. Informal economic solutions, based on trust networks, become an alternative to the loyalty ties embedded in state trust. Here, trust from below seems to provide a counterweight for the lack of trust in official structures and mechanisms. The seemingly paradoxical situation - the simultaneous existence of low levels of systemic trust and high levels of interpersonal trust - are thus two sides of the same coin, representing a subtle shift away from loyalty to the state toward networks of interpersonal loyalties.

\section{References}

Arsenyev, V.K., 1914. Kitaytsyv Ussuriyskom Krae [The Chinese in the Ussuri Region]. Khabarovsk: Tipografiya Kantseliarii Priamurskogo General'-Gubernatora. Arsenyev, V.K., 1926. Russen und Chinesen in Ostsibirien. Berlin: August Scherl. Alekseev, M.A., 1999. The 'Yellow Peril' Revisited: The Impact of Chinese Migration in Primorskii Krai. PONARS (Program on New Approaches to Russian Security Policy Memo Series) Memo No. 94.

Bliakher, L.E. and L.A. Vasileva, 2010. The Russian Far East in a State of Suspension: Between the 'Global Economy' and 'State Tutelage'. Russian Politics and Law, 48(1), pp. 80-95.

Burbidge, D., 2013. Trust Creation in the Informal Economy: The Case of Plastic Bag Sellers of Mwanza, Tanzania. African Sociological Review, 17(1), pp. 79-103. Castells, M., 1996. The Rise of The Network Society: The Information Age: Economy, Society and Culture. Oxford: Blackwell.

Dasgupta, P., 1988. Trust as a Commodity. In D. Gambetta (ed.), Trust: Making and Breaking Cooperative Relations. Oxford: Basil Blackwell, pp. 49-71.

Dronova, N. and A. Shestakov, 2005. Promysel kak zhisn': Prirodookhrannye I sotsial'no-ekonomicheskie aspekty pushnogo promysla na dal'nem vostoke $i$ torgovli pushinoiv Rossii [Hunting and trapping as a way of life: Conservation 
and socio-economic aspects offur trapping in the Far East and of the fur trade in Russia]. Moscow: TRAFFIC Europe-Russia.

Endres, K., 2014. Making Law: Small-Scale Trade and Corrupt Exceptions at the Vietnam-China Border. American Anthropologist, 116(3), pp. 611-625.

Filippovskii, E., 2004. Tamozhnaia sgovorilas' s militsiei perekryt' kanaly kontrabandy lesa [Customs cooperate with police to cut off smuggling channels of illegal timber]. Kommersant, 18 September.

Gambetta, D., 1988. Trust: Making and Breaking Cooperative Relations. Oxford: Basil Blackwell.

Gorenburg, D., 2010. Center-Periphery Relations after Ten Years of Centralization. Russian Politics and Law, 48(1), pp. 3-7.

Gupta, A., 1995. Blurred Boundaries: The Discourse of Corruption, the Culture of Politics, and the Imagined State. American Ethnologist 22(2), pp. 375-402.

Han, C.-R., H. Nelen, and Y. Kang, 2015. A Case Study on Shuttle Trade between Korea and China.Journal of Borderlands Studies, 30(3), pp. 437-451.

Harriss, J., 2003. 'Widening the Radius of Trust': Ethnographic Exploration of Trust and Indian Business. Journal of the Royal Anthropological Institute, 9(4), pp. $755^{-773}$.

Hart, K., 1988. Kinship, Contract and Trust: The Economic Organization of Migrants in an African Slum. In D. Gambetta (ed.), Trust: Making and Breaking Cooperative Relations. Oxford: Basil Blackwell, pp. 176-193.

Hiraizumi, H., 2010. Trade of Heilongjiang Province (China) with Russia. IDE Discussion Paper No. 246, Institute of Developing Economies, Chiba, Japan.

Huasheng, Z., 2010. Sino-Russian Relations 2009 to 2010: A Perspective from China. Russian Analytical Digest, 73, pp. 5-8.

Kalachinsky, A., 2010. Putin is Turning Vladivostok into Russia's Pacific Capital. Russian Analytical Digest, 82, pp. 2-9.

Kattoulas, V., 2002. Crime Central. Far Eastern Economic Review, 165, pp. 48-51.

Khisamutdinov, A.A., 1993. The Russian Far East: Historical Essays. Honolulu: A.A. Khisamutdinov.

Konstantinov, Yu, 1996. Patterns of Reinterpretation: Trader-Tourism in the Balkans (Bulgaria) as a Picaresque Metaphorical Enactment of Post-Totalitarianism. American Ethnologist, 23(4), pp. 762-782.

Kulygin, V., 2004. Power and Corruption in Russia: Past and Present. http://www. crime.vl.ru/index.php? $=913$ \& print $=1 \&$ more $=1$.

Landgraf, D., 1989. Amur, Ussuri, Sachalin (1847-1917). Neuried: Hieronymus Verlag. Larin, V., 1995. Yellow Peril Again? The Chinese and the Russian Far East. In S. Kotkin and D. Wolff(eds.), Rediscovering Russia in Asia: Siberia and the Russian Far East. London: M.E. Sharpe, pp. 290-301. 
Ledeneva, A.V., 2006. How Russia Really Works: The Informal Practices That Shaped Post-Soviet Politics and Business. Ithaca: Cornell University Press.

Levada Center, 2010. Russian Opinions on Vigilante Killings of Members of the Militia in Primorye, 18-22 June, http://www.levada.ru/en/

Libmann, A., 2010. Cycles of Decentralization in the Post-Soviet Space. Russian Politics and Law, 48(1), pp. 8-12.

Luhmann, N., 1979. Trust and Power: Two Works. New York: John Wiley.

Luhmann, N., 1988. Familiarity, Confidence, Trust: Problems and Alternatives. In D. Gambetta (ed.), Trust: Making and Breaking Cooperative Relations. Oxford: Basil Blackwell, pp. 94-107.

Malone, T.W. and R.J. Laubacher, 1998. The Dawn of the E-Lance Economy. Harvard Business Review, September.

MSI (Management Systems International), 2004. Public Opinion of Corruption in Vladivostok: Results of Public Opinion Survey, May 2004. Washington, DC: MSI.

Rifkin, J., 2000. The Age of Access: The New Culture of Hypercapitalism. New York: Penguin.

Ryzhova, N., 2008. Informal Economy of Translocations: The Case of the Twin City of Blagoveshensk-Heihe. Inner Asia, 10, pp. 323-351.

Shore, C. and D. Haller, 2005. Introduction - Sharp Practice: Anthropology and the Study of Corruption. In D. Haller and C. Shore (eds.), Corruption:Anthropological Perspectives. London: Pluto Press, pp. 1-28.

Stammler-Gossman, A., 2011. 'Winter-Tyres-for-a-Flower-Bed': Shuttle Trade on the Finish-Russian Border. In B. Bruns and J. Miggelbrink (eds.), Subverting Borders: Doing Research on Smuggling and Small-Scale Trade. Wiesbaden: VS Verlag, pp. 233-256.

Tilly, C., 2001. Welcome to the Seventeenth Century. In P. DiMaggio (ed.), The Twenty-First-Century Firm. Princeton: Princeton University Press, pp. 200-209. Vaisman, A., 2001a. Trawling in the Mist: Industrial Fisheries in the Russian Part of the Bering Sea. TRAFFIC species in danger report, November.

Vaisman, A., 20o1b. Illegal trade in wild animals and plants between the Russian Far East and Northeast China. In E. Shvarts, E. Simonov, and L. Progunova (eds.), Environmental Risks to Sino-Russian Transboundary Cooperation: From brown plants to a green strategy. Moscow: WWF, pp.120-126.

Van Dijk, J., 1999. The Network Society: Social Aspects of New Media. London: Sage. Vitkovskaya, G. 1999. Vynuzhdennaia Migratsiia i Migrantofobiia v Rossii (Forced migration and migrantophobia in Russia). In G. Vitkovskaya, and A. Malashenko (eds.), Neterpimost'v Rossii: starye i novye fobii (Intolerance in Russia: Old and new phobias). Moscow: Moskovskii Tsentr Karnegi. 
Williams, B., 2003. The Criminalization of Russo-Japanese Border Trade: Causes and Consequences. Europe-Asia Studies, 55(5), pp. 711-728.

Zabyelina, Y., 2012. Costs and Benefits of Informal Economy: Shuttle Trade and Crime at Cherkizovsky Market. Global Crime, 13(2), pp. 95-108. 


\title{
Can Kinship Come to the Rescue?
}

\author{
Trust and Cooperation across the Border between China \\ and Mongolia ${ }^{1}$
}

Nasan Bayar

Humphrey, Caroline (ed.), Trust and Mistrust in the Economies of the China-Russia Borderlands. Amsterdam: Amsterdam University Press, 2018

DOI: $10.5117 / 9789089649829 /$ BAYA

\begin{abstract}
Inner Mongols find themselves in a special situation of relatedness to both China and Mongolia, and thus can play a 'bridge' role in the two countries' economic transactions and other relations. Sharing a common historical, ethnic, and cultural heritage with Mongolians and being citizens of China, are they in fact in a (dis)advantageous position for making links between the two realms? This chapter, based on fieldwork conducted in a Chinese border town, discusses the case of a network that brings together Inner Mongol intermediary agents and Mongolian truckers in an unusually successful alliance. Kinship is one of the key resources called upon. The focus of the chapter is on exactly how the relevant actors create trust that can provide the basis for them to cooperate and ensure mutual benefits.
\end{abstract}

Keywords: kinship, trust, cooperation, Mongolia, China, coal, truckers

\section{Introduction: How do you become relatives?}

When the Chinese president Xi Jinping made his first official state visit to Mongolia in August 2014, his address to the Mongolian parliament compared his visit to Mongolia with visiting a relative (zou qinqi de fangwen), and stated that the relationship between China and Mongolia had arrived

1 I am pleased to thank Caroline Humphrey for her enlightening suggestions and amendments to my writing of this article. I am also grateful to Uradyn E. Bulag and Tom White for their helpful comments and editing. I thank the National Social Sciences Fund of China for a research grant (16AMZoo3) which enabled me to complete this research. 
at the best period of its development in history. He also published an article in Mongolian newspapers ${ }^{2}$, which emphasized that the more frequently relatives visit one another the closer the relationship becomes (qinqi yue zouyue jin); the longer the friendship, the stronger the feelings that develop will be (pengyou yue jiao yue shen).

Why and how does China claim that Mongolia is her 'relative'? The term 'relative' can evoke various imaginaries concerning the relationship of the two countries. At one level, it may refer to historical relations between the two countries - but this historical relatedness also raises many questions. Was the Mongol-dominated Yuan Dynasty a normal dynasty in the history of China, or was it a branch of the Mongol Empire? Between the 17th and early 20 th centuries, was Mongolia ruled by an independent Manchu regime, or was it ruled as part of a Chinese dynasty?

At a different level, one can connect the term 'relative' with a specific ethnic group in China's national configuration that shares some kinds of kinship with the Mongolians of present-day Mongolia. Indeed, we cannot avoid Inner Mongolia as a region and the Mongols living there (colloquially called Inner Mongols) as a people when we talk about the connections between China and Mongolia. Inner Mongols are related to the two countries in different ways: they are Chinese in terms of citizenship and Mongolian in terms of ethnicity. Therefore, one could say that it is the Inner Mongols that form the basis for considering the two countries to be 'relatives'. During an Inner Mongolian media interview a couple years ago, a Mongolian diplomat said that the Inner Mongols, as a people who share a cultural and linguistic heritage with the Mongolians of Mongolia, are a positive force that could play the role of a bridge in the economic and other relationships between Mongolia and China. This is indeed what Uradyn Bulag called for as early as 1998 in his book Nationalism and Hybridity in Mongolia.

Recently, the two countries have decided to align their infrastructural initiatives, China's Belt and Road (otherwise known as the 'New Silk Road') and Mongolia's Steppe Road, in order to improve their cooperation in trade, investment, and other fields. However, international policy declarations about collaboration do not necessarily translate into equivalent relations on the ground. Even in the Socialist era, they could be undermined by undeclared national agendas (Mihailescu, Iliev, and Naumovic 2008) or by hierarchical relations between brotherly entities (Humphrey 2004); today,

2 Xi Jinping published a signed article entitled "Galloping Toward a Better Tomorrow for China-Mongolia Relations" in Udriin Sonin, Unuudur, Zuunii Medee and the UB Post and on the Mongolia Web News website on August 21, 2014. 
when greater initiative by non-state private enterprises is allowed, the translation of government proposals into actual cooperation is all the more uncertain. The Inner Mongols may be represented as 'relatives', but what role do they actually play in the connections between the two countries? Can each state trust them to participate when they seek to activate the cooperation between the two strategic initiatives? Analysing this situation presents us with 'the task of situating the international and the local in relation to one another without either assuming an opposition between levels or collapsing the two into one, or ignoring the political field in which they generate meaning' (Borneman 1998, 9). As this chapter will argue, beneath the overarching political-diplomatic idiom of 'relatives', microscale networks of actual relations, based largely on kinship, can eliminate much of the misdeeds and lack of trust that are otherwise likely to occur between citizens belonging to different states and ethnicities - although, as I shall describe, the ability to form such networks in a cross-border political field is dependent on the delicate concatenation of particular linguistic and cultural circumstances.

Francis Fukuyama points out that trust, as a foundation of social virtue in capitalist environments, plays a significant role in economic cooperation (1995). He argues $(1995,27)$ that in any given society it is spontaneous sociability, 'the capacity to form new associations and to cooperate within the terms of the reference they establish', that extends trusting relations into economic activity. In Asian countries like Japan and Western countries such as the USA or Germany, this trustfulness reduces the cost of economic operations. Such spontaneous sociability can be based on various foundations; it could indeed emerge from a pre-modern cultural heritage - the Japanese spirit of Samurai, for instance - which has transformed to become a basis of trust in modern cooperation in the economic field $(1995,11)$.

According to Hardin's rather different approach (1992), trusting somebody requires knowledge of the one who is trusted, based on experience. Although they share a long history, Inner Mongols and Mongolians have been separated into two polities since the early zoth century. There was very little contact between them during the decades when Inner Mongolia, as part of China, was cut off from Soviet-dominated Mongolia. However, since the early 199os the Mongols from the two sides of the border have had opportunities to interact face to face, thanks to the Chinese policy of 'Opening up and Reform' and the Mongolian shift to a market economy and democratic system. When they meet each other in international trade and other occasions, do they feel like relatives or like some kind of familiar stranger? In the context of the high-level cooperation initiated by the two 
governments, can ordinary actors establish trusting relations based on the 'spontaneous sociability' that might emerge from a common language, culture, or other heritage?

Based on my fieldwork conducted in recent years at the Ganchmod port of entry, an important border crossing through which Inner Mongolia imports coal from the Tavan Tolgoi mine in Mongolia, I would like to discuss how Inner Mongols create links across the border between China and Mongolia.

\section{The Inner Mongolian border town of Ganchmod: The venue of our story}

Trade, more precisely the trade of mineral resources, has become a major component of the relationships between China and Mongolia. Mongolia's coal and other mineral resources are exported by truck to China, mostly through inland border-ports. To import these much-needed goods, China has accelerated the construction of these ports along its border with Mongolia and invested in the development of the mining industry in Mongolia. In recent decades, it has opened eight main ports ${ }^{3}$ of entry in Inner Mongolia along the border with Mongolia. Ganchmod port is located at the northernmost part of the Urad Middle Banner, Bayannuur Municipality, Inner Mongolia ( $\left.\mathrm{N}^{\circ} 2^{\circ} 24^{\prime} 6^{\prime \prime}, \mathrm{E} 107^{\circ} 34^{\prime} 1^{\prime \prime}\right)$. The corresponding port on the Mongolian side is Gashuun Suhait, which is 12.8 kilometres away.

Ganchmod, previously a border guard station for regular meetings with Mongolian counterparts, was identified as a temporary entry point for imports by the Chinese government in 1990. Two years later, in accordance with an intergovernmental agreement, Ganchmod was promoted to the status of an 'A' class seasonal port, permitted to open for a certain number of days each season. In 2004, the two countries agreed to open Gashuun Sukhait and Ganchmod as regular corresponding ports, and Ganchmod began operations with the permission of the Chinese State Council three years later. It has expanded greatly in the last decade with the exploration and development of the Tavan Tolgoi coalmine in Mongolia's Ömnögovi province. Reports indicate that the trade of coal through the port has been growing dramatically, from receiving only 20 trucks of coal in 2004

3 The other seven ports from west to east are Tseke, Mandal, Ereen, Juunhadavch, Arshaan, Ovdeg, and Arhashaat, and the respective corresponding Mongolian ports are Shivee Hureen, Hangi, Zamiin Uud, Bichigt, Sumber, Bayanhoshuu, and Havirga. 
Figure 7 Trucks lining up to cross the border to transport coal from Mongolia to China, 2013

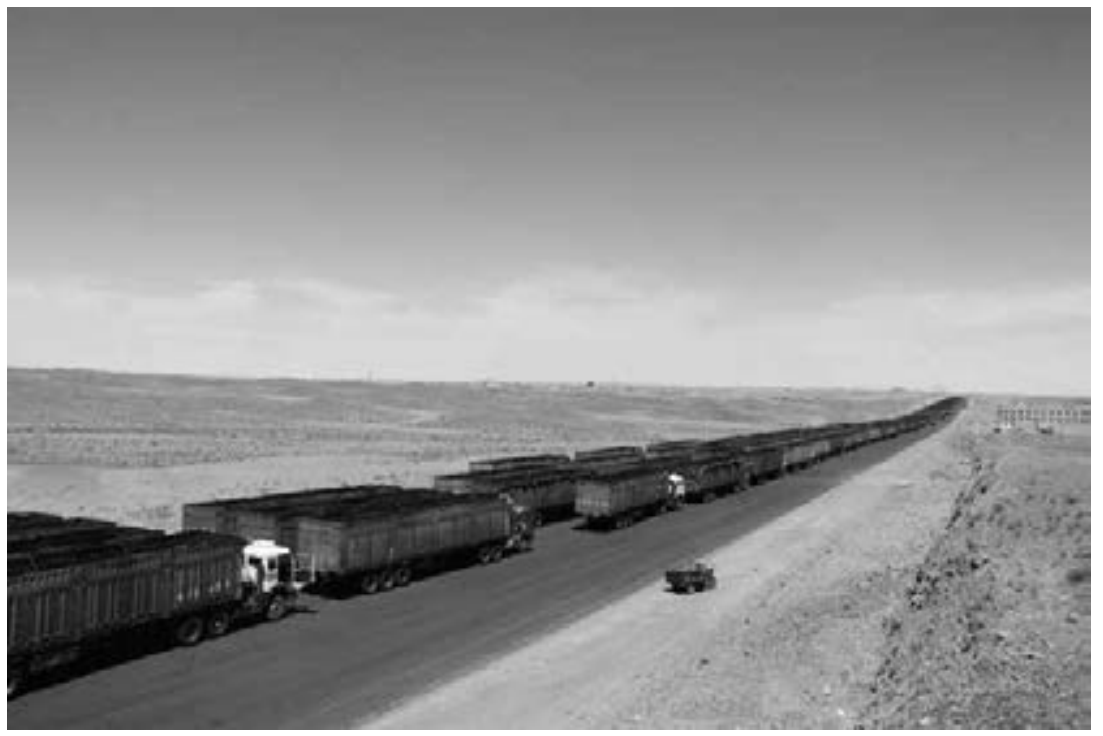

Photo: Nasan Bayar

to 8,500 trucks in 2014; during 2011 and 2012, the weight of the coal annually imported through Ganchmod reached over 40,000,000 tons. According to statistics from the Inner Mongolia Exchange Center for Coal, in a single month (March 2015) over 100,000,000 tons of coal were imported through the port. ${ }^{4}$

There have, however, been problems with this massive import of coal (Figure 7). Direct transportation from Tavan Tolgoi, located 257 kilometres from Ganchmod, has been monopolized by Chinese companies. But there is also a small station inside Mongolia called Tsagaanhad, which is located 25 kilometres away from Ganchmod. This is a station where coal from Tavan Tolgoi can be stored before being transferred to Ganchmod. This means that there are two ways to transport Tavan Tolgoi coal to China: directly from the mine, or from Tsagaanhad. The long-distance conveying of coal is more cost-effective, at 110-128 RMB per tonne, while the short-distance is cheaper, at $45^{-} 5^{\circ} \mathrm{RMB}$ per tonne.

4 This report was published on Inner Mongolia Market of Coal website (neimenggu meitan jiaoyi shichang) on December 22, 2015. 


\section{Buyan and the need for an intermediary agency}

Many Inner Mongols, especially college graduates, have sought career opportunities in the emerging and expanding border towns since the 199os. Buyan, the main figure in our story, is one of them. Buyan was born in 1986 in Bayan-Onder Sum of the Ar-Horchin Banner, Ulaanhad (Chifeng) municipality in eastern Inner Mongolia. His father told him that their original home was Darhan Banner, and that their ancestors emigrated from there to Jaruud Banner in eastern Inner Mongolia in the 1920s, when many local herders lost their pastureland due to the banner's land, like that of many other banners in Inner Mongolia, being taken over for cultivation. Later, the family, led by his grandfather, migrated from Jaruud to Bayan-Onder Sum in search of a better standard of living. Now Buyan identifies strongly with this Sum and the Ar-Horchin people.

Buyan has three siblings: an elder sister, a younger brother, and a younger sister. His two sisters are married and live separately from his household. His household has the use rights of 180 hectares $^{5}$ of pastureland where they graze over 300 sheep, while also growing fodder and vegetables for their own consumption on 1.3 hectares of cultivated land. The household enjoyed higher than average prosperity before Buyan got involved in business at the border port. After graduating with a degree in ethnology from Inner Mongolia University in 2009, Buyan went to Ganchmod port for a job, after an older man from his Banner who worked there told him that there were opportunities for young people. Although not a high achiever in ethnology, Buyan learned a lot about how to communicate with others after getting to Ganchmod, where he also developed the ambition to have career in business. He was first hired as a trucker in 2011, by an international trade company that organized the transport of coal from Tavan Tolgai to Ganchmod. At the time, coal hauling from Mongolia to China was conducted almost entirely by Chinese firms. The company that hired him later provided the opportunity for him and the other drivers to purchase a truck in instalments. In 2011, the Mongolian government asked these Chinese companies to hire some Mongolian drivers. It also required that the Chinese citizen truckers transporting coal from Tavan Tolgoi acquire work visas; tourist visas were no longer acceptable for work in Mongolia. Consequently, the Chinese truckers working for transportation companies had to apply for visas, but they were very difficult to come by. Mongolian work visas are classified by various periods (one month, three months, six 
months, etc.), and a work visa costs over 20,00o RMB, including 'gifts' to key personnel in Mongolia. This new situation forced Chinese transportation companies to hire truckers from Mongolia.

When China accepted these proposals, a question emerged: how could the Chinese companies and Mongolian drivers trust each other? It was reported that some Mongolian drivers had disappeared after selling tyres stolen from Chinese trucks in Mongolia, and that some Chinese companies had delayed the payment of salaries to Mongolian drivers. This tension and even crisis of trust between Chinese transportation companies and Mongolian drivers demanded a middleman who could play the role of a guarantor to ensure smooth cooperation in their transportation of coal from Mongolia to China.

\section{Inner Mongols as brokers between Chinese and Mongolians}

When Chinese companies started to hire Mongolians as truckers, the Inner Mongols, and Han Chinese as well, stood to lose the chance of getting jobs as drivers for these companies. But Buyan and other Inner Mongols soon realized that they could actually do a different kind of work as brokers between the Mongolian drivers and Chinese companies. Virtually none of the Mongolian drivers had any knowledge of Chinese language or business, and the same was true of the Chinese companies in terms of their knowledge of Mongolian language and Mongolia. In addition, there were some practical reasons for the two sides to work together through a broker.

At the very early stage, some incidents occurred. Some Mongolian drivers never came back to the Chinese border port after driving trucks from the Chinese side to the Mongolian coalmine. This was caused by the failure of the Chinese companies to pay salaries on time to the drivers: the latter sold tyres and other truck components as compensation. The major tasks for the brokers were therefore to guarantee the timely payment of Mongolian drivers' salaries, and to guarantee that Mongolian truckers would not damage trucks that belonged to the Chinese companies. By 2014, there were more than 100 intermediary agencies in the port - all were managed by Inner Mongols. Today (2015), while many of these firms have problems managing their business, some are quite successful; Buyan's agency is one of them.

Buyan founded his intermediary agency in 2012. First, he had to find a reliable Mongolian trucker. He met a guy called Mönghe who he felt was a trustworthy person. Buyan then hired Mönghe as the bagiin darga ('leader') of his trucking team, paying him a regular salary of $4,000 \mathrm{RMB}$ per month. 
Mönghe also received $20 \mathrm{RMB}$ from each trucker every month. There were 29 truckers in the team in total. Buyan made an oral agreement with Mönghe that he would protect Mönghe's interests in China, while Mönghe promised to find reliable truckers for him. The primary reason for Buyan's choice of Mönghe as his partner was simply Buyan's personal impression of Mönghe. Buyan thinks that a person's character can be assessed through informal communication, by talking together or chewing the fat over dinner. Mönghe had impressed to him as an honest person in this way.

Mönghe employed three people under his own guarantee. This meant that if any of the three created a problem during their trucking in Mongolian territory, such as damaging their vehicle, Mönghe would have to pay the cost. He recruited Dorji (his brother-in-law), Ot-hoo (his younger brother), and Bataa (Ot-hoo's brother-in-law). Next, Dorji enlisted three people with his own guarantee: Dorji's father-in-law, his wife's brother-in-law, and his wife's baziin hurgen ah ('brother-in-law's brother-in-law'). With his own guarantee, Ot-hoo introduced his fellow-townsmen Huyag, Ganbaa, Zayaa, and Baasanjav from Zavhan province. Bataa guaranteed two kinds of people: first, his relatives by blood or marriage, including his half-brother Togtoh and his younger sister's husband; and second, his anda ('bloodbrothers'), three ethnic Kazaks, Zaki, Hadan, and Baska, who had become his blood-brothers through a ritual in which they drank the mixed blood of their thumbs when they worked in the same company in Ulaanbaatar. ${ }^{6}$

6 Anda, a term to refer to a ritualized 'brotherhood' between male equals, is well known from Mongolian historical documents from the 13 th century onwards. Until recently, it was a valued relationship among many Mongol-speaking peoples. However, it is rarely used in this sense in modern Mongolian. One can see it applied in the original meaning in only a few encounters, like Bataa's relationship with the three ethnic Kazaks who became blood-brothers through the blood-mixing ritual. The word anda, however, is now more widely employed, both in Mongolia and Inner Mongolia, as a term simply to denote close relations among men. In Mongolia, a man can use anda toward friends with whom he has maintained trusting relations over a long period; angiin anda ('classmate brother') or daichin anda ('army brother'), for example, are common terms of address among friends who were at school together or comrades-in-arms many years ago. Nowadays in Ulaanbaatar it is also quite common for male teenagers to call one another anda. The term is applied less in everyday conversation among the Mongols in Inner Mongolia. A well-known pop group from Inner Mongolia has named their band Anda (Anda Hamtlag in Mongolian). Naras, the lead singer of the group, explained to me why they chose this name by saying that some of the band members had been together since kindergarten, and others since their teenage years studying music at the same school in Hohhot. When they founded the band in the late 1990s they were around 20 years old. They hoped from the very beginning that they would not only play music but also be setgelee medeltsesen naiz ('feeling-linked intimate friends') forever. Since then, the nine members of the band have been together for some 20 years. Inner Mongols use the combined term ah duu ('older and younger siblings') as a broader idea 
Thus, almost all of the people working in the firm are relatives in one sense or another. Buyan calls the men older him $A h$ ('older brother'), and is called $A h$ by the younger ones. Buyan understands that kinship works well as a guarantee mechanism among the truckers. It is, however, a two-way relation; so while he expected his Mongolian team to be trustworthy (for him), he organized matters so that they could also trust him. Thus, he tried to provide a better logistical service for his truckers while also setting some strict rules for them to follow in their work. He arranged an inexpensive dormitory for them (at a monthly rate of $1,000 \mathrm{RMB}$ per person), which had a kitchen that provided meals at a monthly cost of 1,00o RMB per person. He asked his truckers not to drink alcohol during work time. Although this rule was not easily enforced at the beginning, his truckers gradually accepted and followed it. On top of the guarantees mentioned earlier, he also required each driver to give him 2,00o RMB as a cash deposit against any damage that might occur to their truck. Further, he insisted that the Chinese companies hiring Mongolian truckers buy insurance for their drivers in order to minimize his own potential risks.

Buyan found that personal relations were very important for running his agency. The private affairs of the truckers should be their own business in principle, but Buyan has gradually become involved in some of their personal affairs. Many of the Mongolian truckers, for example, did not know how to manage their salaries, which on average came to over 10,000 RMB per person monthly; as soon as their wages were paid, they would spend all of it on drinking or other leisure activities without any longer-term plan. Buyan helped them save money by sending a portion of their salaries directly to their families' bank accounts in Mongolia, or by putting part of their salaries into his own account so that it could be taken out for their families when they went back home. These measures were welcomed by the truckers - and especially by their wives. Some admitted that they really could not manage such savings by themselves. Some truckers' wives invited him over phone to visit their families in Ulaanbaatar any time he wanted. Buyan also helped his truckers by providing them with instruction in basic spoken Chinese and information about Chinese society and customs. He also arranged introductions to hospitals in Hohhot for their families and relatives, to help them get better treatment. If truckers' wives came to Ganchmod for a visit, he would organize places for them to stay. These investments in the 
team's personal affairs have brought a positive effect on the business of his agency, since the truckers came to trust him and work with him efficiently.

When I asked Buyan about the key reason for the success of his agency, he credited specific compatibilities of language and culture. He said that there are a lot of Inner Mongols from Tongliao municipality in Ganchmod speaking the Horchin Mongolian dialect, but that those people could not communicate well with the Outer Mongolian truckers due to differences between the Horchin and the Halh dialects. He emphasized the advantage of being an Ar-Horchin, because the latter can communicate with Halh Mongolians and also understand the traditional culture well, which is so necessary for interacting with Mongolians. Ar-Horchin people, as he pointed out, have kept their nomadic ways of life in some areas of their Banner, whereas the Horchin Mongols have completely settled down, meaning they have lost much of the traditional culture. Other Inner Mongols from the western parts of Inner Mongolia are not good at running businesses even though they speak a similar dialect to Halh (only one agency run by a local Urad Mongol is successful, according to Buyan). We can see from this that, while all Inner Mongols are potential mediators in the business between China and Mongolia, not all of them are equally well placed to do this effectively.

Even for Buyan, however, the situation was not easy to handle. Though his agency managed the intermediary business carefully, it still occasionally encountered incidents regarding truckers from Mongolia. One of his drivers unintentionally damaged a car belonging to the Customs Service, and Buyan and the Chinese company that owned the truck had to pay a huge sum $(220,000 \mathrm{RMB})$ in damages. Part of this sum $(170,000 \mathrm{RMB})$ was covered by insurance, but the remaining cost had to be shared equally by Buyan's agency, the company, and the trucker involved in the case. In fact, Buyan could never trust the drivers one hundred percent. Buyan told me that once he had established good relations with the Mongolian truckers he found they were trustworthy and kind-hearted guys that he could work with. 'As long as you treat Mongolians nicely, they would do the same to you,' he said. However, he also mentioned during a conversation with me that he normally would not allow all of the people who guaranteed one another to drive back to Mongolia on the same day, just in case they disappeared with their trucks.

Still, in comparison with the other (over 100) intermediary firms in Ganchmod, which altogether employ around 1,00o Mongolian truckers, 7 Buyan thought his own agency was one of the best and most successful.

7 There are more than twice as many Mongolian drivers as Chinese, of whom only around 400 are employed in the coal transport business. 
Some of the other mediator agencies treat their truckers poorly, beating them, for example, when they make mistakes; and some are not able to push the truck-owning companies to pay the drivers' salaries on time. Because of his success, Buyan has been able to take a step up the economic ladder: he now owns six trucks himself, from which was able to make an income of 400,000 RMB in 2013 alone.

\section{Conclusion: Inner Mongols as a 'relative' for the cooperation between China and Mongolia}

China and Mongolia have been trying to find a common ground by linking their 'Belt and Road' and 'Steppe Road' projects at the governmental level, as laid out by the presidents (Mongolian: tolgoi, 'heads') of the two states in recent years. This is a basic framework for cooperation that needs to be activated through more practical connectivity between them, including infrastructural hardware like railways (see Figure 8), roads, or tunnels, as well as cultural and social interaction between the two peoples. In other words, the cooperation between the two countries not only relies on good

\section{Figure 8 Buyan standing reflectively by an unused railway, 2013}

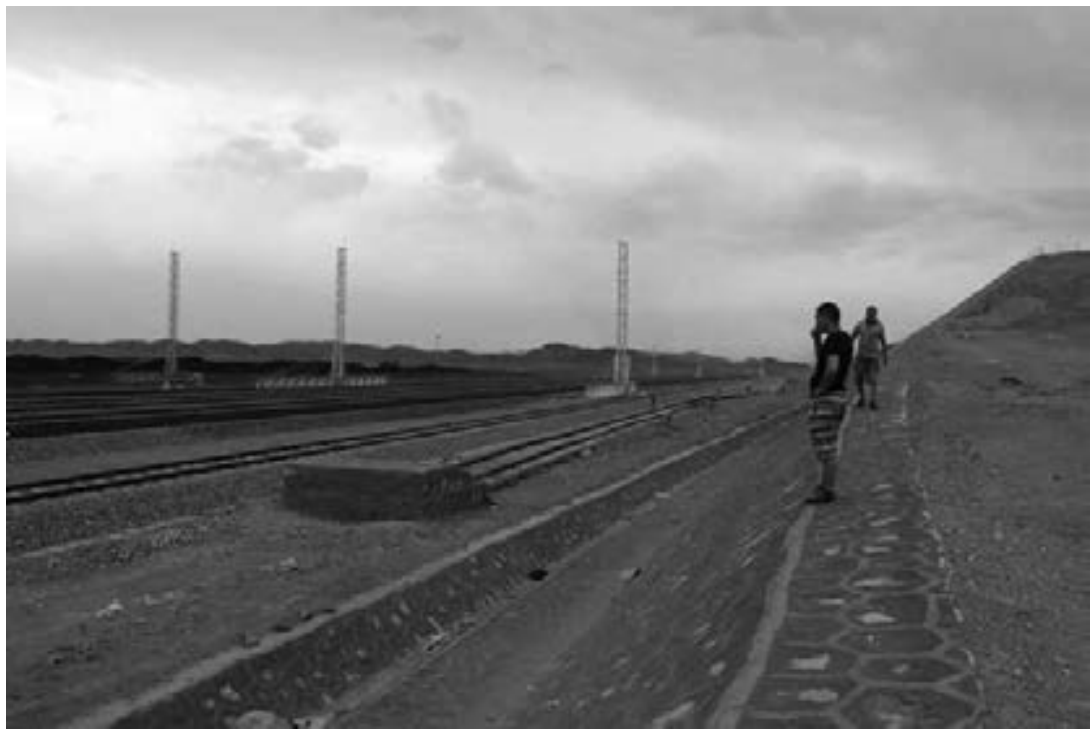

Photo: Oyun 
agreements made by the heads of the governments, but also needs understanding, communication, and work between real people.

The story presented above shows that a group of mediator businesses run by Inner Mongols have been working effectively to build bridges between the two sides, deploying the Mongol language (indeed, a specific dialect), ethnic-cultural backgrounds, and kinship relations as social resources. This has ensured that the two sides can work together without loss or worrying about each other. The core foundation for their cooperation is still their common interest in earning benefits from the trade of coal between Mongolia and China.

And yet this cooperation, based on a network that over time constructs some kind of trust and joint surety, cannot easily be identified with the 'spontaneous sociability' described by Fukuyama. The network relies on previous relationships, and is itself always in the process of formation. Time and care is needed to consolidate such a network in a form that might be able to manage the large-scale economic organizations required for cooperation between two countries. Ancient Mongolian social traditions of creating relations between non-kin individuals, such as anda, a type of blood brotherhood formed between non-kin to cement a political alliance (Atwood 2004, 13), have not functioned as a major factor in the formation of the network in general, although as we have seen anda is seen in some parts of the network.

According to Giddens (1990) and Fukuyama (1995), the trust and spontaneous sociability that function as the base for economic cooperation in modern society are not developed from family or kin groups, but from the sphere of 'civil society' that exists beyond the family. If this is true, then clearly the cultural and social base for setting up networks of this kind between Inner Mongols and Mongolians is fragile and immature in respect to establishing sustainable support for international cooperation.

In addition, we should acknowledge that there have been some negative cases of distrust and even fraudulent conduct between Mongolians and Inner Mongols in recent decades. ${ }^{8}$ Furthermore, the elaborate creation of guarantees shown in this chapter indicates that trust in kin is limited to close relatives and requires special oversight if it is to be extended further into a network. Still, although it is too early to say whether trusting

8 Such negative cases have been reported from Ereen and Beijing, where Mongols came for business or hospitalization with Inner Mongols serving as go-betweens or interpreters. Since some Inner Mongols cheated Mongolians for more benefits, there is a saying among some Mongolians that it is better to ask for help from the tsever hujaa ('real Chinese') than from Inner Mongols. 
relationships and collaboration among ordinary people will have a positive effect on the two countries' cooperation in large economic affairs, this kind of nongovernmental network should not be neglected when considering broader cooperation between the two countries in the future, i.e., not only in the economy, but also in other areas such as cultural exchanges.

Nevertheless, considering the question more broadly and internationally, the Inner Mongols' relatedness to both sides also has the potential possibility of bringing about a blurring of national boundaries: in other words, a potentially destabilizing infiltration from one side to the other. This is important because the two nations, Mongolia and China, are not equal in terms of political and economic power. As John Borneman notes with regard to West and East Germans, particular cultures are both constitutive of, and subversive of, international order $(1998,2)$. Over the course of increased integration through economic and kinship ties facilitated by the Inner Mongols who serve as go-betweens, the wellbeing of independent Mongolia, in terms of both its national sovereignty and its economy, could be at risk. In this sense, Mongolia is indeed the touchstone of the peaceful rise of China (Lin 2014).

\section{References}

Atwood, Christopher P., 2004. Encyclopedia of Mongolia and the Mongol Empire. New York: Fact on Files, Inc.

Borneman, John, 1998. Subversions of International Order: Studies in the Political Anthropology of Culture. New York: SUNY Press.

Bulag, Uradyn E., 1998. Nationalism and Hybridity in Mongolia. Oxford: Clarendon Press.

Fukuyama, Francis, 1995. Trust: The Social Virtues and the Creation of Prosperity. Free Press.

Giddens, Anthony, 1990. The Consequences of Modernity. Cambridge: Polity Press. Hardin, Russel, 1992. The Street-Level Epistemology of Trust. Analyse \& Kritik, 14, pp. 152-176.

Humphrey, Caroline, 2004. Cosmopolitanism and Kozmopolitism in the political life of Soviet citizens. Focaal, 44, pp. 138-152.

Lin Zhengxiu (林正修), 2014. Menggu shi zhongguo heping jueqi de shijinshi [Mongolia is the touchstone to the peaceful rising of China]. Chinese Website of Financial Times, September 2. http://www.ftchinese.com/.

Mihailescu, Vintila, Ilia Iliev, and Slobodan Naumovic (eds.), 2008. Studying People in the People's Democracies II. Berlin: Lit Verlag. 



\title{
Betrayed by Trust
}

\author{
Inter-Korean Relations across Northeast Asian Borders \\ Hyun-Gwi Park
}

Humphrey, Caroline (ed.), Trust and Mistrust in the Economies of the China-Russia Borderlands. Amsterdam: Amsterdam University Press, 2018

DOI: $10.5117 / 9789089649829 /$ PARK

\begin{abstract}
The existence of inter-Korean transactions across the Sino-Russian border is little known. This chapter describes the use of kinship categories to build initial trust between Koreans living in China and Russian Koreans in the Russian Far East, which after a long period of closure and separation became possible when the border re-opened in the early 199os. Based on ethnographic research, I argue that these kinship categories were insufficient: the last decade has seen the re-creation of a boundary between Russian and Chinese Koreans following the breakdown of the equilibrium between trust and economic interest they had established for their symbiotic cooperation. The boundary between the two groups developed when calculative economic reason in the form of betrayal and deception become prevalent in inter-personal relationships. This shift is related to the recent collapse of the local border economy due to state interference and the consequent loss of hope in a profitable joint future.
\end{abstract}

Keywords: kinship, trust and treason, Chinese Koreans, Russian Koreans, Russian Far East

On my way to Mudanjiang, Heilongjiang Province, China in 2012, I happened to stay at a guesthouse in Harbin run by a South Korean man, who I shall call Mr. Bae. The purpose of my trip to northeast China was to discover the views of the people on the Chinese side concerning the Sino-phobia or antiChinese sentiments found in the Russian Far East (hereafter RFE) across the border. There is considerable research on the causes of Sino-phobia inside Russian and Mongolia (Alexseev 2001 and 2006; Dyatlov 2000 and 2012; Billé 2015), but little is known about the stance of Chinese people towards 
these seemingly racist attitudes taken by people living in neighbouring countries. And my particular concern in this paper is the Koreans, who have a complex history of migration to both China and Russia: Where do they stand amid these ethnic sentiments? During a conversation in the evening, when I talked about Sino-phobia in Russia with the owner of the guesthouse, he said straight out: 'They [the Chinese] deserve it, because they are so greedy and like money too much' - by 'the Chinese', he actually meant Chinese Koreans who had gone to Russia for business. I objected to his generalization, saying that I knew a typical Chinese Korean woman in Ussuriisk in the RFE who was not greedy at all, but instead very kind and trustworthy. The guesthouse owner was not convinced. He carried on giving examples of his low opinion of the Chinese Koreans he had known in northeast China, listing all kinds of unfortunate cases of betrayal and deception of his own folk, South Korean businesspeople. ${ }^{1}$

Talk of betrayal inevitably invokes the issue of trust. In one story, Mr. Bae described how a South Korean man had lost all his money and possessions when he was deceived by a Korean Chinese woman who had helped him open a factory and buy a house in a small city in Heilongjiang Province, but had then switched the ownership of the house and factory to her male sibling. This happened because he had trusted the woman enough to let her to deal with important financial matters. He had come to China as a wealthy businessman and ended up by losing his money and betrayed by a woman he trusted. I responded with a gasp: 'How could that happen?' Mr. Bae shocked me by replying, 'You have just said that you trust that Chinese Korean woman in Russia, haven't you? He also trusted the woman, just as you do.' He then implied that trust can only be maintained when economic interests are not involved, and that it can easily turn into betrayal when money or other economic matters are intermingled with trust. He added that trust is only really sustained when two people have children together. This observation manifests a folk intuition about what constitutes the vulnerability and resilience of social relationships based on human bonds.

This paper aims to further explore the complexities of trust in crossborder market situations. Its focus will shift to a different context: the souring of trusting relationships between two branches of Koreans in the RFE, the Chinese Korean incomers and the long-settled local Russian Koreans. What Mr. Bae had implied was that trust and treason are complementary

1 For an extensive record of such occasions, see Kim (2010). There is increasing research, mostly in Korean, on the relationship between South Koreans and Chinese Koreans in both China and South Korea. 
and indispensably inherent properties of social relationships, rather than separate and independent opposing terms. This insight can be related to Ernest Gellner's contribution to an edited volume on trust (1988), in which he challenges two perceived assumptions about trust and social cohesion. First, Gellner argues that the absence of governance by state authority may engender social cohesion. This claim in effect refutes the Hobbesian characterization of society, in which the absence of an absolute ruler is assumed to put societies into a state of chaos or generalized distrust. Gellner, by contrast, argues that the absence of an overall governing polity creates social cohesion through bonds of trust among kinsmen, taking his example from pastoral societies in arid zones. His other interesting argument, which also challenges the conventional understanding of trust, is that the social cohesion based on this kind of trust is nevertheless fundamentally subject to treachery, especially in certain cultures. Furthermore, 'treason within it [a society such as Arab tribes] performs the same role that price changes perform in a market society. It helps to maintain equilibrium through realignment' (my emphasis) (Gellner 1988, 146). Thus, I infer that Gellner is suggesting that trust and treachery co-exist and may in fact be two cogwheels, which enable some non-state societies to work despite the absence of government or regulatory authority'.

In my view, this idea could well be applied to societies in the Russia-China borderland, where the states' reach is intermittent. Governments find it hard for the regulating administration to reach the margins due to their remoteness from the centre of the state power. Although 'political remoteness' is not in principle necessarily geographical, in the sense of measuring the distance between the centre and the borderland, nevertheless the vast territory of the two countries under consideration in this paper - China and Russia - makes geographical remoteness particularly problematic for central powers attempting to govern their peripheries. In fact, the ending of socialist regimes in both countries left the borderlands on both sides particularly anarchic, especially in terms of the absence of a regulating power over cross-border activities. ${ }^{2}$

The equilibrium Gellner referred to was that between sub-groups of tribes and groups of kinsmen. In this paper, I discuss transactions across the Sino-Russian border between different groups of Koreans. I will examine how 'trust' and 'treachery' are enacted and narrated in inter-personal relations, and in what conditions a relational equilibrium between actors is

2 In Park (2016), I discussed cross-border trading in this region with a focus on the state's policy orientation. 
maintained or breaks down. My focus will be on a kinship category called 'bon', which can provide an integrative framework for these relations in some kind of equilibrium. I will argue that, rather than assuming the disjunction between sub-groups of Koreans in advance, it is the unsettling of the equilibrium that leads to the separation of sub-groups.

As the introduction to this edited volume suggests, trust goes handin-hand with calculations in inter-personal relationships. As I will argue, mutual economic interest sustains relations in the framework (or guise) of trust, and this facilitates the local economy of the borderlands. It is therefore important to ethnographically explore the precise character of such slippery socio-economic relationships. When does economic calculation, rather than trust based on moral norms, emerge as dominant, and vice versa? Economic reasoning may support trust, or on the other hand it may suggest that mistrust would be more rational. I suggest provisionally that the latter realization emerges when the potential for future mutual interest fades away, a situation that is usually brought about by wider social and political conditions rather than by either the immediate economic transactions between two parties or by the affective aspect of their social relationship. This observation arises from the particular case of the recent demise of the Chinese-operated market in Ussuriisk, a border city in the RFE. The collapse occurred through the increasing intervention of the Russian federal state into the local border economy (until the early 2ooos the border economy had been self-governed locally and was in effect outside the administration of Russian federal authority). More generally, in comparative perspective, this changing situation provides an interesting arena in which to explore Gellner's ideas on government, trust, social relations, and the economy.

\section{Background: historical ties and dis-connections across the border}

The vast majority of both the Koreans in northeast China ${ }^{3}$ and the Koreans in the $\mathrm{RFE}^{4}$ originated from the northern region (especially Hamgyeong Province) of current North Korea, which borders China and Russia. Due to the limited space and scope of this paper, I am not able to discuss the history of these two branches of Koreans in detail, but still a brief note on their

3 They are known as Chiaoxianzu in Chinese and Joesionjok or Joseon saram in Korean. I call them Chinese Koreans in this paper.

4 They are called Koreets (pl. Koreitsy) in Russian, and call themselves Goryo saram in Korean. However, I will call them Russian Koreans in this paper. 
history is required: their connectivity, dis-connection, and re-connection across the border over the last one and a half centuries is relevant for the present situation. ${ }^{5}$

Of all the more than seven million overseas Koreans, these two groups (totalling more than two million people) probably share the most common features. Firstly, they shared regional, temporal, and occupational (probably interchangeable with 'class') origins when they migrated to northeast China and the RFE. As Hyun Ok Park (2011) has noted, these migrant Koreans can be called 'colonial diasporas', in that their displacement coincided with the colonization of Korea (then the Joseon Kingdom) by Japan from the late 19th century onward. Although there were some exceptions, such as political exiles, who had a higher social status and more diverse regional backgrounds, the vast majority of the early migrants were poor peasants from the northern part of Korea. Later, in the 1930s, the regional origin of Korean migrants expanded to include the southern provinces (Jeolla and Kyeong-sang Provinces) of Korea; many of these people ended up travelling further into the northern Heilongjiang Province of China, as the Yanbian region of Jilin Province that is adjacent to the Korean Peninsula was already settled by the earlier migrants from the northern provinces of Korea. These differences in local origin from the Korean Peninsula still appear as a certain cultural difference between the Chinese Koreans in Yanbian Autonomous Region and in Heilongjiang, which has been further reinforced by the difference of provincial administration in China. Yanbian Koreans, for example, take great pride in the fact that they are from a national autonomous region. Nevertheless, the majority of Koreans in both northeast China and the RFE came from the northern region of Korea, and historical research shows that these two branches of Koreans transacted with each other until 1937.

Along with the political ties among anti-Japanese socialist partisans, kinship ties were the basis for the transactions between the two branches of Koreans across the Sino-Soviet border, a situation that remained until the Russian Koreans were deported en masse to Central Asia in 1937. During my fieldwork in the RFE, I heard testimonies from Russian Koreans about retaining ties with relatives in northeast China until 1937. Indeed, suspicion of cross-border ethnic ties with Japanese-occupied Korea and with China

5 There is an increasing literature on Chinese Koreans, not only in Korean but also in English. In English, the first monograph-length work was written by Olivier (1993), which focused on the implementation of the Soviet-influenced nationality policy in Yanbian Korean Autonomous Region. This was followed by other significant sociological and anthropological works such as Park (2005; 2015), Freeman (2011), and Kim (2013). 
was the main reason for the deportation (Martin 1998; Chernolutskaya 2011). The massive out-migration of Koreans from the RFE to China during Soviet collectivization - numbering around 50,000 in the late $1920 \mathrm{~s}$ - was taken as clear evidence that the Koreans were not 'reliable', and hence must be cleared from the border region and relocated by the Soviet authority (cf. Wada 1987).

Despite the wholesale removal of RFE Koreans to Central Asia in 1937, they were able to revive some kinship ties across the border when some Koreans returned to the Far East in the late 1950s after the death of Stalin. However, next it was the Chinese side that became suspicious of treachery; a second cessation of cross-border ties happened during the Cultural Revolution and the Sino-Soviet split. ${ }^{6}$ One elderly man in Yanji (Yanbian Province) told me that his parents had to denounce themselves in a sogo ('public confession') during the Cultural Revolution for having received some factory goods as gifts from his father's sister's family who had returned to Khabarovsk from Central Asia (my fieldnote, May 2012). The complete closure of the Sino-Soviet border after the late 1960 s conflict between China and Russia about the Damanskii Island in the Ussuri River ensured that connections between Koreans across the border became virtually impossible.

After decades of separation during the Cold War, the two groups of Koreans, Chinese and Russian, came to have very different cultural features. This was despite the many things they had in common, such as the same provincial origin in Korea and both being located as diaspora minorities in socialist countries. It was only with perestroika and the subsequent opening of the border between China and Russia in the early 199os that these two groups of Koreans were able to meet again. At this point, many Koreans returned from their Central Asian exile to the Russian Far East. Various transactions across the Sino-Russian border were then set up, and some Chinese Koreans moved to the RFE to do business, but all of this was in a very different context than in the past.

\section{Repairing elapsed ties: the question of whom to trust}

One icy cold morning in December 2002, I went to a Japanese second-hand car market on the outskirts of Ussuriisk to buy a car. A Chinese Korean boy called Sasha (then aged 18), whom I had gotten to know at the Institute I was affiliated with (he was learning Russian language) was keen to accompany

6 See Hyun Ok Park (2015, Chapter 5) for a more detailed discussion on memories of the Cultural Revolution in Yanbian Korean Autonomous Province. 
me, as he liked cars and was dreaming of driving one for himself, as a young man typically does. Immediately upon entering the car market I was overwhelmed by the large scale of the place and the sheer number of car sellers. I did not know where to begin. In contrast to my confusion and bewilderment, it seemed to be very simple for Sasha to know what to do. Without hesitation, he directly approached an East Asian looking woman and began to talk in a strong dialect of Korean (from Hamgyeong province) that he had not used at all in conversing with me (he spoke in the standard South Korean accent). Although we ended up buying a car from another dealer, not from the Russian Korean woman he had initially addressed, the way he approached buying a car shows a certain general tendency among Chinese Koreans when they initiate economic transactions in strange places. I suggest that it would not be absurd to assume that the Chinese Koreans who first crossed the border might also have begun their trading activities in this way.

Chinese Koreans proactively approached Russian Koreans, and the language they normally used was dialectal Korean. This pattern of initiating transactions, i.e., Chinese Koreans' more proactive approach, was due to certain demographic features concerning the Koreans in China and the RFE and the predominance of Slavic people in Primorskii Krai, Russia. There is a great imbalance: the number of Chinese Koreans is nearly 2 million in northeast China, ${ }^{7}$ while the number of Koreans in Primorskii Krai is 18,824 , according to the 2010 census. ${ }^{8}$ However, the actual number of Chinese Koreans in Primorskii Krai is unknown, as they are considered to be Chinese citizens when they cross the border, and are mentioned as such in the local authority's statistics on migration. In the town of Ussuriisk, where I was mainly based during my fieldwork, the proportion of Chinese Koreans among the traders in the Chinese market was approximately 40-50 percent in 2002-2004, as conjectured by my Chinese Korean acquaintances. But I could see that Koreans appeared to be taking the leading roles in creating and administering the market. For example, the partners of the limited company Ussurii Tsentr, which owns and manages the Chinese market,

7 A large number of these Chinese Koreans moved to South Korea for migrant labour after 1992, when diplomatic relations were established between South Korea and China, leaving the Yanbian region populated with many fewer Koreans than in the past.

8 This is much smaller than the number estimated by the Koreans themselves. In 2001, a Russian Korean civil organization estimated that around 40,000 Koreans were living in Primorskii Krai (Troyakova 2004), and some Russian Koreans told me that that around 10 percent of the Ussuriisk population is Korean, i.e. around 10,00o. This is not a verified number and could be an overestimate, but it can be read as a statement on the significant presence of Koreans in the city. 
include a Chinese Korean man, a Russian Korean (supposedly a powerful Mafioso), and a Russian man who was a former communist party member and also a high official of the railway operators' union. ${ }^{9}$

Accurate data for the number of Chinese Koreans in Russia are not available; this unidentified number tells something interesting about the flexibility of their belonging. Their double belonging - being Chinese citizens by jurisdiction and Korean by culture and history - is particularly useful for entrepreneurship and the creation of a flourishing border economy. In other words, although Chinese Koreans are categorized as Chinese in the official migration statistics, when they cross the border into Russia they tend to present themselves as Koreans during their actual economic and social transactions, particularly when they encounter Russian Koreans. However, this common origin, usually expressed by using dialectal Korean, is not something that all of the Russian Koreans always welcome and embrace for themselves. From the Russian Koreans' perspective, it is nearly impossible to discern the difference between the Han Chinese and Chinese Koreans unless the latter begin to speak in Korean, since all Chinese citizens, including minorities, are lumped together as 'Chinese' - not only in the authority's statistics, but also in the public perception of the local residents.

In fact, it was a burden and tension for the Russian Koreans to accept the affection emanating from the Chinese Koreans. In general, their attitude toward the Chinese Koreans was much more cautious than that of the Chinese Koreans toward them, mainly because of the general public perception of 'the Chinese'. When anti-Chinese sentiments were high in the RFE in the 1990s and early 2000s, it was common for Russian Koreans to display their differences from the Chinese Koreans, highlighting their pride in belonging to the Soviet Union and their appreciation of Russian culture (see Park 2013). Many adopted the Russians as their model: for example, a businessman who was collaborating with the Chinese Koreans for the export of wood to China said in a meeting with some South Korean NGO delegates, 'Just as the behaviours (povedeniia) of the Chinese Koreans resemble those of the Chinese, ours are similar to the Russians' (rossiiany)' (my field notes, February 2003).

9 A triangular collaboration among the same three parties - a Chinese Korean, a Russian Korean, and an ethnic Russian working for the local authority - seems to be the basic combination pursued for 'big' businesses in the RFE, according to my informants in Dongnying in Heilongjiang Province (my field notes, May 2012). My paper (Park 2013) discussed a triangular collaboration between three groups of Koreans - Chinese Koreans, old resident Russian Koreans, and newcomer Russian Koreans - in the RFE in the 1990 . 
In the early 2000s, many Russian Koreans were in fact able to quickly accumulate wealth through collaboration with Chinese Koreans, but these enterprises hardly emerged onto the surface and were not acknowledged publicly. Instead, rumours about the 'Korean mafia' became widespread. This meant that many Russian Koreans, especially those who lived in urban areas, became extra cautious, since they were anxious about being targeted by Sinophobia like they had been in the late 1960s during the border clashes between China and Russia. In recent years anti-Chinese sentiments have diminished and the encompassing category of 'the Chinese' has begun to be dismantled. Accordingly, Korean media such as the local newspaper published by the National and Cultural Autonomy of Koreans in Ussuriisk (May 2014 Koryo Sinmun, 1) which had previously rarely included any article on the Chinese Koreans, now highlights their contacts and popularizes tourism from Russia to the Yanbian Korean Autonomous Prefecture, and especially to the Chinese border town of Hunchun.

One of the important arguments of Edmund Leach's Political System of Highland Burma (1971) is that inter-tribal relations must be considered to understand the historical changes in the social structure of certain groups of peoples. In this light, I would like to examine a structural rule that is available to define the insiders and outsiders of the imagined consanguineal groups among the Koreans. While Leach discussed the political models of gumsa, gumlao, and Shan as the ideal types of egalitarian and more hierarchical political orders, the Chinese and Russian Koreans' conundrum in hovering between two modes of being (citizenship and ethnic belonging) hinges not on models of power, but on the contrast between the moral values of humanity and calculative economic reasoning. It is their choices in this situation that invoke, or on the other hand destabilize, their identification of each other as 'the same people'. This problem is the most acute for the Chinese Koreans, who try to show a certain favour toward their co-ethnic Koreans in the RFE as a token of humane intimacy towards them: i.e., they assert the affinity between themselves and the Russian Koreans, and expect a similar attitude from Russian Koreans in return. It is in this 'ethnic mode' that trusting economic relationships may well be orchestrated if the actor wants to create a long-term and close relationship for serious business ventures rather than a one-time transaction for small commerce. However, most encounters are temporary, and the general tendency in such ephemeral transactions is still largely defined by the contours of the negative public image of 'Chinese traders' in general. It is not just that customers hold this image, but that the sellers conform to it by differentiating their practices. For example, Chinese Korean traders tend to say that, when they sell goods to 
non-Korean customers (with whom they seldom create long-term partnerships), they have the same trading policy as that of Chinese traders: to try to gain as much as profit from the sale as possible with arbitrary and high pricing. They are less likely to do this with Korean customers. Nevertheless, the prevalence of temporary transactions even with the latter could be a reason for the limitations in forming any closer social relationships, which require something to be considered above and beyond economic interest.

This pricing practice, together with the low quality of the goods, was one of the main causes of the rise of anti-Chinese sentiments among Russians. Traders were considered to obmanut' ('cheat') the customers, leading to public distrust of all 'Chinese traders'. ${ }^{10}$ As recent research by Stern (2015) shows, this perception had a consequence: it caused hostile bargaining tactics to be adopted by Russian shoppers in the Chinese border town of Manzhouli. The Russian customers rudely ask for ridiculously low prices, thus arousing the rage of the Chinese traders in the town, who in turn demand 'respectability' from the Russian shoppers in the framework of the Chinese idea of wenming ('civilization') (Stern 2015; see also Peshkov, this volume).

Of course, there are political-economic reasons for the totally different level of pricing in China and just across the border in Russia. It was the large divergence in the cost of living in general between the two countries that enabled cross-border trade to be so lucrative. In other words, due to low costs in China the profit margin of the Chinese traders was extremely high in the RFE; this gave the Chinese traders more room to set prices at will, i.e., the trading was still profitable even with big discounts. Thus, the price of goods was not based on the exchange value of the commodity, but on the feelings of the traders towards each given customer. This is why Sasha, the boy I mentioned at the beginning of this section, approached the Russian Korean car dealer with the assumption that for him the price of the car would be reasonable and its condition trustworthy. However, as I show later in this paper, the spontaneous trust expected from co-ethnic people does not necessarily explain the flourishing of a border economy boosted by the collaboration between Chinese and Russian Koreans, and it is also of limited use for understanding the recent demise of this border economy. While Stern's case shows that cultural misunderstandings between Russian

10 One of my informants in China, a young Han Chinese trader in Hunchun, told me that such pricing practices - stating a higher price keeping in mind further negotiation with the customer - were considered normal 'bargaining' by the Chinese traders, but he was well aware of the Russian customers' perception of them as cheating. 
shoppers and Chinese traders concerning price negotiations and civilized commercial behaviour may have been a factor leading to the decline of border trading in Manzhouli, a description of retail scenes cannot explain the formation and change of the border economy at levels other than trading. It is necessary to explore economic transactions at a deeper level, not merely at that of transactions between sellers and customers. This is why I am moving on to discuss bon, one of the relational terms from which deeper trust can be grown.

\section{Reconnecting kinship ties across the border: the meaning of bon}

The central kinship relation under consideration is an indexical genealogical term called bon (not italicized hereafter). ${ }^{11}$ One common perception of the social relationship between the Chinese and Russian Koreans (but differentiating these diasporic Koreans from Koreans in the Korean Peninsula) is their particular emphasis on bon. What is bon? In Korean custom, first names are diverse and numerous, but there is only limited number of surnames. Each surname consists of several bons..$^{12}$ In short, bons are branches of family names. In South Korea, the social implication of bon lies only in its function of regulating exogamic marriage, not for forming a descent group - and even that exogamous function is vanishing since the 2005 amendment of the law prohibiting marriage among people who share the same bon. Bon was used to proscribe unmarriageable people, and was only rarely used to define descent groups by lineage because there were other social categories for the consolidation of kinship groups other than people with the same bon. ${ }^{13}$ It is usually the descendants of a famous ancestor, e.g., someone recognized with high status by the government or for their academic achievements, that form a descent group, usually accompanied in the Chosun period by the grant of a parcel of land from the king. Thus in South Korea descent groups are based on corporate land rights, ancestor worship rituals, and a written genealogical record. It was because I, as a South Korean, had this idea in mind that I did not at first take advantage of my bon during my fieldwork. In the Chinese

11 A more popular term in South Korea is bon-gwan, and is also called bonhyang or gwanhyang. However, Russian Koreans only use the term bon. Here, I adopt their usage.

12 According to the census in South Korea in 2000, there were 286 surnames and 4,179 bons. Technically, it is possible to found a new bon, particularly when a foreigner is naturalized as a South Korean citizen. The place name (bon) can be decided by the person who founded the bon. 13 However, for research on the mobilization of lineage groups based on bon in modern South Korea, see Kim (2014). 
market I met a young woman who discovered that we share the same bon, Hamyang (most Parks have Milyang as their bon). When she discovered this, she exclaimed, 'We are relatives!' and gave me her mobile phone number, asking me to get in touch with her for soobshchenie ('socializing'). When I was growing up, it was not bon (place name) that mattered for our descent group, but a great ancestor who was a well-known Confucian scholar. I was often told that I should be proud of being a descendent of that great ancestor. I did not take her proposal seriously due to my own presumptions about kinship groups, and I regretted it later on.

After their displacement from the Korean Peninsula, the diasporic groups of Koreans in China and Russia did not have any of these territorial, ritual, or knowledge bases on which to form corporate kinship groups. This is why, I suggest, bon became a more meaningful kinship category for them, and a basis for developing intimate and affective kinship-like relations. Very often co-ethnic encounters lead to speculation about the commonalities shared between the two parties, including the bon if the two people happen to have the same family name. In the case of Russian Koreans, it must also be taken into account that the effect of their second and third displacements, from the RFE to Central Asia and back to the RFE, deprived them of the possibility of consolidating other traditional kinship bases such as common residence or continuous social interactions. These people not only experienced dispersed residence, displacements, and urbanization during Soviet times, but also lack any Korean territorial autonomy inside Russia. This is why the meaning attributed to bon is stronger for Russian Koreans than for Chinese Koreans, who at least have an autonomous region and live fairly compactly in northeast China. ${ }^{14}$ Although the Chinese Koreans are also distant from their original homeland, they have put down more roots: in the rural areas of their region there are still some lineage-based villages of Koreans composed of people with the same family names and bon (I discovered one such village in Dongnying County in 2012).

Thus we may conclude that the fact of having migrated is not a unitary social feature, but carries different historical configurations; to simplify, the more severely uprooted the group, the more emphasis they place on the social function of bon. What is most interesting about bon is its connection with a place of origin. The bon can be a highly effective signifier for the origin of a kinship connection, the imagined sharing of not only consanguinity but also of the soil of origin. Bon is in fact a place name in Korea,

14 The mobility of the Chinese Koreans out of northeast China only began in the 1980s, with the opening and reform policy of the state. 
where the founding father of each bon (an ancestral figure) originated. For this reason, bon can potentially be an effective social vehicle for diaspora people to make a path towards the wider world beyond their households, as it provides them with the ground for an imagined connection with a place other than the territorialized space regulated by nation-states. This is especially important considering these diasporas' unorthodox belonging to the several nation-states (Russia, China, and North/South Korea) with which they are entangled. This, in brief, is why many Russian Koreans consider bon to be their place of origin beyond the known birthplace of their immediate forefathers, even though this notion is absent in South Korea.

For example, my interlocutors tended to list the birthplaces of their parents, grandparents and, in some rare cases, great grandparents, and then they would wonder whether the place of their bon might be the origin of their ancestors about whom they have no further knowledge. In their critique of the neoliberal promotion of ethnicity, John Comaroff and Jean Comaroff $(2009,42)$ also discuss the component of place in compensating for the lack of genealogical knowledge of black diaspora individuals, as provided by genome-sequencing companies in the USA. American celebrities like Oprah Winfrey and Whoopi Goldberg have 'discovered' their African roots through DNA sequencing, the former in 'the rainforests of Liberia' and the latter in a 'forgotten corner' of Guinea-Bissau (cited source omitted, Comaroff and Comaroff 2009, 42). These places 'discovered' by DNA analysis were extracted and conjured up to produce a personal identity. For Russian Koreans, on the other hand, the importance of bon lies more in its definition of sameness/difference in social relationships than in its production of an individual identity. Most important for this paper, bon can become an effective vehicle to create imagined connections among Koreans across state borders, superseding differences such as citizenship, economic standing, and social status.

\section{Establishing Deep Trust - and a Betrayal}

It was in this context that my key interlocutor, who I will call Mrs. Kim, a Chinese Korean woman born in 1950, expanded her business beyond her retail stall in the Chinese market in Ussuriisk by resorting to the Russian Korean notion of bon as the basis for trust and intimacy. ${ }^{15}$ In the previous

15 Chinese Koreans also show intimacy towards people with the same bon (Kwon Junehee, personal communication by email, 5 February 2016), but the prospect for bon-based relationships to develop further is greater among Russian Koreans. 
section, I discussed co-ethnic encounters between Chinese Koreans and Russian Koreans as retailers and consumers across the border. Those transactions in marketplaces and shops tend to be not only temporary but also largely circumscribed by the general atmosphere of anti-Chinese sentiment. In other words, stronger and more enduring business partnerships are not guaranteed simply because both parties are Korean.

Mrs. Kim was clearly aware of the need for trusting relationships with Russian Koreans to pursue business opportunities in Ussuriisk. Before she settled in Ussuriisk, she had carried out typical shuttle trading to Central Asia and southern Siberia. So when she perceived the need for a kinshiplike relationship with a Russian Korean, she dispatched her husband to Kazakhstan, to bring over a woman she had met during her trading trips to Central Asia who had the same bon as Mrs. Kim. Although her family name, Kim, is the most common, the majority of Kims have the bon Kyungju; her bon, Kwangsan, is neither rare nor common. So Mrs. Kim's husband went to Central Asia and brought another Mrs. Kim to Ussuriisk in mid-1995. Mrs. Kim called this woman brought from Kazakhstan her hyung-nim ('sister'), and she helped her quasi-sister settle in Ussuriisk, including buying a house for her at USD 800 which would now be valued at more than ten times that price. ${ }^{16} \mathrm{My}$ interlocutor Mrs. Kim needed help from somebody she could trust, as she had not only bought a flat with the intention to permanently settle in Ussuriisk, but also because she wanted to expand her business beyond the Chinese market. In both cases, help from a native Russian speaker who also knew the law was absolutely necessary (Mrs. Kim is not literate in Russian, though her spoken Russian is quite fluent).

During my first stay in Ussuriisk in the early 200os, the Chinese market was flourishing and had expanded beyond the territory of the marketplace with the development of additional houses and shopping malls. With her excellent business acumen, Mrs. Kim was exploring wider business opportunities in two directions. One was the expansion of her retail business into the wider Russian market; the other was the development of a property that would target the increasing number of Chinese traders. In 2003 she was able to secure a boutique in a large newly opened supermarket near the Chinese market. At the same time, she bought a plot of land just beside the

16 After the early 2000s, Russia saw drastic inflation; the RFE had one of the highest inflation rates in the country. The price of a loaf of bread was 5 roubles in the early 2000 and rose to 30 roubles in 2010. The price of properties rose much higher than the inflation rate, leading to a development boom in the urban areas of Primorskii Krai. 
Chinese market. For this complex and risky process of property purchases (see Humphrey, this volume) - her flat and the land plot -,it was obvious that she needed some help from the other Mrs. Kim and from other Russian Korean acquaintances. When I re-visited her in 2010, she had withdrawn her retail business from the supermarket (which had been burnt down in a fire) and had instead opened a guesthouse for Chinese traders, built on the plot she bought in 2000. To finance the building of the guesthouse, she had sold every valuable she possessed, including her flat, a stall in the Chinese market, and her much-loved Suzuki four-wheeled jeep. The guesthouse proved to be very profitable, bringing her a large cash income from renting over 60 rooms to Chinese traders; in 2010 she was able to charge a monthly rate between 5,000 and 10,000 roubles, which quickly returned her investment. ${ }^{17}$

However, when I visited her again in autumn 2013, she was selling her guesthouse and preparing to return to her hometown of Yanji in China. The immediate reason for the sale of the guesthouse was the unexpected deportation of her husband, who had overstayed his visa by two days, mistakenly remembering the wrong expiry date of his visa. Due to these two days of unlawful stay in Russia, he was not allowed to enter Russia for the next five years. Although it would not have been impossible for her to run the guesthouse on her own by employing people who would do the repair and maintenance jobs her husband used to do, she told me that she was 'fed up with Russia' and 'didn't want to live in Russia any longer'. ${ }^{18}$ She listed many reasons for her 'sickness' with Russia, including deploring 'hopeless Russia' when she contrasted her experiences of buying properties in Yanji and in Ussuriisk. In spring 2013, she had bought two new flats in an emerging popular residential area in Yanji, where the purchasing process was 'so easy and simple' requiring only 'one thin envelope of documents',

17 In early 2008, the central government of the Russian Federation enacted a law forbidding foreign nationals from working as traders or retail staff. This legislation was followed by the investigation of the visa status of traders in the Chinese markets; many had only tourist visas and were deported. The result was a dramatic decrease in Chinese traders. However, Mrs. Kim's guesthouse was still full, thanks to its convenient location to the Chinese market and better living conditions, compared to other guesthouses.

18 However, she also noted her attachment to Russia, which formed during the last two decades of her stay in Russia. She felt herself to be so different from other Koreans in Yanji - who had mostly only been to South Korea for migrant work - to the extent that she cannot communicate with them well. She also said that she would miss all flora and fauna she loved, including the wild vegetables and mushrooms she used to gather or buy in the spring and summer season that are so clean and safe to eat, but which are not available in China. 
whereas she had had to process 'two suitcases of paperwork' in order to build her guesthouse in Ussuriisk.

Saddest of all, she dwelled at length on the betrayal of her adopted sister, the other Mrs. Kim from Kazakhstan. After the completion of the guesthouse, she discovered that her adopted sister had registered the place as a hotel. The problem with this was that it invited frequent inspections from various local regulating authorities such as for hygiene and fire safety, resulting in her having to pay a large number of bribes to the civil servants. She would have been happy to give bribes to policemen who might be called in the case of violent incidents at the guesthouse, but this was too much. Furthermore, Mrs. Kim suspected that her adopted sister had taken some financial advantage as a mediator with the civil servants. More absurdly, Mrs. Kim from Kazakhstan had demanded half ownership of the guesthouse. This was based on her claims about her contribution to the construction and opening of the guesthouse, but did not take into account the various financial favours given to her by Mrs. Kim from Yanji, including the purchase of her house when she settled in Ussuriisk. Later, Mrs. Kim found out that it had not been necessary to register the guesthouse as a hotel: it would have been possible to register the guesthouse as a private house, which she could have done herself without drawing constant attention from the bureaucratic authorities. Mrs. Kim was deeply disappointed and upset by the fact that this person who had the same bon with her, and with whom she believed that she forged a quasi-siblingship that she had fostered over the past two decades, had not taken account of her interests - which evidently amounted to a dismissal of mutuality (Gudeman 2008).

\section{Social Shifts: Difference and Hierarchy}

The most remarkable change in Chinese Koreans' perceptions of their lives in Primorskii Krai over the last two decades, exemplified by the personal business story of Mrs. Kim, lies in the creation of a clear boundary between themselves and the Russian Koreans. Now the Chinese Koreans emphasize their differences, rather than the similarities they so warmly highlighted in the early 2000s. In effect, a new social group has emerged. After two decades' residency in Russia, they extended ethnic typecasting to other groups of people around the Chinese market, who fall largely into three categories: 'black people' (黑毛子hēimáozi), who are from Central Asia; 'Russian people' (露毛子 romaozi in pidgin Chinese-Korean or mauje in the 
Hamgyong dialect of Korean, meaning Slavs); and 'second-rate people' (二毛 子 èrmáozi in Chinese), referring to Russian Koreans. ${ }^{19}$ In the 1990 os and until the early 2000s, the Russian Koreans had been referred to respectfully as rossia Choseonjok ('Russian Korean people') to denoting their commonalities, but recently the derogatory term 'second-rate people' has become widely used among the Chinese Koreans who have any direct or even indirect experience with them. Mrs. Kim made her own hierarchical evaluation of these three groups in terms of trustworthiness, in the order: 'black people', 'Russians', and then 'Russian Koreans'. In other words, Mrs. Kim had concluded that 'Russian Koreans' are the worst people she encounters. They are people who do not value the trust placed in them, but are only interested in maximizing their own interests. Indeed, taking action based on this hierarchy, she sold her guesthouse not to a Korean but to a black person', a man from Central Asia, for USD 1.7 million in 2013.

\section{Conclusion}

I understand the betrayal Mrs. Kim felt from her quasi-sister as another affective indicator enabling her to make sense of her business experience in the obscure process of evaluating her future business prospects in Russia. Hypothetically, I think she would have continued her business in Ussuriisk, despite the untrustworthiness shown by the other Mrs. Kim, if the business had been guaranteed to continue successfully. It must be noted, however, that the Chinese market dramatically declined after the central government began to launch its own development initiatives in the RFE (Figure 9).

There were frequent raids on the Chinese market and tighter control of migrants through stricter visa regulations and the cutting of local connections across various sectors, such as with local authorities, wholesale businesses, logistics agencies, etc. I suggest that the fracture in the relationship between two Mrs. Kims of the same bon can be seen as the unsettling of the equilibrium between trust and calculative reasoning that had formed the core of their mutuality, but that the collapse of this mutuality did not really come from this betrayal but from the absence of a prospect of a 'shared interest' in future business in the RFE, i.e., from the gloomy prognostication that 'the Chinese market is dying'.

19 Máozi is a derogatory term for Russians, and Europeans more generally, that is popularly used only in northeast China. It literally means 'hairy bastards'. It is notable that both people from Central Asia and Russian Koreans are considered to belong to the Russian category. 
Figure 9 Chinese market in Ussuriisk, 2016

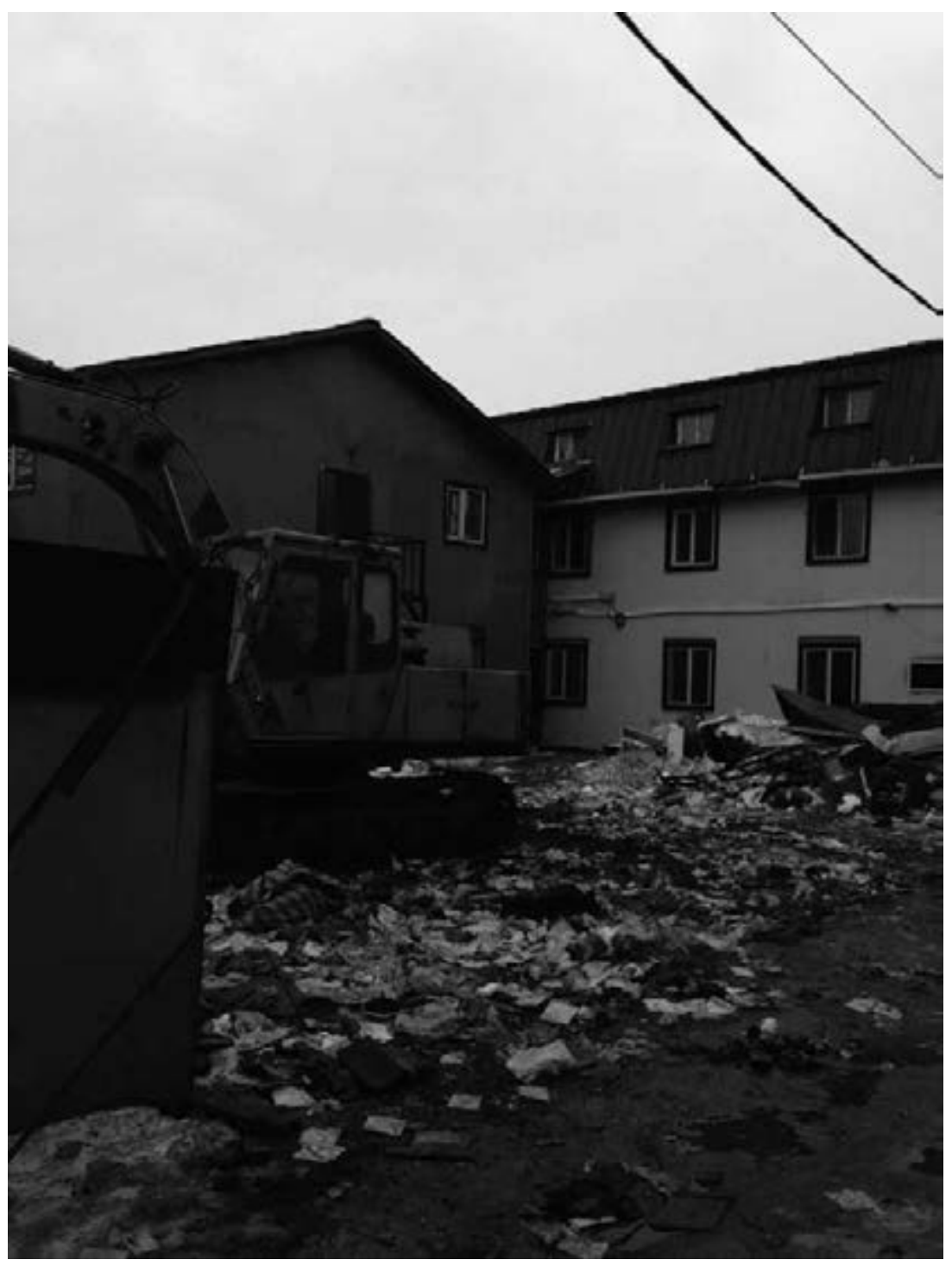

Earlier, it had been the precarious balance of the mutuality of two parties across the border that had enabled the frontier market economy to be sustained and flourish. In accounting for what happened next, it is useful to refer to Gellner. According to him $(1988,143)$, it is often the state 'that destroys trust', replacing the delicate equilibrium of social cohesion with 
harsh controls set by the government. This idea applies to the role of central government in the case of the RFE, an example being what is now happening in the Chinese market in Ussuriisk. The central government is obliterating the hope in the future that allows trust to rise again, and in the process it is destroying the local economy.

\section{References}

Alexseev, Mikhail A., 2001. Socioeconomic and Security Implications of Chinese Migration in the Russian Far East. Post-Soviet Geography and Economics, 42(2), pp. 95-114.

Alexseev, Mikhail A., 2006. Immigration Phobia and the Security Dilemma:Russia, Europe, and the United States. New York: Cambridge University Press.

Billé, Franck, 2015. Sinophobia: Anxiety, Violence, and the Making of Mongolian Identity. Honolulu: University of Hawaii Press.

Chernolutskaya, Elena N., 2011. Prinuditel'nye Migratsii Na Sovetskom Dal'nem Vostoke v 1920-1950-E gg. [The Forced Migrations in the Soviet Far East in 1920s1950s.] Vladivostok: Dalnauka.

Comaroff, John L. and Jean Comaroff, 2009. Ethnicity, Inc. Chicago and London: The University of Chicago Press.

Dyatlov, Victor I., 2000. Anti-Immigrant Attitudes in the Socio-Political Life of a Siberian City: The Example of Irkutsk. Inner Asia, 2(1), pp. 13-24.

Dyatlov, Victor I., 2012. Chinese Migrants and Anti-Chinese Sentiments in Russian Society. In Frontier Encounters: Knowledge and Practice at the Russian, Chinese and Mongolian Border. Cambridge: Open Book Publishers, pp. 71-87.

Freeman, Caren, 2011. Making and Faking Kinship: Marriage and Labor Migration between China and South Korea. Ithaca, NY: Cornell University Press.

Gellner, Ernest, 1988. Trust, Cohesion, and the Social Order. In Diego Gambetta (ed.), Trust:Making and Breaking Cooperative Relations. Oxford:Wiley-Blackwell, pp. 143-57.

Gudeman, Stephen, 2008. Economy's Tension: The Dialectics of Community and Market. New York and Oxford: Berghahn Books.

Kim, Hyejin, 2010. International Ethnic Networks and Intra-Ethnic Conflict: Koreans in China. New York and London: Palgrave Macmillan.

Kim, Jaesok, 2013. Chinese Labor in a Korean Factory: Class, Ethnicity, and Productivity on the Shop Floor in Globalizing China. Stanford, California: Stanford University Press.

Kim, Kwang-Ok, 2014. Politics of Culture and Power Structure of Local Societies. Seoul: Seoul National University Press. [In Korean] 
Leach, Edmund, 1971. Political Systems of Highland Burma: A Study of Kachin Social Structure. London: Athlone Press.

Olivier, Bernard Vincent, 1993. The Implementation ofChina's Nationality Policy in the Northeastern Provinces. Lewiston, NY: Edwin Mellen Press.

Park, H.-G., 2013. The Migration Regime Among Koreans in the Russian Far East. Inner Asia, 15(1), pp. 77-99.

Park, Hyun-Gwi, 2016. One River and Three States: The Tumen River Triangle and the Legacy of the Postsocialist Transition. Asian Perspective 4o (3), pp. 369-92. Park, Hyun Ok, 2005. Two Dreams in One Bed:Empire, Social Life, and the Origins of the North Korean Revolution in Manchuria. Durham and London: Duke University Press.

Park, Hyun Ok, 2011. For the Rights of 'Colonial Returnees': Korean Chinese, Decolonization, and Neoliberal Democracy in South Korea. In Jesook Song (ed.), New Millennium South Korea: Neoliberal Capitalism and Transnational Movements. London and New York: Routledge, pp. 115-29.

Park, Hyun Ok, 2015. The Capitalist Unconscious: From Korean Unification to Transnational Korea. New York: Columbia University Press.

Martin, Terry, 1998. Origins of Soviet Ethnic Cleansing. The Journal of Modern History, 70(4), pp. 813-61.

Stern, Dieter, 2015. 'Nado Minimum!': Mediating Respectability at Informal Markets on the Russian-Chinese Border. Inner Asia, 17(1), pp. 5-30.

Troyakova, Tamara Gavrilovna, 2004. Koreiskoe Naselenie Rossiiskogo Dal'nego Vostoka: Osobennosti Mezhetnicheskikh Kommunikatsii [Korean Population of the Russian Far East: Particularity in Inter-ethnic Communication]. Unpublished manuscript.

Wada, Haruki, 1987. Koreans in the Soviet Far East, 1917-1937. In Dae-Sook Suh (ed.), Koreans in the Soviet Union. Honolulu: University of Hawaii Press, pp. 24-59. 


\title{
The Trade Town of Manzhouli
}

\author{
Trust Created and Undermined
}

Ivan Peshkov

Humphrey, Caroline (ed.), Trust and Mistrust in the Economies of the China-Russia Borderlands. Amsterdam: Amsterdam University Press, 2018

DOI: $10.5117 / 9789089649829 / \mathrm{PESH}$

\begin{abstract}
Manzhouli (Russian: Man'chzhuriya) had a complex 2oth century history as a railway town, smuggler's paradise, and military stronghold, but recently it has been specially designated as a border trade centre with Russia. Now China's busiest land port of entry, its population has shot up to well over 300,000 and its crowded, brightly lit shopping streets contrast sharply with the sleepy dullness of Zabaikal'sk, the Russian town just over the border. Manzhouli has tried to encourage trust by creating special areas and services (linguistic, logistical) oriented toward Russian traders, but at the same time the city undermines trust through what Russians consider dubious trade practices. The chapter provides a historical explanation of the Russians' entrenched suspiciousness. It concludes with a description of how both Chinese and Russians attempt to overcome these problems: by creating new images ('the good Chinese'), by using the Internet, and by using people from other ethnicities (Shinehen Buryats, Mongols) as mediators - but so far largely in vain.
\end{abstract}

Keywords: China, Russia, frontier urbanism, trust, mistrust

The relationship between trust and the conceptualization and use of urban border trading spaces has been little touched upon in the academic literature. This chapter addresses this gap, examining the creation and dissolution of trust in relation to the concrete spaces of a specific border town. Unlike the prevalent approach to trust, which understands it as an inter-personal cultural or social process (Cook 2001), here trust will be seen as an instrument for the 'taking over' of urban space, by both citizens and visitors. Conceiving of the discursive appropriation of urban space as 
involving choices along a scale from trust to mistrust, this approach makes it possible to demonstrate a direct link between such choices and other features of the border economy, such as Russian entrepreneurs' images of trade ethics, their view of the 'world on the other side of the border', and the possibilities for joint development of the region.

The main theme of this chapter will be Russian cross-border traders' open and hidden ideas concerning the appropriate conditions for business and leisure in Asia. These ideas not only reflect their evaluation of different kinds of space in general, but also determine their models for perceiving and appropriating specific urban spaces on the other side of the border. As Caroline Humphrey has observed, the everyday norms and values through which people attempt to understand the world around them can also, at the same time, be both the stimulus for economic action of one kind or another and a form of reaction to those very actions (Humphrey 2010, 111). According to Russian respondents, their criteria for good conditions for trade and leisure are obvious: relative security, low prices, and an adequate number of salespeople speaking Russian. But everything is not as simple as it appears.

As it happens, the Chinese border town of Manzhouli ${ }^{1}$ manifests all of these criteria in abundance. It was developed with Russian traders in mind, as a town of economic cooperation and friendship totally oriented toward visitors from Russia. Besides providing economic opportunities, the town is also a place of inexpensive and yet super-modern leisure facilities, which are particularly important for the weary folk who have experienced economic and social collapse across the border in Eastern Trans-baikalia. Despite this, trust and comfort are the last things in Russian visitors' minds. For them, Manzhouli is a place of ill fame, said to be a place created by the cheating, aggression, and greed of Chinese traders. The town is seen as a facade hiding the true nature of China: two-faced, non-understandable, and dangerous. No other Chinese city arouses such emotions in Russia like Manzhouli; no other town is spoken of so emotionally and harshly.

Why should a town that has done everything possible to accede to the demands of Russian entrepreneurs be seen by them as such an 'anti-place'? What were the unspoken expectations that resulted in such a negative opinion of the town? Why did the Chinese keenness to create trust result in

1 Manzhouli (Chinese: Manzhouli; Russian: Manchzhuriya) is a border town in the Hulunbuir prefecture of Inner Mongolia. It is the economic centre of the region and China's busiest point of land entry. In recent years its population has shot up to well over 300,000. 
the very opposite? Answering these questions requires us to pay attention not only to Russian attitudes toward Chinese traders, but even more to the urban spaces themselves that give rise to such feelings of danger and distrust among the Russian guests. As I will show, the imaginary projection of a dangerous place can give rise to distrust, irrespective of the policies of municipal leaders or the behaviour of the local inhabitants.

\section{Russian spaces in China: how post-colonial trauma transformed into neo-liberal hope}

During the entire 19th century, Russia was the active force in its relations with China; it was the main architect in redrawing the eastern border, and insisted on the undesirability of Chinese citizens' presence in the acquired territories. The combination of Russia's economic-military presence in former Chinese territory with the policy of protecting her Far East province from too much Chinese incursion was consequential: it led to the widespread expectation that Russia too, along with other imperial powers, would be found at fault by the Chinese during the century of their humiliation (Mierzejewski 2012). The Tsarist government saw the presence of Chinese subjects in its new territories in the Far East as a necessary compromise, required because of demographic shortfalls in its Asiatic provinces. The idea of the 'Yellow Peril', so popular at the time, can be seen as a consequence of the desire to de-Sinicize the region. Peter Holquist has described Russia's position during the last decades of the Empire as follows:

In studies of the Far East, Russian military statisticians, public activists, and government officials all singled out Chinese, both imperial subjects and aliens alike, as a particular threat. In addition to their growing numbers, the military men identified Chinese, like Jews, with commerce and the market, thereby conflating ethnic stereotypes with apprehension about the modern world. (Holquist 2001, 115)

The policy of 'cleansing' the border regions consisted of a complex of measures designed to ward off and control Chinese and Korean in-migration: the transfer of Chinese subjects to Russian legal jurisdiction (1883), removal of foreigners' right to settle in border areas (1886), a ban on employing foreigners in state projects (1910), liquidation of the Manchu enclave in the Amur Province (1900), and cancellation of untaxed trade along the 50 -verst border 
strip (1913) (Kireev 2009, 76-77). ${ }^{2}$ At the same time, Russia was establishing itself inside Manchuria: Russian peasants and Trans-Baikal Cossacks settled freely in Chinese territories near the border, and Russian villages and towns sprang up all along the Russian-controlled Chinese Eastern Railway (KBZhD). Imperial fantasies created the image of Zheltorossiya ('Yellow Russia') in celebration of the century of Russian control in this part of Asia.

With the victory of the Bolsheviks in the civil war, the situation changed. From the Chinese perspective, the presence of Soviet personnel inside China was contradictory: on the one hand, it was a source of economic, moral, and military support for the Communist Party of China; ${ }^{3}$ on the other, the preservation of the Tsarist borders and the Soviets' intrusive 'friendship' with Mongolia and Tuva were objectionable. Then the mass emigration of refugees from Soviet Russia into Northwest and Northeast China made the country the hostage of confrontations with these new 'enemies' of the USSR, manifest in the constant infringement of China's sovereignty by the Red Army and Soviet spies. The border zone became an area of the mass settlement of former Russian citizens, who differed sharply from other Chinese citizens because of their continued contact with the Russian and Japanese ${ }^{4}$ cultures. The popularity of Orthodox Christianity among the refugees, mixed marriages, and the proximity of Russia made this area an unusual zone of inter-civilizational contact, in which local Chinese communities came under intensive Russian, Mongolian, and Japanese influences.

In 1949, the USSR changed from being China's awkward neighbour into its cultural, financial, and technological donor. But this underlined Chinese fears about the priority of geopolitical interests over the ideology of internationalism among Soviet communists. After the denunciation of Stalin at the Soviet 20 th Party Congress in 1956, the relations between the two countries steadily worsened for various internal and external reasons, including the lack of understanding between Mao and Khrushchev. The nadir was the Cultural Revolution, when the USSR acquired the image of the northern hegemon threatening the territorial integrity of China (Tihvinskii 2008). The Chinese greatly reinforced the militarization of their border areas, which gave rise to the mythic idea ('mythologeme') of the 'frontier disloyalty' of the

2 It should be noted that these measures were not very effective, due to the weakness of the administrative apparatus and the fact that the Cossacks guarding the border had a direct economic interest in the presence of Chinese. Despite this, the measures were significant as the origin of a biopolitical repertoire of terms and practices that were again useful in the Soviet period.

3 This was not constant and was subject to political circumstances.

4 On the influence of the cultural policies and institutional organization of Japanese Manchuguo on the Chinese population, see Mitter (2000). 
Russian refugee settlers in China. This population was drawn into a complex emotional regime in the expectation of conflict, reinforced by limits on their movement and the general social-political sterilization of the region. Among the well-known operations are the persecution of the Russian and Buryat diasporas in China, the destruction of Russian architecture, and attempts to fully debar contact with the Soviet population over the border.

Between 1949 and 1986, the Soviet and Chinese policies of 'frontier socialism' broadly coincided. Mass migration from the middle of each country, together with the spread of primary education in socialist schools, had the effect of marginalizing the hybrid culture of the border regions and sharply accentuating the cultural distance between the Russian and Chinese sides of the border. The incoming populations began to dominate, bringing with them an absolutely different geographical imagination and gradually creating new forms of loyalty (Billé 2009; Peshkov 2014). The experience of the socialist border was in many ways transformed, not only concerning its present but also the understandings of its past. This brought a new ambivalence towards the neighbours on the other side: they are close, they have been living here, but we know almost nothing about them. When the border began to be opened after 1986 and the population of the area was allowed to become somewhat more mobile, people attempted to re-describe the former 'fortress regions' of the border in terms of openness, hybridity, and connections. However, this new period of Chinese-Russian cooperation brought radical changes in the balance of power between the two countries: it was no longer Russia playing the active role of donor and investor; instead, developing China actively tried to bring Russia's Siberian and Far Eastern regions into its orbit. Despite the significant potential gains from the demilitarization of the border, Russian society was not ready for such a sharp overturning of roles. As Franck Billé has written concerning the Russian semantics of the border:

A strong differentiator in the way Russians and Chinese currently visualize their common border is the emotional quality they attach to it. While for Chinese the north-eastern border with Russia appears to be seen, predominantly, as a frontier of opportunity where commercial ties can be created and valuable contracts concluded, in the Russian media the border is most often associated with illegal migration and criminality [...] and tends therefore to be perceived as a source of anxiety. (Billé 2012, 21)

This goes some way toward explaining the significant asymmetry in the emergence of Chinese spaces in Russia and Russian spaces in China. In Russia 
these 'Chinese spaces' consist exclusively of market sectors and restaurants, set up by Chinese with purely economic interests, while the wider semiotic space of Russian Far Eastern cities was sterilized of all traces of Chinese presence (see Introduction and Billé 2014) - for the first two decades of the opened border, it was impossible for Russians consciously to imagine any Chinese cultural traits being reproduced among its local citizens. ${ }^{5}$ But unlike in Russia, northeastern China was able to play freely with the Russian past of the region, making use of it as an element in a new local identity and as an attraction for investment. The general Chinese process of decentralization and the emphasis on cultural attractors for investment, especially for tourism, led to a situation in which the old Russian European-style buildings in Manchuria were re-valued positively by the market; now there is a demand not only for their preservation but also for the reproduction of the style as the cultural heritage of the region. This new situation is the opposite of the practice during the Cultural Revolution, when all signs of foreign presence were abhorred. Today traditional Chinese districts are replaced with new buildings without regret, but the remains of European presence are carefully preserved - and even re-created for the benefit of Chinese and overseas tourists.

One Chinese respondent from Three Rivers (a rural area settled by refugees from Soviet Russia) interviewed by the Russian researcher Ivan Basharov, explained the difference between the Russians on either side of the border. He described the Chinese Russians as follows: 'they are Russians but grown up on Chinese seeds' (Basharov 2010 305). If we remain with this interesting metaphor, we can ask what are the specifics of the Russian space that has grown up on Chinese seeds? Russian spaces in China are not a single, generally agreed-upon entity. They are, rather, a network of various object-spaces, linked only by the common theme of the revitalization of Russians' presence in a new economic situation. In the wider Chinese cultural field, these signs of Russianness mark the specificity of the region. The architecture of Harbin, the folk-Slavic fantasies of border towns, the urban architecture provided for ex-Siberian Evenki migrants, and buildings imitating churches in 'Russian' villages can all be seen as links in a chain. The effect has been to de-problematize Russia's role in regional history, while at the same time concocting new cultural models that are disconnected from the real past. In contradistinction with the previous 'Russian century', this process is directly linked to the current active position of

5 From 2015 the situation has started to change with the devaluation of the rouble and the consequent rise in popularity of Far Eastern and Siberian towns for Chinese tourists and shoppers. It is possible that the market will alter the cultural hierarchy on the frontier. 
China and its own interest in adapting the culture of its northern neighbour to its role in the Chinese cultural field.

In the case of Hulun Buir province in China, two types of Russian (Siberian) spaces can be clearly distinguished: trade towns and ethnic settlements. The two are distinguished by their temporal connotations: the trade town symbolizes friendship and cooperation in the present day, whereas the Russian peasant and Evenki ethnic settlements ${ }^{6}$ symbolize the trans-border past. It should be noted, though, that both the optimism about economic cooperation and the nostalgia for the 'lovely past' are subordinate to economics, i.e., the expectation of an inflow of shoppers and tourists.

\begin{tabular}{llll}
\hline Name & Type of space & Temporal orientation & Commercial aim \\
\hline Manzhouli & Trade town & Present and future & Trade, tourism \\
Enhe village & Russian village & Past peasantry & Ethno-tourism \\
Alaguya & Evenki settlement & Past forest people & Ethno-tourism \\
\hline
\end{tabular}

There are some common aspects of these spaces. First, they are 'spaces not for oneself' - they are fully subjected to the logic of the market, with priority given to the perspective of the trader, tourist, or investor (Bulag 2010). What we see is the absolutely artificial fabrication of authenticity to create commercially oriented images of the co-located past and the happy future. Symbolic objects are simply piled on top of one another, creating an effect of a-temporality and emptiness: hotels and bath-houses are built in the style of Orthodox churches, fields are filled with gigantic matryoshka dolls, and huge buildings represent Evenki chumy ('tepees'). Meanwhile, copies of Soviet heroic memorials collected into a single locale transform this 'Russian' (or 'Siberian') space into a non-place, one that has been created for a neoliberal reading of Russian presence as an instrument to heighten the attractiveness of the region for investment and tourism.

6 The re-settlement of Evenki reindeer herders into the special settlement of Alaguya (Chinese: Aoluguya; a suburb of Genhe in Inner Mongolia) is an interesting example of the re-Siberianization of the Tungus-Manchu peoples of China. This policy is directly connected to the reproduction of a Siberian heritage as a contribution to nation-building among these peoples. The supposed main aim of the re-settlement was the protection of the forests from hunter-nomads and the ending of nomadism as an outdated socio-economic practice. The village of Alaguya has a jumble of meanings as a space: a completely new settlement of contemporary family cottages is combined with official buildings in the style of 'Evenki architecture'. The consequence of the re-settlement was the division of the population into a majority (c. 190 people) living in Alaguya and a minority of around 30-40 people who tried to stay in the forests with a fairly large herd (c. 70o head) of reindeer (Fraser 2010). 
Paradoxically, these developments break the connection with the actual Russian past of the region. This is the consequence of two imperatives of the new trans-border orientation: first, the need to represent cultural multiplicity; and second, the requirement to accentuate the frontier loyalty of the local population. In this context, popular ethnography and official narratives about the loyal inhabitants are bracketed off and left virtually untouched. This helps to solve the dilemmas associated with a postcolonial perspective on the earlier Russian presence, and promotes a focus on the mutual enrichment of the two sides. Thus, without ceasing to be a narrative of the correct (political) choice to remain loyal to socialist China, ${ }^{7}$ the past can also become a reserve of positive symbols that are useful for attracting investment and tourism. If we add to this the influence of the ethno-tourism market on administrative decisions, then one could say that the past has become the hostage not only of the present but also of the economic expectations of the future.

\section{The urban space of trust: representations of friendship on the ruins of a border bastion}

Man'chzhuria was the first station on the strip of polosa otchuzhdenia (appropriated strip of land )of the Russian-built Chinese Eastern Railway, and for most of its history it was a small settlement for Russian and Chinese railways workers. It was more like a village than a town (Urbansky 2012). The main determinant of its role was the border, which lies on the northern edge of the town. Depending on the situation, Man'chzhuria/Manzhouli had various functions: it has been an advanced post for the Russian takeover of Manchuria, a Japanese border post, a place of lively trade between two brotherly socialist nations, an important centre for organizing Soviet help for China, and a Chinese fortress defending the area from the northern neighbour. A new epoch began on 16 April 1983, when, after sixteen years of isolation, trade between the border regions of the USSR (eastern Siberia and the Far East) and China (Heilongjiang and Inner Mongolia) restarted. Two years later, in August 1985, several pairs of towns along the border (Manzhouli-Zabaikal'sk, HeiheBlagoveshchensk, Suifenhe-Grodekovo, and Tongjiang-Nizhneleninskoe) were opened for border exchanges (Bazarov and Ganzhurov 2002, 59). From 1991, the former 'bastion' (i.e., fortified) towns along the border were turned into zones of formal and informal trade. This opening of the border was to determine the future of Manzhouli, which rapidly transformed from a poor, 
provincial settlement into the main hub for Sino-Russian economic relations (Zhang, Ma, Yu 2002). It became a contemporary commercial area that, while located in China, cited Soviet symbolism and architecture as it pleased.

This was an extraordinary form of Russification of urban space, which had the single aim of turning a border station into the most powerful trade and tourist centre of the region. Today Manzhouli presents itself as both a key transport hub (6o percent of Russian exports go through it) and an exemplar of a super-modern lifestyle. The quasi-East European architecture, the use of Russian on trade signs, and the inhabitants' almost fluent knowledge of Russian have turned the town into 'our China': maximally open to the Russian tourist or entrepreneur. The symbolic spaces of the town, from squares with matryoshki dolls to architectural images citing the Persian Gulf, play the role of 'Russia' for the Chinese and 'China' for the Russians, joining the two countries in a common post-socialist aesthetic and common economic interests. By bringing together contemporary architecture, Soviet symbols, and global signs (western brands, American food chains not found in Eastern Siberia, and Chinese goods adapted to Russian tastes), the town creates the atmosphere of an artificial place, at once alien and open to all.

Because of its remote location Manzhouli is not a global city, but it is the only regional example of an attempt to imitate such an idea. This has determined the city's external appearance, the nature of its new citizens, and its cultural politics oriented toward the common socialist past of the region. On the other hand, its border location gives it a local and seasonal character: in the summer, the city presents itself as a Chinese Russia to Chinese tourists, while for the rest of the year it is a Russian China for visitors from Russia. In this situation, we can see Manzhouli as the producer of trust in a minimum of three contexts: that of Russian tourists and traders, for whom it embodies the idea of cheap goods acquired in a comfortable atmosphere; that of Chinese tourists, who hope to trust that it stands for the real Russia; and that of the government, where it represents a city of intensive cross-border exchange.

All of these strategies are inter-connected. The recent (2015) fall-off in Russian visitors not only makes it difficult to sell Russian exotica but also threatens catastrophe, should the Chinese state become disillusioned about the 'city of friendship and trust'. The realization of such a disaster is rendered all the more probable by the peripheral locale of the nearby Siberian provinces, Russia's ever greater economic problems, and the advent of new logistical models for trade, such as the development of different transport links for industrial bases in the west of China (the Urumchi-Bishkek-Irkutsk line) and the rapid expansion of internet trade with China (see Ryzhova, this volume). The fate of the city is directly related to the integration of Chinese 
future-oriented economic perspectives (which now require a readjustment downwards) with the low purchasing power of a Siberian periphery that is greatly dependent on constantly decreasing subsidies from Moscow.

The creation of an urban 'space of trust and friendship' unites three imaginaries: the idea of the trade city, Chinese conceptions of the ideal Russian city, and the imitation of a global city. Unlike the infrastructure of memory (such as the Russian villages of Three Rivers, Trekhrech'ye) or the fabrication of authenticity oriented to the past but with a view to the future (Aloguya), this type of urban space symbolizes the future of the region as an important pole of cross-border development. Manzhouli is the epitome of the new Chinese urbanism. It joins the economy of expectation with an old practice typical of Maoist China: the city as the site of the materialization of utopia and the exemplar of new models of living ( $\mathrm{Lu}$ 2006). As Bulag wrote about the urbanization boom in Inner Mongolia:

Cities have emerged as the centers where industrial miracles and 'actions' occur, pointing towards a future utopia, departing from Mao's ideological ambivalence, and are represented in the media as an embodiment of modernity replete with much of the palette of global capitalist renderings of 'modernity' and its radically persuasive imagery of the good life, progress and development. (Bulag 2002, 212)

In the case of Manzhouli we are dealing with a complex form of urban spatiality, where ideas about 'good life, progress and development' are directly related to trans-border trade and the promotion of cultural links. And yet this urban space also links China and Russia in a multi-layered way that is in some ways akin to the Russian traditions of imperial urbanism in the early 2oth century. The centre of the city is a grid of six large parallel streets (avenues), with monumental buildings and geometrical crossing roads. This part of Manzhouli recalls Russian colonial practices during the construction of modernity along the Chinese Eastern Railway. Then, the aim was to replace the narrow and difficult-to-negotiate streets of the village-town of the frontier with the wide streets, large buildings, and business centres of the imperial town. The centre of Harbin is the ideal realization of this idea, and its reflections can also be seen in the centre of Chita and the older Russian part of Hailar. The ideal was a city entirely independent of local traditions, a city that had overcome the past and was oriented to the future. The irony of Manzhouli is that, while it is built in the monumental style of Russian/ Soviet architecture, the past that its neo-liberal future actually overcomes is not a Chinese one, but the early Russian model of the village-like settlement. 
In this context, the question of how the urban past should be represented has been determined by two basic lines of Chinese policy in the region: the reproduction of ersatz signs of Russian culture (the imperative of regional diversity), and the destruction of all real traces of the presence of Russians in the city (the imperative of the frontier loyalty of the local citizenry).

\section{Trust as a discursive choice: the semantics of the negative reputation of the city}

In 2010, Siberian newspapers and Internet portals publicized numerous cases of physical aggression in Manzhouli markets, which were then expanded on a mythic scale and linked to the idea of the 'awakened dragon'. The scale and context made the incidents something more than a mere description of the bad behaviour of a few sellers in a town known for its atmosphere of anonymity, quick money, and hedonistic 24-hour pleasures. Along with the Russian distrust of eastern traders, well described in the literature, one can see here the strange effect of another understanding: Manzhouli became the symbol of the town-as-market, which turned the 'town of trust and friendship' into a space of the deceit and aggression that has infected the whole trans-border space. A 40-year-old respondent in Irkutsk expressed his anxiety about awakening China as follows: Everyone says that Manzhouli is dangerous. Here, the Chinese have gone completely wild. In the market they do exactly as they want. They can hit you if you don't buy'. Internet forms depict Manzhouli as a danger, not only for Siberia but also for the whole of China. Thus a forum participant with the nickname Irina wrote: 'And in fact, such criminal rubbish could only arise in Manchzhuria. The place is a "black hole". And it will spread onwards in China, like in the good old days. We must hope that the Manchzhurian infection does not take over the whole of China.'

What is the reason for such distrust of the 'town of friendship and cooperation'? It can be argued that it is indeed the spatial aspects of the border trade town that gives rise to such unexpected emotional reactions. First, penetrating the ambivalent zone of the border activates Russian ideas of the 'Asiatic frontier' as a space of danger and unwelcome encounters. As will be shown, we must not underestimate the ability of such ideas to drive a wedge between experience and representation. The second barrier is the concept of the 'Asiatic market of Chinese type', which is directly linked

8 Manchzhuria.ru-gorod glazami turistov. http://www.manchzhuriya.ru/viewtopic. php? $\mathrm{f}=22 \& \mathrm{t}=86$. 
to negative stereotypes about Chinese traders and the hidden threat of economic domination. The third aspect, no less important, is the town's role as a showcase, which simultaneously offends at least three Russian assumptions: about the proper vector of modernity in the region (themselves), about the very possibility of the town-cum-market, and about the prospect of collaborative development with China. These assumptions to a great extent determine the meanings given to the urban space and the resulting doubts about whether this city can provide the conditions for profitable exchange.

A good illustration of the divide between actuality and its representation is the contrast between the daily experience of visitors and the image they create of the dangerous, unwelcoming city. All respondents underlined the potential perils of being in Manzhouli, an idea applied both to nighttime streets (theft and mugging) and to daytime market places (cheating, aggressive sellers). Some cases of trickery and other crimes do of course take place, but to call Manzhouli a city dangerous for everyday life is an extraordinary exaggeration. In fact, this grim assessment of Manzhouli was contradicted by the behaviour of the visitors themselves. Until early 2015, all of the restaurants and nightclubs were filled with contented people freely taking advantage of the anonymity of the border town to participate in parties and sexual encounters. Chinese and Russians often enjoyed the same places, occasionally in one another's company. But recollections of this experience in interviews, the press, and Internet forums were surprisingly anxious, gloomy, and alarmist. Pervasive dangers and cases of deception were constantly invoked. Describing the Asiatic trade town as a place of falsity, hypocrisy, and aggression, the respondents painted themselves as heroes who stood up to serious ordeals. This alternative memory not only masks the real experience, but also reproduces a mythic image (mythologeme) that is important in Russian culture: that of the Asiatic frontier as a place of meeting with danger and the unknown. ${ }^{9}$ We can argue that this mythic

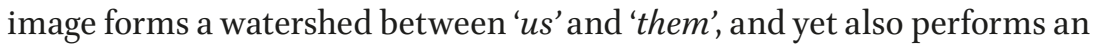
integrative function. By creating an imagined community of normal people in an abnormal place (the border), it folds the Russian notion of border capitalism into a process of symbolic reproduction of the border as a protective bastion. In this vision, tourists coming to buy fur coats, Dagestanis running an underground casino in Chita, the manager of a brothel in Irkutsk coming to buy underwear for her sex-workers, the hospital administrator from

9 Similarly, the collective memory of the Soviet contingent in socialist Mongolia fixed on a fictive political confrontation with the local population of Russian refugees from Communism, driving out actual memories of their work or military service (Peshkov 2012). 
Ulan-Ude purchasing goods for the shop in his home village, shuttle-traders from nearby hamlets, artists from Donetsk, and former prisoners and former soldiers from Trans-Baikalia - all of these individuals and groups suddenly become some social whole that is threatened by Chinese aggression.

This distrust creatively unites the Russian colonial tradition of demonizing Chinese traders with the experience of the small market business in Siberia. The old Tsarist-era stereotype of the cunning, cheating Chinese took new forms after 1991: the former workers in socialist factories turned into tenacious Asiatic traders, who were seen as isolated from society, not understandable, and potentially threatening. The discourse of 'a civilizational gulf' and journalistic 'culture-ology' made it impossible for people to see any relationship between the socio-economic regress of the East Siberian border region and the long practice of drawing in labour power from China, a situation with many causes including the collapse of the system of organization on the frontier (demilitarization), the end of collective agriculture, and the hesitant adaptation of old industries to the new conditions (Ericson 2000; Hassard et al. 2007). Unlike former Soviet ethnic groups such as the Kyrgyz (see Introduction), the Chinese were understood in the context of a geopolitical mission specific to them, in which their good qualities (capacity for hard work, discipline, and modest way of life) became not only signs of their dangerously greedy economic expansionism but also an excuse for de-humanizing them. Thus, Tobias Holzlehner writes about the demonization of the Chinese in the first two decades of reform:

Patriotic discourse predominates in the press. The Chinese are presented as an amorphic mass like a moving swarm ready to engulf their helpless hosts and they are compared metaphorically to restless locusts or cockroaches [....] Added to this there is the image of rapacious Chinese as dangerous bodies, capable of spreading infectious diseases among the Russian population. $(2009,108)$

These ideas, when combined with the subjective extraterritoriality of the city, are related in a complex way with the negative image of the Chinese in Manzhouli: the two add to one another and create a false, seemingly empirical justification for xenophobic attitudes toward the neighbours.

As a city-market, Manzhouli is a challenge for the Russian post-Soviet periphery, since it rubs against both a cultural hierarchy (West superior to East) and an economic asymmetry (China strong, Siberia weak). People accustomed to contrasting Western and Soviet forms of modernity cannot accept the non-Soviet socialist modernity of China (Peshkov 2010). The 
presence of a super-modern city on the other side of the border is seen not as a success of China, but as an abnormal humiliation of Russia. Manzhouli manifests everything new, which is perceived by the Russians as an outrageous slap in the face in the context of the failure of economic reforms in Russia - namely, the daring of Asiatic entrepreneurs, the plenitude of goods in China, and the success of only one side in joint ventures. The inability of Trans-Baikaliya to benefit is understood to be the result of the unpractical nature of Russians and the economic pragmatism of the Chinese. Lena, an inhabitant of a border village, expressed her suspicion (which in my view is typical) about the success of Manzhouli: 'They have built everything on our money. I remember when Manzhouli was a village worse than Zabaikal'sk, but now... It's necessary to be careful with them [the Chinese].'

Russian ideas about the peripherality of the entire region add to this picture, despite the efforts of the citizens and municipal officials. Manzhouli is seen as a phantom that only imitates modernity, appearing artificially in a region that is inherently incapable of real progress. The majority of my respondents, especially those from Eastern Trans-Baikalia, saw Manzhouli as a continuation of the geographical captivity determined by their region's provincial status in relation to the Russian metropolises (Moscow, St. Petersburg) and other global cities. The Russian mental geography unequivocally posits the vectors of culture and development as moving from West to East. In this perspective, the border region is seen as a 'zone of depression', distant even from Siberian cultural centres. Anyone going to live in Manzhouli is ranked among the lowly, non-prestigious class of small traders. Respondents did not recognize any non-utilitarian reasons for being in the town, and tended to explain the presence of chance visitors (from central Russia, Eastern Europe, or the Baltics) as an almost incredible jump into the depths of remoteness. Sergei, a driver from Petrovsk-Zabaikal'sk, expressed this attitude when he commented to me, 'So everything can't be alright for you, can it, if you've ended up here?' In this perspective, Trans-Baikalia is seen as a space of new poverty while Manzhouli appears as a bezkul'turnyi ('cultureless') town-market, and both are similarly locked into the geographical captivity of remoteness.

Mistrust in the city as market has deeper roots, deriving from the fact that including both ideas in one space is alien to Russian urban culture. The latter has always subordinated the market to the city, dividing it off as a separate, fenced-off place or externalizing it outside the town (Humphrey and Skvirskaya 2009). In her paper on trade, 'disorder', and citizenship regimes, Caroline Humphrey relates this attitude toward trade and traders 
to Russian ideas about disorder (2010)..$^{10}$ The two decades after the material for that paper was gathered have not changed these cardinal Russian ideas. The Orientalist imaginary of the disorder of Asiatic trade jells with most Russians' perception of both internal (ethnic market places) and external (Asiatic trade zones) business towns as places of deceit and light money. Elena Trubina, analysing the relation between classical views on the city and contemporary Russian urbanism, also remarks on the absolutely negative opinion toward the bazaar:

Among us the bazaar is associated with eastern savagery, immigrant traders, and 'non-organised' trade. The problematic unanimity with which ordinary people, intellectuals and political leaders have recourse to such metaphorical associations is expressed in many judgments and putdowns. For example, inhabitants of a St Petersburg suburb complained to journalists about the dreadful outburst of street trading in cheap goods, carried out by 'immigrants from southern republics, mostly probably here illegally'. The complainants do not hesitate to accuse the incomers of recent thefts in the suburb and even claim that they are the cause of the 'anti-social behaviour' (bytovoi extremizm) of the local inhabitants. [...] The 'bazaar' as a metaphor of plentiful opportunities and attractive variety has transposed into an emblem of the alien and the extraneous, which is felt to lie in wait for all those who do not 'patriotically' care about the boundaries of their community. (Trubina 2010)

From this perspective, disorder can be seen as the essence of the city-asmarket, irrespective of its external appearance; it is immanent in such a place, and in many ways is its derivative. It is this fear of a lack of order that turns anxiety into a fundamental mistrust of the city-cum-market as the alter ego of the good post-Soviet city.

\section{Testing friendship: problems of trust and attempts to resolve them}

Let us turn to the techniques of cheating in the city. The trap of mistrust was a problem for the city from the moment it became a trading town. In fact, the Chinese aim of creating a new 'idea' of the city was to overcome this problem of distrust. The newly devised symbolic field, the use

10 Disorder is most commonly associated with the site of markets and the places where boundaries cross one another (Humphrey 2010, 113). 
of Russian, and the provision for payment in roubles, were all intended to create comfortable conditions for business and leisure. Yet, as I have described, trust is the last thing that comes to the mind of visitors from Russia. Practically everything makes them nervous: the sleepless town blazing with neon lights contrasted with the darkling ruins of Soviet TransBaikalia; the quantity and quality of the goods; the Chinese production standards that are different from Russian ones; the dubious authenticity of Chinese prices; the insincere geniality of the Chinese salespeople (or its opposite, their sincere anger); the incomprehensible Chinese vodka that masquerades as Russian; the spicy Chinese food; and even the unfamiliar bodies of Chinese prostitutes. ${ }^{11}$

Most of these worries are typical of other post-socialist trading areas or cheap Asiatic resorts. In the former, the absence of procedures, common standards, and controls gives rise to very low prices but at the same time goods of dubious quality. In the latter, Asian countries' laxity with regard to foreigners (allowing informal currency exchange, open prostitution, and easy border entry) makes a stay more convenient, but also creates an opening for swindlers and criminals. In this respect, many problems of distrust have a rational basis: the confusing differences in the sizes of clothing and footwear produced by Chinese factories under one brand name, linguistic misunderstandings, the energetic Chinese style of salestalk that gives the impression they want to sell at any price, and so forth. The deceptive similarity of Manzhouli to a Siberian town (Russian signage, Russian music in bars, etc.) is also disturbing, given the differences already alluded to. The net effect is to give an impression of generalised low quality, which is not compensated for by the low prices. The over-hasty enthusiasm of some Chinese service agents has also played a role, since they would take any job without having the necessary credentials. However, much of the so-called obman ('trickery') was really something else: a lack of understanding, different emotional tone in selling, or an attempt to keep hold of a client at any price - though of course there were also occasional extravagant attempts to cheat 'rich' Russians. But the main objective basis for the mistrust must lie with the subjectivity of the visitors. It lies in the fact that Russian business people have to balance the fear of loss and the hope of gain in an arena that provokes feelings of danger and alarm. The fear of losing makes them search out 'our Chinese' (known local agents),

11 There is a rather popular story that in Manzhouli under-aged prostitutes are 'slipped in', after which the police are called. The absence of any cases of foreigners being prosecuted for sex with under-age girls has not stopped the spread of this rumour. 
but the hope of making a profit creates the mistrustful suspicion that even 'our Chinese' are not offering the best (lowest) prices. This gives rise to an insoluble contradiction between the attempt to resolve problems through 'known Chinese' and the search for 'real Chinese prices' that have been 'hidden from Russian entrepreneurs' by their new Chinese friends - i.e., there is a mistrust in one's own ability to organize access to economic bargains. The strategies arising from these fears have the effect of pushing Chinese sellers - who know that the Russians are going to be dissatisfied in any case - to sell their goods in any way possible. We could therefore suggest that it is not the problems faced by the Russian guests that are unique, but their means of reading them. Universal difficulties of border trade are formulated into a vocabulary of distrust toward the people, the town, and the border location itself.

Both Chinese and Russians agree that dishonest trade and aggressive behaviour can be found in Manzhouli, but they explain this with different causes and absolutely different perspectives. For the Chinese, the cases of cheating are correctable and temporary consequences of the fact that a huge number of diverse people have marvellous opportunities to make money. For them, the priority given to development over security and the consequent toleration of a certain grey zone underpins the image of the 'town of success' that goes along with neoliberal hopes of prosperity. This is why Manzhouli was for a long time taken by the Chinese to be the very symbol of the right (successful) model of cooperation. The size of the problem of trickery was also considered to be very different. For the Chinese, it was a matter of a few traders and a consequence of the ignorance (or naivety) of Russians, who should have taken care to distinguish the few bad Chinese from the majority of normal ones. The general Chinese understanding of the need for trust resulted in action: large numbers quickly took up the profession of the 'Chinese friend', the pomogai ('helper') who would resolve problems on the spot. Inner Mongols and Shenehen Buriats also became guides for Russians, and their culture is considerably closer to that of the Trans-Baikal/ Siberian folk from over the border. They value this status highly and use it responsibly. There are few critical comments about them from Russian citizens, and they are not thought to pose any danger. ${ }^{12}$ The Chinese state's

12 One of my Inner Mongolian respondents, Chinggis, remarked that Russians do not notice the drama of Inner Mongols from mixed families. 'I am a Mongol with a Chinese face. It's complicated. It is a good thing that the Russians are unaware of my Chinese parent.' Consciously or unconsciously, Chinggis distinguished himself from Chinese pomogai ('helpers'): he was more reserved, correct and calm, which his Russian clients saw as positive traits and attributed to the fact that he was not Chinese. 
response to the need for trust creation was to set up a network of telephone numbers to call in case of complaints, make sure that Russian-speakers man the lines, and issue pamphlets with advice about security for visitors.

Nevertheless, these measures have not solved the problems of mistrust and they are also widely ignored by the Russians. The balance of dishonest versus honest traders is understood completely differently by the Russians, since they attribute some degree of hypocrisy to all Chinese. While noting the presence of good Chinese - a trait that is based on befriending Russians or just generally being decent people by nature - every one of my Russian respondents nevertheless commented on the generally rapacious character of the Chinese entrepreneur. Each case of trouble was taken as proof of this negative viewpoint, and isolated examples of trickery were seen as the norm in the Chinese market. It is significant that the fact that a very large number of Russian small traders have been able to make good money themselves (see Namsaraeva, this volume) was hardly ever mentioned, and was indeed barely noticeable against the flood of negative comments. This harsh attitude is linked not only to the factors already mentioned (the traditional view of the Asiatic market city as a place of fraud and profiteering), but also to the general priority given by the Russian state to security over economic development. The understanding was that there could be only two solutions to the problem of distrust: first, to work with 'good Chinese', i.e., entrepreneurs with irreproachable reputations; and second, for Russian mediators to emerge. In both cases, we can see that each 'solution' only increased the problem on a new level. The idea that there is a small group of 'good Chinese' only emphasized the hostile and suspect character of the rest. And in fact, when Russian mediator firms - which stood to lose out to Chinese competitors - did appear, they used their strong links with the media to discredit their Chinese counterparts as a way of protecting their own small segment of the market.

This last example shows the importance of reputation (which is directly linked to trust) in an antagonistic cultural area. Good reputations enable the participants in an exchange to decrease both their informational costs and the risk of receiving low quality goods or inappropriate prices. But, as we have seen, creating such a reputation in a situation of general mistrust requires the construction of the category of the good Chinese; this allows visitors to Manzhouli to do business without giving up their wider anxieties about the city. This is a trap that paradoxically only strengthens their fears. From this point of view, the problem of mistrust is insoluble, since each new decision gives rise to a new spurt of distrust. This combination of suspicions about the city and the city-as-market with an aggressive search for the 
lowest possible prices has led to a spiral of disappointment and mistrust. Spatial projects and a fear of Chinese greed have turned out to be stronger than the idea of a cross-border machine of economic growth in the region.

\section{Conclusion}

China is carrying out a model of reform that preserves the characteristics of 'transitional society' into an indefinite future (Naughton 2007), and consequently many of the social responsibilities of the state are being gradually shifted to the individual sphere (Bhalla and Qiu 2009. This creates the conditions for a hybrid development of the border territories, where the goal of state policy is not only the modernization of industry and infrastructure but also the orientation of the border zone toward trading with the Russian and Mongolian markets. The problem with this model is that it is based on expectations of the future while being tied to fluctuations in the economies of the neighbouring countries. The fall of the rouble, the reduction of Russian state subsidies, and the general lack of certainty about tomorrow in Eastern Siberia have turned out to be more dangerous for Manzhouli than for the Siberian regions themselves. Actors in the market predict a downturn until at least 2018, and say this will inevitably lead to the temporary or permanent extinction of the energetic life of the city. But the inability of Manzhouli to realize its own slogan of trust and friendship is also playing a role in its downfall. Manzhouli was declared a place of deceit and aggression long before the most recent Russian economic problems. Besides the objective reasons (i.e., the problems of carrying out trade in subjectively 'extra-territorial' conditions), this negative attitude rests on three images that Russian clients find objectionable: the showcasing of Chinese success on the immediate other side of the border; the city-asmarket; and the one-sided creation of a border development zone. Despite the (in fact rather positive) experience of contact, the image of a town of friendship and trust has been submerged in the complex process of the adaptation of Russians to the end of the 'Russian century' in this part of Asia.

This chapter has shown that the Russian reaction to a convenient place for trade and leisure was significantly influenced by subjective factors related to the experience of Russian colonial policies: most notably, the legacy of the Soviet culture of fear and emotionality associated with border territories and the Russian refusal to accept visible Chinese success on land that had earlier been Russian territory. These factors lie behind the radical confrontation of trust and mistrust created by the border, and the idea of a 
border trade hub that would have been useful to everyone was subordinated to the discourse of danger arising from Russian fear of the economic might of China. The conceptual marginalization of Manzhouli by many Russians is a result of the present consensus that gives priority to post-soviet anxieties about security rather than the creation of a joint economic success story in the region. We can suggest that any successful attempt to create trust in the future will depend on a re-thinking of three current mythologemes of post-Soviet consciousness: the spatial (the periphery is dependent on the centre), the border (the need for protection from Chinese invasiveness), and the economic (the impossibility of cooperation without making a loss).

\section{References}

Basharov I., 2010. Russkie Vnutrennei Mongolii: kratkaia harakteristika gruppy [The Russians of Inner Mongolia: A Short History of the Group]. In Boris Bazarov (ed.), Asiatskaia Rossiia: migratsii, region i regionalism v istoricheskoi dinamike [Asian Russia: Migrations, the Region and Regionalism in Historical Dynamics]. Irkutsk: Ottisk, pp. 301-308.

Bazarov, B.V. and D.P. Ganzhurov, 2002. Rossisko-kitaiskie otnoshenia irol' regionov $v$ vostochnoi sibiriv ich razvitii [Russian-Chinese Relations and the Role of Eastern Siberian Regions in Their Development]. Irkutsk: Ottisk.

Bhalla, A.S. and Shufang Qiu, 2009. Poverty and inequality among Chinese Minorities. London and New York:Routledge

Billé, F., 20og. Cooking the Mongol/feeding the Han: Dietary and Ethnic Intersections in Inner Mongolia. Inner Asia, 11(2), pp. 205-230.

Billé, F., 2012. On ideas of the border in the Russian and Chinese social imaginaries. In Franck Billé, Gregory Delaplace, and Caroline Humphrey (eds.), Frontier Encounters: Knowledge and Practices at the Russian, Chinese and Mongolian Border. Cambridge: Open Book Publisher.

Billé, F., 2014. Territorial phantom pains (and other cartographic anxieties). Environment and Planning D: Society and Space, 31, pp. 163-178.

Bulag, U.E., 2002. From Yeke-juu league to Ordos municipality: settler colonialism and alter/native urbanization in Inner Mongolia. Provincial China, 7(2), pp. 196-234.

Bulag, U.E., 2010. Seeing Like a Minority: Political Tourism and the Struggle for Recognition in China. Journal of Current Chinese Affairs, 41(4), pp. 133-158.

Cook, K. (ed.), 2001. Trust in Society. New York: Russell Sage Foundation.

Duafang Lu, 2006. Remaking Chinese Urban Form: Modernity, Scarcity and Space, 1949-2005. London and New York: Routledge. 
Ericson, R.E., 2000. The Post-Soviet Russian Economic System: An IndustrialFeudalism? BOFIT Online, 8. https://helda.helsinki.fi/bof/handle/123456789/12665 (access date 15.01.2016)

Fraser, R.F., 2010. Forced relocation amongst the Reindeer-Evenki of Inner Mongolia. Inner Asia, 12(2), pp. 317-346.

Hassard, J., J. Sheehan, M. Zhou, J. Terpstra-Tong, and J. Morris, 2007. China's state Enterprise reform: From Marx to market. London: Routledge.

Holquist, P., 2001. To Count, to Extract, and to Exterminate: Population Statistics and Population Politics in Late Imperial and Soviet Russia. In Ronald Grigor Suny and Terry Martin (eds.), A State of Nations: Empire and Nation-making in the Age of Lenin and Stalin. Oxford: Oxford University Press, pp. 111-144.

Holzlehner, T., 2009. Vostochnaja poristost': antropologija transgranichnoj torgovli i kontaktov na rossijskom Dal'nem Vostoke [Eastern Porosity: Anthropology of Transborder Commerce and Contacts in the Russian Far East]. Oikumena, 3, pp. 102-111.

Humphrey, C. and V. Skvirskaya, 2009. Trading Place: post-soviet container market and the city. Focaal: European Journal of Anthropology, 55, pp. 61-73.

Humphrey, C., 2010. Postsovetskiie transformatsii v asiatskoi chasti Rossii [PostSoviet Transformations in the Asian Part of Russia]. Moscow: Natalis Press.

Kireev, A., 2009. Spesyfika dalnevostochnoi granicy Rossii: teoria i istoria [The Specificity of the Russian Far Eastern Border: Theory and History]. Oikumena, 2, pp. 70-82.

Mierzejewski, D., 2012. Reading Years of Humiliation. Sino-Russian Border and China's National Identity. Sensus Historiae, 8(3), pp. 59-70.

Mitter, R., 2000. The Manchurian Myth:Nationalism, Resistance, and Collaboration in Modern China. University of California Press.

Naughton, B., 2007. The Chinese economy. Transition and Growth. Cambridge, MA: MIT Press.

Peshkov, I., 2010. Granica na zamke postsovetskoj pamiati. Mifologizaciia frontirnykh soobshhestv na primere russkih iz Trekhrech'ia [The Border Under Lock and Key of Post-Soviet Memory. The Mythologization of Frontier Communities Based on the Example of the Three-River Delta Russians]. In V. Dyatlov (ed.), Migracji i diaspory v sociokul'turnom, politicheskom i ekonomicheskom prostranstve Sibiri. Rubezhi XIX-XX i XX-XXI vekov [Migrations and Diasporas in the Social, Cultural, Political, and Economic Space of Siberia]. Irkutsk: Ottisk. Peshkov, I., 2012. Politization of Quasi-Indigenousness on the Russo-Chinese Frontier. In Franck Billé, Gregory Delaplace, and Caroline Humphrey (eds.), Frontier Encounters: Knowledge and Practices at the Russian, Chinese and Mongolian Border. Cambridge: Open Book Publisher, pp. 165-183. 
Peshkov, I., 2014. Usable Past for a Transbaikalian Borderline Town: 'Disarmament' of Memory and Geographical Imagination in Priargunsk. Inner Asia, 16, pp. 95-115. Tihvinskij, S.L., 2008. Vosprijatiev Kitae obraza Rosii [The Chinese Perception of the Image of Russia]. Moskva: Nauka.

Trubina, E., 2010. Dzhungli, bazaar, organism i mashina: klassicheskie metafory goroda i rossiskaia sovremennost' [Jungle, Bazaar, Body and Machine: The Classic Metaphors of the City and the Russian Contemporary Times]. Neprikosnovennyizapas, 2(70). http://magazines.russ.ru/nz/2010/2/tr2o.html.

Urbansky, S., 2012. A Very Orderly Friendship: The Sino-Soviet Border under the Alliance Regime, 1950-196o. Eurasia Border Review, 3 (Special Issue), pp. 35-53. Zalejko, G., 1994. Soviet Historiography as 'Normal Science'. In Jerzy Topolski (ed.), Historiography between Modernism and Postmodernism: Contributions to the Methodology of the Historical Research. Amsterdam and Atlanta, GA: Rodopi. Zhang Ping-Yu, Ma Yan-ji, Yu and Zhen-han, 2002. Border port Manzhouli: Urban Function and Space Development. Chinese Geographical Science, 12(4), pp.315-320. 


\title{
Différances of Doverie
}

\author{
(Mis)trust and the Old Faith in the Russian Far East
}

\section{Dominic Martin}

Humphrey, Caroline (ed.), Trust and Mistrust in the Economies of the China-Russia Borderlands. Amsterdam: Amsterdam University Press, 2018

DOI: $10.5117 / 9789089649829 /$ MART

\begin{abstract}
This chapter interrogates a putative link between trust and faith through an ethnographic description of post-Soviet Old Belief, a tradition of dissenter Russian Orthodox Christianity, in the cities of the Russian Far East. A return to the origin of the word in order to 'catch sight of' the phenomenon to which it points leads to the conclusion that trust (do-verie) is something 'until' or 'before' faith. Two very different congregations make up this community, and the word doverie means different things to these different groups. Rather than some stuff ('trust') that is lacking between them, each community seems disposed to grasp different sorts of relationships as trustworthy or not, reflecting their dissimilar and indeed conflicting perspectives on the last years of the Soviet Union, the collapse of socialism, the market, and economic ethics as they made their ways towards faith.
\end{abstract}

Keywords: Russian Orthodoxy, post-Soviet, phenomenology, spiritual division of labour, catholicity (sobornost), Protestant ethic, capitalism

\section{Introduction}

According to political scientists, the level of trust in Russia today is low compared to Western countries. In response to the Levada Center's question about which statement best describes their level of doverie ('social trust'), 75-80 percent of respondents stated that 'one must not trust people, but rather it is necessary to be careful with them.'. Such surveys suggest 
that nedoverie ('lack of trust') might explain why a Western-style market economy and 'civil society' have failed to take root in post-Soviet Russia. The lop-sided shape of these responses suggests the inverse of another survey question, to which the same percentage of Russians reputedly reply in the affirmative: 'Do you have trust (doverie) in President Putin?' Statistically, then, 'trust/mistrust' can be framed as the factor that both underlies the absence of democratic rule in Russia, as well as the failure of markets to function smoothly there.

There might be a problem, however, with this formulation of trust-doverie as lacking in one sphere and abundant in another: it suggests that the 'trust' in which President Putin is putatively held and that the 'trust' that is lacking in one's consociates refers to the same thing. But does this 'trust' in the President and for one's neighbours refer to the same objectively measurable stuff? There may be another way of framing this problem that does not treat trust-doverie as some kind of solid, weighty stuff when present, and as a lack or a void when absent. This approach would be to take 'trust' as a disposition that holds people and groups in tandem or in tension: as an attunement that, although often veiled, nonetheless exercises an omnipresent effect - and not always the effect of consensus that one usually ascribes to 'trust'. Could there not be several modes of trust that might clash, compete, or exclude each other, so that, for example, a certain kind of trusting attitude toward the President might exclude the capacity to build a consensus or to engage in equitable economic exchanges with fellow citizens? This complexity would be doubly true if trust were a relational phenomenon that depended on something else. If both of these features were the case, then people's ability to verbalize their trusting attitudes in response to an opinion poll might be an untrustworthy method of gauging 'trust'.

There is indeed a very simple reason to suspect that, on the one hand, 'trust' might stay in the background and out of discursive elaboration if and when it works, and on the other, that it is relationally constituted. These two facets of trust - that it precedes, anticipates or delimits a threshold, and that it relates to and depends on something else (and so, taken together, forms the negative condition that grounds a positive possibility) - are suggested by the word itself. The phenomenon that trust touches upon and circumscribes, if we take the simple, formal indication of the word seriously, is faith. The Russian word for trust is doverie, which parsed literally means do- ('before or until') vera ('faith'). The word itself, while not a panacea for our theoretical problem, might provide a clue as to how the different dispositions of trust might be contrastingly structured: 
What counts, rather for us in reliance on the early meaning of the word and its changes, is to 'catch sight of' the realm pertaining to the matter in question into which the word speaks. What counts is to ponder that essential realm as the one in which the matter named through the word moves. (Heidegger 1977, 159)

Some Russian native speakers have told me that, when one considers its original meaning, doverie does indeed carry the connotations of anteriority that are implied by the prefix $d o$-. In this context, unpacking some implications of the combinations and condensations of doverie might be a worthwhile exercise.

The archaeological excavation of language can help the anthropologist if it brings into view an under-investigated aspect of ethnographic reality and provokes such questions as: How do trust and faith relate in ordinary Russian life? Must one co-exist with the other, or do they sometimes interfere with each other? When trust is present is faith in the background, and when faith is foregrounded is trust taken for granted? When faith is explicit do the clashing trajectories of trust reveal themselves, which otherwise would be silently working behind the scenes? If the phenomenon of trust is essentially hard 'to catch sight of', then we might be aided in our search by focusing on somewhere faith is brought into the strongest relief and on someone for whom faith is a way of life. Do such people trust each other, and does trust underpin or undermine their faith or do they operate with different modalities of trust? What supervening political and economic conditions and orientations shape communities' ability to trust? Such an ethnographic starting point requires us to treat trust not as some universal, objective cross-cultural binding material that can be infused into a social system for its lubrication (economic or otherwise), but instead allow us to discover the undetermined multiplicity of trust.

This chapter will interrogate this putative link between trust and faith through a description of post-Soviet Old Belief, a tradition of dissenter Russian Orthodox Christianity, in the cities of the Russian Far East (Primorskii Kray). By means of this ethnographic example, it will be seen how doverie, the Russian word that is usually (mis)translated as the (theologically loaded) equivalent of 'trust', points towards a non-representable other, outside of faith. It signifies the zero level and turning point at which faith begins for at least one group of Old Believers. Doverie thereby forms the negative possibility of this transformation, and is therefore not quite a religious phenomenon but a para-religious one, which subsists in that netherworld where religion and politics are as yet undifferentiated. Two modalities of 
trust and its relationship to faith will be shown functioning within the same formal organization: the Far Eastern Diocese of the Old Believer Church. ${ }^{2}$ Old Believers, zealots who broke from the Russian Orthodox Church in the mid-seventeenth century when Patriarch Nikon and Tsar Alexei Mikhailovich enforced changes in the Church's rites, and who for three centuries have maintained a stance of staunch resistance to both State and Church as a way to preserve the Old Faith, are a byword in Russia for a group that binds trust and faith together. Some observers have even seen in the Old Believers an exemplification of an autochthonous 'Russian Protestant ethic' and a corresponding potential for economic development on the model of the Weberian thesis. It might therefore be illuminating to see how doverie works in one post-Soviet revival of this tradition. To borrow Alexander Gershenkron's (1970) metaphor, the Old Believers provide us with the 'Russian mirror' in which to reflect Western economic and political theory's unthought assumptions on the nature of trust.

\section{Dizzying Doverie}

Before entering the ethnography, however, it first necessary to pause on the nature of this word, doverie, so as to try to 'catch sight of' the different modes through which it arises in the subsequent description. For the purposes of this analysis, the word will be broken down into its component parts: the prefix $d o$ - and the stem vera. On first examination, trust's connection with faith, which is spelled out in the word 'doverie' itself, is hard to pin down. The stem is unambiguously the Slavonic translation of the Biblical Greek word for faith, pistis. The prefix, however, is polysemic and can be translated in a variety of ways, depending on what syntactical value one gives to the prefix once the word has been parsed into its morphological components.

$D o$ is a polysemic particle in Russian that has two subtle but quite different syntactical inflections. Firstly, do is an adverbial modifier that can mean 'before', in the sense of 'previous to', as in the antithesis to 'after' (posle); in its adverbial form, do provides an answer to the question 'When?' (kogda?). But secondly, do is also a preposition that indicates 'until', 'till', and 'up to', with the antithesis 'since then', 'from then on' (s); in its prepositional form, do answers the question 'until which point/stage/time?' (do takikh por/do kakoe stepeni/kakogo vremeni?) or, more simply, the English

2 These Old Believers belonged to the priestly tradition of the 'Belokrinitskaya Hierarchy', which retains the Orthodox episcopate. See Rogers (2009). 
'How long?'. Prepositional do-'until' inscribes the temporal and spatial limit of an action. Unlike adverbial prefix do-'before', which merely posits an indefinite and imperfect earlier time, do-'until' pinpoints a change, a cleavage: a conversion. Do-'until' indicates an end (a goal), which necessarily implies a beginning: a (re-)birth.

However one interprets the prefix do- (an ambiguity that will hopefully give an interpretive key in the coming ethnography), such a morphology hints at a phenomenon that lives outside of and is anterior to faith. But while the semantics indicate something at the spatial and temporal threshold of faith, from the etymological point of view the word suggests the opposite. It does not imply that trust is before, prior to, or until faith. Instead, it seems as if an ancient stem has subsequently had one of a variety of prefixes attached to it (do-, pro-, u-), which suggests that first came the stem - vera - and then came its derivatives: do-verit' ('to trust'), pro-verit' ('to check'), u-verit' ('to convince'). This decomposition intimates that vera ('faith') came first, and then do-verie ('trust'): faith before trust, not vice versa.

The perplexity particular to the Russian language appears clearly in Emile Benveniste's famous etymological excavation of trust. The great French historical linguist first tracked the Indo-European notions of faith and trust back to their common root, '*kred' (from which Latin credo derives). This archaeology led him to posit credence-trust as the predecessor to credo-faith: he wrote that '[f]rom the beginning of the tradition the notion of "credence" (créance) expands into "faith" (croyance)' (Benveniste 1969, 171). ${ }^{3}$ Yet, when one reads Benveniste's analysis in Russian translation something strikes the reader as jarring: ${ }^{4}$ the statement that doverie 'expands/enlarges' into vera (ibid.). But how can a stem with a prefix (doverie) 'expand' into the stem (vera) itself? A glance at the words convinces us that, in Russian, the opposite is the case. This aporia between morphological semantics (do-verie as 'trust before or until faith') and etymology (first stem, then prefix + stem), by which the priority and anteriority of one term is collapsed and condensed into the other, might not be just some linguistic trompe l'oeil but may instead point towards something about the nature of 'trust'.

Switching the focus from the prefix back to the stem, we are spun in yet more circles. Vera ('faith') is the translation of the New Testament pistis, a word the Russians received from Cyril and Methodius, the Tenth Century

3 The French reads "La notion de "créance" se trouve élargie dès le commencement de la tradition eu celle de "croyance".

4 'Uzhe v samom nachale yazykovoi traditsii ponyatie "doverie" rasshiryaetsya do ponyatiya "vera"' (Benveniste 1995, 124). 
evangelists of Rus'. But as Malcolm Ruel showed in a classic article, the originary meaning of pistis is 'trust'. Not only the Greek, but the original Hebrew term from which pistis is derived 'was used of the reliability or trustworthiness of a servant, a witness, a messenger or a prophet' (Ruel 1997, 38). We can see how theorists who insist on the close kinship of words and phenomena, such as Agamben, Derrida, and Heidegger, are liable to make us dizzy; for here a return to the origin of the word to 'catch sight of' the phenomenon to which it points leads one to conclude that trust (do-verie) is 'until or before trust'. How can something be before or until itself? One might employ the tricks of the continental philosophical trade and turn the prepositions and adverbs into nouns and nominals so that, in this lexicon, trust is 'the before' of faith, or faith's 'until' is trust.

Yet this hardly makes the phenomenon clearer. We might suspect from the quandaries above that trust-doverie shows something of that je ne sais quoi that Derrida called 'différance': the elision and obliteration of origin and ground in an endless cycle of deferral (Derrida 1978, 75). Trust-doverie's descent into différance would be an unsurprising discovery since, in a thorough recent analysis of the related notion of faith-pistis, Teresa Morgan says that faith also betrays the motile semantic slipperiness that leads into infinite regressions of différance: 'no one theory has attempted to locate trust, belief, their opposites and palliatives within a single model. A model, however, is to hand: that of différance or "deferral", in the Derridan sense. However we trust, and depend on trust, our trust always depends on something else' (Morgan 2015, 20).

These linguistic labyrinths might seem very abstract, but when the selfevidence of doverie-trust is breached in social life it can indeed seem to stand on thin air. One could take a famous literary example to make this groundlessness more concrete: Anna Karenina's husband, Alexei Alexandrovich. When the naïve husband tries to dispel his own doubts about his attractive young wife's fidelity, the groundless supposition of his trust is revealed: 'Alexei Aleksandrovich considered that he ought to have trust [doverie]. Why he ought to have trust [doverie], that is, complete assurance that his young wife would always love him - he never asked himself, but he felt no distrust [nedoverie] because he had trust [doverie] and told himself that he had to have it' (Tolstoy 2000, 142)..$^{5}$ Tolstoy's character gives us a further important insight into doverie and its risks: people trust others in the hope that by proffering the unbidden gift of trust, they will initiate a trusting relationship and will receive trust in return, though as Alexei Alexandrovich found out this gambit does not always work. 
Trust can therefore be taken as a transactional and relational phenomenon. Indeed, Beveniste's archaeology (Benveniste 1969, 177) showed that early Indo-Europeans understood trust as operating according to that maxim of Roman religion made so famous by Marcel Mauss's analysis of the gift: 'do ut des' ('I give so that you may give') (Mauss 2002, 22). What if we understood the circular relation of trust and faith in this model as different stages in the formation of transactional relationships? Trust might then appear as the elementary initial wager risked in the hope that it would be picked up, received, and, in so doing, turn an other into a recipient, partner, and potential giver/truster, in whose reciprocal regard the initial act of trust would be reified as a trustworthy relation. ${ }^{6}$ This initial risky and evanescent gambit would stand within the temporal conditionality of an 'until...': until Anna Karenina killed Alexei Alexandrovich's hope, he clutched onto the chance that his unfounded trust would be reflected in his wife's good faith.

Until the moment trust is picked up and consummated, the first move stands in a condition of suspended animation during which it gestates and incubates in a fecund temporal fold. At a later date this embryonic trust can either blossom or shrivel, or be violently eradicated, depending on the soil in which it was planted. If we take trust-doverie as 'until faith' together with faith's (vera) early etymology as trust, such that trust is 'until itself' so to speak, then the best approximation of what constitutes the abstract notion of something 'until itself' might be its gestation and incubation: the secret growth and pregnancy that moves towards birth. What was I 'until myself' if not my own potentiality-to-be that waited to be actualized? To adapt Walter Benjamin's image, trust in this reckoning would be the dreambird that incubates the egg of faith (Benjamin 1991, 447). This notion of gifting trust will help make our analysis more anthropological than etymological once we turn to the ethnography.

Transactionally, then, trust-until-trust (do-verie) would be faith held in suspended animation, a photographic negative, as it were, taken and developed of faith's potentiality to-be. Do-verie would then have the strange quality of anticipating its own outcome (faith) in order to performatively bring about that very outcome. Do-verie conceived as a play in an exchange would appear to be an other-directed hope and wish: it would stand in the middle between the subjective and objective viewpoints of the gift. Do-verie as until-trust would be the initial intention in the as-yet-pre-subjective/ objective stage that subsists in media res before the two terms of the relation

6 'The subjective truth of the gift [...] can only be realized in the counter-gift which consecrates it as such' (Bourdieu 1990, 105). 
are formed, in the conjunctive so-that of 'I give so that you may give'. This is done so that you may become you and I become I for you; it is given so that you may become a giver to me, I may become your receiver; this trust is placed so that you may be trusted by me, I may become your trustee; this elementary pre-faith (trust) is shown, which, until and by the fact of your reciprocation, might reveal itself as faith well-placed, and thereby create a relational space where words and deeds match up: the 'veridictive' space of faith (Agamben 2011). Grammatical reversals like these might point a way out of the vicious Derridean circle and towards a concept of how do-verie works in social life: as two performances that provide the contexts for each other or as two co-produced terms, trust and faith exhibit that canny ability of persons, relations, and cultures in general to operate like a tank that 'lays its own tracks' (Wagner 1981, 42).

In her analysis of faith, Morgan cites the conclusion of an 'Investment Game' that has become a test case for the field of behavioural economics: 'people tend to offer trust to those they do not know in the hope of creating it' (Morgan 2015, 17) In other words, people trust to be trusted. But behavioural economics, like opinion polls, treats trust as a context-independent thing outside of time, whereas the following ethnography will show that the modalities of do-verie depend on the frames of enactment in which they are brought forth: the 'When?', the 'How long?', and the 'Wherefore?' - those questions that are flagged by the simple shape of the Russian word itself. Whether the literalness of do-verie is enacted as 'before faith' or as 'until faith' will illuminate how different structurations of trust and faith have provided these Old Believers with junctures of solidarity and fault-lines of fracture.

\section{The Vladivostok 'patriots' versus the Bolshoi Kamen' revivalists}

In the mid-1990s, around $25^{\circ}$ people, most in their thirties, converted to the Old Belief in the major urban areas of Southern Primorskii Kray (Russia's Far Eastern Maritime province), specifically in the capital Vladivostok and the nearby 'closed city' where I conducted a year of fieldwork, Bolshoi Kamen'. ${ }^{7}$ From the beginning, there was a divide in the background and perspective

7 Because of the strategically important Zvezda submarine factory it housed, Bolshoi Kamen' was, until 2015, under the status of ZATO (Zakrytoe Administrativno-Territorial'noe Obrazovanie), which stands for Closed Administrative-Territorial Formation. Officially, ordinary Russian citizens had to have a special propiska ('residence permanent') to enter its environs. 
of the two groups that led this revival. On the one hand, there was a group of conservative traditionalists influenced by the nationalist ideas that had emerged and flourished in Siberia during the 1980s. These 'patriots', who were based in Vladivostok, took up Old Belief primarily as a banner for restoring Slavic traditional culture and Russian national pride, as well as an organizational rubric with which to erect a stiff barrier between svoi ('their own people') and chuzoi ('outside aliens'). Some of these 'patriots' claimed to have had Old Believer and Cossack ancestry, though all had a thoroughly Soviet upbringing: school, sports, army, work.

The other wing of the revival, based in Bolshoi Kamen', was led by a group of young pedagogues and kul'trabotniki ('culture workers') who practiced an intensely orthopraxic form of Christianity that reflected their previous exposure to Hare Krishna spirituality. This group saw Old Belief as a vehicle for a world-historical project of spiritual conversion and restoration, and therefore eschewed the exclusive nationalist and nativist emphasis of their Vladivostok co-religionists. The Bolshoi Kamen' revivalists invited people who, like themselves, had no family link to Old Belief, including non-Russians and marginal people such as ex-convicts, to convert to the religion and help them build a self-sufficient community.

Both of these wings or factions were originally evangelized in the late 1990 s by the talismanic Father Valery, at that time the only priest serving the Old Believers between Lake Baikal and the Pacific. A man of fierce charisma who had defected from the Russian Orthodox Church, Valery had spent the 1980 os passing through diverse centres of spirituality in his 'search for the truth'. The priest supposedly had the ability to bring anyone to the faith, 'from a banker to a street-sweeper'. ${ }^{8}$ In a few years, over 200 people were baptized into the Old Belief in Southern Primorskii Kray, including 57 of Bolshoi Kamen's young neophytes. Not only did Father Valery attract the young and idealistic to the Old Belief, but he also found a large and willing audience amongst Vladivostok's many enthusiasts of Slavic culture - the neo-Slavophile crowd whose numbers had been swelling throughout Russia since the 1970s. He converted members of the Far Eastern branch of the nationalist organization Pamyat (Memorial), a

8 Valery's spiritual wanderings had taken him to shamans' tents in Karelia, the mosques of Samarkand and Bukhara, and even Shinto shrines in Japan. He finally served at the famous monastery, The Trinity Lavra of St. Sergius, where he was ordained an Orthodox priest and entrusted with the terraforming task of transforming the Russian Far East's spiritual desert into an oasis of Orthodoxy. Back in Vladivostok, however, Father Valery's search for the untainted source of Russian spiritual truth led him to doubt that the state Church had faithfully transmitted that source after the great Schism on the 17 th century. 
charity that had originally grown out of the Late-Soviet Slavophilic 'village prose' movement to advocate for the protection of Siberian ecology and historical monuments. But during the 1980s, Pamyat gained increasing notoriety by distributing a virulent narrative of Russian history that claimed a Jewish-Bolshevist-Masonic-Georgian conspiracy had been responsible for 'the genocide of the Russian people'. 9

Valery also recruited Alexander Frolov, who soon became the chairperson of the Vladivostok community: a position he occupied in alternation with his wife over the next decade. Frolov espoused the views of the right-wing 'Russian National Unity' Party (R.N.E., russkoe natsional'noe edinstvo), an organization that castigated 'Western liberalism' and its notions such as 'quality of life' - a standard that it claimed was inapplicable to the 'Slavic soul'.

But Valery's much more liberally-inclined converts in Bolshoi Kamen' disapproved of their spiritual Father and his disciples' enthusiasm for conspiracy theories; they believed that he had gone too far beyond the canonical boundaries of Old Belief when he began to proselytize 'neo-paganism'. They denounced both him and Frolov for distributing the teachings of Valery Emelyanov, Pamyat's founder, the general content of which can be gleaned from one book's title:Desionizatsiya ('De-Zionization'). Father Valery started to preach his neo-pagan message instead of Orthodoxy, proclaiming that 'we Russians for a millennium have been duped by the lying message of Kike-Christianity' (zhido-khristianstvo); instead, Valery insisted, Russians must return to 'worshipping their veins!' When Father Valery compromised himself through participation in a pagan fire-dancing festival and feast that was broadcast on local TV, his ambitious young adepts in Bolshoi Kamen' - keen to use the Old Believer diocese as a Russia-wide vehicle to realize their own spiritual vision - took advantage of this public lapse to depose him and take charge of the revival themselves. Naturally, the 'patriotic' wing of the revival in Vladivostok led by Frolov (who also attended the Slavic pagan feast) thought that this ousting of their spiritual Father was an act of treachery. Henceforth the 'patriots' nursed a grievance against the young new priests who had masterminded this 'coup' - all of whom came from the Bolshoi Kamen' revival. This cleavage between the 'patriots' and the Bolshoi Kamen' activists was a fault-line that would periodically be the cause of eruptions in times of tension.

The Vladivostok community had one advantage in this battle for control over the Far Eastern Diocese: it was the richest in the region, thanks to its laity's engagement with biznes. Frolov, for instance, owned a computer 
trading firm, while other parishioners were engaged in forms of more or less legitimate 'commerce' in the city. 'Patriotic' ideas seemed to particularly flourish amongst this class of small city-dwelling businesspeople and Orthodox laymen. The Vladivostok community tried to put the brakes on Bolshoi Kamen's attempt to resurrect the Far Eastern Diocese and their Church-building scheme by selectively withdrawing financial support. Following a dispute in which the Far Eastern priests had broken off communion with the Moscow Metropolitan, the Vladivostok laity led by the Frolovs concluded that it was 'impossible to trust such priests' (nel'zya doveryat takim svyashchenikam'). They exhorted other Far Eastern laity not to trust the priests' 'brotherhood' ('ne doveraite bratsvu!').

The Bolshoi Kamen' community, led from its inception by a charismatic former Komsomol secretary who became, in the fullness of time, their Archpriest, was completely different from its Vladivostok counterpart in the history of its formation, the background of its parishioners, and its everyday operation. Whereas the kernel of the Vladivostok community brought together biznesmen 'patriots' with a closed group of Old Believers who formerly had worshipped without priests ( known as bezpopovtsy 'the priestless'), the Bolshoi Kamen' obshchina ('community') came out of a late Soviet neformal'nyi ("informal" youth association') that in the first dawn of the post-Soviet period briefly morphed into a Hare Krishna commune, until finally crystallizing into its Old Believer avatar. ${ }^{10}$ Virtually none of the Bolshoi Kamen' community members had been brought up as Christians; some even said that only as teenagers had they learned of the existence of such a religion by listening to foreign radio broadcasts. All of its members were, therefore, in some sense converts: for each person the turn towards Old Orthodoxy marked a break with their immediate, objective pasts.

The Bolshoi Kamen' community took from its pre-history as an 'informal' youth group the desire to contribute to the betterment of society and the common good, especially through the education of young people. It opened the community up to certain sectors that might otherwise have been excluded from Orthodox enchurchment. Ex-prisoners, recently released from the Far East's swelling jails, were invited to live at the community's base in return for their obedient work and service. For these men, many of whom became deep and faithful Old Believers, the community was an asylum to

10 During perestroika there was an explosion of these neformal'nyi associations, so called because of their independence from the komsomol (Communist Youth). They briefly exerted an important influence on Russian politics, circa 1988-1990. 
which they could escape, create a new life for themselves, and break from the previous associations that had led them into trouble.

The Church also provided a surrogate and alternative family for these men, most of whom had by choice or compulsion broken the links with their own kin. Indeed, the relationship between priest and flock was defined as one of parent to child: the confessant calls his confessor his dukhovnyi otets ('spiritual Father'). The relationship between spiritual father and child was, moreover, a conduit of exchange: in return for his subordination, the spiritual child could offload his sins onto 'the neck' of his father who, in turn, would wager his moral person as a spiritual surety guaranteeing his flock's sanctity. This mutual exchange of sacrifices (of sinful autonomy for hallowed heteronomy and hierarchy) was the sinew of this community's Eucharistic body.

In the Bolshoi Kamen' community, many of the ex-convicts adopted the separate status of poslushnik ('obedient'): an ecclesiastical status well below that of a monk but that still carried some of the strictures of monkish life. This group of men lived in a semi-permanent status of spiritual debt-bondage to their father-confessors. This negative reciprocal relationship induced a certain functional stability in the Bolshoi Kamen' community. The status of these 'canonical penitents' meant that the community had a localized and gathered 'estate' of workers who lived separately from the families of the priests in the 'monastery', and who managed to live a moderately dedicated Christian life, without holding the elevated spiritual status that comes from being a monk. ${ }^{11}$ These canonical penitents could take on the burden of otherwise sinful activity for the sake of the priesthood, thereby establishing a 'spiritual division of labour'.

The Bolshoi Kamen' community could also rely on the support of another Church 'estate' that had been created through the innovative restoration of an almost forgotten ancient Orthodox institution. Because not all of the people who would have wanted to convert to Old Belief were immediately able or willing to rupture the worldly links in which they had hitherto been entangled, the priests encouraged such aspirants to become catechumen in the Church, an ecclesiastical status occupied until baptism, when the initiate is catechized into the faith. These long-term adult catechumen

11 Simon Kordonskii (2008) argues persuasively for treating post-Soviet Russia as a society composed of various titular 'estates' (status groups that possess different rights and duties): there are different kinds of people in Russia, not homogeneously abstract citizens equal before the law, but Duma Deputies, Soldiers, road-side Militia, Cossacks, Priests, paperless ex-convicts, etc. 
could gradually convert to Old Belief by re-orienting their way of life over years so that, when they were eventually baptized, they could then uphold the strictures of being inside the faith.

Many of these catechumen, unlike the ex-prisoner poshlushniki or penitents, were actively engaged in the cut and thrust of work and biznes in the Russian Far East; they therefore had to negotiate situations that were difficult to reconcile with upholding a strict Christian morality. The status of catechumen suited their situation: while it gave them a temporal horizon for the deepening of their Church involvement, they could also continue their worldly engagements without incurring mortal sin - at least until baptism, an event which could be and often was indefinitely deferred. This estate, moreover, complemented the functional organization of the Church by providing it with the manpower to fulfil tasks and extend the Church's influence beyond its numerically small congregation. Since they still had to complete their baptism (they were do-kreshenie) their inclusion depended upon their priest-mentor's discretion and so, like the penitents, the catechumen were obliged by bonds of reciprocal dependence and hierarchical subordination.

Finally, the core of the Bolshoi Kamen' community formed around a group of recently ordained priests and their extended families. These priests became Godparents and confessors to each other, so they were closely intertwined in the bonds of spiritual kinship. Some having six or seven children, these young families had originally envisioned a future as an endogamous unit on the model of the Old Believer diaspora, whereby their children would be educated away from mainstream Russian society and would eventually marry each other. A few of the priests' families did intermarry: Father Konstantin's sister was Father Sergei's bride. But in practice, as this community developed over the first two post-Soviet decades, this plan of endogamous spiritual families proved to be unrealizable (the absence of women converts was a decisive hindrance). Nevertheless, these priests' young families still provided a crowning image of an Orthodox ideal towards which the imperfect and fallen faithful who aspired to spiritual wholeness could strive and in which they could participate through their service to the community.

The extended Bolshoi Kamen' parish-community with its spiritual division of labour can be construed as running a kind of generalized exchange (Levi-Strauss 1969): obedients-A gave sea cucumbers to laypersons-B, who gave a car to priest- $C$, who gave an inspirational sermon to catechumen-D, who in turn donated parts for the boat in which the obedients-A went diving for sea cucumbers, and so on. There was an exchange of sins and 
services in a non-egalitarian relationship between the priest-father and his confessor-children, who were together already caught up in the unfinished business of the sin-for-service exchange. The immediate giver was construed merely as the intermediary through whom gifts were transferred from the anonymous donor who always stood at least one remove away: the generalized economy of God's grace on earth - the Church. This incessant activity spun on the ongoing deferral of the 'until': the do-verie in which this faith was imbricated. ${ }^{2}$

The Vladivostok community, by contrast, was in a restricted exchange with their clergy, whom they reputedly treated like naemniki ('mercenaries'). They denounced the system of extended reciprocity by which the other community flourished with an 'objectivist' violence that ripped these transactions out of their living enactment (cf. Bourdieu 1990): Frolov dismissed these exchanges as brakon'erstvo ('poaching') - a questionable judgment from a biznesmen whose computers allegedly bore a somewhat dubious provenance.

\section{Fighting over the faith}

While the priest confessor-fathers formed the hierarchical apexes of the distributed community, this vertical imperative was balanced by the demotic principle that was embodied in the Orthodox sacrament of sobornost (catholicity). Regular meetings, congresses, and synods were held, in which the different 'estates', including the laity, obedients, and even catechumens could raise questions and make proposals about the governance of the Church. The Vladivostok parish often refused to send representatives to these events, which they described derogatorily as 'dem-sobornost' (pleb-catholicity). They claimed that these meetings had a hidden agenda. Whenever such meetings were held in Vladivostok reasoned discussion quickly descended into accusations and backbiting. Father Konstantin and the other clergy who presided over these occasions struggled to keep in check a laity that regarded the priesthood not as their gentle shepherds but as employees who should fulfil their will.

The situation reached breaking point when the 'patriotic' laity started to interrupt the officiating priest during services to claim that he was

12 In practice, the exchanges did not function as mechanically as the structural model implies. Putting them in these terms merely helps to convey a difference in the spiritual economies of the respective communities. 
performing the liturgy incorrectly. So torn by bitter feeling was this congregation that the entry of parishioners who supported the clergy into a church service would prompt the exit of the others who denounced them. The Vladivostok laity continually disagreed about the content and import of the faith, both with their clergy and each other. They quoted verses from the gospel to justify their truculence and accusations: 'If your brother or sister sins, go and point out their fault [...] if they will not listen, take one or two others along, so that "every matter may be established by the testimony of two or three witnesses"' (Matt 18: 15-16). This flurry of apostolic citations so undermined the priests' tenuous authority that they forbade all mention of the gospel: the 'gospel was for heretics', so they 'agreed not to discuss Christ' but instead concentrated on ceremonies and singing "zhertva, penie" (ceremonies and singing) in an effort to build a consensus by means that bypassed the discussion of the faith.

When even this injunction failed to stem the barrage of abuse, Father Konstantin declared a spiritual state of emergency, called an "vneocherednoy" (extraordinary) session of the Church council (sovet), and instructed his congregants that since 'love was gone, it was necessary to live by canon' that is, since all harmony between parishioners and priests had evaporated, it was necessary to rely upon a bedrock of strictly non-negotiable rules. That even this ground zero of linguistic interpretation (a rule shorn of all ambiguity) could yield oppositional viewpoints showed that the Diocese was caught in an unsurpassable discursive deadlock. Rules, Wittgenstein teaches us, in themselves provide no more of a ground outside of interpretation than any other kind of expression: 'any interpretation [of the rule] still hangs in the air along with what interprets it, and cannot give it any support. Interpretations by themselves do not determine meaning' (Wittgenstein 2010, PI 198 A). At these turbulent meetings, parishioners kept shouting ever more shrilly and banging their fists on tables: 'On what basis [na kakom osnovanii], on what canonical basis do you make such claims?' The fact that this ever-deeper search for a foundation to adjudicate their arguments merely took them further into an irreconcilable interpretive impasse laid bare the absence of a real pillar on which they could rely. No certainty would come from discussing the faith.

The constant disagreements had a more fundamental and insoluble nature than the subtleties of theology and canon upon which they gave endless exegesis. Language had become merely the rhetorical shell and epiphenomenon of a dispute whose roots extended subterraneanly into that miscellaneous hinterland of non-linguistic experience, the silent traces deposited in bodies and memories buried in things where forgotten histories 
and obsolete politics play out their afterlife. Arguments over the minutiae of the faith became merely a dressing covering the fracture that lay in habits and trajectories that preceded both groups' turns to Old Belief: that went back to conflicts 25 years before, when each had stood on different sides of the barricades during Russia's aborted transition to democracy. One wit made a laconic but perspicacious comment on the source of the confessional conflict by reducing it to a political caricature. He said that it was: 'General Lev Rokhlin and the brothers Rotkin versus Gaidar and Gusinskii'. ${ }^{13}$ In other words, it was right-wing, pro-Soviet, Slavophile supporters of a military junta against pro-democracy, liberal, and outward-looking economic modernizers. But it would be wrong to take from this half-joke the impression that this dispute was a political war fought by religious means: despite the wit's bathetic reduction, each party earnestly thought that they were standing up for the Orthodox faith rather than adopting some crypto-political position.

The major practical symptom of this rift was that the wilful and contrary lay leaders such as Frolov refused to confess to the priests, and so broke off the elementary relationship between confessor and confessant and the spiritual reciprocity engendered thereby. Instead, they kept switching between different confessors, since unloading their sins onto their spiritual father would have been an act of capitulation and would have enjoined reciprocal obligations into the future. The priests spoke of these rebellious laity as "nevospitanyi" (delinquent, ill-mannered) school children . In turn, the Vladivostok laity ramped up the discourtesy and began to refuse elementary hospitality to their clergy: they declined to invite them to the table for a meal; and they withheld from bishop German his train-fare home to Khabarovsk - by asking for which, they alleged, he was behaving kak tsygan ('like a gypsy'). This cessation of basic Christian commensality in effect sundered the Eucharistic body. The bishop declared that the community consisted of 'bandits'; of their Church, he said: 'this house is swept and empty' (implying with this gospel citation that the community was

13 The brothers Rotkin refers to the current leaders of the ultra-rightwing organization 'Movement against Illegal Immigration' and 'National-Patriotic Front Pamyat'. General Lev Rokhlin was the military hero who took the Chechen capital, Grozny, in 1995 but refused to accept Russia's highest military honour for his valour. He later became a political mover who reputedly wished to replace Boris Yeltsin's regime with a military dictatorship, but was murdered before making an attempt to do so. Yegor Gaidar was the Russian economist, politician, and architect of "shock therapy", the sudden withdrawal of state subsidies and release of price controls that overnight pushed millions of Russians into poverty. Vladimir Gusinskii is a Russian media tycoon, funder of Russia's liberal opposition and a outspoken Kremlin critic. 
Figure 10 'Patriotic' chairperson of the Vladivostok Old Believers Aleksandr Frolov (left) with Episcop German (centre)

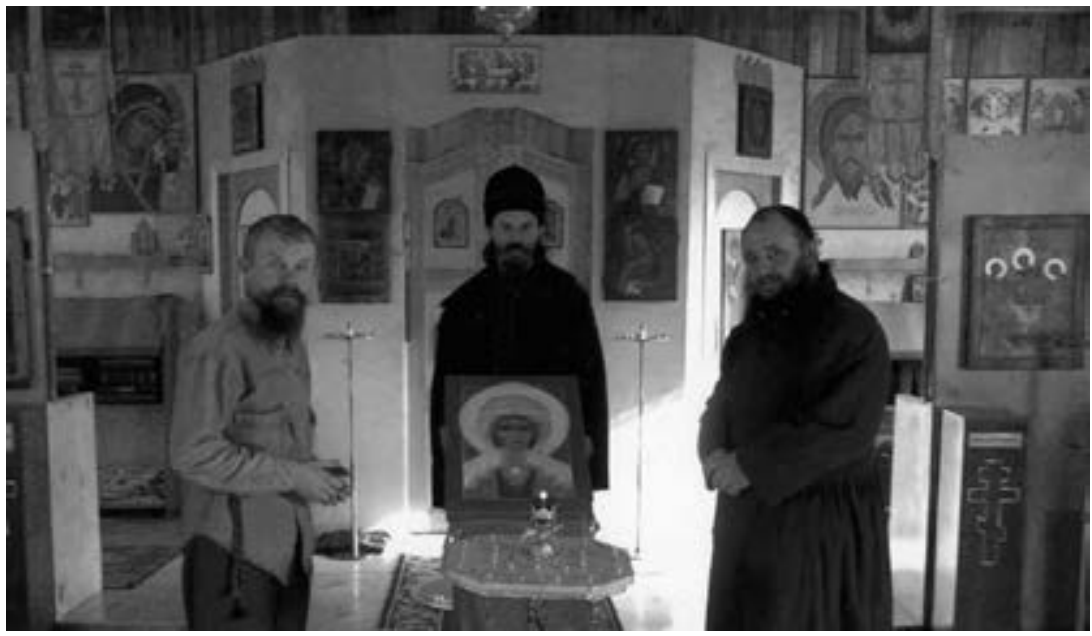

Figure 11 A s"ezd ('congress') of Far Eastern Old Believers in the mid-1990s held in Bolshoi Kamen'

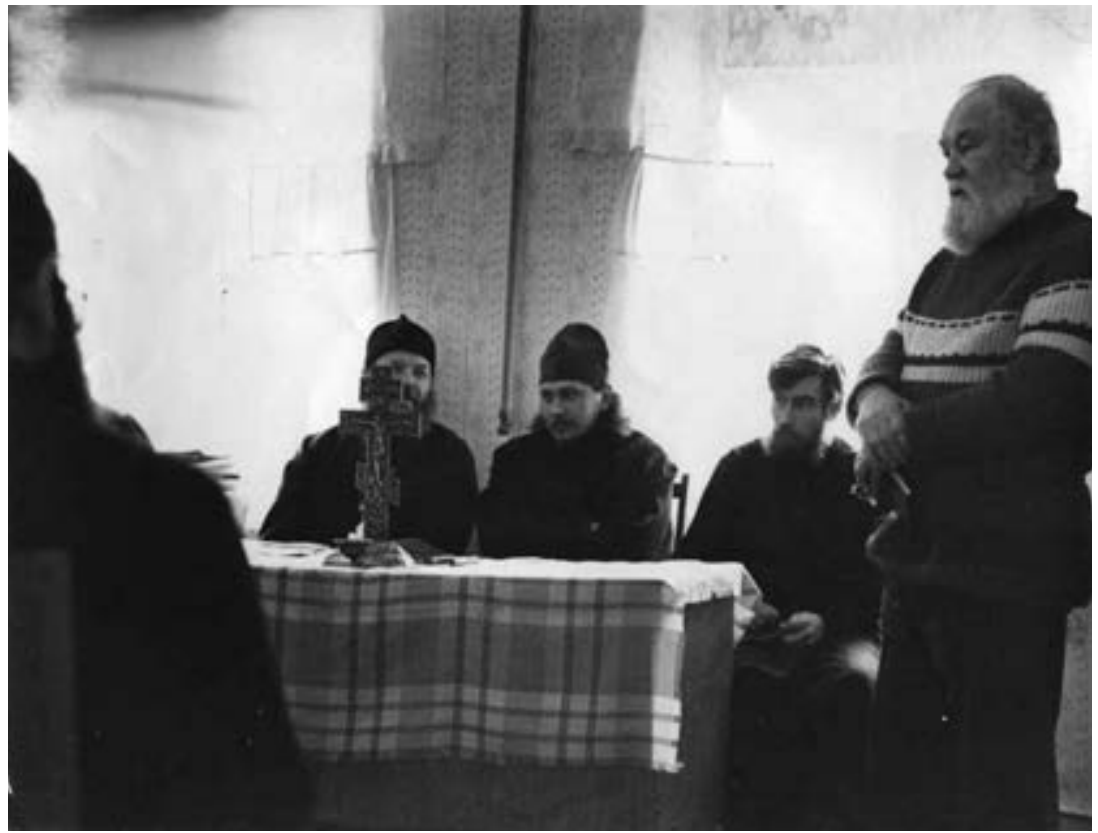


governed by an unclean spirit). ${ }^{14}$ In the middle of the night, the bishop was strong-armed out of the Church premises.

While the Archpriest exhorted these suspicious parishioners to 'trust in the power of the priesthood', lay leaders responded that 'to trust your priests is impossible'. It seemed as if the word doverie meant different things to these different groups: rather than some stuff ('trust') lacking between them, each community seemed disposed to consider different sorts of relationships as trustworthy or not. Pledges and assurances heaped on top of each other did nothing to bring these sides closer; their divergence was not simply a deficit or shortfall that could have been papered over with another legislated edict. This lack of doverie was not simply between the Bolshoi Kamen' and Vladivostok communities, but to some degree also internally between the members of the Vladivostok community. Just as one side in the conflict could interpret a seemingly unambiguous Church canon to have the opposite import to the other's interpretation, so the notion of trust seemed to hang in the air without a common ground. The difference between the Vladivostok and Bolshoi Kamen' communities' appreciation of doverie instead lay at the level of what Talal Asad calls 'the lived grammar of devotion' (Asad 2015). ${ }^{15}$

\section{Before-faith as fore-faith}

But how could the lived syntax of faith be arrayed in such a way that these Christians' respective apprehensions of doverie-trust interfered with each other at a fundamental level? If, as suggested at the beginning of this chapter, we treat trust not as a pre-existent object that is picked up by a corresponding linguistic reference to a state of affairs, but as a potentiality of becoming attuned to the different aspects of a situation, bringing into greater relief certain dimensions of relationships, and disclosing the multiple possibilities of people and things, then we might be able to pinpoint this fundamental fault-line. Treating trust as a certain disposition towards the world helps to flesh out the point that the conflict in the Diocese was not over some particular thing - since they picked anything and everything

14 The biblical reference is to the parable of 'the return of the unclean spirit' (Matt 12:44, Luke 11:25).

15 Asad used this pithy phrase when he delivered a paper at the American University of Beirut (25/92014) https://www.youtube.com/watch?v=k4a1idgurBc. The phrase was omitted, however, from the version published in Critical Inquiry. 
to disagree about - but instead came from how such content got refracted through pre-existing, non-discursive habits and tastes ('lived grammar').

Since these differences lay at the very level of embodied syntax, the constitution of the word do-verie and its import starts to reveal its significance. As mentioned before, the word doverie suggests that trust lies in or around the field of possibility that is connected to faith, especially its temporal ordering. If we look at the Vladivostok community, it is clear that their trust in Old Belief was elicited from things rooted in a deep and imagined past, in Slavic blood-and-soil traditions. Deviations from this primordial template provoked the default knee-jerk insinuations of Soviet suspicion, such as denunciations of priests as 'agents provocateurs'. The 'patriots' also denounced the revivalists in terms of certain Soviet standards of normativity, cleanliness, and culture: they saw these neophytes' conversion of a military compound into a Church not as an ingenuous use of infrastructural resources but as a 'dirty barn', while the barracks that were transformed into a monastery were framed not as a spiritual retreat but a bicharnya ('homeless hovel'). Nor did the priests manage to satisfy these parishioners' expectations of gendered patriarchy: they were 'weak', 'not authoritative', and podkabluchniki ('under their wives' heels').

In sum, the 'patriots' were attuned to seeing a person as trustworthy according to what that person had been 'before faith'. While the Bolshoi Kamen' Christians said that they believed wholeheartedly, after the credo, in edino kreshchenie vo ostavlenie grekhov ('the one baptism for the remission of sins'), the Vladivostok 'patriots' thought that a person's prior involvements still had a decisive influence on them, even after baptism. They admitted that this might not be a completely Christian message, but insisted that forgetting the past and being without memory was to cease to be a Russian at all. They quoted the Russian proverb kto staroe pomyanet-tomu glazvon, a kto zabudet - tomu oba von ('he who reminds of the past will be deprived of an eye; he who forgets it - of both'). 'Yes, perhaps it's not a Christian sentiment', remarked one layperson to justify this attitude, 'but y'know all of us are far from living up to the name of Christians here, and after all it's forbidden to be without memory and without ancestors' (bespamyatnym $i$ bezrodnym). In response to the question, 'Do you not believe that baptism washes away sins?' and her fellow Christians' exhortation to let bygones be bygones, Laywoman Frolova commented that 'when the past does not influence a person, then we do not remember it, but when that past shows an overwhelming influence in a moral-ethical arrangement (ustanovok), then we look for the root of that behaviour'. She more concretely specified the past in which she felt this moral-ethical aberrancy was rooted, identifying 
a 'residual reflex (ostatochnyi refleks) from these persons' time spent in krishnaizm' (Hare Krishna).

This view that the past has an decisive influence on one's present persona was as applicable to these lay 'patriots' themselves as to the former Hare Krishna devotees whom they denounced in such terms. The laypeople in their forties and fifties betrayed a worldview indelibly shaped by certain Soviet ideas, especially a historicist conviction in the causal role of the past for determining the present and a related etiology of origins and sources. Using Soviet terminology, they called themselves korennyi ("rooted" or indigenous) Old Believers to distinguish themselves from what they considered imitative neophytes. They authenticated the genuineness of their ethnoconfessional identity by reference to their putative origins rather than to any living Christian conduct. They deployed this nativist hermeneutic towards everything, and betrayed an almost Stalinist view that people's (often hidden) origins caused their (usually secret and sinister) behaviour. ${ }^{16}$

In their diatribes against the revivalists, the Vladivostok laity particularly singled out the name-changes of the priests, especially that of the Archpriest, whose name prior to conversion was a constant source of rumour. The Vladivostok 'patriots' argued that this shape shifting covered up a hidden past that needed unveiling. In their eyes, the Archpriest had changed his suspiciously un-Russian sounding family surname to conceal his origins (origins that, like Vladimir Illych's, could no doubt be traced a few generations back down the 'mother's line' to reveal miscegenation, according to this hermeneutically suspicious a priori). ${ }^{17}$ As if to corroborate this closed logic with a final conclusive flourish and an incontrovertible axiom, Frolov added to his wife's remarks: 'After all, was Kaganovich a Russian? ${ }^{18}$

From the outside, the Vladivostok lay 'patriots' considered the interweaving of the Bolshoi Kamen' revivalists' relations between confessor and confessant, Godfather and Godchild, to form the hard core of a coven of intrigue. They referred to this intertwined confessional unit with the term zaedinshchina, literally 'all-for-one [one-for all]' - a Soviet-era term for a group sworn together and united by a conspiratorial venture: 'They are all so intertwined with each other as confessor and flock that they are probably concealing in the bowels of this spiritual zaedinshchina secrets that

16 See Ssorin-Chaikov (2003) for how origins were 'othered' through the gaze of the Stalinist Soviet state.

17 See Yurchak's (2013) analysis of the eruption of discourses about Lenin's corrupt 'Semitic' origins in 1990.

18 Lazar Kaganovich (1893-1991) was a Stalinist commissar of Jewish ancestry. 
prevent them being priests. It was thought up from the beginning! Nothing unites people better than common crimes'. They also accused the priests with the typically Soviet denunciation of 'careerism' for their attempts to try to build up the diocesan structure. The Soviet-reared Vladivostok lay leaders seemed to have filtered into their faith the default attitude of Soviet suspicion, denatured only of its ideological content. This is a stance that Andreas Glaeser calls the 'socialist categorical imperative', in which every action should be tested against the question 'Who benefits?' - us or the (capitalist class) enemy? (Glaeser 2011, 108).

Such a fraught encounter freighted with mistrust implies not an absence and lack of trust, I argue, but the interposition of an intervening form of trust through which these relations between priest and poslushnik, these places such as the homemade churches, always already appeared to the Vladivostok laity as untrustworthy. Do-verie for them was a structuring structure that carved out the borders of their faith, in which some could commune and from which others would be excommunicated. They therefore took the lived grammar of do-verie as 'before-faith' in two senses. First, whether they trusted a person or not depended on who and what that person had been prior to their enchurchment (their profession, their background, their class/estate): this appraisal was independent of any transformation Christian conversion might have wrought in the person (the who of the faithful depended on the 'when?' - before - of trust). Second, they had do-verie in the more fundamental sense of a fore-faith, on the basis of which, like for the rest of us, the significance and intelligibility of the world is always disclosed by way of a set of pre-given structuring dispositions.

In phenomenology, 'the fore' is always-already-having-the-world-thusand-so: the fact that one grows into a world that seems pre-interpreted to have significance. 'The fore' is that which lets people and the relations between them and things appear as trustworthy or not, which lets a tightknit group appear to be a conspiratorial unit or a non-Russian surname seem Masonic-Jewish. 'The fore' is an inheritance by which the world is contoured in advance for the people who are brought up inside a culture - such as a Soviet civilization in which the determining power of origins was axiomatic. ${ }^{19}$ Husserl felicitously named this pre-delineation of reality so that the outline of the future is pencilled in and trustingly taken for

19 'Coming into the world, one grows into a determinate tradition of speaking, seeing, interpreting. Being-in-the-world is an already-having-the-world-thus-and-so. This peculiar fact, that the world into which I enter, in which I awaken, is there for me in determinate interpretedness, I designate terminologically as the fore-having [vor-habe]' (Heidegger 1962, 186). 
granted before it arrives 'Vorglaube' ('fore-faith') (Husserl 2006, 117) - or, to calque the German into Russian, do-verie.

It is worth separating these two levels of interpretedness, for doing so allows us to catch a glimpse of the specificity of the Vladivostok laity's trusting suspicion: it allows us to see how their fore-faith was structured as a 'before-faith'. The trusting attitude and habitus that they carried as part of their everyday coping (their 'fore-faith') apprehended as trustworthy only those people and relations who passed the Soviet-style litmus test of demonstrably pure origins: those who 'before faith' were by Soviet standards 'normal', not Hare Krishna devotees or ex-cons. These laypersons' fore-faith pre-structured the composition of the faithful in whom they could have trust - namely only those whom they would have trusted in their previous lives, 'before faith' - in spite of Christianity's transformative message.

If, according to Husserl and Heidegger, everyone is born into a tradition of do-verie and inherits a fore-faith by which some persons are expected to be good while others appear suspect, the question arises whether this inherited structure can ever change. We have described one way of attuning this fundamental level that stretches between faith and trust: in the Vladivostok Christians' fore-faith as before-faith. Next we will see how an authentic conversion to Old Orthodoxy could rearrange the living syntax of trust and faith into a very different order.

\section{The lived grammar of Christian do-verie: 'until-faith'}

Nearly all of the male congregants of the Bolshoi Kamen' community (those who held me in their confidence) told me that at some time they had reached a turning point when they finally, as they put it in the Russian phrase for Christian conversion, prishel $k$ vere ("came to/arrived at faith'). This arrival did not necessarily coincide with their baptism - some recalled being baptized as children when they had visited relatives in European Russia - but, like St. Augustine, it was only their subjective commitment as adults that gave this nominal Christian allegiance any significance. 'Coming to faith' was often described as a time when these men recognized that their lives had an immanent logic and goal. As a result of arriving at faith, things that had not previously made sense (events, character traits, habits) found their place and their purpose: they had been markers on this path to faith. This was a very different apperception of the past from the 'native', korennyi ('rooted') Old Believers, who considered their enchurchment in the Old Belief a return to their deeper, truer, purer 
roots. For the converts, conversion instead took the form of a moment when the chaotic kaleidoscope of their own pasts rearranged itself into a coherent order.

One priest, for instance, recalled how, before converting, he had agonized over whether to move to Khabarovsk or to stay in Bolshoi Kamen'. Rather than list arguments pro and contra the move, he had started to recite these two city names silently over and over, meditating on the light palatalization of the latter and the harsh throaty expiration of the former, until he decided to stay in the liltingly labile Bolshoi Kamen' - where, soon after, he met up with the Christians. He retrospectively interpreted this vacillation as an elementary and unconscious attempt at what John Chrysostom called a 'prayer of the heart'. From the moment he came to faith, he realized that this was the meaning of his hesitant soliloquy; until that realization, he had merely trusted in something guiding him. One poslushnik similarly wondered why, long before hearing of Old Belief, he had never smoked and had always grown out his beard. Only retrospectively did he see that his following of these famous Old Believer habits divined and anticipated the outcome of his spiritual destiny. These Orthodox converts did not trace their pasts backwards toward the discovery of an origin (a salvage mission necessitated by the inexorably rushing movement away from true, untainted essences); instead, their biographies led up to the point at which all that preceded them was transfigured into and curated as an interim stage that led up to their arrival at faith.

How long did it take someone to reach the decisive moment that led to the door to faith? The length of the journey and the terrain traversed depended on each person's destiny, the revivalists said. Did some of the priests regret having been Hare Krishna devotees? No, they insisted - because without that experience they would not have alighted onto the true ancient Orthodox faith in the first place, nor would they have been able to put up with the initial austerities of its spiritual discipline, to which the Vedic spirituality had already accustomed them. Did some poslushniki regret the years they had been locked up in the prison colony? Absolutely not - since the ex-cons agreed if they had not been imprisoned they 'tochno ne prishel by!' ('certainly would never have come to the faith!'). During these necessary yet unconscious stages of their spiritual development, the wayfarers claimed that in their searching and erring they were nevertheless holding out for some as yet unknown goal: their spiritual careers partook of an 'unfinished time' (Asad 2015, 167). Once they had crossed the threshold into the language game of faith, these men retrospectively recast their final departure from and sacrifice of their old lives as the counter-gift that they 
owed to God for the grace, which they had already received from Him but until now had failed to recognize: His trust in their salvation.

These Old Believer converts therefore looked sympathetically at the current batch of aspirants who had not yet arrived fully at faith and still had to make the leap over the threshold of trust into faith proper: the catechumen or the lapsed who were 'still swimming' in the world. The catechumen and penitents were struggling to balance their accounts because they were inadvertently in arrears to God, insisted their more stalwart brethren. But unlike the post-Soviet Far East's first converts, who had struggled alone in 'a spiritual wilderness' and had needed to build up the ecclesia from nothing, at least these neophytes had a road marked out for them in advance to chart their progress towards faith. It was as if the stages of gestation and of giving birth to a new Christian had been hypostasized into several institutions by the Bolshoi Kamen' community: as if 'trust' itself had been institutionalized as a grade in the Church that one held until "trust", understood as the trusting stance of a convert's do-verie ('until-faith'), proper was achieved.

The gestation of faith in the shadowy rafters of the Church as instituted do-verie was given firm temporal and spatial coordinates. The catechumen were able to live with a temporally liminal status, metaphorically standing 'at the door' of the Church until they came to faith. The penitents could meanwhile indefinitely inhabit a delimited zone in the monastery, between 'the world' and that definite telos toward which they endeavoured: a whole and complete Christian life with a house, wife, and child. The Bolshoi Kamen' community therefore had a structure similar to the Early Church: within it doverie-trust was not just a subjective burden borne by the aspirant, but was laid out in a series of pre-structured, objective positions and roles. Foucault has commented upon how what later became a battle inside one's own subjectivity, was originally given externally embodied and socially marked determinations. ${ }^{20}$ In Bolshoi Kamen', as in the Early Church, the subjective spiritual battle of trust (living until-faith) was crystallized into an objective apparatus for the benefit of the faithful through a series of partial inclusions, in which doverie provided a space 'in the middle voice' where trust could grow and be grown.

20 '[Fourth Century Church Father] Pacian, for example, says there are three orders of Christian. There are the catechumens, who are those, so to speak, at the door of Christianity and will enter it. There are the fully practicing Christians. And then there are the penitents. Penitents are an intermediate order between catechumens and fully practicing Christians, and it may well be that this order had gradations and that there were sub-orders within orders' (Foucault 2014a, 196). 
How were these Bolshoi Kamen' Christians parsing the 'lived grammar of devotion' differently from their Vladivostok counterparts? For them the do- of do-verie did not answer the question 'When?' or stand as a placeholder for the dispositions of trusting certitude accreted from experiences and identifications 'before-faith'. Instead, in the syntax of their lived faith doplaced their action under the temporal condition of an 'until': trust was their response to the question that faith begs of all of its seekers, namely 'How long?' ('How long till I arrive at faith, how long till my world is transformed by Christ?'). For these converts, according to this phenomenologicalethnographic analysis, to have trust was to embrace and to hold onto the do- of do-verie, the trusting until of faith: to hold onto the uncertainty of how long it will take until one reaches this perpetually deferred destination. This stance was elicited not only from the catechumen or penitents, but from all of the Christians who vigilantly 'guarded their treasure' of faith and tried never to take their gift for granted. In this devotional attitude, do-verie was to abandon the certainties rooted in a fixed and frozen past (the adverbial before of a before-faith); it was to live within a time-space that partook of an unfulfilled past and unfurling future (the prepositional 'until' of a trusting attitude). While these Russians kept slowly paddling in the direction of faith - in that indefinite interim they had trust: 'Blessed are those who believed yet have not seen' (John 20:29). Do-verie until-faith was the condition of those who were willing to hold out and risk themselves for the reward of faith, having not yet received the counter-gift that consecrates a possibly solipsistic and ignominious act, which is the possibility that haunts the gift of trust when it is given faithfully to the Other, above all to an invisible deity. Trust-doverie therefore was endurance in the uncertain how-long of faith's indefinite penumbra - until-faith.

\section{The psychology of (ne)doverie}

But in what sense can these collective dynamics be labelled 'trust'? It is true that the two modalities of trust-doverie outlined above depart from how Russians in ordinary language usually speak of 'trust'. Instead, we have traced two possibilities that were uncovered by stripping the word doverie of its everydayness to disclose its existential core. The formal indications of this word have guided a phenomenology of the divergent temporal enactments and communal framings that emerged with particular starkness during the schism in the Far East Old Believers Church, when divergent routes to and from Christian subjecthood and the Soviet past were revealed. The 
two variants of do-verie described thus far are not, therefore, the cognitive, psychological, or intersubjective and dialogical meanings often ascribed to 'trust'. In the same way that the indexical 'I', the subject of enunciation 'I', and the grammatical subject 'I' do not necessarily coincide with - and often diverge from - the psychological 'I' (i.e., the seat of psychologicalcognitive identity), the abovementioned lived grammars of trust do not reside 'inside' any individual believer, nor can they be attributed to any single verbal statement made to the ethnographer. Instead, do-verie was enacted or disrupted through the ongoing practical process of Christian communal life. This analysis has been arrived at through reading the tacit interpretative frames that were made explicit during the schism. But this analytical emphasis should not ignore or obscure the importance of another modality of trust-doverie, perhaps the word's more taken-for-granted meaning: namely, the psychological certainty and confidence that one person has in another.

To make clearer the difference between the communal-ontological and personal-psychological structures of doverie, it is worth dwelling on an example from a recent field trip to Bolshoi Kamen', when a deeply faithful believer questioned me about my writings about his community. I had not yet shown him my thesis and he thought I was being evasive about its contents. He said that, because of this barrier, 'nedoverie had entered our relationship'. He told me that his nedoverie came from his uncertainty about whether he truly knew who I was. This pious young believer deployed a hermeneutic of depth that scanned for more reliable indicators of internal belief than mere religious observance. For him it was not enough that I participated in prayers, nor that I grew a beard and behaved, for all intents and purposes, no differently from the other worshippers in the community. Instead he insinuated that I was a 'simulator': someone who performed the rituals while hiding my true self behind the screen of ritual display. There was some suspicion that behind my amiable demeanour lay a quasi-spy who intended to expose the personal idiosyncrasies of his brethren to an unknown audience.

Christianity subjects its adherents to 'truth procedures', by which believers are compelled to publish and expose their internal states to each other or to their spiritual directors. The Christian thereby performs a 'veridiction of the self': an act that simultaneously both reveals and constitutes his or her 'true' self (Foucault 2014b, 125-199). The translation of these Christian practices of self-publication and self-exposure into Soviet techniques of monitoring and self-criticism have been described exhaustively in Oleg Kharkhordin's $(1999,212)$ genealogical investigation 
of oblichenie. On the psychological level, my avoidance of complete selfpublication (oblichenie) (i.e., showing all of my rough and unedited foreignlanguage thesis) constituted a cause for nedoverie. Once this nedoverie arose between this young man and me, he subjected me to regular tests and rituals of truth. When during a semi-competitive volleyball game, for instance, I fought over a point and (in his view) bent the rules, my gamesmanship evidenced that his nedoverie was justified and that deep down I was a duplicitous dissimulator: "we saw "the real" person during that rally!'

$(\mathrm{Ne})$ doverie marked the community boundary for this sceptical Old Believer: 'you can only trust Christians', he insisted. Since trust was limited to Christians he had no 'friends' outside the community of the faithful, only znakomy ('acquaintances'). But the young man was perhaps wise to be guarded about whom he trusted, for those who did were enrolled into an absolute and unequivocal relationship that expelled any vestige of doubt or disbelief. One of his most memorable remarks was: 'If you trust someone, he's always right' ('esli doveryaesh' komu-to, on vsegda prav'). The last word, 'right' particularly resonated in this context since prav connotes pravoslavie ('Orthodoxy'). A trusted person is an Orthodox person (who is an istinnyi ('true') Christian), and vice versa. Trusting someone was no small matter for this young man, for a trusted person became the measure by which the truth of the Orthodox community was authenticated: to the extent that an included person proved his trustworthiness, the community of faithful was proven right (Orthodox). In his slight wariness towards me, this young believer was trying to protect a truth régime within which trust, friendship, and Orthodoxy were bound together into an indissociable nexus. Trust for him was a principle of epistemological-psychological certainty that cancelled out the residual hermeneutic of suspicion that otherwise governed interactions with the rest of post-Soviet society. Trusted people were people you knew; they were knowable because they were Christians (whose insides are psychologically transparent), and by that very fact were true (Orthodox). The triadic relation of trust, psychological certainty, and religious truth formed the keystone of this young believer's epistemology. But during the Church schism the ontological grounds of Orthodoxy themselves were shaken and undermined. These fault-lines revealed how the psychological certainty and intersubjective confidence on the basis of which Christians could unproblematically have trusting relationship with each other depended on even more basic enactments of do-verie: the dynamics of before-faith and until-faith described above. 


\section{Trust after faith: the Russian Protestant ethic}

We have mapped out three living possibilities of doverie: 'trust' until-faith in Bolshoi Kamen'; 'trust' before-faith in Vladivostok; and the psychology of one young believer's nedoverie. There was a final option suggested by our initial lexical analysis, one that left behind the semantic association of anteriority that doverie conveyed, but instead took its cue from the simple quasi-philological observation that the stem (vera) could not have logically preceded the stem + prefix combination (doverie) (as in the translated Benveniste's unconvincing 'expansion' [rashirenie] of doverie to vera). From this common-sense doubt we can deduce another possible formula: first faith (vera), then trust (do-verie). If the Vladivostok lay 'patriots' occupied a position in which their trust came before and not from their faith; and if trust formed for the Bolshoi Kamen' revivalists the negative redoubt and threshold over which faith leapt into itself and, in so doing, consecrated trust from the perspective of its own completion - then the question remains whether there was any faction that exemplified the stance that faith precedes trust, that trust proceeds from faith: that generally moved in the direction from faith to trust.

In fact, both of these warring communities explicitly held the idea that trust would come from faith, not vice versa in the way that has been delineated thus far. This belief was one of the few things on which these two camps, so often at loggerheads, could both agree. Both groups continued to hope that the Old Belief would enable them to build trusting business relationships with others, in spite of the very limited gains that materialized in practice, only extending as far as certain embedded dispositions (such as the korennyi before-faith) checked the growth of a commonly shared trust. This was more of a discursively elaborated theory, rather than one that informed their practice.

Despite their deep political divergences, at the dawn of their unification in 1997 the Bolshoi Kamen' and Vladivostok communities were able to draft a joint declaration on the potential for Old Belief to provide a bulwark and model for post-Soviet Russia's economic modernization. Their address to Governor Nazdratenko, published in the regional newspaper, proclaimed that Russians needed to draw upon their dormant repertoire of spiritual resources, their faith, if they wanted to learn to trust each other in economic transactions:

The successful political and economic modernization of any state depends first of all on a correct reckoning of traditions and the particularities of 
national-historical experience [....] One would do well to remember that a market economy is effective only where the people have the cultural and psychological readiness for responsible and honest entrepreneurship. That's why the principles of Orthodoxy and in the first place, Old Belief's work ethic, have become a real issue for us, as it was a century ago.

In the first flush of the post-Soviet era, these Far Easterners' spiritualeconomic manifesto was influenced by Russian scholars who, themselves conscious of the Western formula that trust is the sine qua non of markets, postulated some possible Russian sources of 'trust' that might catalyse the virtuous circle of trusting autopoiesis that ignited Western capitalism. Such hypotheses began from Max Weber's premise that the necessary threshold of trust that kick-started this cycle in the West was a by-product of Protestant Christianity. The Weberian link between such a religion and such an economic ethic seemed strikingly present in one Russian historical phenomenon: Old Belief.

The communities that originally crystallized out of the Great raskol (schism) of Russian Orthodoxy distinguished themselves by those puritanical virtues of cooperative industriousness and thrift - so much so that, by the eve of the Russian revolution, educated Russians began to see their own version of a 'protestant ethic' in the wealthy 19th century Old Believers. From the perspective of his post-Revolutionary Parisian exile, the Old Believer industrialist Vladimir Ryabushinskii (2010) compared the inworldly asceticism of Old Belief with that described by Weber for the Calvinists. Already in 1909, not long after The Protestant Ethic was published, Serge Bulgakov, clearly inspired by the German sociologist, wrote: 'The research of Russian industry, in connection with the spiritual biographies and everyday conditions of the Russian pioneer-industrialists, would reveal the religious-ethical bases of the psychology of Russian industry. For example, the especially close link between Russian capitalism and Old Belief, to which belonged the representative of a whole bunch of giant Russian firms, is well known' (Bulgakov 1993, 331).

This distinguished line of Russian thought was revised and updated in the post-Soviet era with Danila Raskov's Ekonomicheskie Instituty Staroobryadchestva ('The Economical Institutions of Old Belief') (2012). Raskov claimed that, with its focus on Old Testament teachings and in its relationship to monetary interest, a theologically derived ethic of trust could be found within this Russian religious tradition. This ethic had an affinity with the pre-modern, personalistic and reputation-based capitalism, whose brief moment of florescence in the Russian metallurgical and textiles industries 
of the later 19th century was rapidly eclipsed by the influx of foreign capital and technological innovations - which, in turn, heralded the monopolistic and increasingly impersonal capitalism of the early 2 oth century. Raskov averred, however, that Old Belief definitely 'foreshadowed an alternative path of economic modernization' (Raskov 2012, 266), even though historical events took another course.This and related theories came to the attention of and were promoted by political organizations such as the Gaidar Forum (named in honour of the implementer of 'shock therapy'). At such events, Raskov has characterized the Old Believer as a species of 'homo credens': trusting man. ${ }^{21}$ In these arenas, the historical exemplar of pre-revolutionary Old Belief has been highlighted to expose the lack of theological foundations of trust in contemporary Russia, with the implicit corollary that an instrumentalization of Orthodox ideology might be good for business today. Both the Far Eastern revivalists and the 'patriots' espoused similar theories as those issuing from Russia's metropolitan intellectual elite during the 1990 .

At that time (the 1990s), the Weberian premise that a bedrock of faith was the missing ingredient in Russia's aborted 'transition' to a market economy became a given amongst outside commentators, who yearned to explain away the failure of liberalization to magic up markets and 'civil society' from the ruins of Soviet civilization. Francis Fukuyama's book Trust: the Social Virtues and the Creation of Prosperity (which was swiftly (mis)translated into Russian as Doverie) claimed that 'if the institutions of democracy and capitalism are to work properly, they must coexist with certain pre-modern cultural habits [...] which are based in habit rather than in rational calculation'. For Fukuyama, 'trust' is an 'expectation' that accordingly 'comes out of' (1995, 11) and is 'based on' (20) the cultural habits that take the form of implicit answers to 'deep "value" questions like the nature of God' - answers such as 'the view that pork is unclean or that cows are sacred' (34). Here, trust comes from shared faith: modern forms of economic exchange have been grafted onto religious-cultural roots. Fukuyama cites Weber's example of an American for whom trust in business transactions relies on a background of shared religious belonging: 'If I saw a farmer or a businessman not belonging to any Church at all, I wouldn't give him fifty cents. Why pay me, if he doesn't believe in anything?' (Weber, quoted in Fukuyama 1995, 46).

21 See 'Homo Credens: Ekonomika I Staroobryadchestvo' [Homo Credens: Economics and Old Belief] http://polit.ru/article/2014/o6/23/old_belief/"http://polit.ru/article/2014/o6/23/ old_belief/. 
A Vladivostok layman once expressed the same sentiment that faith should be taken as a surety for contract. When asked whether his copious beard might inspire mistrust in his business partner, he answered, 'How can someone mistrust me, a believer, for whom it is forbidden to steal, to cheat and to lie?" In practice, however, this layman's statement resounded with a certain irony: his security firm was suspected of all sorts of dodgy deals. From the perspective of a century's hindsight of the troubles that the Old Belief-as-protestant-ethic has had in practically realizing itself, Fukuyama's thesis appears to miss something crucial. While a tacit bedrock ('a culture') will partly over-determine and pre-empt how transactions will be perceived by actors (what Husserl called their 'fore-faith'), Fukuyama perhaps misled himself and his Russian readership by taking too uncritically the Weberian assumption that culture and religion are basically the same, that the religious-cultural basis of a society will be the indestructible substrate on which its modern institutions stand. For some post-Soviet adults of the 1990s, the tacit filter of 'fore-faith' by which they apprehended the world-as-already-thus-and-so was a late Soviet habitus. Fukuyama's theory was applied to a group of people whose accreted ethical habit, the culture-value-faith complex that evinces trust, resided not in the embodied and animated answers to questions about the nature of God, but on who is our friend and whom do we perceive as our enemy (Lenin's who-whom distinction); on a monological hermeneutic that projects every ambiguity as a threat (Stalinist suspicion); on the eventual advent of the svetlee budushchee ('bright future') (Young Pioneers propaganda); and other tenets of their Late Soviet upbringing. For this cohort, especially the provincial intelligentsia, it seemed also that the revolutions of 1991-1993 were their lives' defining, subjectivating 'events' (Humphrey 2008). It appears that no matter who one became after these events - including a faithful Christian - it was impossible to fully erase the indelible impression left by the side of the barricade on which one stood during this decisive conflict.

The culturalist angle, which sought a Russian protestant ethic to bracket businesses with 'religious adjectives', in practice produced a closed and suspicious community in Vladivostok. ${ }^{22}$ In the Russian Far East, shared faith could not be the background against which trust could flourish because theological doctrine, points of service, and liturgy became sites for continual disagreement, and for playing out the embedded value conflicts

22 On the growth of business with adjectives, including 'Orthodox', see Anton Oleinik, 2015, 'Arkhaizatsiya Politiki', https://www.vedomosti.ru/opinion/articles/2015/01/20/arhaizaciya -politiki. 
that stemmed from deeper, insoluble political cleavages (right-wing and left-wing, nationalist and cosmopolitan, ethno-racialist versus universalist).

While the Far Easterners admitted that they were far from living up to the ideal of the Old Belief ('we are far from the name of Christians here'), perhaps their botched experiment in building a 'Russian Protestant ethic' from scratch shines a somewhat negative light on the Weberian premise that religious values underpin economic success. Instead, one is drawn to Alexander Gerschenkron's counter-argument to the notion that certain theologically based ethics could explain the economic success of Old Believers, or Calvinists and Puritans for that matter. Gerschenkron argued that Old Believers' status as a persecuted minority probably provided 'sufficient impulse' (Gerschenkron 1970, 45) for any of the appurtenances of the capitalist spirit that the movement developed. But the corollary he drew from this conclusion was not that those persecuted minorities who become the best traders (those entrepreneurial 'Mercurian peoples' such as the Jews and Parsis (Slezkine 2004)) formed the cultural kernel out of which capitalism grew. Instead, the economist's point was basically a negative one: that Weber's link between religious adherence and economic success is doubtful; that the 'trust' that lubricates economic exchanges rarely comes from shared religious belonging by itself. He affirms instead Sir William Petty's opinion that 'trade is not fixed by any species of religion as such but rather...to the heterodox of the whole' (quoted in Gerschenkron 1970, 46) and commends Schumpeter's basic view 'that entrepreneurs are likely to spring forth from all layers and segments of society' - not only the religious ones $(47) \cdot{ }^{23}$

23 In Russia this search for the religious roots of economic modernization can yield amazingly contradictory results. For instance, Aleksandr Pyzhkov has shown in a recent book that the Old Belief contained in embryo not the kernel of capitalism, as Raskov asserts, but the shoots of Stalinism. In Korni Stalinskogo Bolshevizma (Roots of Stalinist Bolshevism), Pyzhkov relates how a large number of Stalin's closest associates hailed from Old Believer backgrounds. These included Kalinin, Bulganin, Ezhov, and Voroshilov, as well as Molotov and Malenkov, who formed an 'Old Believer party' (Pyzhkov 2015, 346), which resisted Krushchev's thaw after Stalin's death. Pyzhkov's book is not crackpot history: he details these Stalinist modernizers' bezpopovtsy (priestless Old Believer) links. One should also add that Boris Yeltsin came from the well-known Old Believer village of Butka in the Urals. Pyzhkov is not claiming that these Communists were Old Believers in any self-conscious or pious sense, but rather that they inherited a sectarian worldview and partisan ideology from this ancestry that underpinned their party factionalism. In such discussions the understanding of Old Belief as a tradition starts to lose its historical meaning and coherence, becoming unmoored from prayer, from its heroic martyrs and its stance against religious despotism, and instead becoming merely an byword for bigotry. Such histories shows the limitation of the less subtle forms of 'civilizational' thinking that reduce all the complexity of Weber's ideas to the bare notion of secularization. Nevertheless, it would 
But here we come up against the limit of applying to Russia the Weberian, Schumpterian, or whichever variant of the idea that there is some crosscultural substance, which is picked out conveniently by the English word 'trust', and that holds together and embeds commerce and contract the world over. This ethnography has shown how at least one Russian religious community (Bolshoi Kamen') had a limited system of exchange that was embedded in do-verie, but that this was closer to a Maussian gift exchange and was carried out between this world and the next, not as trade for profit. We saw instead that the Far Easterners' more ambitious aim to revive the religion in order to regenerate the moral economy of golden age Old Belief proved unrealizable. This plan perhaps failed because the prevailing postSoviet climate of violent and corrupt capitalism militated against it; an alternative explanation would be that religious value-ideas and the forms of do-verie convoked therefrom were not the main reason for 19th century Old Believers' economic success in the first place.

From our combined linguistic and ethnographic analysis we might conclude that when Western economists talk about 'trust' and Russians talk about doverie they are talking across each other. It is not therefore surprising that, like when dealing with the other recent exotic implantation into Russia (biznes), when Russians come up against the (in)différance of doverie to translation they make recourse to the loan translation trast (calqued 'trust'), which is perhaps a more faithful title for Fukuyama's book. The religion-economy link evoked by the English word 'trust' and enshrined in the inscription on the back of a dollar bill ('in God we trust') does not fully translate into Russian. Whereas King James and Luther bequeathed to the West translations that had it 'trust in the Lord', by some Derridean destiny Russia's Slavonic scripture exhorted the faithful 'to upovat' in God' ('have hope') (Romans 15:12; 2 Cor:1; John 5:45; Psalm 36).

\section{Bibliography}

Agamben, Giorgio, 2011. The Sacrament of Language. Translated by Adam Kotsko. Stanford: Stanford University Press.

Asad, Talal, 2015. Thinking About Tradition, Religion, and Politics in Egypt Today.

Critical Inquiry, 42(1), pp. 166-214.

be interesting to know how this book was received by Frolov and the 'patriots', whose 'rooted' style of thinking finds some echo in Pyzhkov's approach. How would their epistemic of origins stand up to scrutiny if they took not Kaganovich, but Ezhov and Malenkov as their paradigms? 
Benjamin, Walter, 1991. 20 Gesammelte Schriften [Collected Writings]. Edited by Rolf Tiedemann and Hermann Schweppenhäuser. Frankfurt am Main: Suhrkamp. Benveniste, Émile, 1969. Le Vocabulaire des institutions indo-européennes. Sommaires, tableau et index établis par Jean Lallot: Économie, parenté, société [The vocabulary of Indo-European institutions. Contents, tables and index by Jean Lallot: economy, kinship, society], Vol. 1. Paris: Éditions de minuit.

Benveniste, Émile, 1995. Slovar'Indoevropeyskikh Sotsial'nykh Terminov [Dictionary of Indo-European Social Terms]. Moskva: Progress.

Bourdieu, Pierre, 1990. The logic of practice. Stanford: Stanford University Press.

Bulgakov, Serge, 1993. Narodnoe Khozaistvo i Religionzoe Lichnosti [National Economy and Religious Personhood]. In Izbrannye Stat'i [Selected Articles]. T.2. Moskva: "Nauka", pp. 343-368

Derrida, Jacques, 1978. Cogito and the History of Madness. In Writing and Difference. Trans. A. Bass. London \& New York: Routledge, pp. 33-76

Gershenkron, Alexander, 1970. Europe in the Russian Mirror: Four Lectures in Economic History. Cambridge: Cambridge University Press Archive.

Glaeser, Andreas, 2011. Political Epistemics: The secret police, the opposition, and the end of East German socialism. Chicago: University of Chicago Press.

Foucault, Michel, 2014a. On the Government of the Living: Lectures at the Collège de France, 1979-1980. London: Palgrave Macmillan.

Foucault, Michel, 2014b. Wrong-doing, Truth-telling: The Function of Avowal in Justice. Chicago: University of Chicago Press.

Fukuyama, Francis, 1995. Trust: The social values and the creation of prosperity. New York: Free Press.

Heidegger, Martin, 1962. Being and Time. Trans. John Macquarrie and Edward Robinson. New York: Harper \& Row.

Heidegger, Martin, 1977. The Question Concerning Technology and Other Essays. New York: Harper Torchbooks.

Humphrey, Caroline, 2008. Reassembling individual subjects: Events and decisions in troubled times. Anthropological Theory, 8(4), pp. 357-380.

Husserl, Edmund, 2006. Späte Texte über Zeitkonstitution (1929-1934): Die CManuskripte [Later Texts on Time-constitution (1929-1934): The C-manuscript], Vol. 8. Berlin: Springer-Verlag.

Kharkhordin, Oleg, 1999. The Collective and the Individual in Russia: A Study of Practices. Berkeley:University of California Press.

Kordonskii, Simon G., 2008. Soslovnaya struktura post-sovetskoy Rossii [The Estate structure ofpost-SovietRussia]. Moskva: Institut Fonda Obshchestvennoe mnenie. Lévi-Strauss, Claude, 1969. The elementary structures of kinship. Boston: Beacon Press. Mauss, Marcel, 2002. The gift: The form and reason for exchange in archaic societies. London: Routledge. 
Mokienko, Valeriy M., 2005.v Glub' pogovorki: rasskazy o proiskhozhdenii krylatykh slov iobraznykh vyrazheniy [In the depths of proverbs: stories on the origins of catch phrases and figurative expressions]. Sankt-Peterburg: Avalon Azbuka-Klassika.

Morgan, Teresa, 2015. Roman Faith and Christian Faith: Pistis and Fides in the Early Roman Empire and Early Churches. Oxford: Oxford University Press.

Parthé, Kathleen F., 1992. Russian village prose: The radiant past. Princeton: Princeton University Press.

Pyzhkov, Aleksandr, 2015. Korni Stalinskogo Bolshevizma [The roots of Stalinist Bolshevism]. Moskva: Argumenty Nedeli.

Raskov, D., 2012. Ekonomicheskie Instituty Staroobryadchestvo [The Economic Institutions of Old Belief]. Sankt-Peterburg: Izd-vo S-Peterb un-ta.

Rogers, Douglas J., 2009. The Old Faith and the Russian Land: A Historical Ethnography OfEthics In The Urals. Ithaca: Cornell University Press.

Ruel, Malcolm, 1997. Christians as Believers. In Belief, ritual and the securing of life: reflective essays on a Bantu religion. Leiden: Brill.

Ryabushinskii, V.P., 2010. Staroobryadchestvo i Russkoe Religioznoe Chustv [Old Belief and Russian religious feelings]. Moskva: Most Kultury.

Slezkine, Yuri, 2004. The Jewish Century. Princeton: Princeton University Press.

Ssorin-Chaikov, Nikolai, 2003. The Social Life of the State in sub-Artic Siberia. Stanford: Stanford University Press.

Tolstoy, L.N., 1963. Sobranie sochineniyv 2o tomakh Tom:o8 Anna Karenina-Roman v vos'mi chastyakh. Avtor Lev Nikolaevich Tolstoy. Primechaniya BI Bursova i EG Babaeva [Collected works in 20volumes: 8 Anna Karenina - a novel in eightparts, author Lev Nikolaevich Tolstoy. Notes by BI Bursova \& EG Babaeva], Moskva: Gosudarstvennoe izdatel'stvo Khudozhestvennoy literatury.

Tolstoy, Leo, 2000. Anna Karenina. Trans. R. Pevear and L. Volokhonsky. London: Penguin.

Wagner, Roy, 1981. The invention of culture. Chicago: University of Chicago Press. Wittgenstein, Ludwig, 2010. Philosophical Investigations. London:John Wiley \& Sons. Yurchak, Alexei, 2013. If Lenin Were Alive Today He Would Know What To Do. In Irina Prokhorova (ed.), 199o: Russians Remember A Turning Point. London: Quercus, pp.14-34 



\title{
Trust, Chance and Disappointment
}

\author{
Real Estate Business in Russia’s Far East \\ Caroline Humphrey
}

Humphrey, Caroline (ed.), Trust and Mistrust in the Economies of the China-Russia Borderlands. Amsterdam: Amsterdam University Press, 2018

DOI: $10.5117 / 9789089649829 /$ HUMP

\begin{abstract}
This chapter examines the role of trust in buying and selling housing in Russia's Far East. It argues that 'trust' can be distinguished from 'reliance' by virtue of the fact that its breach calls forth different emotions: a feeling of betrayal as distinct from annoyance. Trust in this sense is not involved in the initial decision to purchase an apartment, which is attended by a host of other considerations, including attitudes toward chance and luck. But it briefly appears when a buyer reaches an agreement with a specific developer and starts to pay installments on the promise of a future apartment. The chapter examines the case of a Chinese-financed development company, showing how its attempts to create trust fail in the Russian market, and it discusses the phenomenon of 'cheated shareholders', whose anger at their betrayal by construction firms has given rise to a protest movement across Russia.
\end{abstract}

Keywords: real estate, chance (avos'), speculation, trust, 'cheated shareholders', public protest

Economists write that trust is central to economic life and many of their models assume that a rational agent will simply decide not to make a deal with a person held to be untrustworthy. In such a situation, potential trading is projected not to happen. However, ethnography disproves this idea. It is widely agreed that Russian public life is pervaded by mistrust, particularly in economic affairs (Oleinik 2005; Radaev 2004; Shlapentokh 2006; Safonova, Santha, and Sulyandziga this volume; Namsaraeva this volume). Furthermore, the mistrust of individuals, firms, and institutions in Russia is difficult to disentangle from persistent general uncertainty - the 
unpredictability that can be attributed alternatively to plunging exchange rates, sudden price hikes, or simply to 'the crisis', whether this refers to $1998,2004-5,2008-9$, or 2014-6. And yet economic activity goes on. Deals are still made, not only with persons from categories such as 'businessmen', 'foreigners', or 'the Chinese' - all held to be untrustworthy -, but also with specific undependable persons. As Russell Hardin (1992) and Partha Dasgupta (1988) observe, trust is a three-way relationship in which A trusts $\mathrm{B}$ to do some specific $\mathrm{X} ;{ }^{1}$ and yet, even when a customer is far from certain that $\mathrm{X}$ is exactly what $\mathrm{B}$ will do, he or she may well still make a deal. This chapter attempts to understand the kinds of knowledge, objects of concern, attitudes, and affects with which ordinary people engage in precarious transactions, taking the example of purchase of housing in Russia. I will suggest that trust is strictly temporary and time-specific within the overall process of a transaction. In the absence of reliable observance of the law, and amid widespread cheating (feared or real), non-professional economic actors who are first entering a speculative enterprise cannot trust someone they do not know. Rather, as I will show, they entertain a host of other heterogeneous considerations. People differ in whether they start off on the basis of mistrust, in the form of circumspection and suspicion, or whether they throw caution to the winds and go ahead based on the mere chance of success. However, once the lengthy process of purchase is under way, the buyer and developer have no option but to trust one another in the midst of a generally untrusting environment. If a relation of trust comes to grief, the betrayal, I argue, has different and stronger emotional repercussions than the reaction to mistakenly assuming the reliability of a partner. When trust is breached in the real estate business, these emotions have notable political consequences. The thwarted purchasers' anger spills over, blaming not only the developer who let them down but also the entire system - the state and its institutions - that enabled the situation of default to arise.

In their preface to a special issue of the journal HAU entitled 'Cultivating Uncertainty', Berthomé, Bonhomme, and Delaplace observe that 'opacity 
(considered as a formal property of some contexts) may proceed from various causes, such as inscrutable intentions, strategic dissimulation, double binds, or critical knowledge-gaps between participants', and that 'interactional uncertainty is not always reducible to accidental misunderstandings, but can also be a constitutive or "built-in" element of various social settings' (2011, 129-30). These observations are highly pertinent to real estate business in Russia, which is organized so as to create its own cloudiness on top of the general capriciousness of the economic environment. One way of appreciating this situation is by comparisons with other societies noted for a lack of trust between strangers. An example is the everyday economy of Ancient Greece, as documented by Steven Johnstone (2011). As Johnstone shows, the Greeks had little need for inter-personal trust: through legislation, the use of common measurements, accepted methods of deliberation in courts, self-declaration for tax purposes, agreed standards of honour, practices of collective liability, and so forth, the Greeks had devised many ways of reducing the scope for, and consequences of, default and trickery. In post-socialist Russia, by contrast, these measures are weak; when it is matter of transactions with Chinese firms from over the border, they are absent altogether. Nevertheless, as I shall argue, it is not 'blind trust' that people take recourse to when transacting with someone they judge to the untrustworthy.

The idea of 'speculation' can provide anthropological insight into such situations, taking speculation in its broadest sense to include all of the fore-images and anxieties that concern people when considering whether to make an investment involving a highly unpredictable outcome. Conceiving speculation in this way, ${ }^{2}$ anthropologists can address what makes such ventures a viable mode of action for a broad swath of the population not just the narrow category of professional financial risk-takers so ably analysed in the anthropological literature (Maurer 2006; Miyazaki 2006 and 2007; Riles 2004; Zaloom 2003). It will be argued that trust is one element in a spectrum of motivations involved in speculation, and for that reason it is worth defining 'trust' rather precisely as a moral expectation of known others (this will be discussed further below). Defined thus, trust has a minimal role in the initial speculative decision. However, this decision is far from all that needs to be taken into account. The transaction stretches

2 Russians themselves use the word spekulyatsiya ('speculation') negatively to refer to dishonest and/or illegal profit seeking deals - a hangover from the Soviet era when spekulyatsiya was a crime. When talking about themselves, they prefer these days to refer to 'investment' and risk (a direct borrowing of the English word). 
over time, from its imaginative preconditions to the playing out of the relationships it engenders, which in the case of Russian real estate can stretch over years. In the Russian housing market, the written Agreement (dogovor), obfuscating as it tends to be, not only ties previously unknown people (the purchaser and the building contractor) into an interactive relationship involving trust, but also in cases of difficulties and delays serves to transform these two positions into public roles with opposed social-political identities. This situation forces us to acknowledge that what is usually thought of as a 'thin' market relation between a seller and a buyer should instead be seen as an infinitely richer, longer-lasting, and dynamic 'attachment' (Savransky 2015), albeit one that can turn hostile. The identities of 'contractor' and 'purchaser' are more or less publicly elaborated by means of the website forums devoted to each housing development. When things go badly wrong, open-air demonstrations and raging faceto-face arguments about 'cheated' purchasers of housing lay bare, without resolving, conflicting attitudes regarding liabilities and responsibilities in the capitalist market.

The narratives of people in the process of acquiring property enable us to think about trust not only as a sociological reality but also as a cognitive category, one that plays discursive roles both for the Russian actors and for anthropology (Corsin Jiménez 2011). The unruly diversity of the populace requires a broad conceptualization of all that might be relevant, including 'outworn' and ridiculed ideas, as well as the heterogeneous mundane factors that people take into account. For this reason, I take up Martin Savransky's conception of the 'living economy' as an ecology, consisting of the patterns and densities by which beings of different kinds - persons, things, feelings, forms of knowledge, calculation, and anticipation - are bound to or untied from one another in late capitalism $(2015,1-2)$. This is an almost dizzyingly spacious conception, yet it is helpful when contemplating the multiplicity of the ideas and relations prevalent in speculation in real estate. Amongst these is the age-old Russian idea of avos' - a lackadaisical attitude toward chance - which operates as a kind of widespread ethos that has an affinity with popular speculation. Avos' is a familiar mode of contingency thinking and interaction with others that certain actors may find themselves adopting when deciding to make a purchase. It is a way of taking the plunge and ignoring the question of trustworthiness. However, other Russian citizens scorn avos', having absorbed since the 1990s the idea that the market demands strategy and calculation. In fact, the same people who pride themselves on their rationality are also likely disdain doveriye ('trust') as naïve, instead giving preference to ostorozhnost' 
('canny mistrust'), which is seen as self-protective vigilance. This attitude of suspicion, which registers both general uncertainty and the probability of a specific danger, does not in fact preclude economic action and may engender a certain cautious market virtuosity: indeed, mistrust can be both rational (Hardin 2004) and a virtue - see Introduction and Allard, Carey, and Renault (2016).

Thus, the market in Russia has become a battlefield not just of economic interests, but also of value judgements about the kinds of relations actors think they are engaged in. Avos' ('chance-it mentality') has become a particular object of dispute, largely because it has come to be linked with the identity of 'cheated' contract holders/speculators, and this colours it affectively and evokes sharp reactions. These unfortunate people are a significantly vocal, restive, and oppositional presence in Russian public life; they write complaint letters, brief the media, and stage sit-ins and hunger strikes. The Internet has become a crucial medium for debating the locus of responsibility for the whole phenomenon of these tens of thousands of 'cheated' people. The finger of blame shifts from the purchasers themselves, to development companies, municipal officials, state agencies, the government, and the President of Russia himself. Other people's pleas or self-justifications are hardly ever taken at face value. Was it not in Russia after all that the poet wrote, 'A thought once uttered is a lie'? ${ }^{3}$ To summarize, real estate has become an arena of high, yet contested, emotions, and one of its most potent charging energies is the feeling of betrayal at being let down in a situation in which trust has been brought into play.

\section{Attachment to the house}

In any capitalist environment, the house materializes opposing orders of value. On the one hand, it is someone's home: here is precious privacy, hopes, memories, and the familiarity of intimate relations. Its existence is the material and aesthetic effect of a particular way of life, and that is how visitors immediately sense its personal atmosphere. On the other hand, the house is an alienated commercial thing. Measured abstractly by price per square metre, it is the plaything of fortuitous economic and political events and all of the many non-human forces that might affect its monetary value. There is also the plain need for somewhere to live. 
In Russia, the necessity for people themselves to deal with this need suddenly became acute with the ending of the Soviet allocation of almost costless housing as a right, usually by the place of work. Now, bitterness attends the thoughts that one's meagre savings must meet rising prices, that commercial interests or sequestration for one's debts might snatch one's home from one's hands, or that rich people have been able to buy strings of apartments as an investment. Yet these antimonies meet in every experience of the housing market.

The kind of home that will be the concern of this paper is an apartment in a large block of flats, this being the typical residence of the vast majority of Russians. These days there is housing crisis in the country. The old Soviet blocks are crumbling, and there is a massive, pent-up desire among younger, educated, and employed people to move out of the crowded accommodation shared with parents and other relatives, or from shabby expensively rented flats, into their own, newly built, clean and modern homes (Zaviska 2012). The cities have been overwhelmed by streams of incomers from rural areas and small towns following the collapse of Soviet economic institutions. To meet this demand, every Russian city has experienced a construction boom. Rows of high-rise blocks stand like ramparts, forming whole quarters and new districts, some more attractively arranged as elite communities, others bleakly rising halffinished among the ruins of former industries and surrounded by muddy and yet-to-be-built roads. Fortunes have been made by some developers; others - and sometimes the same ones - go bankrupt one after another, only to perhaps appear again under another name (see Namsaraeva, this volume). A Russian dom ('house') may contains hundreds of one, two, and three-room kvartira ('apartments'). It is one of these - with its own layout, view, and surroundings - that is the desired goal, the home to be. How, though, to acquire one?

\section{The ordinary speculator in Russia's housing market}

Let me first describe the volatile conditions with which the buyer has to contend (see also Humphrey, in press). In the housing boom of 2000 to 2007 , the market prices of re-sale apartments skyrocketed by 436 percent while new build prices rose by 362 percent. Since then, prices have zigzagged up and down. Recently (2014-2017), despite yet another economic crisis, increased costs have meant that house prices continued to rise by around 1 percent per quarter in many areas of the country and prices per square metre in Moscow 
and St Petersburg were still very high by the standards of prosperous world cities. ${ }^{4}$ Russian critical opinion attributes these extraordinary prices to monopolies in land and construction markets set up by 'mafiosi-municipal clans', which enable certain well-connected speculators to amass property in housing, while competitors are kept out of the market, new construction is slowed down, and prices kept artificially high. ${ }^{5}$ Though the massive new supply began to bring prices down, especially in Moscow, nevertheless there was a burst of buying activity in 2014-15. According to Russian real estate specialists, the surge was most probably because of the Ukraine crisis. 'Demand has grown significantly - it is clear that buyers are seeking to get rid of the rouble,' commented the portal 'Mir Kvartir' (The World of Apartments). 'In part this is an emotional reaction, the anxiety caused by noticeable weakening of the Russian currency', as one realtor put it. ${ }^{6}$ Russia's key interest rate rose six times during 2014 in an attempt to counteract the instability caused by high inflation and the EU sanctions against Russia, but fell again during 2015. In 2016, prices for new houses were definitely on the downturn. Still, whatever these swings, ordinary people look at property as a safer haven for their money than banks ('They'll always find some way to extract money out of you,' as I was told). Until recently, venturing into property had been encouraged by the expansion of the mortgage market to around a quarter of all sales in the country, but the volatile interest rate has turned people away from mortgages. ${ }^{7}$ In any case, many older Russians dislike the whole idea of being tied down by mortgage payments for years into the future, which they call kabala ('debt bondage') (Zaviska 2012). They would prefer to scrimp and save, or take a large personal loan, in order to pay outright as quickly as possible and become the sole owner of the property. In short, although demand has fallen there are still plenty of purchasers. Surveying a turbulent financial landscape, most people decide to jump into the market with their own money, or with credit borrowed on their own account, and quite often this money is cash: wads of notes in a briefcase.

4 See 'Analysis of Russia Residential Property Market' (June 2014 and September 2017) with data provided by the Federal State Statistics Service. http://www.globalpropertyguide.com/ real-estate-house-prices/R\#russia.

5 Boris Nemtsov writing in 2008. http://mirror573.graniru.info/Politics/Russia/m.133263.html.

6 Quoted in http://www.globalpropertyguide.com/Europe/Russia/Price-History.

7 The Russian government has tried to support mortgage purchases through lending support programmes. It also provides a lump sum to mothers of three or more children ('maternal capital'), which might in principle be used to provide the first instalment on a home. However, the ratio of mortgages to GDP rate in Russia is still (2015) by far the lowest in Europe at 3.5 percent. In the Netherlands, it is 108 percent. http://www.hypo.org/Content/Default.asp?PageID=414. 
It would seem that the 'attachment to the house' would be very different for the investor with an eye to re-sale or rental value than for the person who is interested in the apartment as a place to live. Except at the two extremes, however, it is difficult to make this distinction in practice. Many middle-class Russians buy extra apartments for a mixture of reasons, and these can change according to circumstances: 'Perhaps my daughter will live there,' people might say, or 'It's the best way to preserve my money. I may need to sell it when I move to Moscow and have to buy something more expensive', or 'It's for my old age, but I'll rent it out now'. Nevertheless, around 70 percent of apartments are bought to live in, as the sole dwelling of the purchaser. ${ }^{8}$ The risks are indeed great for these people.

Most of the pitfalls arise from the most prevalent form of purchase, which is called dolevoe stroitel'stvo ('shared construction'). ${ }^{9}$ The client negotiates directly with the developer to buy an apartment 'off plan', i.e. when the building exists only on paper, often even before there is a kotlovan ('foundation-pit') on the site. The idea is that the buyers join with the company in the venture of building the apartment block, and once it is completed each purchaser will acquire a dolya ('share') in it. The prices of apartments-to-be are significantly lower than those of finished dwellings: only one third in some cases. This why well over go percent of purchases of new build housing are through shared construction schemes in Russia; low salaries and widespread household indebtedness mean that most buyers cannot afford any other method. Construction companies, meanwhile, especially small ones, have to rely on the incoming payments to cover their costs, because banks are reluctant to give loans for such a risky business. This situation is what makes the deal speculative in several ways: the dol'shchik ('buyer') is betting first, that the notional apartment will be built, second, that it will be handed over to him as his property, and third - the usual speculative bet -, that its market price will rise. Meanwhile, the zastroishchik ('developer') is speculating that the incoming payments from buyers will both cover the costs of construction and make a profit. With the unpredictable seesawing of the value of the rouble, interest rates, and oil prices, this is a gamble indeed for even the largest companies. Since a developer must make payments before a scheme can be legally advertised

8 This was the view of a developer in Vladivostok in 2015. The proportion is different in other cities, especially Moscow where the purchase of housing for investment is more prevalent.

9 This is different from the 'equity sharing' or 'housing equity partnership' (HEP) schemes designed to assist in the acquisition of low-cost housing in Western countries. Unlike the latter, it does not involve public subsidies, mixed purchase-lease arrangements, or legal caps on payments. 
for sale - for the purchase or rent of the site, planning permission, payments to sub-contractors to order materials, etc. - a new development is often financed by payments made for an earlier one, which itself may still not be finished. In the scramble for ready cash as bills become due (and for money to put in their own pockets), developers acquire new sites to garner more income, a process that can be repeated again and again. Any halt in these onward payments may cause the company to go bankrupt and building to cease down the line, which is why Russians call them pyramid schemes. In the first half of 2016 almost 1,60o building contractors went bankrupt in Russia, creating a new burst of 45,000 'cheated dol'shchiki' (Torocheshnikova 2016). In effect, the dol'shchik and the zastroishchik are speculating on one another, amongst other imponderables. The dol'shchik is gambling on the financial soundness and honesty of the zastroishchik, and the latter is betting that his schemes will attract sufficient buyers who will actually pay up, cover his costs, and allow him to make a profit.

This is a Russian comment on the buyer's situation:

'De-facto' the apartment does not exist, 'de-jure' it exists on paper - but even then, only in the future. In other words, the apartments are virtual, bits of a castle in the air, but the money you pay out is real. And when will the dol'shchik receive his share? Obviously, when the house is built. While the house is being constructed he does not have a share, only the right to receive a share in the future. ${ }^{10}$

These virtual apartments-to-be often themselves become means of payment: the developer may pay his sub-contractors for their work with a number of future flats, and he may even pay himself with them (investing his own money in the block for the right to acquire a future share in it himself). Significantly, the zastroishchik also frequently use apartments to pay the municipal authorities. This can be in addition to, or one of, the 'administrative rents' exacted during completion of the bureaucratic procedures (acquiring the land; registering the contract; obtaining safety, fire, hygiene, and cadastral planning permissions; registering the building itself; and so forth) that so frequently hold up the final handover to clients. Potential buyers are warned to check that their contractor has made some such compact with the officials, although it is acknowledged this is difficult given the secrecy of such divvying-up arrangements. Otherwise, the clients'

10 'Kto takoi dol'shchik', anonymous comment on property forum, 2014. http://www.mos-kva. ru/dolschik.php. 
dream homes are likely to be frozen and become a dolgostroi ('delay-build'), often for years. ${ }^{11}$

Venturing into this quagmire, purchasers rarely seem to start with what economists might assume would be their priority: checking on the credentials of the developer. This is the account of Yevgenii, a young professional who ten years ago sold his apartment in Irkutsk when he moved to Moscow for a new job, but lost his money when he went into a 'shared construction' scheme. When asked, 'The organization that you paid into, did it have a good reputation? What was the main reason you trusted it?', Yevgenii replied:

There was no reason - for me, it wasn't a question of trust. I first looked at the place that I liked, the house itself, the whole area around, the transport to the city, and the price. I saw a house going up and I wondered if I could get a flat there and so I found the company on that basis. The firm had been in existence for some years, had built other houses, and people had received their flats there. Still, I knew it was risky. I understood that the firm had been set up more or less on the principle of the pyramid - but, ha ha, I hoped that the firm would collapse only after I received my flat.

It is evident from this and many other accounts from dol'shchiki, that many people 'speculate' while sharing the general mistrust in building firms. Yevgenii understood that the company was not to be relied upon - but he still hoped that he had seized the right moment.

Well, today, having lived through this sad story, of course I can't say that it was a rational decision. It was on the same level of rationality as for example taking your hard-earned income and putting it on the horses or into the casino in the hope of winning. But like any person, I willingly convinced myself of what I wanted to believe.

Another way of putting this is that Yevgenii was betting on his own hopeful intuition about timing. This recalls Olav Guenther's description of traders in Central Asian borderlands, who operate by spotting the exact moment and place in which they can make a killing. Guenther calls this kind of operation a 'Kairos economy' - Kairos being the Greek god of the opportune moment - and he argues that such economies involve no long-term planning and little calculation. 'Kairos cannot be part of a plan but has to be a part of the disposition of the actor' (Guenther, n.d., my 
emphasis). To put the question of dispositions into a comparative capitalist context, we can note Miyazaki's discussion (2007) of the distinction made by Japanese financiers between what they see as the 'rational', systemically 'helpful' operation of arbitrage and the disparaged 'intuition' involved in speculation. Even though the practice of arbitrage was actually no less risky than speculation, financiers were determined to identify with arbitrage's theoretical and assumed absence of risk. Their professional disposition was to reject the notion that they might go down the 'easy', 'default' path of speculation, which relied on intuition and impulse rather than on calculation. In principle, Russian purchasers can also make a choice: there is the option of buying an already-built apartment outright, though the higher prices make this ne real'no ('unrealistic') for any but the very prosperous. However, a widespread disposition is not to avoid risk, but rather to accept it.

In the ardent desire for a home a great variety of factors are taken into account, and when a buyer prioritizes one of these the other considerations retreat into the background. For Yevgenii, it was that the low price of the flat corresponded to my monthly income'. Rather than looking at various prices as informational signs about the state of the market, his consideration was his own circumstances now and projected into the future - the thought that, since prices were rising steeply at the time, he would have to buy immediately or forever give up the thought of being able to acquire an apartment. The temporal coincidence was one that crossed his own financial situation with his intuition (mistaken, as it happened) that the pyramid would not collapse. The opportune moment was not general - it was the right moment for him. Further accounts reveal that purchasers can become fixated on other elements, to which they devote months of searching. For one man, it was the location of the apartment: this had to be on the desirable side of Moscow, no more than ten minutes' walk from a Metro station, distant from industry, with windows facing south, on a floor above the $3 \mathrm{rd}$, and having a view of the countryside. In Vladivostok, buyers agonized over the position of a house in relation to the sea winds, or its potentially intermittent electricity supply, or its likelihood of being enveloped in fog, or the prevalence of landslides at the site. Many obsessed about traffic jams and whether they would be able to get to and from work. Others focused on promised schools and/or shops, or car parking slots, or bus routes to the new development, and the probability/improbability that the municipality would actually supply these services. For some, the character of the other people buying into the house was important: would they be lowly folk in tiny one-room flats, or would it include some 
Figure 12 A young couple negotiates a purchase in the 'Eastern Breeze' development, Vladivostok, 2013

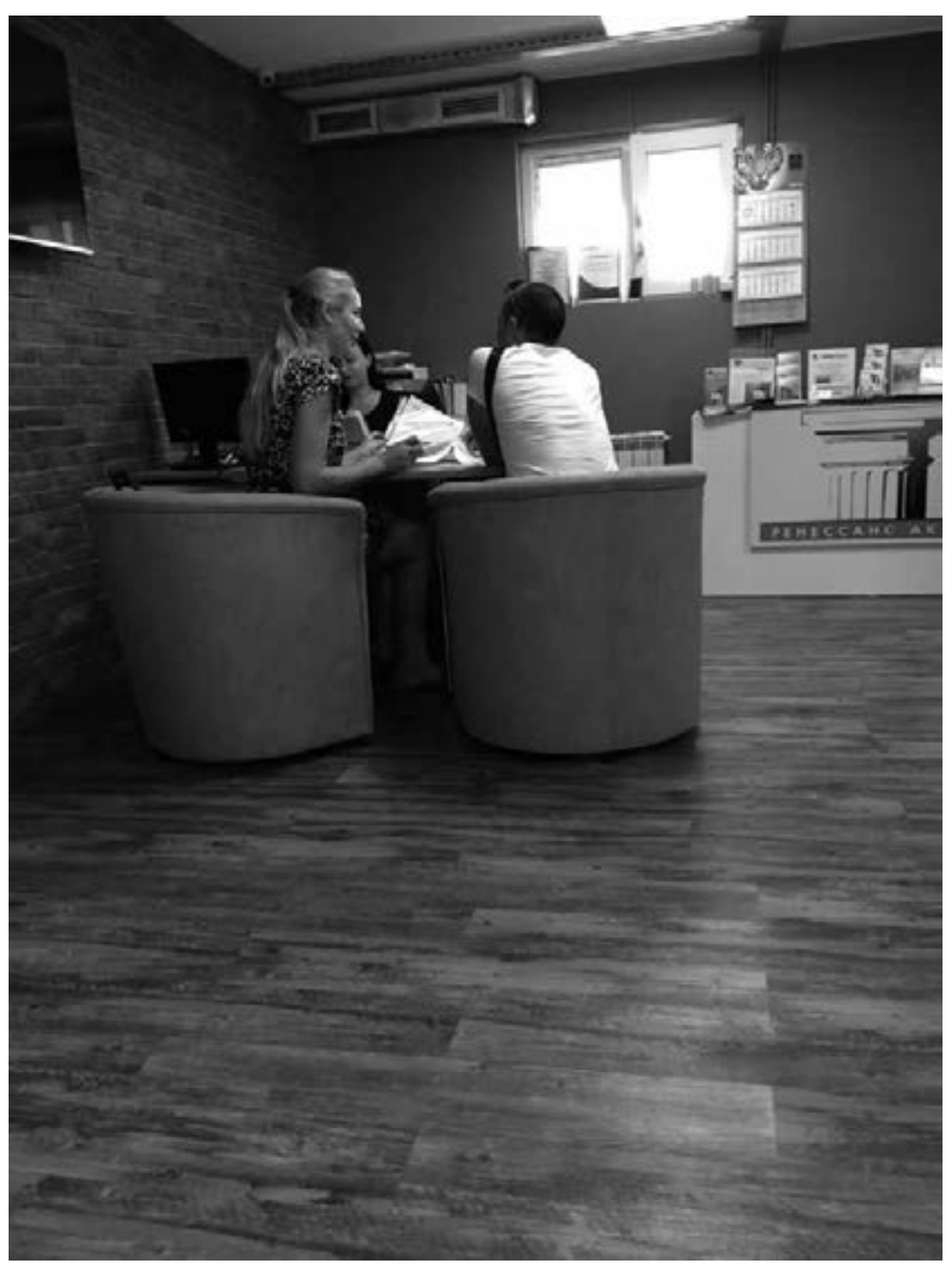

Photo: C. Humphrey 
Figure 13 The 'Eastern Breeze' complex, Vladivostok, 2013

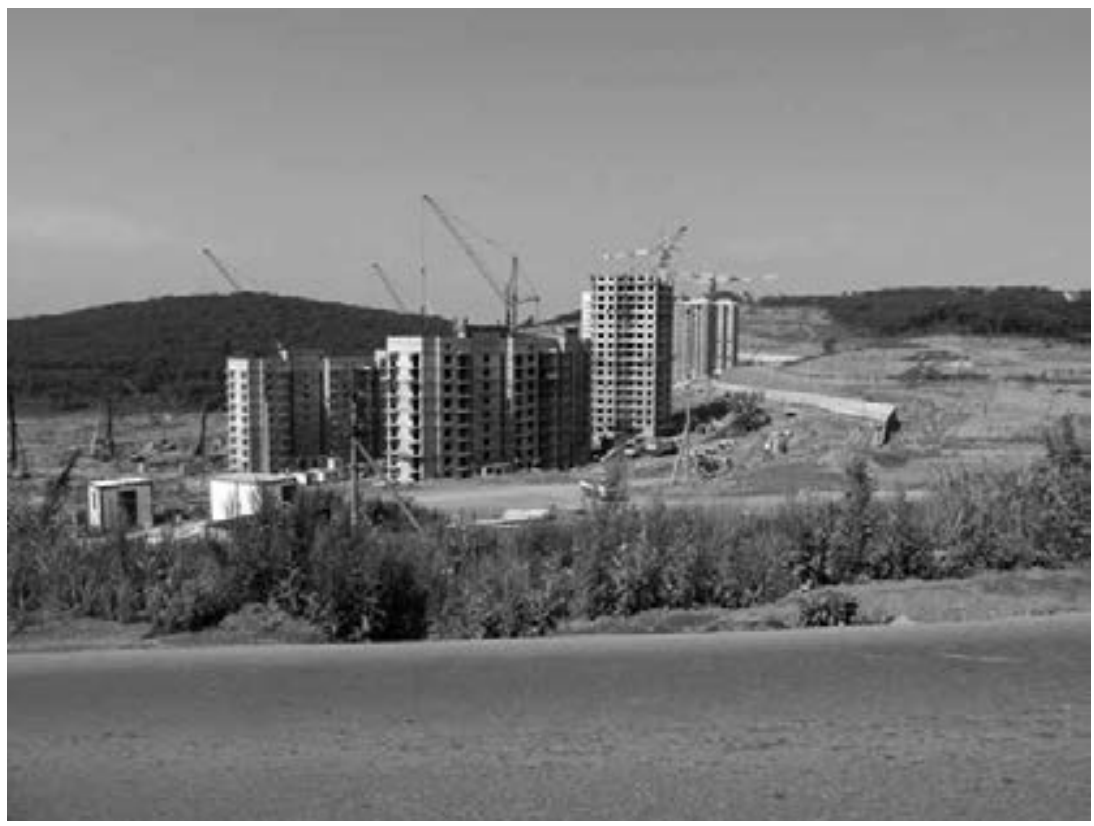

Photo: C. Humphrey

celebrities who would raise the tone and increase the likelihood of the house being built? Many purchasers also take seriously the lucky (e.g., 7) and unlucky (e.g., 13) numbers of the floor on which the flat-to-be is situated (Antipov and Pokryshevskaya 2015). The reputation of the developer comes somewhere among these concerns, but relatively few people seem to regard it as decisive. An economist might assume that such multifarious considerations are the market and should immediately reflect in the prices of apartments, but in practice in the inelastic and idiosyncratic Russian real estate business this tends not to happen. ${ }^{12}$ As for the purchasers, to judge from their conversations on online forums, it is as though price could never be a summing up of abstract 'demand', but instead can only be seen as one factor among others specific to each buyer. Thus, speculation is an action that takes place amid a particular concatenation of 'attachments' with things in the world, each of these appearing as separate variables, chaotically unrelated to one another.

12 The exception is ground floor apartments, which tend to be cheaper because their disadvantages (security, noise, lack of a view, etc.) are so generally recognized. 
Avos'

Yevgenii's nadezhda ('enabling hope') can be better understood in light of the idea of attachment. This was not general hopefulness in the benign workings of global capitalism or in the improvement of the Russian economy. Rather, it was his relation to a specific housing opportunity. As Miyazaki (2006) argues, in a capitalist context a hopeful relation is always situated, and hence is not one (universal) hope but many kinds of hope. This suggestion allows anthropological comparison between the ideas of social theorists and the various concepts of economic actors. A similar point has been made by David Graeber when writing about 'fortune' and luck'. He observes that concepts such as mana, sakti, baraka, and orenda might best be considered 'grappling with the same ambiguities and antimonies of temporal existence that all humans, even social theorists, have to confront in one form or another' $(2012,25)$. I draw attention to the Russian avos' as another such concept. Avos' expresses the hopeful idea that 'it might work out for me', with a low degree of probability. The subject is understood to be is present in a world of happenings, objects, and processes over which she has no control. Her own actions partake of the same fortuity, since whether they achieve a desired goal is subject to the same maverick conditions. Calculating in terms of probability is foreign to avos'.

It might be tempting to attribute the avos'attitude to the lasting reach of Soviet governmentalism, which took so many life decisions out of the hands of citizens and imposed its own (often seemingly arbitrary) regulations over practically everything. But avos' is better understood through a longer genealogy. Centuries ago it entered the stream of Russian vernacular as the alleged disposition of the 'passive' and 'careless' muzhik ('peasant') (e.g., in the folk sayings, 'the Russian muzhik even sows his corn na avos' [on chance]', or 'the Cossak mounts his horse na avos', and the horse na avos' gives him a kick'). The idea became a sacralised abstraction, both in folk sayings ('avos' is the Russian god') and in literature (Pushkin called avos' the 'Russian shibboleth'). In Soviet times, the poet Voznesensky wrote, 'When Ave Maria is powerless, there breathes through us, through atheistic Russia, supernatural Avos.,' ${ }^{13}$ With this supernatural 'breathing through', the responsible subject almost seems to disappear. Avos' can be associated with the passive reflexive verbs that are so pervasive in the Russian language, verbs that express the idea of something happening of its own accord, often to itself (e.g., sbudet'sya, 'it will be realized'). Such usages often omit a noun 
subject. Yet etymologically avos' is an abbreviation of $A$ vot, seichas ('There it is, right now'). This buried visuality in the philology suggests that the avos' disposition implies a certain 'speculative' subject, one that looks around for a chance; in other words, avos' suggests a perspective internal to itself that one can adopt and use as a launching pad for a certain kind of chancy action.

The appropriate attitude with which to bear the unpredictability of $a v o s^{\prime}$ is terpenie ('endurance'), the highly valued patient acceptance of hardships and misfortune. ${ }^{14}$ Terpenie implies waiting, either with hope or without it, but in any case it is not totally passive: it requires conscious acceptance and moral fortitude. Terpenie is ennobled by the religious value of smirenie, which could be translated as 'humility', or the patient acceptance of one's fate achieved through a peaceful loving attitude toward other beings (Gladkova 2004, 5). Both avos' and terpenie presume that one is living in a potentially hostile world 'which cannot be rationally controlled' (Wierzbicka 1992, 435). Furthermore, the constant reiteration, in the case of almost any misfortune, of the idea that one has been cheated (Shevchenko 2002) indicates the suspicion that malignant intentions roam through this world, which can only be dealt with by putting up with disappointment and treacherous other people. ${ }^{15}$ Few situations could more require terpenie than the anxious waiting during the time between signing up to buy an apartment and actually getting one's hands on it. This wait is beset with, and depends on, a thicket of documents, which generate what Olivier Allard (2012) describes as 'bureaucratic anxiety'. The papers may be technically legal, pretence-legal, or legal substitutes, but in every case they hide the likely outcomes in deceptive verbiage. Yet, as the following section will recount, this very opacity is what conjures up a certain evanescent trust as a condition for proceeding.

\section{Trust and the dogovor ('Agreement')}

I have suggested that making opportunistic economic decision amid uncertainty involves diverse motives and concerns, but not trust. Of course, such a statement depends on how 'trust' is defined. Amongst the numerous

14 This is seen for example in Dobrolyubov's sentence, 'The majority of people when trapped under the domination of a tyrant prefer simply to bear with (terpet') it, in the blind hope that avos' the circumstances will change', quoted in Gladkova $(2004,5)$.

15 Terpenie is a positive value: single women looking for partners on websites often advertise terpimy (something more than 'tolerant') as one of their desirable qualities, indicating not just an attitude of acceptance of other people, but calmly bearing with their probable bad behaviour (Gladkova 2004, 9-10). 
delineations of the idea (see Introduction and Ryzhova, this volume), I have chosen to use that of the philosopher Katherine Hawley (2014) because it enables me to discuss the social outcomes of the difference between reliance (that something will happen as expected, that someone will do what they usually do) and trust, which involves gauging another's obligation, sincerity, or commitment. I shall suggest that breaches of this kind of trust generate emotional reactions that can be the springboard for public action.

Trustworthiness, Hawley states, is a virtue. It is something we aspire to. Thus, trust has a normative dimension, which is not the case with reliance. This can be seen from the different responses to a breach. If I have mistakenly relied on you to do something you usually do, but did not do on this occasion, I would feel disappointment or annoyance; if I have mistakenly trusted a person, I feel something different: betrayal or hurt. Trust involves the idea that the other has an obligation or commitment to accomplish the given act. Hawley similarly argues that distrust is not the mere absence of trust: it involves something stronger: the expectation that a commitment will not be fulfilled $(2014,1)$. Some advantages of this conception of trust are that it copes equally well with trust and distrust, allows the possibility of trust in strangers of whom one knows little (Hardin 2002,5 ), and yet posits both the one giving and the one receiving trust/ distrust as moral persons inhabiting the same normative world. Hawley's formulation is especially useful for considering a generally sceptical and pessimistic market situation, since it does not require the person giving trust to impute benign motivations to the one who is trusted or to expect him to 'encapsulate one's interests' (Hardin 1992).

To return to Russian real estate: clearly Hawley's kind of trust is not involved in the initial decision to buy, when the developer is only one factor amongst other unknowns. But trust becomes an issue during the process of making an agreement. Hawley's discussion enables us to distinguish reliance on a document of agreement from trust in a person, the zastroishchik ('building contractor'), who is held to have an obligation to fulfil it. Trust comes into view as soon as the purchaser and contractor sign a preliminary soglashenie o namereniyakh ('agreement of intentions'). This document has no legal status and is not a thing to be relied upon. Indeed, advice websites warn that preliminary agreements are one of the 'grey schemes' by which unscrupulous contractors extract money from the unwary and then fail to fulfil their side of the bargain. With such an agreement, the zastroishchik promises to provide only a flat in the future, not any particular one; since all of the apartments remain his property there is nothing to prevent him from making similar agreements with 
other purchasers for the same item. ${ }^{16}$ No sensible person would rely on this document in itself, and yet a certain trust has appeared - and may be all there is to go on - since an agreement of intentions signals a moral obligation. Before signing a buyer will usually have made several visits to the contractor's sales office, talked with a representative, looked them in the eye, and made a judgement about their human trustworthiness. This is a mutual assessment, since the purchaser agrees to hand over payments but is not required to provide legal proof of his or her creditworthiness when signing.

There then ensues a period of further steps: the buyer pays to reserve a particular flat, gathers the legal and financial documents proving that she qualifies to sign the proper Dogovor ('Agreement'), has them notarized, waits for the contractor to issue the Dogovor, books a date for its official registration with the Rossreestr, makes further payments according to the specifications, bides her time while the building is completed (during which years can tick by), hangs on even when the block stands ready for occupation while it is checked and certified by various inspectors, and finally waits for the municipal authorities to give permission for it to be $s$ dan (handed over) as private property. As for the Dogovor that regulates these steps and their timing, delays in construction frequently make revisions necessary, which buyers reluctantly have to accept. Furthermore, although online websites provide model samples of dogovor that comply with the latest law, all large construction companies have their own legal departments that draw up their own variants (including, of course, loopholes). Yet, most purchasers do not take legal advice, which is expensive, nor do they scrutinise carefully the text of the paper in their hands - one word or omission in which can spell their doom. ${ }^{17}$ The managing partner of the realtor Spencer Estate commented:

It is common to find sad cases of avos'. When buying flats with obviously suspect documents but a price well below the market rate a considerable proportion of our citizens continue with arrangements, even though any foreigner would have long ago fled from such fishy schemes. Sometimes when searching for a flat for clients I have to push them away almost by

16 http://podolskrn.ru/book/export/html/4918.

17 'Hoping "na avos'" is based on the legal illiteracy of the clients and their absolute unwillingness to get involved in the legal aspects of real estate. [...] They skim through the papers and sign without attending to the details,' said Mariya Litinetskaya, director of the real estate agency Metrium Group. http://riarealty.ru/affordabletrends_analisis/20130809/401091712.html. 
force from dubious offers that seem extremely profitable. Sometimes they even get angry with me. ${ }^{18}$

The contractor will try to get away with whatever he can, and to conceal behind the written obligation the extent or way in which he is insured and subject to penalties. But to the purchaser the Dogovor is something simpler. It is primarily an interpersonal promise, since the extent to which its legally binding nature could ever be realized is a matter of doubt and conjecture. ${ }^{19}$ This document does one thing, though: it establishes the client's identity as a dol'shchik, the co-constructor and owner-to-be of a share in the building. As a paying dol'shchik, the person feels entitled to feel indignant, harass the constructor with phone calls, join online groups of other buyers in the apartment block, share photos of faulty elements in the building process, or join with others to bewail the discovery that a rubbish dump is to be located right under their windows.

It is as 'cheated dol'shchik' that the status has flowered in public. The obmanutye dol'shchiki are those who have paid and hold contracts, but whose apartments lie uncompleted or, if built, not handed over to them. There are tens of thousands of these unfortunate people in Russia; they exist in every city and, unusually for the country's normally quiescent citizenry, many of them have joined strident movements of protest (Humphrey, in press). Their anger is based, I suggest, not so much on plain disappointment that their risky decision did not pan out - for which terpenie would be the common reaction - but on the sense of betrayal that a promise had not been honoured. Betrayal (obman, izmena) demands a response: vengeance or punishment.

From an economic point of view, this puts the thwarted buyers into a double bind. On the one hand, they want to hit out at the errant developer, to get the authorities to force him to finish the building, or to pay high penalties as well as return their money, and they invoke 'moral harm' as a legal concept that could entitle them to compensation for their years of useless waiting. ${ }^{20} \mathrm{On}$ the other hand, these very actions greatly increase

18 http://riarealty.ru/affordabletrends_analisis/20130809/401091712.html.

19 See Torocheshnikova (2016) on the slim chance of getting adequate recompense in the courts, even after new legislation aimed at supporting clients.

20 After the passing of law 214-FZ in 2004, a legally registered Dogovor gives 'cheated dol'shchiki' the right to sue the company for the return of their money. However, many signed Agreements are not in accord with this law, rendering their rights insecure. In order to sue, clients must be registered as 'cheated dol'shchiki', which means they have to fulfil various bureaucratic criteria not attainable by the majority of claimants (http://www.m24.ru/articles/80962).This situation, 
the chance that the developer will simply declare bankruptcy - or flee Russia, taking the money with him - in which case the dol'shchiki have almost no chance of getting either their apartments or their money back. The zastroishchiki understand this dilemma all too well: firms have been known to pressure their dol'shchiki, telling them that public outcry and 'false accusations' will ruin the firm's reputation, making it impossible to garner the future sales on which the completion of the buyers' flats depend.

\section{The non-coincidence of reliability and trust}

As we have seen, a reputation for reliability is not the first priority for either developers or buyers at the 'quick buck' end of the market. However, some companies do have a longer-term view, and it is instructive to see how they manage relations with their dol'shchiki. The Armada group in Vladivostok is an example, showing that the relatively successful establishment of a reputation for reliability does not imply the presence of either personal or public trust. Armada has several developments in the city, headed by three high-profile apartment blocks called 'Scarlet Sails'. The firm has had to overcome several disadvantages. First, it is known to be 'Chinese', with Russian podstavnye litsa ('figureheads') as its public face. Online forums record clients' scepticism that the declared 49 percent reflects the true degree of Chinese ownership. It was not so much the camouflage that was an issue - this being seen as probably forced on the company - but that until very recently in popular opinion 'Chinese business' meant only one thing: shoddy quality. The town council decided that the Scarlet Sails apartments advertised by Armada as elite 'business class' were standard products and would turn out to be only premium or 'ekonom klass' and that it would be better for the company to choose another, less resoundingly romantic name for them. ${ }^{21}$ Hostile media in Vladivostok then declared the development to have a 'bad name' on the grounds that a scandalously corrupt scheme in Moscow also called Scarlet Sails had treated its foreign construction workers harshly, and many had died and been secretly buried on the site..$^{22}$ Perhaps not entirely by accident, potential buyers into the

\footnotetext{
as well as the high legal costs and uncertainty of the outcome, deter many from having recourse to the courts. Legal redress is best obtained by group action, led by activists prepared to tackle the necessary bureaucratic-legal legwork.

21 http://www.zrpress.ru/business/vladivostok_04.12.2012_58133_vladivostok-poluchit-svoialye-parusa.html.

22 http://www.primmarketing.ru/news/2013/11/14/alye-parusa/68580/.
} 
Vladivostok blocks soon began to wonder about former graveyards on Egersheld, the narrow peninsula being dug up for the building of Scarlet Sails. What heroes, ancestors, or ghosts might be disturbed there or in the vicinity? Websites erupted with a profusion of photographs of half-buried gravestones, the names and places of cemeteries, people whose remains had perhaps been moved, destroyed churches, and the like. All of this was par for the course and posed no insuperable problem to an avos' buyer. But the owners of Armada were operating with a different rationality in which the forward planning needed to operate a Chinese-financed firm in a Russian environment must have played a part - one in which they would charge higher prices, and in which creating a good reputation and actual reliability mattered.

As a foundation, they spent two years cultivating the local officials and securing legal documentation. Next, unlike other companies in the city, they got rid of the problem of fallible sub-contractors by setting up their own departments to manufacture the building materials: cement, walling blocks, heat-retention bricks, pipes, and wooden components. This combination of networking with known authorities and relative independence in construction gave them a good basis for completing the buildings. Armada's website also draws attention to its superior concern for quality: its architecture, interior design, and landscaping departments. ${ }^{23}$ None of this, it has to be said, was remarked upon by the potential buyers, but they did notice the company's performance of transparency: it publishes all of the updated prices for the various categories of apartments online, a far from universal practice. Comments began to appear on websites such as, 'I am glad the Chinese are constructing this house - not our [Russian] builders. ${ }^{24}$

Still, the hard-won reputation for reliability did not amount to trust. Misgivings that the company would pull out of their obligation resurfaced, along with other contingencies. Someone commented on the Scarlet Sails forum: 'Is something thinking of tying themselves into this development? BEWARE: business is slack in construction these days; won't the building be frozen? Won't the Chinese take away their capital in connection with the present [Russian] default? And I'm also worried about the presence of old burials on the site. ${ }^{25}$ This was despite the fact that Armada had evoked 'trust' as they saw it. They attached a gigantic glowing heart in red lights to the façade of the most nearly finished of the Scarlet Sails blocks, visible 
across the city at night. This symbolic gesture was to be a binding of, and pledge for, the loyalty of the dol'shchiki. The manager explained: 'Today you can see the first of three houses of the Scarlet Sails complex, which we are planning to bring into use already in 2015. We have placed on it a glowing heart as a symbol of life and love to our clients, who trust us and are just as much participants in the construction as our company, understanding that the final result will depend only on our joint strength, and then no external shocks are to be feared'. ${ }^{26}$ However, popular readings of symbolic acts are difficult to control (Ohnukey-Tierney 2015), and in this case the glowing heart was a foreign gesture to the citizens, ${ }^{27}$ no more than a curiosity, and certainly not taken as a pledge of commitment. Clients warned one another that the zastroishchik's promise of 'electric central heating' would not mean central heating, but only a few electric heaters here and there, which any way would be subject to outages - a doubt seemingly confirmed one day by the heart going out, or being turned off. Either way, it did not bode well.

Smaller companies dispense with establishing reliability and general 'public trust', and instead work with the face-to-face kind. But when the agreed handover time is shifted again and again this personal trust melts away and turns into a feeling of betrayal. Numerous YouTube videos record the acrimonious meetings between infuriated dol'shchiki and the representatives of the contractor, usually junior staff sent to explain the situation. The staff bluster, they offer further solemn promises. And yet sometimes the clients look somewhat cowed, as if they realize that behind all of this is some constellation of power that is beyond the reach of anyone in the room. This leads me to a further paradox. If Armada is regarded as relatively reliable but still not trusted, there are also cases of the reverse, when a company (or rather a known person in the firm) is trusted, even though he cannot be relied upon because he too is held to be subject to 'higher forces' or the system in which everyone is caught up. As one longstanding dol'shchik said,

When not a junior but the managing directors themselves came to explain to us, well, by now they're already known, they're like one of us. We smile to them. And I can't honestly accuse them, though of course

26 http://primgazeta.ru/news/property-in-vladivostok-considerably-more-expensive.

27 Dramatic illumination is a typically Chinese intervention in the urban landscape; it has been deliberately employed in Chinese border cities to demonstrate prosperity, vivacity, and optimism in contrast to the dim shadows of the Russian towns on the other side. 
purely formally I should - you bastards haven't handed over my apartment - but when they show me what they have built earlier and all the papers they have to deal with, simply as a human being I can't blame them. The basic problem is very simple, corruption. [...] Actually, I have nothing but admiration for the CEO. In the most difficult years he built social housing, 87 flats, and he handed them over at cost price, because he himself is a former army officer - basically, that was a social project, for the military, doctors, teachers. And when he came to us and told us that some wretched little official, basically to solve his own problems, concocted this corrupt scheme... well, everyone understands, everyone can see it, even the Procurator, but there's just silence.'. ${ }^{28}$

'Cheated dol'shchiki' have even been known to send symbolic presents slippers and a blanket - to 'their' trusted contractor, even though he was a notorious figure sitting in jail for swindling, saying they did not agree with the public criticism of him, begging him to help them and implying others were really at fault. ${ }^{29}$ In many such cases, it is now the contractors whose clandestine agreements with officials have been ditched, who experience the betrayal of trust, the humiliating feeling of having been dumped. ${ }^{30}$

\section{Betrayal of trust and the real estate landscape of Russia}

Thus, the sense of betrayal is often diverted to another object - to the chinnovniki ('officials'), the vlasti ('powers'), the government (administratsiya; pravitel'stvo), or even the country itself. Protesters carry placards saying: 'Putin V.V.! We demand fulfilment of the Constitution - the problem of dol'shchiki is the problem of the state!' or, simply,'Russia - I am your dol'shchik!'31 The understanding here is that not only does the state have obligations towards its citizens, but the Constitution itself makes this a commitment. In these appeals the age-old stance of the lament (Ries 1997) may surface, appearing as almost ritualized complaint, a self-lacerating litany that also allocates blame: 'We are no more than the dirt under their

28 http://gkontrol.com/publication/3054-postradavshie-dolshhiki-iz-klimovska-o-dejstviyaxgorodskoj-administraczii.

29 http://realty.newsru.com/article/29May2015/dolshiki.

30 Kinut' is another Russian verb that is resistant to translation; it means to be dumped, betrayed, or thrown over.

31 http://www.ikd.ru/node/10971. 
fingernails'; 'So [with no house] I'll show them, I'll just go and sit on the street with nothing but a bottle of water' ${ }^{32}$

Holding the government responsible, many dol'shchiki go further and attempt to wrest financial compensation or the completion of the building from the state. This causes indignation among certain other self-righteous citizens, orchestrated by the media: 'These are people who wanted to buy at a low price knowing there could be all sorts of problems, but they went ahead on the principle "win or lose". They consciously took the risk. Why should the administration compensate them from the budget, which is after all our money, yours and mine, paid from our taxes? [...] Each person should bear the responsibility for his own actions. Can we even say they are 'cheated'? They are just legal illiterates, they should acquaint themselves with the law. ${ }^{33}$ To such accusations, some dol'shchiki have a measured response. They argue that leaving each person to bear their own responsibility benefits only the rich and powerful, and leaves the field open for swindlers. It should not be expected that every citizen be an expert in the law, just as a patient going to the hospital should not be expected to have specialized knowledge of medicine: 'We need to understand a simple thing, that each citizen is not obliged and indeed cannot know all the judicial detail in writing contracts, nor in health care, teaching, aviation or food production. The state structures are created just for this, to protect citizens from mass swindling, mass food poisoning, from collapsing housing and bridges, from falling planes and banks that go bankrupt. But that's not how things happen in Russia'. ${ }^{34}$ In short, the state should regulate matters in such a way that it is not possible for rogues to make fortunes. The state should establish the rules of the game ${ }^{35}$ in such a way that it not necessary to rely on either avos' or personal trust.

32 A relatively mild example was given by the dol'shchik from Klimovsk who had organized a tent camp demonstration in front of the incomplete house:

The fact is, in order to get our zastroishchik out of Klimovsk the authorities are using us like small change, our lives, our fates. Two years have been rubbed out of our lives. Not because we are now living in tents, but because our children are growing up. They could have grown up here, in a beautiful area in a well-appointed apartment. But now they are living in rented rooms. And the place where a child is brought up is probably most important to everyone: where his children and grandchildren will live. Certainly it is to me. Yes, two years really have been erased from life.

http://gkontrol.com/publication/3054-postradavshie-dolshhiki-iz-klimovska-o-dejstviyaxgorodskoj-administraczii.

33 Radio phone-in program. http://radiovesti.ru/episode/show/episode_id/16207.

34 http://www.vened.org/interesting/3055-2009-12-28-04-28-40.html.

35 http://radiovesti.ru/episode/show/episode_id/16207. 


\section{Conclusion}

Although many Russians are wary of purchasing housing through shared construction agreements, this article has been devoted to explaining why large numbers decide to go ahead anyway. It has been shown that real estate transactions in Russia have been set up in such a way - opaque, long drawn-out, and risky - as to suspend an entire variety of actors in a state of uncertainty. Speculation is the initial impetus and trusting an unknown person is the next stage in this situation, both steps highly visual and intuitive - the client likes the look of that place, he trusts the face of that contractor. At the same time, this raises questions about the temporal hinterland of this impulsive act.

An interesting article in a commercial journal explains popular economic practices through the contemporary attitude toward memory. Nikiforov (2015) writes that Russia's main problem is memory - which is too short, too selective, and too mythologized; that is why citizens do not make correct decisions about their own futures and why the government has a short-term view of economic policies. Russians are no longer terrified. They live for the moment. Social enquiries, he continues, have shown that operative memory, even for notable events like the uprising in Ukraine, only lasts two to three years, and then it disappears. As for the future, people tend to optimism and fatalism: prices will always rise, inflation is an immanent attribute of the environment, and people do not look into the reasons for this rise or fall - for them, it is something like the weather. Isolated events in history are ideologized, while whole periods are not taught in schools. Thus young people tend to amalgamate historical time into a single mythological past, which becomes in effect timeless. In economic behaviour, this has the effect that people have begun to operate with very narrow time frames. Even large bank loans and mortgages are taken in a spirit of avos' adventurism:I'll repay for now, but then let's see. Maybe I'll come into an inheritance. Nikitin's views do not contradict anything that has been written in this article. But maybe his analysis of avos' still misses the mark, because it does not take account of the actual popular comprehension of the workings of the Russian market. People do not in fact operate with such a 'narrow timeframe' that they cannot apprehend the presence of the past, anticipate future shocks, or sense the absence of a system. They understand this well. Instead, the multiplicity of bewildering factors, such as opaquely different types of dogovor, malign intentions and deceptive promises, unreliable court decisions, and the arbitrariness of officials, combined with the boons and blows of external events (oil prices, currency swings), mean that contingency 
has to be the name of the game. After all, look around and you see that some people do receive their apartments. In this situation, avos', seizing the chance and taking the risk to trust, are both part of the game and also perhaps the intuitively 'rational' optimum in the circumstances.

\section{Acknowledgements}

I am very grateful to Dominic Martin for his insightful comments on avos', and to Alexei Borkhodoev, Robin Osborne, Natalia Ryzhova and Vera Skvirskaja for their advice and useful references.

\section{References}

Allard, Olivier, 2011. Bureaucratic anxiety: asymmetrical interactions and the role of documents in Orinoco delta, Venezuela. HAU: Journal of Ethnography Theory, 2(2), pp. 234-56.

Allard, Olivier, Matthew Carey, and Rachel Renault, 2016. De l'art de se méfier [On the art of suspicion]. Tracés, 31(3), pp. 7-20.

Antipov, Evgeny and Elena Pokryshevskaya, 2015. Are buyers of apartments superstitious? Evidence from the Russian real estate market. Judgement and Decision Making, 10(6), pp. 590-92.

Berthomé, Francois, Bonhomme, Julien, and Delaplace, Grégory, 2012. Preface : Cultivating uncertainty. HAU Journal, 2(2), pp. 129-137.

Corsin Jiménez, Alberto, 2011. Trust in anthropology. Anthropological Theory, 11(2), pp. 177-96.

Dasgupta, Partha, 1988. Trust as a commodity. In Diego Gambetta (ed.), Trust: Making and Breaking Cooperative Relations. London: Basil Blackwell, pp. 49-73.

Gladkova, Anna, 2004. New and traditional values in contemporary Russian: Natural semantic metalanguage in cross-cultural semantics. Proceedings of the 2004 Conference of the Australian Linguistic Society. http://hdl.handle.net/2123/109.

Graeber, David, 2012. The sword, the sponge and the paradox of performativity. Social Analysis, 56(1), pp. 25-42.

Guenther, Olaf, n.d., Kairos economics at Central Asian Border Lands. Unpublished manuscript.

Hardin, Russell, 1992. The street-level epistemology of trust. Analyse \& Kritik, 14, pp. 152-176.

Hardin, Russell, 2002. Trustand Trustworthiness. New York: Russell Sage Foundation. Hawley, Katherine, 2014. Trust, distrust and commitment. Nous, 48(1), pp. 1-20. 
Humphrey, Caroline (in press). Real estate speculation: the clash of forms at a global frontier of capital. Submitted to Economy and Society, special issue on speculation edited by Laura Bear and Gisa Weszkalnys.

Johnstone, Steven, 2011. A History of Trust in Ancient Greece. Chicago: Chicago University Press.

Maurer, Bill, 2006. The anthropology of money. Annual Review of Anthropology, 35, pp. 15-36.

Miyazaki, Hirokazu, 2006. Economy of dreams: hope in global capitalism and its critiques. Cultural Anthropology, 21(2), pp. 147-172.

Miyazaki, Hirokazu, 2007. Between arbitrage and speculation: an economy of belief and doubt. Economy and Society, 36(3), pp. 396-415.

Nikiforov, Artem, 2015. Avos' - analiz: kak korotkaya pamyat' meshaet grazhdanam bogatet [Analysis of avos': how short memory prevents citizens' enrichment]. Kommersant, 16 November. http://www.kommersant.ru/doc/2850128.

Ohnukey-Tierney, 2015. Flowers that Kill: Communicative Opacity in Political Spaces. Stanford: Stanford University Press.

Oleinik, Anton, 2005. A distrustful economy: an enquiry into foundations of the Russian market. Journal of Economic Issues, 39(1), pp. 53-74.

Radaev, Vadim, 2004. Coping with distrust in emerging Russian markets. In Russell Hardin (ed.), Distrust. New York: Russell Sage Foundation, pp. 233-48.

Ries, Nancy, 1997. Russian Talk: Culture and Conversation during Perestroika. Cornell: Cornell University Press.

Riles, Annelise, 2004. Real time: unwinding technocratic and anthropological knowledge. American Ethnologist, 31(3), pp. 392-405.

Savransky, Martin, 2015. On the problem of attachment: living economies and the ecology of late capitalism. Science as Culture, 24(4), pp. 526-531. doi:10.1080/o9 505431.2015.10796o6.

Shevchenko, Olga, 2002. 'Between the holes': emerging identities and hybrid patterns of consumption in post-socialist Russia. Europe-Asia Studies, 54(6), pp. 841-866.

Shlapentokh, Vladimir, 2006. Trust in public institutions in Russia: the lowest in the world. Communist and Post-Communist Studies, 39(2), pp. 153-74.

Trocheshnikova, Mar'yana, 2016. 'Ni deneg, ni zhil'ya' ['Neither money, nor place to live']. Interview, Radio Svoboda, 24 August.

Wierzbicka, A., 1992. Semantics, Culture and Cognition:Universal Human Concepts in Culture Specific Configurations. Oxford and New York: Oxford University Press. Zaloom, Caitlin, 2003. Ambiguous numbers: trading technologies and interpretation in financial markets. American Ethnologist, 30(2), pp. 258-272.

Zaviska, Jane, 2012. Housing the New Russia. Cornell: Cornell University Press. 


\title{
Searching for Trust
}

\author{
Indigenous People in the Jade Business ${ }^{1}$
}

Tatiana Safonova, István Sántha, and Pavel Sulyandziga

Humphrey, Caroline (ed.), Trust and Mistrust in the Economies of the China-Russia Borderlands. Amsterdam: Amsterdam University Press, 2018

DOI: $10.5117 / 9789089649829 /$ SAFO

\begin{abstract}
The jade mining business is based on a gap in values between Russian producers and Chinese buyers. While in China jade is considered the essence of Chinese culture and a personal obsession, historically it has had no special value in Russia, and few people recognize it as a possible source of profit. But as an illegal trade developed, people began to change their perspective - creating the need for an indigenous company to find trust inside Russia to maintain its business. This chapter first looks at a business strategy that exploits the paradox of the gap in the valuation of jade and works by creating a kind of deliberate absence of trust. We then consider how the search for trust is projected outside of this business strategy, as a hierarchical relationship with possible patrons. We suggest that these manipulations of trust lead to a 'relocation' of the Russia-China border to Moscow, where the decisions about who can cross and exploit the border for profit are ultimately made.
\end{abstract}

Keywords: jade, trust, indigeneity, autonomy, hierarchy

There was much talk about the past of Dima, one of the heads of an Evenki obschina ('family-based enterprise') making money from jade mining in one of the Siberian Republics in Russia. Dima was a wrestler who had then become a wealthy businessman: a trajectory very similar to others

1 This article is one of the results of an ESRC project hosted by the Department of Social Anthropology at the University of Cambridge between 2012 and 2015 . At the early stage it was also supported by a Marie Curie Intra-European Fellowship, and later at MIASU by the British Academy. 
of that time, as described by Vadim Volkov (2002) in his book on violent entrepreneurship. Dima's business was profitable, and he was obviously experienced in protecting it from various attacks and attempts to take it from him and his collaborators. This is why, when the independent research centre where I was then working in St. Petersburg suffered a racketeering attempt - during which the owners of the building tried to blockade the office and force our director to sell it cheaply - I asked Dima what we could do in this situation. At that point we were so desperate that we could not rule out strategies such as finding the attackers' enemies and trying to build a coalition with them, or at least finding something that would help us to fight back. Dima surprised me with his advice to approach the newly established government committee organized to investigate cases of racketeering. I was amazed that he took the work of this committee seriously, since we were ourselves sceptical about the efficiency of any such official state institution. How could he be so naïve? His proposition of trusting state institutions surprised me because the very possibility of an extortion scheme aimed at a research institution seemed to be a sign that the state was not working properly - meaning that I could not trust this state. When I felt needed an alternative strategy, why did Dima trust the state?

In the long term, this trust did not help him: his company was liquidated and a new firm took over the whole sector of jade mining and trading. This new company was protected by officials in Moscow, some of whom turned out be shareholders in the new company. Dima lost his business and had to leave the country under the threat of criminal prosecution. He fought until the end, even applying to the United Nations and defending his company at the highest levels of the Russian courts. His attempts showed that he trusted the state till the end.

In this article we investigate why trust is the only option for business building in Russia, and how this trust is different from what Westerners consider trust to be. An important point is that the jade business itself is based on mistrust between buyers and sellers: the buyers are Chinese people who value jade differently than Russian and Evenki jade miners and traders. In this situation, trust in the state becomes a compensation for the mistrust between trade partners - but this trust is not a rational decision, as when a person decides to trust somebody. Rather, trust becomes a kind of relationship with those who control the spending of profits, which are themselves gained through transactions infused with mistrust. 


\section{Thresholds of Trust}

In a collective volume edited by Diego Gambetta, trust was approached as an analytical category (1988). In his concluding note, the editor suggested that trust is a complex relationship that can be seen as both positive and negative from different perspectives. For example, we would not like our enemies to trust each other, as that trust can be dangerous for us. Too much trust might also prevent competition and consequently affect the participants in a situation in a negative way. Gambetta also remarked that game theory shows that people do not trust each other in the majority of situations, even though such trust can have an overall positive effect on all of the participants. Summarizing articles by other authors of the volume, he further suggested that trust should be seen as a result of cooperation, rather than its predisposition. It is important to see trust not just as a function of some external variables and conditions - people do not trust each other because they are in certain relationships with each other - but rather as a decision to ignore the risks of possible failures. Trust is an instrument that helps to maintain relationships in unpredictable and turbulent conditions. Every time we trust, we open possibilities for risky collaborations. We do not have to trust people that we know have only one possible way to act. In this respect, trust and confidence should be seen as distinct categories, according to Luhmann, who emphasized that trust can appear only in a situation of uncertainty (in Gambetta 1988). Trust characterizes only one spectrum of possible relations, between points of total trust (confidence) and total distrust. This, then, means that trust has thresholds.

In this light, we can ask the following question: how do actors make a decision to trust other actors, and how do these decisions change their relationships? If trust is a product of cooperation, we can assume that trust characterizes not spontaneous relations, but relationships with a certain history of cooperation. At the same time, trust marks these relationships as open to change, because actors take the risk of trusting each other despite the overall uncertainty of the other's future actions (Humphrey, this volume). In other words, trust is an effect of the continuity of contact between actors. Who we trust shows with whom we share a past and a potential future (Park, this volume). Grasseni showed how trust operated as a relational matrix for members of alternative food supply networks in Italy, and how it became a problem when these networks tried to combine into a new overall network, a network of networks (2013). Trust thus involves a problem of autonomy and borders. Actors trust those who do not threaten their autonomy and who are autonomous themselves - and who 
therefore also can be unpredictable. Yet this autonomy is a condition to establish trust. We might suggest that trust needs as a constitutive part a border between those who trust and those that are trusted. Trust bridges separate, autonomous species that suspend their anxiety about possible future failures and proceed with the interaction, despite the risks.

On an ethnographic level, we are interested in trust as an effect of interactions between autonomous actors. We assume that as long as an actor searches for trustworthy partners, he or she exists as an autonomous entity. We propose to look at the history of an indigenous jade mining enterprise as a series of attempts to become a trustworthy partner and to trust others. This perspective will give us a new picture of how business partnerships and coalitions work in contemporary Russia, and how bridging the gap between Russian and Chinese cultural contexts creates the possibility of profits and the autonomous existence of a relatively small, indigenous enterprise.

In the first part of this article, we will show how the jade trade between Russia and China started, and how various factors created the opportunity for an Evenki company to virtually monopolize the sector (at least in its legal form). Great profits were possible here because the value of jade is vastly different in Russia and China. This means that a successful business should conserve the paradoxical situation in which relationships of trust between traders and buyers do not diminish differences in the valuing of jade. In other words, the fact that Chinese buyers value jade highly should not affect the Russians, for whom jade should remain not very precious. However, successful and continuous trade threatens this situation, as the sellers and buyers obtain more and more knowledge about the product and their perspectives begin to merge with each other. The gap in the value of jade in Russia and China was a result of a long and complex history, and this complexity permitted Evenki people to establish trade with Chinese buyers without sharing their own perspectives and feelings about jade.

In the second part of this article, we describe how the enterprise arose and was then closed. Giving a first-person account of this situation - Pavel, one of the authors of this chapter, was personally involved as a public external representative of the company - we show how the strategies of building trust with Chinese buyers and Russian authorities differed in the way the Evenki interacted with these contrasted parties. In Russia, competition with those who wanted to grab the company's economic niche was built around the aim of finding a trustworthy partner at a high level of the vertical of power (vertikal' vlasti, as the hierarchical power structure is designated in Russian media). Once the competitors reached the highest of possible levels, namely the president, the competition was over and the company was both 
liquidated and actually taken over by the winning group. The Evenki lost control over the industry. In the conclusion, we will return to our research question and reflect on the role of the centre/periphery axis for building trust in the Russian business world. We will show that searching for trust relocates the real border between Russia and China from Siberia and the Far East to Moscow and Beijing; and hence the national and economic borders are re-situated from peripheral to central locales.

\section{Untrustworthy Jade}

Gambetta's edited volume excluded nonhuman agents from the sphere of trust and studied only human-human trust relations. But in our common life we frequently see some 'objects' as tricky and not trustable. Jade is such an object: a stone with a strange and unpredictable price that can be trusted to maintain its shape and structure through centuries, but cannot be trusted to mean the same things to different people. We may suppose that distrust or trust can be fetishized, and that the quality of the relationship between certain humans is projected on the object that symbolizes these relationships. Thus untrustworthy jade is a symbol of the absence of trust between its Russian sellers and Chinese buyers. In this section we examine aspects of this distrust and the strategies people employ to build trust despite the untrustworthiness of the material they work with, despite the structural reproduction of distrust between the partners.

The paradox of the jade trade is the following: jade is valuable in China, but only if the stone is connected with Chinese history. Jade from Siberia, even if it is high quality and has a rare white colour, cannot become a highly priced commodity in China where jade carvings are valued for their essence: their relation to China. To be valuable, jade objects should either be from archaeological excavations or antiquity collections, or should be made from the same material as famous historical objects. This means they should be from China. But the jade market in China is growing and demanding more and more jade, so internal sources cannot cope with the demand. Historically, jade is not valued in Russia (where it is known as nephrite), and this means that there is no special state control over its trade. Officially, Siberian jade costs so little that there are no plans to research and develop interest in jade in Russia; as a result it remains an unimportant resource: just a stone with some specific chemical and geological qualities. Because of this invisibility, jade traders can smuggle jade from Russia to China comparatively easily, where it then disappears and reappears on the market 
as an 'authentic' Chinese stone from internal mines. Enormous profits are based on the maintenance of this drastic difference in the valuation of jade, and any company that wants to be successful in the jade trade between Russia and China should be careful to sustain this paradox: keep jade a a simple stone on the Russian side, and turn the same object into Chinese jade on the Chinese side of the border. In this respect, the jade trading company acts like the investment bankers in Miyazaki's research, which showed how people search for discrepancies in assets' prices and make profits through the annihilation of these discrepancies (2013). This strategy is called arbitrage; the jade trade is comparable to arbitrage, because the stronger and more stable it becomes the more obvious the discrepancy in the valuation of jade, and as a result sooner or later the regimes of value must change and merge with each other. The jade trading company, then, must simultaneously create a bridge between two worlds and keep those worlds apart.

A question that appears in this respect is: how did the gap appear in the first place? If the mineral can be found on both sides of the border, how did it find such a different place in the cultures of neighbouring societies? Another question is: how does the need to maintain a gap of misunderstanding and discrepancy in values affect the position and structure of a company in this business? If a firm needs to protect a border between societies to secure a profitable environment, how can it be transparent itself? It is important to understand that the gap in the valuation of jade by Chinese buyers and Russian sellers was a product of historical collisions. If we look at the history of jade in detail we will see how many conflicts and unresolved clashes of interest are packed into the phenomenon, which we might call 'the ignorance of jade in Russia'. The same is true for the Chinese side, which values itself through the jade and simultaneously ignores the fact that there is no such thing as purely Chinese jade: the stone was always an imported product.

\section{Jade in China and Russia}

The recent Chinese enthusiasm for jade is related to several interconnected factors. Obviously, there is a long and fertile history of this mineral in China; jade objects are frequently found in archaeological sites associated with the origins of Chinese culture. But this rich story does not explain why jade became such an obsession when China started to economically develop in the 1980s. Jade actually became a form of investment for the Chinese 
rich: jade converts financial status into power, the precious form of power associated with the imperial court of Great China. In earlier times, jade was reserved almost exclusively for the use of the Emperor and members of his family. The Imperial Palace in Beijing is packed with objects made from jade, from Imperial stamps to cups and dishes. During some historical periods, this material was even forbidden to ordinary people. The history of jade combines and unites various Chinese dynasties as well as geographical areas. It is extracted mainly in the north of the country, but is most revered by people in southern regions. Some jade objects carry traits of several historical periods simultaneously: crafted at one point, then excavated from tombs several centuries later, repaired and carved again several centuries later, then sold at auction now. Due to its durability, jade remains relatively well preserved and therefore functions as a point of connection between the long past, the present, and the distant future. ${ }^{2}$ Jade integrates the complex history of China, and simultaneously makes it a distinct and special history, in which gold does not play as important a role as it played in the West. Jade symbolizes something more than any Western concept of power, prosperity, or harmony can grasp. Jade, many Chinese believe, is the essence of China.

With the rise of the Chinese economy several factors have made jade (and fake jade) a perfect object of investment. One factor is that the overall rise of living standards and the flow of capital created conditions to push the housing industry and open new building sites. There is a law obliging builders who find an archaeological object at their site to inform the authorities - who would subsequently close the project and initiate proper archaeological research - and therefore many companies preferred to keep such discoveries a secret so that they can carry on building. As a result, a flow of newly found jade objects entered the black market. Many of these objects were unique and not described by scholars; they were mixed up with fake jade objects, and the jade antiquarian market inside China became a risky business - not only because most of it was illegal, but also because the process of authentication became highly problematic. Since rich Chinese could obtain only a limited amount of immobile property (real estate), the demand for jade led to a rise in prices, infusing the market with even higher risk.

In this situation, legal authentication was not possible inside China, so Chinese buyers turned to specialists and institutions abroad, mainly global

2 Jade became so significant for Chinese scholars that archaeologists and historians proposed inserting a Jade Age into the global historic three-age system, following the Stone and before the Bronze and the Iron Ages. 
Figure 14 Chinese buyers scrupulously explore an old Chinese object put on sale at Sotheby's auction house in London, UK

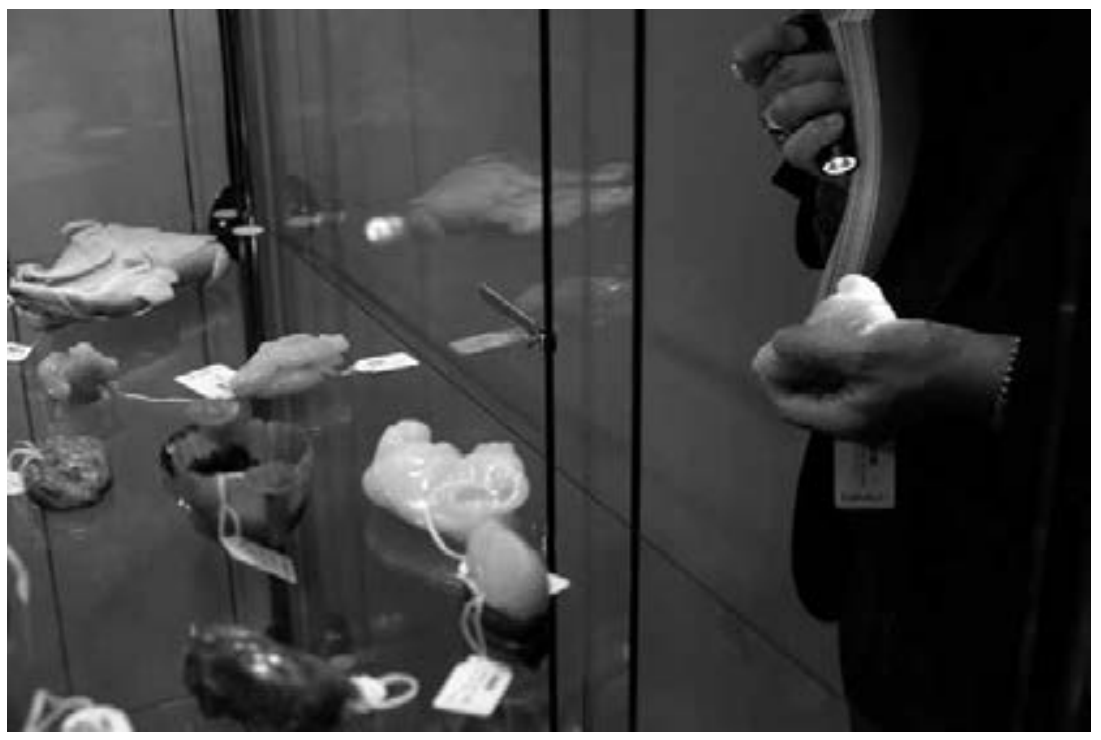

auction houses such as Christie's, Sotheby's, and Bonhams (see Figure 14). There are various scientific procedures that can help estimate whether a jade object is authentic, but there are several obstacles to this, so no analysis can provide absolute certainty. ${ }^{3}$ Recently produced fakes are the easiest to detect, because the activity embodies the contextual features of its time: a different attitude to the speed of production and stone quality. ${ }^{4}$ Experts and object retailers are usually more educated and experienced than forgers and can detect what shapes and patterns refer to which periods. Forgers often replicate objects that they have never seen in real life, guided only by illustrations. Sometimes they wrongly interpret these illustrations and

3 The word 'jade' in ancient China referred not only to what we now call jade, but also to various other stones, and even to glass. So some objects may look like jade, but not be jade, while still being authentic ancient pieces. Those who make fakes often use the same technologies as ancient carvers, and as a result examination under a microscope will reveal the same marks and structure, as if the object was produced long ago. Third, fakes were also created many centuries ago, so an object may imitate an artefact from several thousand years before, but still be a piece with antiquarian merit, several centuries old (Wilson 2004).

4 In traditional terms, newly produced jade objects are never fully finished because is money for their producers time, which was totally different for their predecessors, who could spend half of their life on crafting one object. For the experienced jade expert, the impression that the object is unfinished becomes an important source of doubt (Keverne 2010). 
carve shapes that were just illusions produced by specific angles of projections, or create objects at a wrong scale. The main problem for the forger is the need to speed up time, so that the jade object experiences harsh environmental pressure over several days to create the impression of lying in soil for several thousands of years. Sometimes they burn the stones, use acid, or even bury them with dead dogs. Very rarely do these tricks work and make the objects look ancient. Still, for their buyers, all of this could be enough to prevent any further investigation, and faked objects appear in the catalogues of their collections, smuggling incorrect patterns into the pool of officially accepted, authentic ornaments.

As a result of this complexity, jade prices often depend on the affective response that objects provoke in their buyers. Prices for the raw material that is used mainly to create faked antiquarian pieces (the market for modern jade sculpture is relatively young and very limited) depend in principle on the prices of authentically proven antique objects. ${ }^{5}$ Yet in practice auction battles became an important way to define the prices for jade, and during such short and intense exchanges the affect of the object plays the most important role as date estimations and risk calculations are not possible on the spot. Jade becomes a trophy for its buyers, including in cases of capital investment. For those who mine jade outside of China the mechanisms of jade valuation remain mostly obscure, and the only way to achieve a high price is to invite competing buyers and organize an auction. The context is so complex that non-Chinese experts without regular access to internal and external jade markets cannot predict the price for raw jade minerals.

We can suppose that there were several opportunities for jade to become a precious stone in Russia. It is very important to understand why this did not happen, because then the gap between Russian and Chinese knowledge about jade can be understood from a new perspective. Jade objects are not rare in Neolithic archaeological sites excavated on Russian territory, but these objects were never connected with each other to create a basis for the interpretation of their cultural origin. On the contrary, jade objects stayed at the periphery of archaeological research: they were dispersed among local museums and did not constitute a solid collection in any central research or museum institution. Analyses of these jade samples were rarely conducted.

5 These prices can be exceptionally high: at one recent auction in London, a seal stamp that looked very much like an imperial one, but still with undefined origins, was sold for £40o,ooo. The stamp itself was thought to have been produced in the 18th century, but in its form it mimicked a Neolithic object of undefined function; also, it was made of white jade and in very good condition. Although specialists could not exclude a small chance that it was a fake, the object appealed to competing bidders and the fight for it was dramatic. 
What united all of these objects was the common opinion that jade was used in Neolithic times only as a material to make durable instruments and was not used for decoration. Although jade mines are known in several parts of Siberia, ${ }^{6}$ they were never studied as the nodes in an archaic jade trade that possibly existed in those distant times. There were confusing contrary suggestions: that all jade was from the current Chinese territories, or that the recently discovered jade deposits were simply unknown to the local tribes. These interpretations say a lot about the political environment of the time they were produced, a period when maintaining a cultural and geographical boundary between the Russian Empire (later the Soviet Union) and China was an important task affecting researchers as well as statesmen. The stereotype that jade as a sacred stone only characterized cultures influenced by China was so strong that it was easier to ignore the presence of jade objects altogether than to open the sensitive question of the history of the southern and eastern territories of Siberia and the Far East. In contrast, remarkably different theories have emerged in Western institutions, where the hypothesis that many jade objects found in Chinese archaeological sites were actually produced with Siberian jade and carry motifs atypical of Chinese culture (such as deer) is finding new support.

The neglect of jade objects from archaeological sites does not mean that there was no attempt to create a Russian tradition of jade carving. Jade became one of the precious materials associated with the name of Peter Carl Fabergé, the imperial jeweller under whose supervision the famous enamel eggs were created. Using the Russian tradition of giving an egg as a present to your loved ones for Easter, between 1885 and 1917 Fabergé's company produced many jewelled eggs for the Tsar's family, many either made from or decorated with jade or minerals close to nephrite (see Figure 15). Fabergé initiated a fashion for jade objects, from jewellery to cigarette cases. Most of this jade was green and from deposits in the Sayan Mountains, but there were also attempts to import white jade from China, although this was found to be too expensive. With the fall of the monarchy this fashion abruptly ended, and many of the items were sold by the Bolsheviks, who needed foreign currency. The interest in Fabergé's art was revived after the fall of the Soviet Union and the nouveaux riches from Russia started to hunt for eggs and other Fabergé jewellery at antiquarian auctions. They were seen as symbols of Russian pre-Soviet prestige, power, and spirit: something that the new authorities would like to restore or at least associate with. But this

6 Nephrite was not exploited until the 18th century, except for some small indigenous mines in East Siberia, West Baikalia, and in the East Sayan Mountains, where local people traded it. 
Figure 15 Carl Fabergé's Easter egg, made predominantly of jade from a private collection of Viktor Vekselberg, the fourth richest person in Russia. The object is on display at special private museum in Saint-Petersburg, Russia

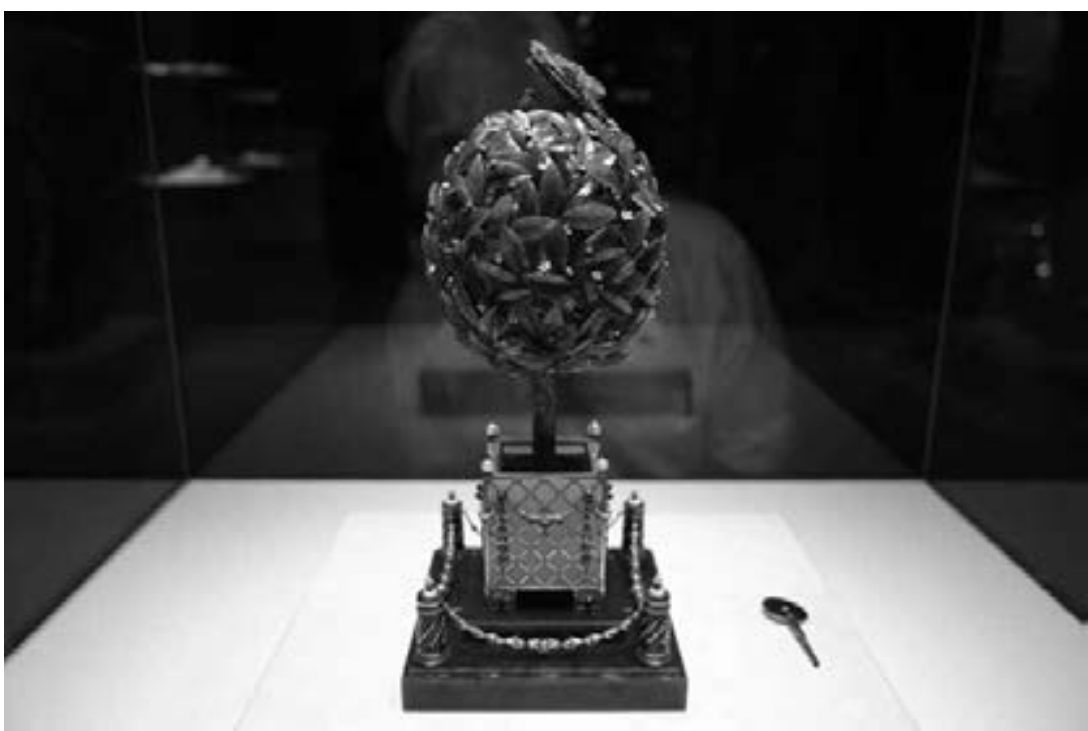

was part of an elitist lifestyle and jade was never reconfigured as a Russian stone in a democratic sense: it did not become popular or recognizable, and no artisan craft arose to work the stone into objects of value. This situation was in some ways similar to the heyday of jade in Chinese history, when only the members of royal family and those close to it were permitted to own jade. Even though jade objects like imperial eggs are of Russian origin, their price now is determined at auctions abroad, and foreign experts play important roles in the process. In this respect Russian buyers are similar to Chinese ones: they buy these objects because of the emotional ties they feel towards them.

\section{The jade trade and the story of Sunshine's rise and fall}

When China's economy started to expand and the borders between Russia and China slightly opened, jade was among the first things that interested Chinese buyers. From the early 1990s people in Siberia started to collect jade pebbles in rivers, as they could be sold for enormous prices according to the standards of that time. In fact, pebbles are sometimes considered 
more precious than raw mined stones, because they are seen as naturally sculptured. Pebbles that carry features in which figures of people or animals can be discerned have incomparable value. At the start of the 199 os an indigenous Evenki company that was originally trying to pan for gold recognized that jade would be a more profitable direction. The discovery of a huge rare white jade deposit in the territory of another Evenki indigenous community led to a most profitable merger. The Evenki still did not know why Chinese people were eager to buy jade, but they definitely understood the environment of which this stone was part. Chinese buyers were technically, legally, and practically cut off from the jade deposits, which were situated deep in the taiga forest. This situation created a niche for an indigenous mining company, and a paradox in which the only firm thing that people were dealing with was the 'untrustworthy jade', while all other relations and associations were continuously disintegrating.

As we have seen, the trans-border jade trade is profitable only so long as it stays illicit and invisible, to some extent even illegal (c.f. Holzlehner, this volume). The Evenkis had an opportunity to keep this business more or less out of the public eye because raw jade had no recognizable value in post-Soviet Russia. They transported lorries packed with jade across the Russian-Chinese border with all the necessary papers, in which jade was documented as a stone for building and decorative purposes. The company also paid all of the necessary taxes from the profits of its mining activities, and was one of the leading taxpayers in its region. So for the twenty years of the company's existence, it was capable of simultaneously developing and extending the trade and keeping it out of the public eye. In a way, it was supporting a regime involving the deliberate absence of trust between jade miners and Chinese traders. Any form of collaboration between individuals from these two sides was seen as dangerous for the integrity of the company and the success of its business strategy. Chinese buyers were never allowed to visit the mining places, and neither were Sunshine's workers sent to China to visit Chinese jade mines or jade trading centres. To our surprise, Sunshine's owners and workers only had a vague idea of why white jade was so precious for Chinese people, and nobody ever tried to trace the further paths of their stones in China.

The company's name can be translated as Sunshine, and like the sun it shone and then disappeared. It started as a small family-based business, a shop for hunters in a distant village without even a permanent road to the central settlement. This had been set up by the head of a local reindeerherding section of the collective farm. His son and daughter helped from the beginning and were involved in the organization of the small shop 
that traded ammunition with local hunters and collected furs from them, mainly sable and squirrel. Some of the furs were sold officially to state collectors, but a substantial portion, along with various strange products such as the internal organs of wild animals used in traditional medicines, were sold to Chinese private buyers. These were the first contacts with the Chinese market, and were often mediated either by local Chinese people (i.e., settled for decades in Siberia) or Evenki people from China. In 1990 the administration of the district accepted and registered the company as an indigenous company in the administrative category of 'Small People of the North'. With this preferential status the company was exempt from paying taxes as long as its activities were connected with the traditional indigenous way of life, mainly hunting, reindeer herding, and fishing. The small shop was able to open because of an exception permitted by the law, by which a small-scale ammunition shop was seen as a legitimate part of the traditional indigenous economy.

In the beginning the shop was not at all a profitable endeavour: the co-villagers remember that in those days the family struggled to survive. The main source of income was collecting fur from local hunters and reselling it to Chinese buyers. In 1993, when the district was awarded Evenki indigenous status, the company got access to various programs of support for Evenki people, which opened new possibilities and horizons for development. In 1994 the company participated in a tendering process and got a license for gold extraction in the region. Now they moved from their village of origin and opened an office with a warehouse in the central settlement of the district. During the first years they were actually washing, rather than mining, gold - working at the sites of old mines and recycling the sand left after the extraction. New technologies made it possible to make a profit and develop the infrastructure of the company. To maintain their status as an indigenous company, they supported hunting and also sponsored various local Evenki events, promoting culture and traditional knowledge. The company was involved in gold mining between 1994 and 2007 but it was never a main source of profit, mainly because the gold market is monopolized by the state in Russia and prices are unfair and unsustainable for small-scale gold miners. But gold mining was a recognized and respected activity in this region, which has been known for its gold deposits since the 18th century. Although gold mining was not seen as a typically indigenous activity, it was still a traditional activity for the region, and when an indigenous company entered this field it was not perceived as something unthinkable and impossible. The company was paying taxes from its profits from gold mining on a regular basis, although in all other respects it was exempt from taxation. 
At the start of the 1990s, collecting jade pebbles became popular among local adventurers and hunters. Pebbles were highly prized by Chinese buyers. Since the beginning of the 1980 s it had been known that there were several deposits of jade in the region, both green and white. Geologists discovered samples of jade during general geological investigations, and then the administration of the republic (of which the district was a part) ordered expeditions to find the good deposits. These were the times of decentralization, and it is remarkable that a geological company from a neighbouring district was hired rather than any central body from Moscow or St. Petersburg, as had previously happened in the Soviet 1970s and 1980s. These local geologists were also the first to get mining licenses, but for various reasons they could not manage the extraction, and in 1997 Sunshine got a twenty-year license for jade mining in the region. As we can see, at this time business initiatives and investments were locally focused and shaped mainly by the demand from international buyers, in this case the Chinese. The company grew fast because of the stable flow of international currency. At the beginning jade was collected, rather than extracted. The environment was harsh, but people used their hunting skills and even preferred to work in winter, when the territory was more accessible and the rivers from which stones were collected were partially frozen. Only in 1996 did collecting jade pebbles become a profitable activity; before it had been seen only as complementary to gold mining.

By 2000 the company started to extract jade from the main deposit, using dynamite and transporting stones in winter. The deposit was situated deep in the taiga, meaning that it was only possible for transport vehicles to reach it in winter along frozen rivers. At this time Sunshine united with another Evenki indigenous company that specialized in reindeer herding. Not only were the reindeer herding territories situated between the jade deposits, but the main deposit itself was located not far from the original territories of this Evenki family. They had a unique knowledge of the habitat, the ways to travel there and where to cross the rivers (see Figure 16). After the merger of the two family-based obschinas, Sunshine strengthened its so-called 'indigenousness' by supporting reindeer herding and hunting on a new, grand scale; at the same time it also gained important knowledge and the opportunity to build infrastructure for the development of jade mining. At the beginning of 2000 a new route to the deposit was established. Most importantly, this route made it possible to commute between the deposit and the district centre in summer, and thus to operate a full mining season. It was also possible to travel by military all-terrain vehicles, which was more expensive but also incomparably more effective and safe. The route went 
Figure 16 One of the Sunshine's operations. Guards reload raw jade to transport it across a river. Jade is on its way from mine to warehouse

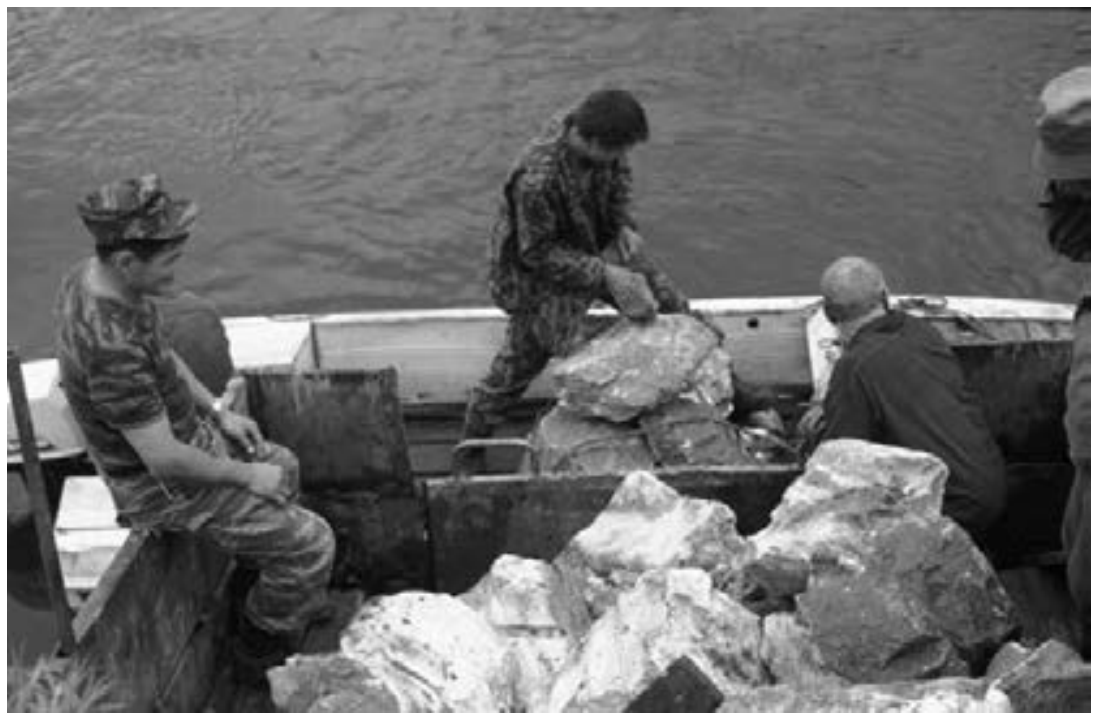

through the reindeer farm, which was simultaneously used as a storage place, watch post, and canteen. All of these changes were also very much in favour of the reindeer herders, who had often suffered from the lack of supplies before.

After these changes the company started to grow and transform into a complex business structure. It obtained several other companies and firms that were previously owned by the state and had become bankrupt. By 2004 Sunshine owned dairy and meat factories. It also owned many buildings and built several stations in the area to make the transportation of jade more efficient. They also bought equipment from China and built a new brick factory, using the bricks to build their own infrastructure. Sunshine became a small but self-sufficient corporation, with its own lawyers (some of Evenki origin educated with the support of the company), its own financial and administrative department (situated in a separate building in the centre of the district capital), several warehouses for the storage of jade and logistic purposes, a park of military all-terrain vehicles, lorries, etc. Sunshine had its own security team, but also from time to time hired private security brigades as well. To expand and protect this huge network of facilities and people, the head of the company decided to become a deputy in the regional parliament, and in 2002 his sister became the head of the company. Her 
contribution to the company administration was not just nominal: she was active and involved in main company issues right from the beginning. The larger the company grew, the more people became attracted to it, both as rivals and as eager partners; sometimes these roles were accomplished simultaneously. In 2004 the former head of the company was elected the head of administration of the district. He enrolled in the advanced education course for state managers (a programme supported by the president) in Moscow. The company was growing fast, its profits becoming more and more visible, and its leaders more and more influential themselves.

In 2005 there was an experiment in which Sunshine hired Chinese stone-carvers, as it tried to change its role in the jade market. But as we have seen, there were structural reasons why contemporary carved jade objects were not valuable in China. As a result, the experiment failed, and the Chinese master carvers ran away with the best samples of white jade. They even dug a small tunnel under the fence of the warehouses to steal the precious stones. This event was recited numerous times and always used as an illustration that Chinese people could not be trusted and should be excluded from all phases of jade production, which contributed to the atmosphere of deliberate and useful mistrust. Around that time, other competitors challenged Sunshine for the first time and made attempts to expropriate the business. But this stayed invisible to the general public, to whom the company seemed to be growing stronger and grander every day.

In 2008, when the rest of the world was struggling with the global economic crisis, Sunshine was shining as though nothing was wrong. The Beijing Olympic Games created a jade fever in the market, Chinese buyers were preparing to sell jade to visiting tourists, and jade became a kind of emblem of the Games. Medals were carved out of white, green, and black jade. Sunshine opened a second mine, and complemented its main white jade supply with a green one. At the same time the Sunshine corporation also started to get rid of ineffective assets. First the dairy and meat factories were sold; then the brick factory was closed. It became obvious that Sunshine would not manage to expand beyond its jade specialization. However hard the heads of the company tried, all profits were exclusively connected to the jade. Even gold mining was abolished. So then Sunshine set out to maximize its profits from jade, and did not try to expand its activities through other investments. The global crisis was an important factor in the company's narrowed focus, but not just because of the risks: Sunshine needed more and more cash and could not carry investments any longer because in the Russian business environment it had to pay larger and larger bribes to continue working smoothly. The appetites of the local and central 
authorities grew, and because the jade market in China seemed so obscure and looked as if it had no limits at all, the demand for bribes was unbridled and became a huge burden for the company. Thus the opacity of the jade trade and above all its logic in Russia forced Sunshine to search for an authoritative and trustworthy patron to shield them from these demands.

In 2009 Dima decided not to participate in the elections for the position of the head of the Evenki district again. As a result, Sunshine lost control over regional and district level power. We may speculate that the price of his participation in such elections was now unbearable, or that some sort of decision had already been made concerning the future of the company. In 2013 the company was closed, and the heads left the country. Many public scandals and battles accompanied this closure. Sunshine was accused of illegal mining outside of its licensed territories. The status of the company as indigenous was also questioned. Jade seized from Sunshine's warehouses went missing, and now nobody knows where it is. A newly organized company obtained a license to work on Sunshine's territories, but its levels of extraction never reached those of Sunshine. Meanwhile Sunshine struggled in the courts and reached the highest level, the Supreme Court, where it failed in its attempt to protest the improper liquidation that looked more like a raiding attempt. Sunshine was officially liquidated, although the practical process of its liquidation became very complicated and lasted until 2015 .

\section{What searching for trust looks like from the inside}

Let us however go back to the start of the search for trust. A very important perspective on trust can be reconstructed from an insider's position. It is clear that the decision of whether to trust, whom to trust, and why, is often based on insider knowledge and experience, and as such is opaque and unclear to observers. To overcome this problem and create a shift of perspectives we have decided to incorporate the voice of a participant. In the following, Pavel describes how he tried to help Sunshine find influential partners to trust, and how its competitors tried to do the same.

The story of my acquaintance with the leaders of Sunshine started in 2005 or 2006. They contacted me in search of help after, according to them, the Vice-Minister of Natural Resources of $\mathrm{N}$ called them in to say that they had to give their business away. Sunshine proposed to work in collaboration, but this was rejected on the basis that the decision had 
been sent 'from the top' - and if they did not accept it, they would face consequences. Naturally, Sunshine did not comply with the imposition to hand over their business. After that, they were bombarded with numerous audits and inspections from local and federal authorities, the police, the Ministry of Internal Affairs, and the tax office. Meanwhile Sunshine was among the top ten companies with the largest tax contribution in $\mathrm{N}$. They paid go million roubles every year.

They realized how serious the situation was after a second meeting with N's chief Prosecutor, during which he once again asked them to give away the business voluntarily. Because everybody in $\mathrm{N}$ knew that the Prosecutor was corrupt, engaged in undercover business, and that there was a standard amount of bribe money that he asked for, the heads of the company were emboldened to offer him a bribe. But the Prosecutor said that he did not need money: he was asking for the whole enterprise. After that, the heads started to look for somebody who could help them in this situation: in other words, they searched for trust. They contacted me. At that time I had good relations with the President's administration; I was a member of the Civic Chamber. I turned to the President's administration and met one of Surkov's assistants, ${ }^{7}$ explaining the whole situation. And then Surkov's people called the Deputy Presidential Representative of the region. ${ }^{8}$ Afterwards they suggested that I personally meet the President's Plenipotentiary Representative in another city to describe the situation. I went there, and he already knew what I would be talking about. There was also another person present at the meeting, a member of the Federal Security Bureau (FSB). This person told me, 'Pavel Vasilievich, you understand that if it is all connected to the chief Prosecutor, whose main responsibility is to guarantee compliance with the law and through whom all the cases go, there is no sense to just come to him and complain that somebody's rights are not respected.' And I remember how we sat there for three hours trying to find a solution; you could say we prepared a whole 'battle plan'. It was decided to organize a workshop connected to Sunshine to study the positive experience of a family-based communal enterprise. By that time there was already a committee devoted to indigenous issues attached to the Presidential Representative's administration, and it was suggested that this body

7 Vladislav Surkov was First Deputy Chief of the Russian Presidential Administration from 1999 to 2011.

8 In 2000 eight federal regions of Russia were created and Plenipotentiary Representatives of the President of the Federation were appointed to each of them. 
should be in charge of the workshop and cover all the organizational issues. It was decided that the Representative's office would conduct its own inspection of the enterprise, and if this were positive it would prepare resolutions and recommendations for all branches of the local authorities to support Sunshine because of its exemplary role for other such indigenous enterprises.

And this seminar really was organized with the heads of Sunshine and the representatives of indigenous business organizations from other regions. It actually raised a furore. And I personally believe that nobody could reach such a level of success in a short time as Sunshine. I think that this enterprise should have been cared for and supported, because they reached such heights of success legally. This enterprise was investing huge amounts of money into the development of its people. Reindeer herding, hunting, fishing: we understand that these activities are unprofitable, especially for small and indigenous people in market conditions. Yet reindeer herding and hunting were really developing there, because they were supported from the profits of the other activities of Sunshine. It was not only jade extraction that brought income, they also had a bread factory, dairy factory, and were engaged in other socially beneficial activities. For example, it seems to me in 2010 or 2011, when the enterprise was still working, there was a small plane crash. The passengers were saved by reindeer herders from Sunshine. The airplane fell deep in the taiga in an almost unreachable place. Herders found the plane, were first to reach the place, and evacuated people from there by reindeer. They brought the passengers to their camp, everybody was saved and nobody was frozen. So we conducted the event with the participation of the Presidential Representative in the region, the President of $\mathrm{N}$, and all the other top leaders. As a result, the Sunshine bosses told me later, they were invited over by the Prosecutor, who said that since they had managed to find a connection to Moscow they could keep going for a while. And then they were left in peace.

This peace continued until 2012, when a serious attack was initiated with the use of 'heavy artillery'. Armed officers arrived, a Special Purpose Mobility Unit (SPMU) - and it was a Moscow SPMU, with investigators from Moscow as well. They commandeered the storehouses, closed the mine, occupied the Sunshine office, and even closed one road. This was done at the demand of Mr. S. (who is now in jail, by the way). On his orders a criminal case was opened, accusing Sunshine of stealing state property. The damages to the state were assessed at 600 million roubles. These accusations were based on one argument, that Sunshine started 
extraction beyond its licensed territories. But these accusations were not new; the company had already been inspected on this issue several times and knew every centimetre of their borders. Naturally the whole affair was concocted out of nothing.

And the most outrageous thing - they took two members of Sunshine's personnel and took them away to an unknown destination. We started to make official inquiries, I as well in the name of the Civic Chamber, because formally they were not arrested. After a month one of them was freed. He then called the heads of Sunshine asking for an apology, and confirmed that he had signed some documents when he was asked. The second person was kept for three months. But we knew that he was alive, because he managed to call his wife and tell her that he was alive but under pressure, and they tried to force him to sign papers against the heads of Sunshine. In the end they released him, but he promised not to submit any complaint. And he also said that he was kept in a house that belonged to a brother of the vice-Prime Minister of N.

Who ordered all of this? I think, this is my suspicion, that the Prosecutor of $\mathrm{N}$ was behind these events: he was also the former head of N's FSB. Why? Because simultaneously, while all this was happening, he became head of a new company, the Russian Jade Company, that was positioned by the authorities as a state company to control all jade mining and exclude private firms. It was then already clear that this company was registered in Cyprus and was an offshore. And the owners of this company, as I assume, are close to Mr. Ch., the head of a state corporation called Russian Developments, which was one of the founders of the Russian Jade Company. The corporation owned 10 percent of the new Jade Company, and all the rest belonged to private investors.

Why do I think that Mr. Ch. is involved? I understand that Mr. Ch. might not know anything about it, because his corporation is turning over hundreds of billions of dollars and a tiny family-based enterprise with a small turnover is of no interest to him. But lesser people from his circles could become interested. Why am I sure of this? When the enterprise contacted me once again, I managed to include the Civic Chamber, we held several publicity meetings, and a special letter from the United Nations was sent to the government enquiring about the situation around this indigenous enterprise. The media started to write about it: Izvestiya, Kommersant, the main newspapers, a lot was said on the Internet.

It is also important that all of the jade that had been stored by Sunshine, and there was a lot of it, all of this jade was transported to the warehouses of the Russian Jade Company. Ultimately all of this jade was 
stolen; nothing was left. This former FSB general became the head of the Russian Jade Company.

When a fuss around this situation was made in the media, three investigations were ordered concerning whether Sunshine was extracting jade outside of its licensed borders. Two were ordered by Sunshine itself, and one by the police. All three, including the police, showed that the enterprise did not overstep its licensed territories by even one centimetre. When the officials realized that they could not officially proceed, and that the public clamour was impossible to ignore, they contacted Mr. Ch., who is known to be a friend of the President. I am sure. I saw a letter from him to the President, and this letter was printed on the letterhead notepaper of Russian Developments. It is not clear why Mr. Ch. should be bothered by a situation around a small company. But he was writing a letter to the President; he wrote: 'Dear Mr. President, please examine the case of the Sunshine enterprise, which is involved in smuggling, illegal business activities, and so forth'. This means he was asking the President of the country to study the case of such a small company! It was understood that without including such strong leverage, they could not resolve the situation. I saw the response to this letter myself, with the President's personal signature, with a resolution to send this letter to Chaika, Bastrykin, and Kolokoltsev ${ }^{9}$ for them to investigate and report back. And so the attackers on Sunshine realized that they could do whatever they want, and that they actually did not need a criminal case against Sunshine. And they followed the easiest way: the state Prosecutor of N, who was trying to obtain the business, applied to the court to liquidate the enterprise, because its activities were not in line with Russian law. There were two main accusations: 1) that out of four founders of the enterprise, two were not registered at the place where the enterprise was registered; 2) the enterprise's status was incorrect, as it was involved not only in traditional activities but also non-traditional as well.

There are broader implications of this situation. The Chief of an Native American tribe, Willy Littlechild, who was in $\mathrm{N}$ in connection with the public campaign around Sunshine, said that this was a case of 'economic discrimination' - because indigenous people of the Russian Federation seemed to be disbarred from activities that are not traditional.

9 Yury Chaika was the Prosecutor general of Russia, Alexander Bastrykin is the Head of The Investigative Committee of Russia, and Vladimir Kolokoltsev is the Russian Minister of Internal Affairs 
Nevertheless, the court decided that this argument was not important and ordered the enterprise to close.

I also want to mention that the list of traditional activities was initially created by the Association of Indigenous People of the North and then was accepted and authorized by the Russian government. I was the initiator of this, and our Association reached the federal level to create the list. We initiated it with the simple intention of protecting such indigenous companies, so that they could apply for state funding to support these traditional occupations. And bureaucrats later turned it all upside down, and started to interpret this list as an instrument to limit the activities of these companies. And so Sunshine was liquidated on this basis and all of the jade was stolen. I know that later this FSB general was dismissed because he had not managed to do everything without a public fuss and another person became head of the Russian Jade Company. And then the FSB general tried to use his connections to punish me: I was accused of being a spy and a traitor.

Unfortunately, this was the end of Sunshine. All appeal cases were lost. Now I know that because there was so much public fuss, they created a new offshore company and all jade business was redirected from the Russian Jade Company to this new one. The criminal case against Sunshine is still open. It is clear that nobody can be prosecuted, because all expert investigations have shown that there was no overstep. But lawyers say that keeping it open was done on purpose, to keep people on the hook. As I know, the heads had to leave the country for China. And I know that Chinese intelligence services prevented an attempt to kill them - and the criminals who attempted the murder confirmed that the order was from Russia.

I want to underline that Sunshine reached unprecedented success that nobody else could reach in the near future. They were unique specialists. And this new company that acquired Sunshine's business is now unprofitable. It receives money from the regional budget to cover its expenses, including sponsoring the local community.

\section{Concluding Remarks: Vortex of Trust}

The trajectory of searching for trust in Russia can be graphically depicted as a vortex: winding around a centre, coming closer to it with each round until one is swallowed by the centre. Once we met Dima, at a point when Sunshine was at its brightest, and were surprised by the shadow of pessimism in his 
eyes. We talked about it with one of his friends, and he answered that Dima could not go further, that the development of Sunshine had reached its limit and it was obvious that the end was coming, even if not so soon. This was not about the limit of capital for investment; this was not about the limit of ideas for expansion and change; this was about the limit of trust, as we realized later. If Dima did not have to establish relationships of trust with Chinese buyers, knowing from the start that they operated in different worlds and that the only thing that he could do was apply to their affects and emotions, leaving them to compete with each other for their stones, his relationships with competitors and partners on the Russian side of the border were always determined by trust, namely the decision to take the risk to trust people, accept the chance that in future they will not be loyal, but still seek out contacts with them.

Searching for a person you can trust means searching for the one that will make decisions in the future to help you or to attack your enemies. This means that the person should be autonomous. As soon as you realize that his or her actions depend on decisions sent from above, you cannot trust that person. As a result, in a hierarchical political system the process of searching for trust is like climbing a mountain, when as soon as you reach the top you realize that this is not the top, but just another platform from which you can see another peak. In the end people can trust only one person, the President, because he seems to be the only person who decides completely independently. As a result, even such a small problem as competition for a small, peripheral business becomes an issue needing a letter to the President and a plea for his personal involvement. And whoever reaches him first becomes the winner. This has an unexpected effect on the way the Russian-Chinese border is perceived. Although geographically it is far from the centre in Moscow, in practice this border is created in the capital where the Kremlin decides who has the final right to speculate on the gaps in values created by this border and who can cross it. This does not mean that such decisions necessarily provide legal status for a business, as we can assume that the flow of illegal and smuggled jade has not lessened since the liquidation of Sunshine. Because crossing the border is an activity based on trust-protection, and the epicentre of trust is situated in the Kremlin, both legal and illegal border crossing are negotiated there.

Every time we visited Sunshine, we met new people there. We were surprised, wondering why, if Sunshine was obviously offering such good working conditions with fair salaries, people were leaving it. It turned out that almost nobody could avoid jade fever. They were taking risks to steal stones and sell them directly to Chinese buyers. So the feverish 
affect initially associated with Chinese customers had spread to people from the other side of the border. We recognized that Sunshine could not trust its own workers. Trust was a projection onto those who maintain higher positions, not onto your subordinates. So it always took the form of subordination, rather than a relationship with equals. And this is the main difference between trust as interpreted in the West as described by Gambetta and colleagues, where trusting is associated with the relations between equal autonomous partners, and trust as it functions in Russia, where it becomes an intention, rather than a decision. As we can see from the story of Sunshine, partners in Russia trust not those who are closer to them, but those who are closer to the centre of the system. Thus the search for trust recreates power divisions between the periphery and the centre.

\section{Bibliography}

Gambetta, Diego (ed.), 1988. Trust: Making and Breaking Cooperative Relations. New York: B. Blackwell.

Grasseni, Cristina, 2013. Beyond Alternative Food Networks: Italy's Solidarity Purchase Groups. New York: Bloomsbury Academic.

Keverne, Roger, 2010. Jade: With over 6oo Photographs ofJades from Every Continent. London: Aquamarine.

Luhmann, Niklas. 1988. Familiarity, Confidence, Trust: Problems and Alternatives. In Trust: Making and Breaking Cooperative Relations, edited by Diego Gambetta, 94-107. New York, NY, USA: B. Blackwell.

Miyazaki, Hirokazu, 2013. Arbitraging Japan: Dreams of Capitalism at the End of Finance. Berkeley: University of California Press.

Volkov, Vadim, 2002. Violent Entrepreneurs: the Use of Force in the Making ofRussian Capitalism. Cornell: Cornell University Press.

Wilson, Ming, 2004. Chinese Jades. London: V \& A Publications. 


\title{
The Emergence of Cross-Border Electronic Commerce
}

\author{
Creativity and Declining Trust
}

Natalia Ryzhova

Humphrey, Caroline (ed.), Trust and Mistrust in the Economies of the China-Russia Borderlands. Amsterdam: Amsterdam University Press, 2018

DOI: 10.5117/9789089649829/RYZH

\begin{abstract}
One of the major social changes over the last two centuries has been a 'double alienation': the alienation of the producers when they ceased to own the means of production, and then the alienation of the consumers, who no longer needed to have trusting relationships with the sellers. This chapter argues that we now live in a time of new and even greater alienation. Electronic platforms like Taobao or Amazon offer the purchaser economic exchange without 'real' money, without 'real' interactions with the seller, who may be located anywhere on the globe, and, more importantly, with alienated virtual goods (the buyer purchases her commodity without having any 'real' touch of it). What is the implication of this expanded alienation - will it have a strong effect on trust and social relations? To answer this question, the author addresses ethnographic materials collected among consumers and Internet mediators in a provincial Russian city on the border with China.
\end{abstract}

Keywords: economic culture, social changes, trust, alienation, the state, e-commerce, cross-border exchanges, Russian-Chinese border, Taobao

Graduation balls in Russia involve both the students and their parents in negotiating many highly complicated tasks. One particular headache that must be solved if the evening is not to turn into a disaster is finding the 'dream dress'. All kinds of cheap and not-so-cheap boutiques, on-line shops, seamstresses, and special fashion houses are at the girls' service; since flights from Moscow have come down in price, some people even 
try Italian and French department stores. But access to such consumer delights is not equal: it depends not only on the parents' purse but also on geographical location. Graduates in Blagoveshchensk, the administrative centre of Amur Oblast on the Chinese border, have nothing like the advantages of Muscovites. The dress your neighbour wore last year is hardly an attractive proposition, and buying something in local shops is likely to lead to a catastrophe: two or three identical dresses at the same ball. As for flying to Paris or Milan, when you first have to cover the thousands of miles to Moscow that would be completely exotic and entirely out of the question. True, the nearby border suggests another possibility: buying a dress in a Chinese border town. But this does not satisfy the modish girls of Blagoveshchensk - for in Heihe, the adjacent Chinese city, they sell 'Chinese models'. Of course, the 'dream dress' sold in Milan or the 'right' Moscow store may actually be made in China. The difference in quality perceived by my young purchasers lies not so much in where the dress was produced, the brand, or the quality of the material, cut, or stitching, as it does in a feeling that is difficult to rationalize, a perception of 'Chinese-ness' linked to 'cheapness' and bad taste. These are not professional or regular buyers. Therefore, their idea that they do not want to buy from 'our nearby China' or a 'cheap fake' does not contradict their happy willingness to acquire a Chinese replica of a Carla Ruiz or Tarik Ediz. The basic question is: where to find this lovely replica?

Relatively recently, to the satisfaction of the fashion-conscious girls of Blagoveshchensk and to Russian consumers in general, it has become possible to search for one's 'dreams' in Internet shops. An endless array of goods and brands is now presented to people at home. This is not just a matter of more choice and a different trade format; it is a technological innovation that is changing the known world for the inhabitants of the Russian hinterland, altering everyday interactions with machines and technology, with other people, time, space, and institutions - especially state institutions. This innovation is even changing how people think about or conceptualize the state, as well as the relationships between states. This chapter is devoted to an explanation of these changes.

My ethnographic materials were gathered in summer 2014, spring 2015, and summer 2016; other data was acquired often by chance from various sources between 2014 and 2016. Inhabitants not only of Blagoveshchensk but also Vladivostok told me about their Internet purchasing habits, mostly from Taobao, the platform most relevant for my research. In addition to meetings with mediator-entrepreneurs working through Taobao and their regular and occasional clients, I spent several days in the offices of my main 
respondents, observing how they hold consultations and conclude deals, discovering which questions worry clients and how problems are solved.

Though there must be many ways to anthropologically describe the changes brought by Internet trade, it seems to me that the concept of trust provides a logical and interesting angle on these social transformations for many reasons. One main reason is that the people themselves constantly used the words doverie ('trust') and nedoverie ('mistrust') when trying to explain their choices, decisions, ways of calculating, and acceptance or avoidance of risk in online purchasing. The issue of trust and calculation will be the subject of the third section of this article.

The term doverie has particular meaning for the online sellers and middlemen, both large and small. To judge from their publicity literature, acquiring the trust of the consumers is Task Number One. Professional opinions constantly underline how difficult it is to 'conquer' the client's trust and how easy it is to lose it. At the same time, there are many assertions that trust is a pragmatic matter, an almost material and working agent that can best be created by the correct use of technology. Variants of this special 'trust-evoking' and 'trust-forming' technology are used by the entrepreneurs of Blagoveshchensk to develop their online businesses linked to Taobao. This 'special technology' will be the topic of the second section of this article.

It is clear that the everyday language of trust used by consumers and small middlemen differs from the specialized discourse of IT-experts and management gurus with their professional use of the term. And these various usages differ from the way that trust is conceived by social scientists. So why, when the main theme of this article is social change, have I chosen to use trust as the 'mirror' of these changes? The answer to this question constitutes the first section, beginning with the contrasts between economic and sociological approaches to trust. I then proceed to explain why an anthropological viewpoint can best grasp the influence of technological innovation on people's ideas about whom and what they can trust - a shift that then leads to broader transformations in society.

\section{Trust and social change: where does the strength of anthropology lie?}

The concept of 'trust' has been actively debated over the last thirty years, especially in economics and sociology, and to a lesser extent in anthropology. Adam Smith long ago underlined that the main goal of man is not to improve his prosperity; rather, the desire for glory and the wish to convince 
and direct people, and evoke in them a feeling of trust, is one of the strongest human passions (2002). But economists largely ignored Smith's ideas on sentiments; the more mathematical the discipline became, the less moral and the more calculating became 'the human subject'. The situation changed with the advent of institutional economics. Naked rational choice was then dislodged from its pedestal and trust appeared among the parameters of economic models. Neo-institutional economists agreed with sociologists that cooperative behaviour was impossible without trust, and that the lower the general level of trust in a society became, the higher the transaction costs (in obtaining further information, controlling the transaction, and so forth) would be. High transaction costs would correspondingly reduce the effectiveness of the economy - there would be less investment, fewer transactions, and a slower rate of growth (Williamson 1993) Hardin 1991; Knack and Keefer 1997; Uslaner 2005; Tabellini 2008). Economists showed statistically that nations with a higher level of generalized trust ${ }^{1}$ enjoyed higher levels of social capital and did better than nations with low levels of trust. Of course, there were criticisms of this model, including its selffulfilling character; there were also questions about how trust could be measured, and the vulnerability of the data derived from questionnaires. But for my argument the issues of measurement are not as important as the fact that economists use this social construct (trust) as a datum, borrowing it wholesale from sociology, without trying to understand its nature or the reasons it might change.

For many sociologists trust is the 'routine basis of everyday interaction' (Misztal 1996, 97) and necessary for maintaining the stability of social institutions (Sztompka 1999). In the absence of trust, each time a decision is taken the individual must survey the whole variety of possibilities and risks, which, according to these theorists, leads to the impossibility of social interaction at the individual, group, and institutional levels.

In the mid-2oth century, and particularly after the 1970s, sociologists began to see trust as a 'substitute' for religious ethics and the institutionalized faith that had played such an important role in stabilizing society for Durkheim (1995). This substitution required a differentiation of the roles of rational and irrational knowledge in forming trust. Sociological opinion was soon divided. Some, refusing to recognize a particular role for religious faith, insisted that the stability of society is guaranteed by irrational feelings (Simmel 1950), or by the rightness of abstract principles (Giddens 1990).

1 'Generalized trust' refers to the common level of trust in the society: the degree to which people trust unknown others or people as a whole. 
Fukuyama argued that trust is an element of traditional society, and that the laws and economic rationality that would support a stable existence in post-industrial society would depend on the kinds of traditions that had formed in different societies (1995). If we are to believe Fukuyama, the flourishing of society depends on certain cultural traditions of trust/ mistrust, which essentially remain unchanged over time.

Opposed to this view is a different group of sociologists, who maintain that trust rests on rational knowledge about making decisions with regard to risk in given situations of uncertainty (Luhmann 1979; Coleman 199o). Trust for these sociologists is a question of rational choice among alternatives in conditions of uncertainty and the calculation of one's own actions. Sztompka (1999) asserts that trust is a bet on how others will behave. Seligman (1997) underlines that trust in this sense is a contemporary phenomenon, corresponding to the way the economy and society are now organized.

These two apparently opposed approaches can be reconciled relatively easily if we accept the idea that in more developed societies trust takes the rational-calculative form, while in traditional societies it depends on less rational beliefs about the motives of known people. Consequently, the radius of trust in traditional societies tends to be limited to close people and kin. With the expansion of economic relations, exchange, and trade, the radius enlarges and at the same time there is a process of rationalization - people do not trust 'blindly', but only on the basis of knowledge and the possibility of judging the degree of risk in undertaking an economic exchange. This way of distinguishing societies is based essentially on the borrowing of ideas developed in economic anthropology about the correlation of reciprocal - as distinct from commercial - exchanges with the two different types of social relations. James Carrier, for example, discussed the emergence of double alienation as social relations changed over the 19th to the 2oth centuries: first there was the alienation of the producers, when they ceased to own the means of production, and then there was the alienation of the consumers, who no longer needed to have personal trusting relations with the sellers (Carrier 1995, 1997).

It is difficult to imagine a greater alienation of the consumer from the producer that that found on the electronic platform Taobao - even more than when ordering online from retail outlets. In the latter case, the purchaser does not interact directly with a seller, since she places orders through the 'alienating' Internet, but she can still phone the shop and speak (albeit through the technology of the telephone) with another human being. Such a virtual retail outlet is, in a way, a continuation of the physically existing shop that the consumer often already knows. For example, when buying 
online at Marks and Spencer it is common to compare the experience of choice in the familiar shop with that on the monitor screen at home. But an electronic platform is a different matter. It connects the purchaser with an absolutely unknown seller, who may be located anywhere, even thousands of kilometres away, and is more imaginary than anyone who exists in the buyer's physical world. Even more alienating, it is not just the seller but the object ordered that can only be imagined - it exists in the future. With an electronic platform, the consumer has to trust in the existence of a 'shop' she does not know and in the existence of imagined things...

Does this mean that this alienation, which alters social relations and extends the 'radius' of trust to a vastly expanded sociality, makes trust more 'rational'? Having gotten rid of person-to-person relations, does it substitute them with person-to-machine relations? Do the links become more tenuous as a result of the extension of this radius? Answers to these questions cannot be discovered in terms of the rational choice-versus-trust dichotomy. An anthropological approach demands a more flexible and broader conception of trust, namely, as a multitude of discursive ideas about the acceptance of risk that are defined, organized, and re-organized by people's interactions with things, ideas, and spaces that are ill-understood and physically or temporally distant from them.

\section{Taobao: earning money from trust}

The Alibaba Group, ${ }^{2}$ whose central office is located in Hangzhou (China), comprises 25 strategic businesses, including Aliexpress (retail and small wholesale trade), Alibaba (electronic platform $\mathrm{B}_{2} \mathrm{~B}$, business-to-business trade), Yahoo (search engine), Alipay (payment platform), Taobao $\left(\mathrm{C}_{2} \mathrm{C}\right.$ platform, consumer-to-consumer trade), and others. In 2015 Alibaba officially opened trade in Russia and immediately took the leading role in Internet business in the country. 'Alibaba is 800 million named goods. I can't even imagine such a number. In Russia eBay has 150 million things, and Wikimart has only 2 million, though we think we have the greatest assortment. But that 2 million is a drop in the ocean by comparison with what Alibaba offers. There aren't that number of goods in Russia'. ${ }^{3}$ According to sociologists' polls, consumers outside Moscow, St. Petersburg, and the western parts of the country hardly know about Yulmartov, Wikimart, or Yandex Market (the 
main Russian internet companies). The basic Internet business for them is Alibaba (in the form of Aliexpress or Taobao) and the various intermediary firms that enable them to make purchases on these platforms.

In Chinese the name Taobao means 'search for treasure' (tao 'search', bao 'treasure'). In the official name there is another syllable, van ('network, site'). The company's slogan is: 'You may not find the treasure, but don't lose trust' (Tsin Yun). In other words, Taobao is giving out a signal: trust in us and you will find your desired treasure through the Internet. So what kind of business is this that sells trust?

Taobao is a website, a platform that provides information about goods offered by tens of thousands of electronic businesses in China. It was founded in 2004 on the $\mathrm{C}_{2} \mathrm{C}$ principle, i.e., consumer to consumer trade or trade between economic agents who are not entrepreneurs in the judicial sense of the word. Other classic examples of the $\mathrm{C}_{2} \mathrm{C}$ model are sites advertising the buying and selling of second-hand goods or books, or the renting of flats. Taobao is also a site that advertises sales by setting up auctions (the prices depend on the balance of demand and supply). In 2011 the general director of Alibaba Group announced that Taobao would divide into Taobao Marketplace, where goods would be sold as before by unregistered sellers, and Tmall, which would group together proprietary firms and officially registered retailers. What was hidden behind this division? Did the separation of state-registered and unregistered firms really indicate a difference in quality? And did this mean that the state was the guarantor of trust for Alibaba?

Taobao's income, like that of most of the other Alibaba companies, comes from the commission charged for carrying out various intermediary activities. The services offered are not so much about informing the buyers and sellers about one another, as they are about getting the goods moving, guaranteeing payments, resolving conflicts, and proffering 'trustworthy information', including about the reputation of firms. This is in fact the cornerstone of the business. 'Reputation' is made up of many parameters, and although Taobao tries to register it quantitatively (by providing ratings on the pages of sellers, their number of sales, and customer responses), it cannot be said that reputation has been fully separated from the actual goods. As before, people trust the brands sold on Tmall. The value of these brands includes the fact of state registration of their trademarks, and therefore logically - and profitably - there is a separation of the firms that have managed to capitalize the trust in their brand from those that have not been able to do so. For Alibaba, the mere fact of state registration is not as important as the fact of the capitalization of trust, which is what it in practice trades. This is confirmed by the fact that on the Taobao Marketplace 
site, as an any bazaar in Russia, you can find not only the goods of officially registered firms but considerably more amateurishly made and fake goods, sold by people who are legally bazaar traders - having neither registered their business nor officially opened a retail outlet.

Although the official opening of Alibaba was in 2015, Russian citizens had been buying goods on Taobao for a long time. To do this, various creative tricks and 'business schemes' were necessary. As Alibaba had probably not initially intended to set up cross-border trade, a Russian purchaser had to have a Chinese mobile telephone number in order to register. This meant that only people who could set up a contact with a Chinese citizen and make him their means of accessing the gigantic virtual bazaar could actually buy anything. And indeed these people became the first mediators in Russia, gathering orders from other consumers - first their kinsmen and later anyone.

It is difficult to say now who first dreamed up the idea of founding a business on this basis - maybe there were many such people. But in Blago, which is divided from Heihe only by a river, the number of mediators providing access to the Chinese Internet-bazaar has risen exponentially (see Figure 17). This was helped by the fact that many locals had Chinese simcards anyway, due to the widespread development of the shuttle trade across the border.

Of course, the fact that mediators had the right mobile phone was not the only reason they were necessary. Another barrier for ordinary consumers was that Alibaba demanded payment through Chinese credit cards (only those who had access to Chinese payment systems could register an account, and hence buy anything). Then there was the fact that, although a Chinese phone number and credit card would enable a purchase, it would not help you actually receive the goods. For that, a postal system connecting the Chinese producer with the Russian buyer was necessary. But Pochta Rossii, even 25 years after the fall of the USSR, is still the same old 'Soviet' postal service. Post offices of course exist in the tiniest and most remote settlements - even in places where there is no other evidence of the state: no police, no school. But this is a highly centralized structure. The great majority of dispatches from abroad go first to Moscow and then trundle in a postal wagon slowly to the oblast (regional) centre, and then - after a pause for sorting - to a district station, and then by car to some village in the middle of the taiga. Parcels, in truth, are only rarely entirely lost. But they can take an extremely long time to arrive: the ball may have come and gone, with the graduate still waiting for her dress. Furthermore, this centralization affects the price of delivery, eating up a significant part of the total cost. In recent years Pochta Rossii has been gradually addressing its clients' 
interests. But being a quasi-Soviet organization, i.e. very bureaucratic, this is not happening very speedily at all.

The consumer has another option: choosing an international delivery service such as DPD or DHL. But their organization again repeats the centralized logic - the goods first have to go the distribution centre, which in the majority of cases is Moscow. From there, the high and - by comparison with Pochta Rossii - prohibitive cost of delivery makes the whole undertaking of buying on the Chinese Internet pointless.

This situation changes daily; it is possible that before this article appears some international postal service will have set up a branch on the China-Russia border, enabling goods to travel directly to Siberia without first having to go to Moscow. But they would still have to get the customs service to agree to open a checkpoint for goods at this new reception site. In fact, the competition between delivery services depends on the customs service. According to law, one person may receive foreign goods duty free only up to a value of 1,00o euros in one month, the total weight of which should not exceed $31 \mathrm{~kg}$. Furthermore, this person must guarantee that these goods are for personal use. It is the customs service that has oversight over these regulations. The presence of customs right at the sorting office greatly speeds up the procedure; otherwise, goods from abroad are delayed by having to sit in customs warehouses waiting to be 'cleansed' from duties before they even go into postal sorting.

All these complications of delivery from abroad can be avoided in only one way: the unofficial channels set up by the cross-border shuttle trade. These channels, like the trade in general, are a 'grey zone', but are constantly transforming. In Blago, where our graduate is waiting for her party dress, the shuttle trade has been flourishing since the late 1980 s, is embedded in local life, and not to use the well-honed schemes 'would be a crime' against the girls and their parents. The simplest scheme is fake 'tourism'. A Blago resident with only a passport - a visa is not necessary for a 4-hour visit to Heihe - can go there, collect a parcel from an intermediary (the possessor of a Chinese credit card), pretend that this $30 \mathrm{~kg}$ bundle is goods for her personal use, return to Blago and give the parcel to the person who ordered it. The same scheme also works for people who order on the Internet.

Returning the question of trust, I again emphasize that in 2010 the Russian consumer wanting to buy something on the Chinese Internet found herself in a situation of a total lack of trust. The Russian state, in the form of the customs police, lacked trust in the consumer and imposed limitations on the value and frequency of Internet purchases. The Chinese did not trust her either, and required a Chinese phone number and access to a Chinese 
payment system. A Visa card issued by a Russian bank, even with a million dollars in the account, did not constitute creditworthiness according to the Chinese company.

All of this helped bring about the emergence of specialized mediators. They gathered all of these capabilities into one operation (phone, card, and shuttle delivery), and thus helped the customer overcome the lack of trust in her from both the business and the state. At they same time, they helped the customer overcome her own suspicions of the virtual and distant Chinese bazaar. In other words, not only Taobao but also the mediators made their profit out of creating trust, as the following examples show.

Mediator Case 1: ' hobby as business'. Yevgenyi, 27, studied informatics and computer engineering, and when we met in 2014 he was the owner of a small business in Blago. He rented a small office ( $3 \times 5 \mathrm{~m}$.) in one of the business centres in the town where he had Internet access and could make the necessary contacts. His business consisted of helping customers find goods on Taobao, and after the choice was made receiving the payment, transferring it to his Chinese partner, and then organizing the shuttle-method delivery. His business idea originated from three personal aspects of his life: his hobby (he loved spending time on the net), his own desire to buy things, and his old contacts in Heihe (as a student back in the 2000 s he had taken part in shuttle deliveries). Like his clients, Yevgenii started by buying the cheapest and simplest things, only gradually increasing his 'stake'. Then his friends and relatives noticed how clever his purchases were (for example, he would buy a pair of reading glasses exactly the same as those in the shop but ten times cheaper), so they asked him to buy something for them as well. In this way, a circle of trust formed. Yevegenii did not sell his services, but instead took part in a complex system of reciprocal exchanges, and as a result his relatives - who in general did not trust the Chinese Internet - trusted him and his experience. The sum they handed over to him each time (i.e. invested in a purchase) was in some sense a quantitative evaluation of this experience, or a rationalization of the trust placed in him. After six months of this 'capitalization of trust', friends began to ask Yevgenii why he did not want to sell his experience for money to other people - not to the usual relatives and friends, but to acquaintances of acquaintances.

How might the terms 'rational' and 'irrational' apply to this situation? The circle of relatives' trust was not only based on an irrational belief in Yevgenii's good intentions. They also made calculations about his purchases for them and on that basis understood the extent they could trust his experience. They would also proceed on an experiential basis: 'today I'll 
buy a mobile phone cover for 100 roubles, in a month I'll get a simple phone for 1,00o roubles, and only after a year will I take the risk of ordering an iPhone 6.' This rationalized trust also relied on reciprocal relations: the understanding that Yevgenii would not run away with the money, and that a tangle of connections tied him to this town and this way of life. One of his first clients told me:

I trusted his experience of course. But it wasn't that I thought, 'It'll work out, or it won't work out.' When I decided to buy some furniture through him and laid out a considerable sum of money, somewhere in the back of my mind I knew that this town of ours is not large - I can always find him. After all, would he run away from his wife, his flat, his business? Of course I knew that not everything depended on him. But still, he has a strong interest in doing everything as well as he possibly can.

At the same time, the newness of the electronic technology and the impenetrability of the Chinese Internet-bazaar interface meant that all participants in the trade had to have some blind, irrational faith. At this point Taobao operated only in Chinese. In fact, the ability to read and translate 'Chinese gramota' was another reason (along with the payment card and mobile phone) for the emergence of mediators. Having decided to expand his circle of clients, Yevgenii created a website that explained how to make a purchase on Taobao and, having some computer competence, he was able to connect it to the Taobao site. In practice this meant that his links on the site were basically a promotion of his own business, as the clients could only choose things he had already found. He would first find, for example, the best sellers of iPhone 6, advertise links to them, and his clients could then buy from these pre-selected sellers. The assortment and price - that was the very limited work done by Yevgenii. So when I mention 'blind faith' I have in mind that many of his clients did not really understand, and did not try to investigate, exactly what service he was doing for them. They were not even interested in whether Yevgenii himself knew Chinese. And it is indeed surprising that he does not, in fact, speak, read, or write Chinese. His entire work is based on another technological marvel: Google Translator.

Why did the clients agree to trust such a middleman? How could they trust their money to someone with so little professionalism and over whom they had no real control? Why did they not try to find out about the technological specifics, enquire about his knowledge of Chinese, or discover how the system works in general? Of course, the more money they pay, 
the more questions they tend to ask. But even so, the main questions are straightforward. The question of how the ordered item will get across the border is much more likely to arise than the question of how the order will be processed in China. But doesn't the absence of any questions about how much Yevgenii himself understands about these distant matters suggest that the clients are too trusting - maybe even that they are 'irrational', 'non-market', traditional folk? Who in their right mind would trust their hard-earned money to someone who doesn't even know Chinese?

In answering these questions it is interesting to recall Latour's $(1987,180-$ 181) remark that if you meet an accusation of irrationality all you need to do is to alter the angle and length of the network investigated. Imagine a Western consumer deciding to buy something online: does she really understand how the various black boxes work? How the worldwide web works, and what TSP/ IP protocols are? I think it is highly unlikely. Of course, much depends on her level of education, and the probability that, understanding something of the whole process of purchase, she will simply refuse to be buried under the mass of information that accumulates around even one small purchase. The difference between the Russian client buying from Taobao and the American buying from Amazon lies in which information they think can be discarded. Ridding herself of surplus information, the buyer relies simultaneously (to a different degree in different situations) on a concrete human and on a non-human being, as well as on the institutions that order the rules of the game that ties people and non-humans into one network.

Mediator Case 2: Enlargement of the horizon. Viktor and Andrey are brothers, aged 25 and 33 years old; Viktor speaks Chinese and Andrey is a genius with computers. Unlike Yevgenii's small business, when I met them in 2014 their firm was oriented to a different scale. They tried to minimize personal connections (which Yevengii at the time was still relying on) on the grounds that they take up too much time and effort and therefore limit the possible amount of profit. If Yevgenii's technical innovation was to create links to previously selected goods, Andrei's innovation was a browser that could also respond to the purchaser's inquiries. Furthermore, clients using the brothers' site could search for the desired item in Russian. Thus the brothers economize on time and transaction costs. Their basic idea is to transform personal trust into impersonal trust by means of the purchaser's trust in the machine.

Mediator Case 3:Russian bridges. The above example of an intermediary is no exception: a Google search reveals many Russian reincarnations of the Chinese Taobao, Aliexpress, etc. Some of them are technologically similar 
Figure 17 Advertisement for a company offering help with on-line purchases in Manzhouli, China

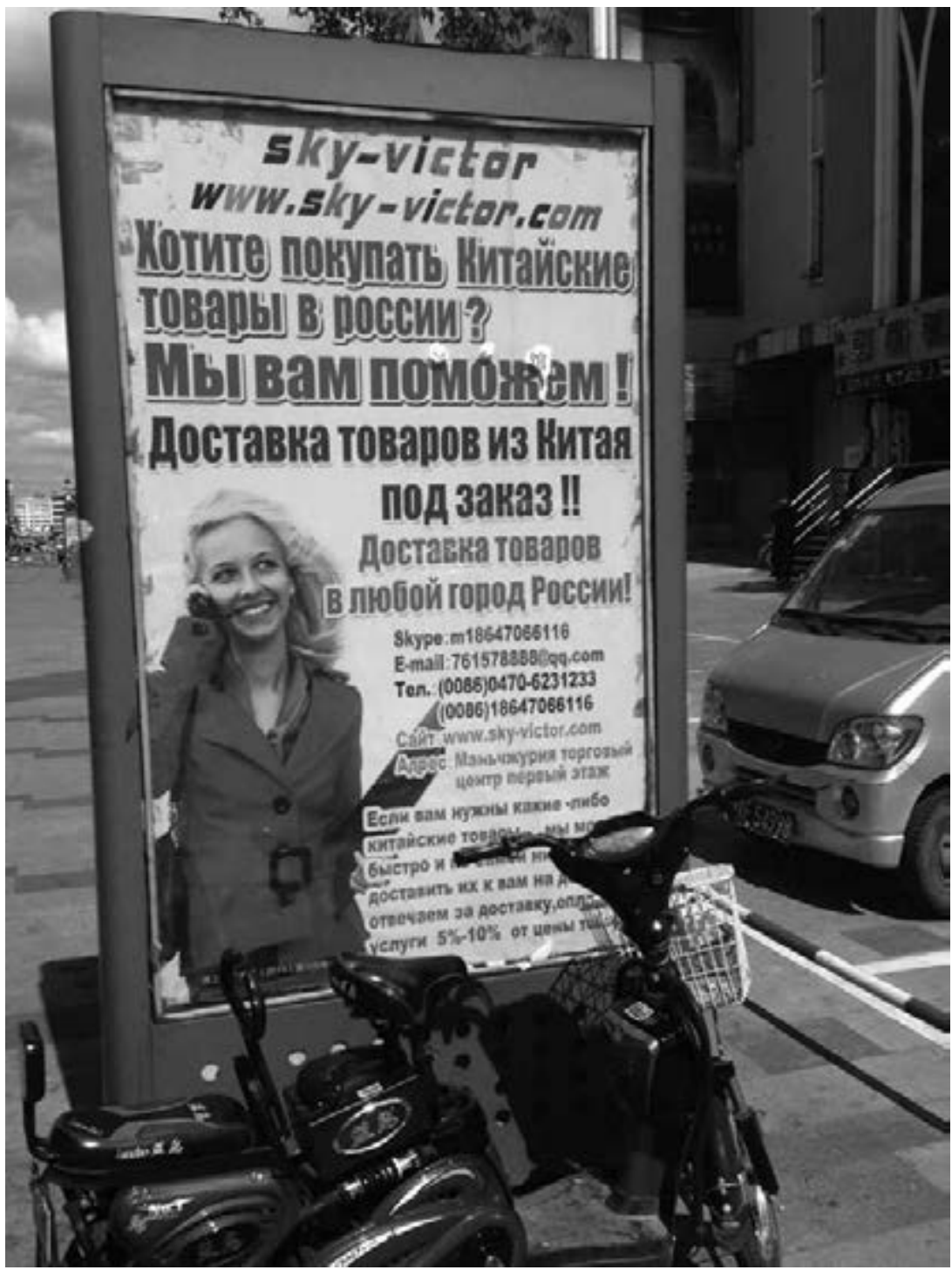

to the brothers' invention (i.e. they are mediators between Russian purchasers and the Chinese bazaar), but some are more similar to the technical architecture of Taobao itself. For example, the company 'Russian Bridge' simultaneously offers online shopping on Taobao and other means and 
forms of obtaining goods from China. They have their own warehouse in China and advertise that they can supply even cheaper goods than Taobao. This is possible, they say, because of their direct supply routes and the physical presence of the goods in the warehouse. In practice however, they simply go to producers who are overpricing and ask them for a discount. This kind of firm is using the trust of the shoppers in the assortment and prices on Taobao to insert themselves into and grow in the market.

Consumers these days know about the existence of different kinds of mediator firms and are forming their own networks, their own systems for constructing trust. This very often works via blogs and forums on which consumers share their knowledge, perceptions, doubts, and experience of buying things directly on Taobao and on its substitutes. Thus, through the mediation of non-humans, the new technology is forming virtual communities of people who have never seen one another, and whose entire interest in communicating with one another revolves around the goods.

According to Latour (1987), analysis of technograms enables the understanding of social relations and vice versa. Taobao, and its substitute created by the two brothers, are excellent examples of things that are simultaneously techno- and socio-grams, in which the 'simple purchasers' - for Taobao, Yevgenii, Viktor, and Andrey are no more than that - are in fact not at all simple. While living their usual lives, they also become mediators and fundamentally change the original technological idea, as well as the company's model of constructing trust. The owners and designers of Taobao invested huge resources into creating the ideal 'black machine' that could guarantee secure transactions to all of their clients. However, ordinary people, even those who live in distant Blagoveshchensk, have their own ability to re-construct the black box according to their own needs. Thus technology changes along with people, while people (including their ideas and means of constructing trust) change along with the technology. So how is it that alienation comes to be the result?

\section{E-Trade: how trust is alienated}

The virtual reality of the Internet is an everyday reality for a huge number of Russians. According to Internet Live Stats, 102,258, 256 users were registered in Russia on 1 September 2016. The percentage of usage was 71.3 percent lower than the USA or Japan, but higher than Italy and comparable with Israel. Among the younger generation of Russian citizens the figure is even higher: over 95 percent of young people are Internet enthusiasts. The advent 
of mobile devices (phones, tablets, etc.) gave a particular boost to access. According to research on the 'Generation of the New Millennium' conducted by the Social Opinion Foundation in 2014, 74 percent of those polled said that without the Internet their lives would change markedly.

A sociological poll (e-Commerce User Index 2014) carried out by GFK established that online purchasing is expanding among the population according to the size of the city (in Moscow the share of online customers is over 80 percent). The difference can be explained, according to analysts, by the later spread of the Internet to smaller cities (in comparison with larger ones) and by the relatively low level of Internet service in these places. The supposition that smaller towns have lower levels of service looks very logical, if we think about the vast size of the country and the ideal of the 'sterilized' development of Internet trade. Among other things, this ideal image includes payment for goods online, which excludes many risks, and the delivery of goods via the official post service, whose accuracy, punctuality, and reliability should be guaranteed by its many years of functioning. In Russia, however - and here it is irrelevant whether we are referring to large or small cities, to those closer to Europe or those near Asia - people usually pay in cash to a courier, a person who often also supplies parallel (informal) methods of delivery, and not the official postal service.

Here it is interesting to consider how people talk about trust. A very realistic picture of internet trade was given by the founder of the large Russian internet company Wikimart, M. Faldin: 'At the present stage of development, the goods are delivered by dim young men in black sports caps or by slovenly-dressed asocial personages of middle age. They hurriedly pick out the goods you ordered from huge bags, take your heap of grimy notes in cash, and quickly disappear, hardly even saying good-bye, and certainly not bothering with a receipt. ${ }^{4}$

My respondent Zhenya (in Blagoveshchensk, summer 2015) said:

I sometimes order delivery at home, but more often at my office - well, a sort of office - it's just a small room where everything is dumped here and there... But it's cheaper in the office, because you have to pay for delivery. Of course, the price is the main thing. In a shop you could try the item on and this way that's impossible, and if you try to send something back there's a heck of a palaver... so basically you just have to trust that when you order the goods they'll be what will suit you. 
[Q: And what does 'to trust' mean?]

To trust is to rely on avos' ['it might work out for me' - see Humphrey, this volume].

[Q: Does anything back up this faith?]

Well, if you go on ordering through the same site, over time you come to understand whether it is a good shop, and you go on buying there. You read blogs, people tell one another 'those ones didn't let me down' and so you think it will be all right for me too. But if someone writes that they were cheated or their parcel took far too long to arrive - well, that's it, finished, no one will trust that firm.

[Q: And are there any ways to strengthen trust?]

I think that in ordinary shops there should be some kind of guarantee or receipt, i.e., you come back with a receipt, a paper, and it's fine, they'll exchange the goods. If you lose the receipt - forget it. But here on the Internet there's none of that. Absolutely no receipts. Well, of course you can't count some Chinese chit attached to the parcel! With just that chit in hand, you'll get nowhere with the zashchita..$^{5}$ In general, I never rely on receipts - it's just a waste of time; which official is ever going to help you put a salesman in his place?

Before assessing how the idea of belief-in-avos' is intertwined with contrasting ideas about trust as fixed by a receipt, it is first necessary to provide some information about the peculiarities of electronic trade in Russia in general and in the borderlands in particular.

The absence of a receipt for payment is a clear indication not only of the informal channels of delivery but also of the fact that the companies in this business in general prefer to remain 'in the shade'. As Faldin said,

In Russia, the entire 'white' [i.e. not infringing current legislation] Internet trade is loss-making. To establish a profitable internet-retail business you need five to seven years and $\$ 100$ million dollars. There are no miracles. The shops that appear at your door and sell goods without a receipt - are profitable. The loss-making ones are the large retailers with a turnover over $\$ 50$ million working in the white. ${ }^{6}$

5 This is a special state organ responsible for 'protecting the consumer', i.e., the observation of consumer rights according to present legislation in the retail trade.

6 https://snob.ru/selected/entry/9o635 
Even companies that Faldin describes as working 'in the white', also sell goods that have not been certified in Russia. This means that they were legally produced and legally imported into Russia, but no certificate was issued for them, as a rule because the producing company had not signed an agreement for them to be brought into the country. Such retail business in uncertified goods is formally forbidden, and therefore one can say that the entire Internet trade is the subject of weak attention from the state.

It seems that the degree of inattention varies from company to company. A particular case is counterfeit goods, i.e., copies to some degree resembling brand goods. Degrees of 'greyness' and various methods of reducing costs affect retail strategies. In principle, companies 'in the white' import goods legally and pay all taxes and duties when they cross the border. But in fact, this is far from the case, since numerous schemes for getting round customs legislation are well known, not only to experts but also to daily users. ${ }^{7}$ Still, the trans-border Internet trade takes place in an even greyer zone. This relates to the rule that only private persons have the right to buy goods abroad 'for personal consumption' without paying customs duties. But the existence of this possibility it very attractive to entrepreneurs, who use it actively. Infringement of any of the rules risks a fine, but also brings big profits. The trans-border Internet companies also introduce their own tactics for lowering costs and getting round customs duties. For example, the 'Aliexpress Po-Russkii' site has a page with the title 'How to avoid customs'. The same topic occurs on numerous other cross-border trade sites and blogs, and this is absolutely not by chance. The low prices are possible partly because of economizing on customs and partly because of counterfeits.

In 2015 around 155 million parcels went through Pochta Rossii (7 percent more than in 2014); the value of all Internet trade was USD 10.5 billion, and its trans-border segment rose to USD 3.4 billion, of which 80 percent came from China. In that one year, the Customs Service discovered 14,200,000 counterfeit items - almost 50 percent more than in 2013 and $2014 .{ }^{9}$ But, as I have explained these goods do not only arrive through Pochta Rossii- and in this business there are now various mediating structures and schemes that have taken over from the shuttle trade.

Realizing the scale of these infringements, at the beginning of 2016 the Customs Service announced that it would open every 2oth parcel arriving

7 https://ria.ru/politics/20160728/1473071167.html

8 http://aliexpresses.ru/aliexpress-kak-obojti-tamozhnyu

9 According to the assessment of the National Association for Distance Trade and Data Insight; for more details see http:///.kommersant.ru/doc/2895191 
in Russia from abroad for inspection. Though the media mentioned various reasons for this new policy, the main one, according to many specialists, is the fight against Chinese competitors:

The trade platform AliExpress, belonging to Alibaba, has already become the most popular Internet market in Russia, and from June to December 2015 its traffic rose by $120 \%$. In September 2015 AliExpress reached almost 24 million individual users. In this situation Russian online retailers naturally try to bring in measures that will help them not to lose competitive advantage. After all they are scared by the lower prices and wider assortment of Chinese online markets, especially since the quality of their goods is around the same level as their own. ${ }^{10}$

While Alibaba's competitors struggle against the giant in various ways helped by the state in the form of the various sections of the customs - the customers are voting with their hands and roubles for the existence of an accessible Chinese retailer with inexpensive and varied products. My respondent Nikita (Blagoveshchensk, summer 2014) said,

\begin{abstract}
Aliexpress or Taobao means infinite choice. You only have to think of something - even something idiotic like perfumed socks or a be-jewelled dog collar - and go to Taobao and there it is. And the prices are always cheap! [Q: And it doesn't worry you that these goods are Chinese?] Tell me who says that, and where it's a worry. Go to Finland or the USA, and isn't everything there also Chinese? You just should not mix things up - their servers have everything and for different prices. Over there it's not going to be some handmade stuff from Heihe... I'd say it's simply a different China for them. Heihe is simply low quality fakes, but on Taobao you can find the same Gucchi handbag. It may be a fake too, but of such good quality that who's going to get worried.
\end{abstract}

In Russia e-trade is a sector that is opaque to the state, in which a large proportion of the goods come from China. In general, the language of 'nontransparent', 'grey schemes', 'avoidance of customs and other duties', and other such terms are part of official government judgmental discourse. The absence of a receipt as a marker of unofficial character - and at the same time a marker of the fact that a customer cannot approach a state servant for help - differentiates a 'trust' situation in which a third party (the state as 
guarantor) is absent, from one in which 'trust' is calculated and written on a receipt and the customer can turn to the guarantor for help. It is significant that it is the purchaser who takes on this risk. He or she rationally weighs up the price of the 'item with receipt' against that of the 'item with a chit in Chinese', and agrees to the absence of the guarantor-state with its 'consumer rights', police and court. Our consumer does not care about any of that.

And, furthermore, the more rational the consumer (usually when purchases are not for oneself but for a commercial purpose), the more carefully he or she calculates how to avoid or hide from the state. My respondent Ivan, a sixth-former from Vladivostok, who buys goods regularly from Taobao for himself and his classmates (with a little extra charge - 'interest', as he calls it) confided about his schemes:

1 If you suddenly need to order over, say, five mobile phone covers, you can split the deliveries among your relatives or friends.

2 I record an account of the expenses. I enter every purchase and weight into Excel.

3 If you need to send a big consignment, you can separate them into different dispatches.

4 If I send off several parcels I make an agreement with the shop about them arriving at different times. Otherwise, they might all arrive at customs at the same time, and that would be it - I'd have to pay the duties.

5 If I order myself something big that can't be divided up, I ask them to charge for the full value. Otherwise they could get suspicious and I would lose trust.

The conclusion is that the virtualization of trade has become a further step in alienation. This alienation has changed from earlier forms (it is no longer alienation from the product of labour, or alienation of the purchaser from the seller) and goes along with changes in the relation of the consumer ('citizen') to the state. Two intriguing moments are worthy of mention. The first is that the purchasers - though of course not all of them - are conscious of these consumer-state changes and have a rational explanation for them, even to the extent of drawing the conclusion that self-organization works better than the monopoly of violence. My respondent Igor (summer 2104, Blagoveshchensk) said:

A certificate is a kind of protection. That is how the state sets up barriers to trade in goods that are illegal and dangerous to health. But is it really protection? OK, that concrete Samsung mixer didn't get a certificate. 
But aren't there ways of complaining to Samsung anyway? And is this mixer really a danger to life? So what is the state wanting to do with its certification? Does it really protect me? In general, the community that exists through the networks on the Internet, and the way that access to Aliexpress is set up, gives me much greater protection. If you receive a defective or dangerous product everything works automatically - sooner or later that very mixer, yes, and even Samsung itself will disappear from the market...

The second interesting point is that the everyday attitudes toward not only one's 'own' but also 'foreign' states are changing. My respondent Ivan said, 'Well, so what is China? China, unlike Russia, does not want to fleece me. That's where the producer is, and everything is honest. I need those goods. In Russia, not only is there no producer but every day the state thinks up some way to take something away from the consumer.'

\section{Conclusion}

The 'laboratory' I studied in this paper consists of countless actors - the ordinary inhabitants of the Russian provinces, Russian and Chinese creative intermediaries, non-human mediators such as computers, e-technologies, and payment systems, Chinese producers, and global and not-so-global postal systems. They consist of various economic, social and political cultures that confront one another. In the case of Russian-Chinese Internet trade, it is difficult to expect a high level of trust in one another. The people interacting along this border have a long history of mutual alienation and suspicion. But the development of new technology helps overcome these contradictions in a way that is 'ordinary' and not dependent on special expertise. It is not 'high level meetings' but everyday ways of overcoming mundane barriers that enable people to become closer to one another.

\section{References}

Carrier, James, 1995. Gifts and commodities: exchange and Western capitalism since 1700. London: Routledge.

Carrier, James, 1997. Meanings of the market: the Free Market in Western Culture. Oxford: Berg. 
Coleman, James Samuel, 1990. Foundations of Social Theory. Cambridge, MA: Harvard University Press.

Durkheim, E., 1995. Elementary Forms of Religious Life. Trans. Karen E. Fields. London: Routledge.

Fukuyama, Francis, 1995. Trust: the Social Virtues and the Creation of Prosperity. New York: Free Pess.

Giddens, Antony, 1990. The Consequences of Modernity. Cambridge: Polity Press. Hardin, Russell, 1991. Trusting Persons, Trusting Institutions. In Richard J. Zeckhauser (ed.), The Strategy of Choice. Cambridge, MA: MIT Press, pp. 185-209.

Knack, Stephen and Philip Keefer, 1997. Does Social Capital Have an Economic Payoff? A Cross-Country Investigation. The Quarterly Journal of Economics, $112(4)$, pp. 1251-1288.

Latour, Bruno, 1987. Science in action: how to follow scientists and engineers through society. Cambridge, MA: Harvard University Press.

Luhmann, Niklas, 1979. Trust and Power. New York: John Wiley.

Misztal, Barbara, 1996. Trust in Modern Societies. Cambridge: Polity Press.

Seligman, Adam, 1997. The Problem of Trust. Princeton: Princeton University Press.

Simmel, Georg, 1950. The Sociology of Georg Simmel. Trans. and ed. K.H. Wolff. New York: Free Press.

Smith, Adam, 2002 [1759]. The Theory of Moral Sentiments. Edited by Knud Haakonssen. Cambridge: Cambridge University Press.

Sztompka, Piotr, 1999. Trust: A Sociological Theory. Cambridge: Cambridge University Press.

Tabellini, Guido, 2008. The Scope of Cooperation: Values and Incentives. The Quarterly Journal of Economics, 123(3), pp. 905-950.

Uslaner, Eric, 2005. Inequality, Trust, and Civic Engagement. American Politics Research, 33, pp. 868-894.

Williamson, Oliver, 1993. Calculativeness, Trust, and Economic Organization. Journal of Law and Economics, 36(1), pp. 453-486. 



\section{Index}

aesthetics 129,183

alienation 229, 233, 242-8

from the state 82

Allard, Olivier 15-16, 32, 193, 203

Amur River 68, 76

Amur Oblast 67, 123, 230

'anti-place' 122

Arsenyev, Vladimir 66-8, 83

Asad, Talal 16o, 165, 175

avos' ('chance') 30, 179, 182-3, 192-3, 195, 198,

202-3, 244

and opportune moment $189-90$

supernatural 192

bankruptcy 56, 184, 187, 197, 201, 219

bazaars 142

Internet 236, 238, 241

as metaphor 135; see also marketplaces

Beijing 98, 209, 211, 220

belonging $89,108-9,113,172,174$

double 108; see also identity

betrayal see trust

Billé, Franck 17, 32, 101, 119, 125, 126, 140-1

Blagoveshchensk 21, 27, 76, 128, 230-1, 236, 238, 242-3

blat ('personal influence') 37, 40, 60-1

borders

associated with danger and criminality 125,

132,139

border conflicts 40, 106, 109

border trade zone $69,128,135,139$

China-Kazakh border 28

China-Mongolia border 22, 90-9

closed border zones $149-5^{\circ}$

crossing-points 19-21, 70-2

bypassing 26

closure of crossing-points 18

opening of crossing-points 90-1

history $37,40-50,66-7,123$

paired border towns 128, 199

'relocation' of 205, 209, 227-8

Russia-China border 18, 20, 40; see also

borderlands, Russia, China

Russia-Finnish border 76

Russia-Mongolia border 18, 22

US-Mexican border 54

zone of inter-civilizational contact 41, 124

borderlands 17, 41, 82, 103, 121, 139

Central Asian 188

'cleansing' of 123-4, 126

northeast Asian 16, 31

Sino-Russian 37, 42, 103-4, 244

'zone of depression' 134

Bourdieu, Pierre 149, 156, 176 brands 129, 136, 230, 235, 245, 252; see also fakes, trademarks

bribery 20, 28, 61, 81-2, 116, 220-22; see also illegal activities

brokers 20, 24-5, 27, 54, 74, 93-7; see also mediators

as 'robbers' 27

Bulag, Uradyn 130, 140

Buryats 42, 55, 125, 137

capitalism 130, 132, 143, 171-2, 174-5, 182, 192 capitalization of trust 235,238

relation with Old Belief $171-2,174$

Carey, Matthew 16, 27, 32, 183

Carrier, James 233, 248

cash 22, 76, 81, 95, 115, 185, 187, 220, 243

certification $26,79,244-5,247-8$

'cheated shareholders' 183, 187, 196-200

China

attitudes to trade 69

business in Russia 39-40, 47, 55, 60-1, 81, 197-2

construction of modernity by 130,132

decentralization 126

economic imbalance with Russia 18, 125

encouragement of small trade 18,69

excess labour $5^{8}$

geopolitical mission 133, 139

'good Chinese' 137-9

liberalization and 18

modernity of $133-4$

'New Silk Road' 88, 97

'northern hegemon' 124

President 87-9; see also traders Chinese

Chinese Eastern Railway 124, 128, 130

citizenship 23, 41, 55, 88, 109, 113

regimes 134

Communist Party

in China 28, 41, 124

in Russia 68, 108, 123-4, 153, 174

conspiracy $152,162-3$

consumer goods 70, 73, 81, 230; see also Internet; shuttle trade

contracts $11,49,50-3,56-8,175,182,187,193-7$,

201

absence of 24,74

faith as security for 173

inter-governmental 56

Corsin Jimenez, Alberto 13, 32, 37, 62, 182, 203

cosmopolitan 174

Cossacks 124, 151, 154

credit cards 236,238

criminal networks $20,37,54,136,153$

and right-wing militias 79 
cultural distance 125, 199, 206, 214, 227

cultural traditions 233

customs duties $19-20,27,72,77,96,237-8$

avoidance of 245

corruption 79

Customs Union 73

cynicism 15, 30, 79

Dasgupta, Partha 9, 11-2, 32-3, 37, 62, 75, 83, 180,203

debt $28,154,184-6$

debt peonage 67

deceit and cheating $15,44-5,48,98,101-2,110$, $116,122,131-2,135^{-} 6,138,162,168,180,196,201$

delivery of goods $238,245^{-6}, 247$ couriers 243; see also 'post service'

democracy $11,34,120,158,172$

deportation 68, 105-6, 115

Derrida, Jacques 148, 175-6

diaspora $54-5,106,113,125,155$ colonial diaspora 105

distrust 13, 23, 41-6, 131, 134, 216

in co-ethnics $53-4$

in state institutions $60,66,74-8,82-3$

in strangers 181

not same as absence of trust 194

overcoming distrust $51^{-2}, 135^{-6}, 181$

'soft' 45, 52, 6o-1

theories of $14-6,38$

Donnan, Hastings 41

doverie ('trust') 29-30, 38, 160, 213

analysis of $143^{-7}$

lack of 15,160

and nedoverie $148,167-8,231$

drugs 26-7, 80

Dyatlov, Victor 40, 55, 62, 101, 119, 141

economy

agriculture 48, 92, 133

black market 211

construction 49, 50-6, 186

currency 185

decline in Russia, 18, 133, 139

as an ecology 182

'economic complementarities' 58,61

fishing $67,71,223$

gap in values $208-10$

global 66, 215, 220

offshore 224, 226; see also Internet

inflation 114,185

informal $69-83$

labour conditions 48

mining

coal 90-2

gold 217

jade 205,218

'shock-therapy' 158, 172

survival strategies 76 timber 46-8, 72

transport 87-99

used cars 71-2, 74, 77-9, 106-7

wildlife products 217; see also bazaar, illegal activities, Internet, market

economic dispositions 188-9

emotion 183, 185, 195, 213, 215, 227, 232

enemy $41,81,173$

class 163

entrepreneur 22, 24, 58-9, 61, 74, 122, 129, 137,

171, 230-1, 235, 245

'entrepreneurial peoples' 174

ethnic $55,108,134,138$

foreign 74

ethics 29-30, 122, 143, 161, 232

ethic of trust $173-4$

work ethic 171 ; see also Protestant ethic

ethnic tension $37,40,42-6,60,67-8,81,102,110$

boundaries 116-7

clashes 46-7

exploitation

of Chinese migrant labour 53-4, 59

of indigenous peoples 67

sexual 54

Evenki 126-7, 205-6, 208-9

business $216-26$

fakes $23,26,127,134,211-3,230,236,245$

fake tourism 237

fear $78,124,138-9,180$

of Chinese immigration 18,62

of economic might of China 140

of lack of order 135

of loss 136-7

of police 78

Soviet culture of 139

of the state 79

of xenophobic attacks 23

Federal Security Bureau (FSB) 27, 80, 89, 222-4, 226

treaties 41-2

Fukuyama, Francis 11, 25, 33, 89, 98-9, 172-3, $175^{-}-6,233,249$

Gambetta, Diego 14, 33, 75, 80, 84, 207, 209, 228

Gellner, Ernest 11, 33, 103, 118-9

gift 106, 148-9, 167, 175, 214 generalized exchange $155^{-6}$ 'gifts' (bribes) 93

governmentalism 192

Graeber, David 192, 203

guanxi ('useful contacts') 29, 31, 37, 39-40, 56, 6o-1

Harbin 101, 126, 130

Hardin, Russell 14, 33, 89, 99, 180, 183, 194, 203, 232

Hart, Keith 76,84 
Hawley, Katherine 9, 33, 194-5, 203

Heihe 21, 27, 69, 76, 128, 230, 236-8, 246

hierarchy 205,228

cultural 126, 133

ethnic 116-7

in Orthodox church 43, 127, 146, 151

power structures 208

Holzlehner, Tobias 12, 17, 20-1, 26, 28-9, 133, 141, 216

honesty $15,39,74-5,187$

hope $30-1,53,94,192,195$

loss of 101, 115, 119

housing $183^{-5}$

crisis in Russia 184

decision to purchase 189,194

'shared construction' schemes 186-7

Hosking, Geoffrey 9, 11, 33, 37, 61, 63

human trafficking 37, 49, 54

Humphrey, Caroline 28-30, 99, 115, 122, 134-5 $141,173,176,184,203,207$

identity $162,168,183,196$

local 126

national 25

personal 113

'us' and 'them' 132, 151, 173

illegal activities $26,55,135$

bribery $20,28,61,81-2,116,220-2$

document fraud 72, 79

'fake tourism' 237

housing scams 194-5

in Internet business $244-5$

poaching $26,72,76,156$

racketeering 206

raiding of business $221-4$

rent taking by officials 19,187

smuggling $49,71,79-80$

of jade 216

state involvement in 187, 221-4

wildlife trade 70,76 ; see also fakes, customs, drugs

Inner Mongolia 23

'bridge' role of Inner Mongolians 87-8, 96, 99,137

Internet 121, 129, 131, 224

Alibaba Group 234-5, 246

and alienation $233-4,237-8$

Amazon 230, 240

electronic commerce 229-30; 242-3

forums 131, 191, 198, 242

Russian Internet shopping company 241-2

Taobao 229-30, 233-41, 246

Irkutsk $23,46-8,119,129,131-2,188$

irrationality $232,238-40$

Islam 25

Japan $38,67,71-2,77-8,86,89,105,124,128,151$, 189,242
Kazakhstan 20, 28, 73, 114, 116

kekao ('trustworthy') 39, 51

kinship 25-6, 87-99, 233, 238-9

anda ('sworn brother') 94-5, 98

bon ('group surname') 104, 111-4, 116

Christian 166

Church as surrogate for 154

as metaphor 88

and place of origin 113

as a resource 87,101

and trade firms 24-5, 113-6, 216, 219-20

kinsmen as customers 236

Kordonskii, Simon 154, 176

Koreans 68

Chinese Koreans 101-2, 107-8, 112

deportation of 105-6, 112

North Koreans 49, 104-5, 113

Russian Koreans 102, 107, 114-5, 117

Kyakhta 34, 37, 42-4, 50, 61-2 market 45

Kyrgyz 133

traders $23-8$

language 22-4, 29, 38, 50, 53-4, 93, 95-6, 107, 136, $145^{-8}, 193,239-40,246$

Google Translator 239 and non-linguistic experience $157-8$

Latham, Kevin 15, 33

Latour, Bruno 240, 242, 249

law $26,55^{-6}, 73^{-4}, 76,82,84,111,114,195^{-8}, 201$, $206,211,217,222,225,237$

in authoritarian societies 61

currency law 24

inequality before the law 154

kinship a surrogate for ineffective law 82-3 law forbidding foreign traders in Russia 115 reliable observance of law 12,180

Ledeneva, Alena 75,85

Luhmann, Niklas 12-4, 29, 33, 75, 82, 85, 207, $228,233,249$

Manzhouli 19, 21, 23, 110-1, 121-3, 128, 139-40

'city of trust and friendship' 129-31

negative Russian view 122, 131, 134

market 131, 139, 171-2, 191

logic of 127,182

market-places

as 'bazaar' 134

'Chinese' 23, 107, 113-5

decline of $117-8$

Cherkizovsky 8

Internet 235

Marsden, Magnus 24, 33

Martin, Dominic 11, 29, 32, 39

mediators 10, 47, 49, 55, 92-9, 121, 137, 217 examples 238-42; see also brokers Inner Mongolian case-study 93-97 in Internet business 229, 235-6, 238 
memory $46,130,132,161,202$

migration 18,69

Chinese labour migrants in Russia 18,46 , $50,56-8$

Federal Immigration Service (Russia) 48

illegal 37, 125, 135

Korean farmers in China and Russia 104-5, 112

migrant labour 24, 49, 115, 197

quotas 18-9, 48-9

of refugees 124, 126, 132

Russian migrants in China 126-7

mistrust 9, 15-6, 32, 163, 173, 179, 206; see also

distrust

'canny mistrust' 182

and distrust $9,16,138$

as moral stance 16

Miyazaki, Hirokazu 181, 189, 192, 204, 210, 228

mobile telephones 47, 236-9, 247

Mongolia 19, 23, 25, 87-99, 101, 124, 132, 139 well-being of 99

morality 14, 16, 25, 30, 60, 104, 108, 154, 161, 181, 193-4, 232

Christian 155

moral decline discourse 15

'moral harm' 195

moral obligation $38,39,195$

moral economy 29, 32, 109, 155-6, 175, 196

mortgage 185, 202

Morocco 16

Moscow 23, 27, 78, 80, 189, 197, 234, 243

as centre $82,134,205^{-6}, 209,223,226-8$ as enemy 81

myth 45, 124, 131-3, 140, 202

Namsaraeva, Sayana 20, 25, 29, 34, 138, 179

nationalism $60,88,158,161,174$

obligation 25, 31, 38-9, 158, 194-6, 196, 200

Oleinik, Anton 17, 32, 34, 173, 179, 204

O'Neill, Onora, 9-10, 34

opacity $210,216,221$

of contracts 193-5, 196, 202

of governments 15

of Internet trade 246

of mind 15,38

and transparency 198

of value 213

Orientalism 135

Park, Hyun-Gwi 18, 25, 34, 120, 207

patriotism 133, 135, 150-3, 156, 158, 161-2, 170, 172, 175; see also nationalism

passport 58, 237; see also visa

Peshkov, Ivan 19, 31, 110, 133, 141-2

police 27, 46-7, 59, 72, 136, 222, 225, 236-7, 247

attacks by 60

attacks on 78-9

bribery of $28,60,116$ lack of trust in 77

post-socialist society $17,80,136,140,154,169-71$, 175

postal services 236-7, 245-6; see also delivery of goods

power 27, 31, 41, 53, 82, 199, 201, 211, 221

imbalance of 40, 99, 103, 125

imperial 61, 123

personal 61

siloviki ('the powers') 200

state 103

trust in power $160,221-8$

vertical $82,156,208,227-8$

protest 10, 27, 179

against corruption 183, 196, 200

against state $28,77-8,200-1,221$

Protestant ethic $146,170-5$

Putnam, Robert 11, 25, 34

pyramid schemes $187-8$

railway $72,97,121$

Chinese Eastern 124, 128, 130

Trans-Siberian 19

real estate 114-6, 179-203, 211

receipts $243^{-7}$

Reeves, Madeleine 17, 32, 34

reliability 16, 29, 39, 41, 51, 148, 179-80, 197-9, 243

religion $43-4,123$

Hare Krishna 151, 162, 164-5

Old Belief 143-5, 151-62, 164-5, 170-4

paganism 152

Russian Orthodoxy 143, 151

remoteness 134, 216, 218

reputation $38,45,131,171,138,188,191,197-8,235$

link with trust 180

Robbins, Joel 15, 34

Rosanvallon, Pierre, 11, 34

Russia

attitudes to trade 68,133

colonialism 133, 139

economic modernization 170-1, 174

humiliation of 134

law-enforcement 12

President(s) 77, 144, 174, 183, 200, 222, 225

security of 18-19, 42, 44, 45, 81

Ryzhova, Natalia 18, 24-5, 27, 34, 76, 85, 194

secrecy $45,67,162,197,211$

secret deals 53

secret networks 26,32

selfhood 15-6, 137, 149, 168-9, 200

sexuality $17,19,47,54,132,136$

'sharia bank' 24

Shlapentokh, Vladimir 17, 34, 179, 204

Simmel, Georg 12, 34, 232, 249, $25^{2}$

sincerity 15, 31, 136, 194

sinophobia / anti-Chinese sentiment 40, 101, 108-9, 114, 119, 133, 138, 197

Smith, Adam 231-2, 249 
smuggling see 'illegality'

social networking 65,74

speculation 181, 184-5, 188-9, 191, 202, 227

spies $45,68,124,168$

Ssorin-Chaikov, Nikolai 162, 177

state, the

absence of authority 66-7, 103

avoidance of 247

'bureaucratic anxiety' 15, 193

cheating the state 75

and consumers $237-8,248$

corruption of 79

customer protection $244-5,247-8$

enforcement of contracts 11-2

lack of trust in $15,44,65-6,78$

obligation to citizens $75^{-6}$, 200-1

power 103, 226-7

raids on Evenki company 221-6

repression of Chinese markets $81,115,117$

'strategic initiatives' of 88-9

structures 116, 187, 196, 201, 206, 221-6, 237 trust in 59

Steinmüller, Hans 15, 35

suspicion $16,43-4,68,121,138,161-2,168-9,183$ suspicious community 173

taxation 48-50, 69, 72-3, 77, 123, 181, 201, 216-7, 222,245

Tilly, Charles 65-6, 83, 85

tourism 73-4, 126-9

'fake tourists' 58

tourist visas $57-8,92-3$

trade $17-28$

barter 68,75

bianjing trade 69

Chinese categories of trade 69

decline in Manzhouli 111

history of 44

illegal 26-7

jade 208-9

of labour 48-9

long-distance 19-22, 129

networks 18, 26-7, 32, 65, 219

non-professional 22, 28

regulations $21-2$

and religion 174

routes $20-1,23,26,237$

'shuttle' 21, 26-7, 73-5, 236

of 'souls' 49-50, 53,55

and trust 22, 74

trademarks 235; see also brands

traders 24

Chinese 22-3, 67, 79, 109-10, 137, 216-7

Chinese Korean 28, 102, 107, 109-10, 113-6

Kyrgyz 23-5, 28

Mongolian 22-3

Russian 22, 122; see also entrepreneurs

transaction costs 232,240

Transparency International 79 trust

absence of trust $237-8$

agnosticism about 38

and alienation 229

anthropological conception of 234

and autonomy 199, 207-8, 227-8

avoidance of speaking of 29,144

betrayal of 101-3, 116-7, 179, 194, 196, 200-1

boundaries of $53-4,151,153,160,169$

'conquering trust' 231

creating trust 45, 238; attempt to create trust 197-9

definitions of 10-1, 193-4, 207, 232-3

and democracy 144, 172

and dependency 16

and distrust 14, 38, 143-4, 148, 194, 206-7

and economic interest 101-2, 104, 117-8, 232

and ethnicity 109

etymology of $147-8$

experiential basis of $89-90,238-9$

evoking 198-9

and faith 144-5, 149, 16o-8, 170-5, 232, 239

fetishized 209

and fidelity 31

as a good 11, 15, 194

'half-trust' 14

and hope 119, 175

illegality and 26,65

and kinship 89, 94, 98-9, 103, 233, 238

lack of $42,44,65,82-3,89,144,163,181,237-8$

loss of 27,247

in machine 240

measurement of 232

mutual 52, 95

networks $65-6,83,87,98-9,207-8,242$

and places $122-3$

personal $13,65,83,202,238-40$

rational strategy of trusting $12,233,238$

and reliance 194-5, 198; see also reliability

social trust 11,17

of the state 65

systemic/generalized/public trust 11-2, 82, 199, 232

as a 'thing'/'stuff' $143-4,160$

theories of 9-11, 30-2, 193-4, 207, 231-4

trustworthiness and $30-1,56,75,194-5$

and truth 31, 168-9

value and 30-1

vocabularies of $30,38-40,144-5$; see also doverie, kekao

Ulan-Ude 23, 25, 49, 55, 133

uncertainty 12, 15, 167-8, 179-80, 186-7, 193, 202,

207, 233

interactional 181

and suspicion $15-6,183$

and trust 207, 233

United Nations 224

urbanism 130 
Urbansky, Sören 128, 142

Ussuriisk 28, 72, 102, 104, 106-7, 109, 113-9

Van Schendel, Willem 17, 35

violence $77-9,131,156,160,175,206$

inter-ethnic 46-7

monopoly of 247

state sponsored 223-4, 226

'violent entrepreneurship' 206

virtual communities 242, 248; see also Internet

visas 18-9, 23, 49, 57-8, 92-3, 115, 117, 237

Vladivostok $17,67,70,77-8,150-60,167-8,186$,

190-1, 197-9, 230
Weber, Max 146, 171-2, 174-5

Williams, Bernard 30-1, 35

Wittgenstein, Ludwig 157, 177

women 47

desirable qualities 193

traders $21,28,113-6$

Yanji 28, 106, 115-6

'Yellow Peril' 81, 123

Yurchak, Alexei 162, 177

Zabaikal'sk 19-20, 23, 26, 121

zenophobia $23,79,81,133,15^{2}$ 